

\section{GENERAL SCHEDULE OF EVENTS}

Monday, February 13

8:00 a.m.-10:00 p.m. 6:00 p.m. $-9: 00$ p.m.

Tuesday, February 14

7:30 a.m.-6:00 p.m.

9:00 a.m.-12:15 p.m.

12:15-2:15 p.m.

2:15 p.m.-5:20 p.m.

9:00 a.m. $-6: 00$ p.m.

12:00 noon
Registration WCC Registration Desk, Omni Shoreham Hotel

Icebreaker and Poster/Computer Displays Ambassador/Regency Gallery

\section{Registration WCC Registration Desk}

Talks: Introduction to Energy and the Environment Regency Ballroom

Luncheon (Secretary of the Interior BRUCE BABBITT is invited to speak)

Palladian Room (ticket is needed)

Talks: Availability and Quality of Energy Resources Regency Ballroom

Poster Sessions, Computer Displays Ambassador/Regency Gallery

Science Video Theater opens WCC Executive Room

Wednesday, February 15

7:30 a.m.-6:00 p.m.

Registration WCC Registration Desk

9:00 a.m.-12:00 noon

12:00-2:00 p.m.

Talks: En
Ballroom

Luncheon- “John Wesley Powell's 1869 Grand Canyon Expedition"

Palladian Room (ticket is needed)

2:00 p.m.-5:00 p.m.

Talks: Environmental Effects of Energy Extraction and Utilization

9:00 a.m.-6:00 p.m.

9:00 a.m.-6:00 p.m.

Regency Ballroom

6:00 p.m.

Poster Sessions, Computer Displays, Exhibits Ambassador/Regency Gallery

Science Video Theater WCC Executive Room

Close of Poster/Computer Sessions and Exhibit/Display area

Thursday, February 16

7:30 a.m.-3:30 p.m.

9:00 a.m.-11:30

11:30-1:30 p.m.

1:30-5:00 p.m.

5:00 p.m.

Registration WCC Registration Desk

Student Participation: Posters on Energy/Environmental Issues Birdcage

Walk

Lunch-Open

Panel Discussion on Energy and the Environment Regency Ballroom

Conclusion of formal sessions of Forum

Friday, February 17

8:00 a.m. $-12: 30$ p.m.

8:00 a.m.

8:45 a.m.

Tour of USGS National Center, 12201 Sunrise Valley Drive,

Reston, VA

Pick-up of participants at Omni Shoreham Hotel and stops on Capitol Hill

Arrive at USGS National Center. Groups will see a slide show and visit stops such as map printing plant, geology and water laboratories, library, cartography section, Earth Science Information Center, and Director's

Office.

11:45 a.m.

Lunch

12:30-1:00 p.m.

Alternate bus departures for D.C./Dulles Airport

Cover art. Oil and gas wells, land use, and land cover in southeastern Louisiana. Green=wetlands; blue=water; oranges and yellow=forest, agricultural land, and rangeland; rose=urban or built-up land; brown=barren. Front cover: Mississippi Delta. Back cover: New Orleans and points south. Compiled by Roland J. Viger and Christopher J. Schenk. 


\title{
ENERGY AND THE ENVIRONMENT- APPLICATION OF GEOSCIENCES TO DECISION-MAKING
}

\author{
PROGRAM AND SHORT PAPERS
}

Edited by L.M.H. Carter

TENTH V.E. MCKELVEY FORUM ON

MINERAL AND ENERGY RESOURCES, 1995 


\title{
U.S. DEPARTMENT OF THE INTERIOR BRUCE BABBITT, Secretary
}

\author{
U.S. GEOLOGICAL SURVEY
}

Gordon P. Eaton, Director

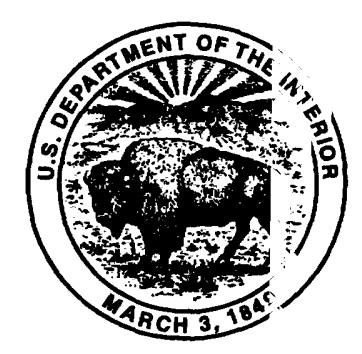

Free on application to U.S. Geological Survey, Information Services Box 25286, Federal Center

Denver, CO 80225

\begin{abstract}
Any use of trade, product, or firm names in this publication is for descriptive purposes only and does not imply endorsement by the U.S. Government
\end{abstract}

\section{Library of Congress No. 91-640066}

Organizing Committee for the 1995 McKelvey Forum:

Chair: Dudley D. Rice

Co-chairs: Timothy S. Collett, Thaddeus S. Dyman, and Richard M. Pollastro

\begin{tabular}{|c|c|c|}
\hline Program: & Logistics: & Student Participation: \\
\hline Timothy S. Collett & James D. Brewton & Laurel M. Bybell \\
\hline Robert B. Finkelman & George M. Garcia & Sharon S. Crowley \\
\hline Thomas D. Fouch & Vito F. Nuccio & Thaddeus S. Dyman \\
\hline Joseph R. Hatch & Richard M. Pollastro & Jane R. Eggleston \\
\hline Melody Holm & & Robert B. Finkelman \\
\hline Peter J. McCabe & Computer support: & Kathleen K. Krohn \\
\hline Janet K. Pitman & James D. Brewton & Eleanora I. Robbins \\
\hline Dudley D. Rice & Raymond C. Obuch & Jane B. Russell \\
\hline Richard B. Wanty & & Susan Russell-Robinson \\
\hline & Editorial: & Laure G. Wallace \\
\hline Publicity: & Lorna Carter & Susan C. Wells \\
\hline $\begin{array}{l}\text { Thaddeus S. Dyman } \\
\text { Karen J. Franczyk } \\
\text { Shirley A. Oscarson }\end{array}$ & & \\
\hline
\end{tabular}

Tour:

Jane R. Eggleston

Robert B. Finke'man

John R. Keith

Kathleen K. Krohn

Susan Russell-R obinson 


\section{FOREWORD}

Clearly, "Energy and the environment-Application of geosciences to decision-making" is a very timely topic for the Tenth McKelvey Forum. We as a Nation and as a member of the global community must consider both the increasing demand for energy and the global environmental impacts and concerns associated with energy extraction and use. We need to better understand how we can apply our knowledge about the earth sciences to the difficult decisions that lie ahead.

The U.S. Geological Survey is the Nation's premier earth science research and information agency and maintains a long tradition of providing "Earth Science in the Public Service." I know of no other agency in the world that offers the same combination of expertise in geology, hydrology, and mapping. But in this world, all that scientific expertise is not enough: To use science to solve real-world problems, we are dependent on partnerships with policy-makers and decision-makers. The USGS, a bureau of the U.S. Department of the Interior, is involved in the unbiased pursuit of earth science questions - the answers to which are an invaluable resource to the Nation. Through outreach efforts such as this forum, we are reshaping and refocusing our efforts to be even more relevant and responsive to the earth science information needs of the Nation.

As a Nation we face serious questions concerning our energy resources and the environment. Many of these ideas will be addressed by scientists from the USGS and other government agencies at this year's McKelvey Forum:

- What are the energy resources of the future?

Can we sustain or even increase our domestic oil production?

Is technology available at a reasonable price to recover sufficient quantities of natural gas?

Do we have sufficient knowledge about coal quality to justify increased usage?

- What are the environmental effects of undeveloped energy resources?

What are the conditions of natural occurrence for oil, gas, and coal?

How does their natural occurrence impact the atmosphere, water quality, and climate change?

- What are the environmental effects of energy resource development? How are the atmosphere, water quality, and the marine ecosystem affected by our increasing energy use?

How is geologic information used in formulating regulatory policy?

Basic earth science research and information from the USGS are essential in shaping policies regarding domestic and foreign energy resources, for making wise decisions about the environment, including the use of Federal lands, and for maintaining a healthy domestic energy industry. In these changing times of reengineering and downsizing of the Federal Government, we need to look at new ways to partner with others who are involved with and interested in energy and environmental issues. We need to form partnerships with other Federal and State agencies so that topical, regional, and local knowledge can be used to achieve an integrated approach in addressing important energy and

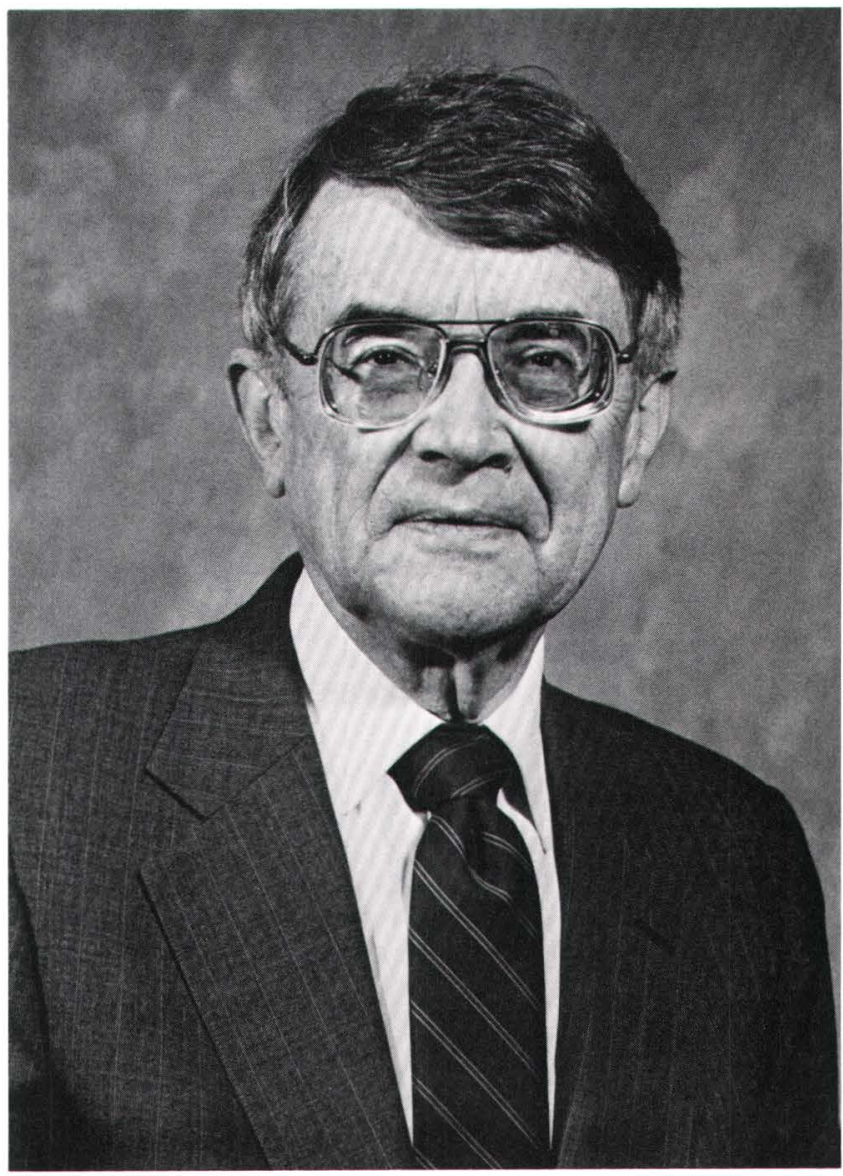
environmental issues.

The USGS is looking to increase its active partnerships with all of the Interior bureaus that are charged with regulating or managing our Nation's lands and energy and mineral resources. We also want to expand our contacts with Federal agencies beyond the boundaries of the Department and State agencies. Successful partnering will require all of us, the Federal agencies and our colleagues in the States, industry, and the academic community, to sit down and work together to ensure that we can respond to the earth science questions the American public wants answered.

We look forward to your participation in the 1995 McKelvey Forum. The exchange of ideas and information at this forum will be the foundation for those essential future partnerships.

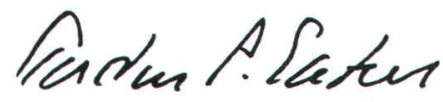

Gordon P. Eaton

Director 


\section{VINCENT E. MCKELVEY}

The McKelvey Forum honors Vincent E. McKelvey, U.S. Geological Survey geologist (1941-1978) and ninth Director (1971-1978) for his leadership of the Survey and his many contributions to understanding mineral and energy resources and the application of earth science information to public policy.

Vince started with the Survey's Strategic Minerals Program and then led a major study of the geology and phosphate resources of the Phosphoria Formation in the Rocky Mountains. The work yielded new concepts of the origin of phosphate deposits and petroleum source rock from ocean upwelling of nutrients, and also new thoughts about the relation between civilization and natural resources. He later started a program to estimate the petroleum resources of the United States. To help clarify debates on this difficult subject, he developed a method of classifying mineral reserves and resources that took into account the degrees of uncertainty both in occurrence and in economic viability. The graphical representation of this concept has been broadly applied and is widely known as the "McKelvey Box." In discussing resources, he repeatedly emphasized that although nature created mineral deposits, humans create resources. People discover deposits hidden beneath the Earth's surface, develop new uses for materials not usable before, and learn how to extract minerals from deposits once considered too deep or too lean.

Vince believed strongly that geologic knowledge should be put to good use in national affairs. Towards that end he established in the early 1970's an interdisciplinary office of earth science applications to help the Nation tackle the many problems affecting our environment.

Vince McKelvey served as an advisor on many national and international issues that involved the earth sciences-leasing policy for oil, gas, and sulfur on the outer continental shelf; national petroleum independence; and, particularly, negotiations on the

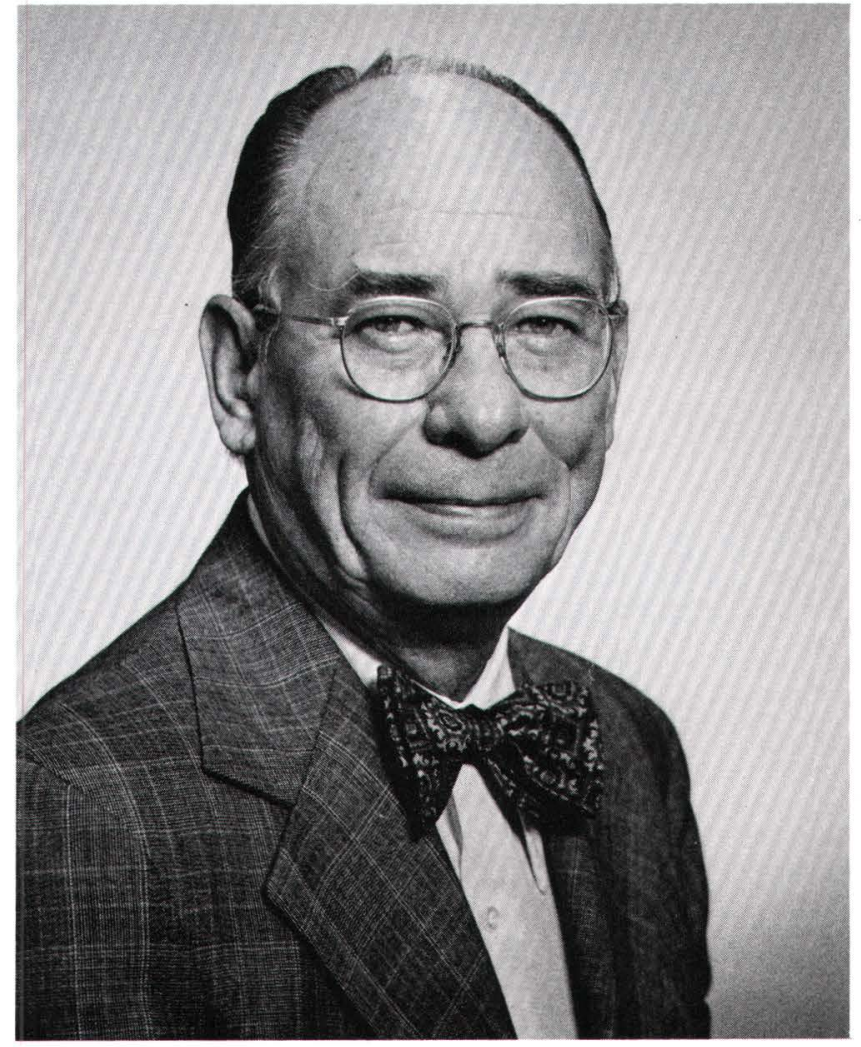

A society's wealth depends on the use it makes of raw materials, energy, and especially ingenuity.

-V.E. McKelvey Law of the Sea treaty. His great personal integrity and his dedication to objectivity made him especially effective in this role. As Director he laid down ethics guidelines for the Survey's staff and also defined and widely articulated the USGS's role as a research organization for identifying and evaluating alternatives but not advocating policy positions. 


\title{
Energy and the Environment-Application of Geosciences to Decision-Making
}

\author{
Tenth V.E. McKelvey Forum on Mineral and \\ Energy Resources, 1995
}

\author{
WASHINGTON, D.C., FEBRUARY 13-16, 1995
}

\section{PROGRAM OF LECTURES AND DISCUSSIONS}

\section{MONDAY, FEBRUARY 13, 1995}

8:00 a.m.-10:00 p.m. Registration; WCC Registration Desk, Omni Shoreham Hotel, Washington, D.C.

6:00 p.m.-9:00 p.m. Icebreaker - Ambassador/Regency Gallery

\section{TUESDAY, FEBRUARY 14, 1995}

7:30 a.m.-6:00 p.m. Registration. Note: Opening session at 9:00 a.m. in Regency Ballroom

\section{OPENING SESSION: INTRODUCTION TO} ENERGY AND THE ENVIRONMENT

9:00 a.m.

9:05

9:15

9:45

$10: 15$

$10: 45$

$11: 15$

$11: 45$

12:15 p.m.
Welcome Dudley D. Rice, U.S. Geological Survey Chief Geologist, and Robert M. Hirsch, Chief Hydrologist, U.S. Geological Survey

Program Introduction: Getting the equation right-Balancing available Earth assets against environmental consequences Gordon P. Eaton, Director, U.S. Geological Survey

What has driven the mix in U.S. energy demand-Supply and demand or regulation?

Bonnie A. McGregor and

Thomas S. Ahlbrandt

Energy resource assessments: Who cares? David W. Houseknecht

COFFEE BREAK, POSTER SESSION, COMPUTER DISPLAYS

Effects of energy utilization on the environment-Historical and future Robert M. Hirsch

Geospatial data in a digital world Nancy Tosta

Adjournment of session;

FORMAL LUNCHEON-Palladian Room (Secretary of the Interior BRUCE BABBITT is invited to speak)
Introduction John Filson, Acting

TUESDAY AFTERNOON SESSION: AVAILABILITY AND QUALITY OF ENERGY RESOURCES

2:15 p.m.

3:50

$4: 20$

5:20 p.m.

6:00 p.m.

\section{WEDNESDAY, FEBRUARY 15, 1995}

7:30 a.m. $-6: 00$ p.m. Registration

\section{WEDNESDAY MORNING SESSION: ENVIRONMENTAL EFFECTS OF NATURAL ENERGY OCCURRENCE}

$\begin{array}{ll}\text { 9:00 a.m. } & \text { Introduction J.M. McNeal, Sessior chair } \\ \text { 9:05 } & \text { Natural variations in atmospheric } \mathrm{CO}_{2}- \\ & \text { Does what we know hurt us? } \\ & \text { Eric T. Sundquist }\end{array}$


Atmospheric methane and other energyrelated trace gases-Effects on global warming and ozone Ronald S. Oremland and Keith A. Kvenvolden

10:05

12:00 noon

The paradigm of rapid climate change- $A$ current controversy Joan Fitzpatrick

COFFEE BREAK, POSTER SESSION, COMPUTER DISPLAYS, SCIENCE VIDEO THEATER

Natural radionuclides in earth, air, and water, and the effect on human health

Linda C.S. Gundersen and Zoltan Szabo

Water-quality degradation associated with natural energy sources Yousif K. Kharaka and Richard B. Wanty

Adjournment of session:

FORMAL LUNCHEON - Palladian Room "John Wesley Powell's 1869 Grand Canyon Expedition"

\section{WEDNESDAY AFTERNOON SESSION: ENVIRONMENTAL EFFECTS OF ENERGY EXTRACTION AND UTLLIZATION}

$\begin{array}{ll}\text { 2:00 p.m. } & \text { Introduction Gail Mallard, Session chair } \\ \text { 2:05 } & \begin{array}{l}\text { Our future energy use-Environmental } \\ \text { concerns beyond the year } 2000 \\ \text { Peter J. McCabe }\end{array} \\ \text { 2:35 } & \begin{array}{l}\text { Effects of energy resource development } \\ \text { on lakes-What do we need to know? } \\ \text { John T. Turk }\end{array}\end{array}$

How can geoscientists help policy makers assess the impact of energy extraction on marine ecosystems?

H.A. Karl, R.L Bermknopf, D.R. Soller, and P.S. Chavez, Jr.

$\begin{array}{ll}\text { 3:35 COFFEE BREAK, POSTER SESSION; } & \text { COMPUTER DISPLAYS, SCIENCE } \\ \text { VIDEO THEATER CONTINUE }\end{array}$

4:00 Consequences of energy use on water quality Mary Jo Baedecker, William Back, and Charles A. Cravotta, III

4:30 A little learning is a dangerous thingBut how do we apply our geoscience knowledge to the regulatory process? Lorraine H. Filipek and James K. Otton

5:00 Adjournment of oral sessions

6:00 p.m. FINAL CLOSE OF POSTER SESSION, COMPUTER DISPLAYS, AND SCIENCE VIDEO THEATER

\section{THURSDAY, FEBRUARY 16, 1995}

7:30 a.m.-3:30 p.m. Registration

9:00 a.m.-11:30 Student Participation-Pos'ers on

Energy/Environmental Issu is -

Birdcage Walk

Schools participating: McGogney

Elementary School, Washiroton, D.C.

(grades 4, 5, 6); Langston Hughes Middle

School, Reston, Va. (grades 7 \& 8);

Navajo Community Colleg?, Shiprock, $N$.

Mex.

11:30-1:30 p.m.

Lunch-Open

1:30-5:00 p.m.

Panel Discussion on Energ:' and the Environment, moderated by KEN BODE, Host of Washington Week in Review

Panel members:

-Mr. Thomas Bechtel, Director, Morgantown Energy Te hnology Center, U.S. Department of Energy

-Mr. Daniel Becker, Chief, Global Warming and Energy Program, Sierra Club

-Mr. Michael German, Senior Vice President, American Gas Association

-Gen. Richard Lawson, President, National Coal Association

-Dr. Jeremy Leggett, GREENPEACE

-Dr. Dale Nesbitt, Economist and Senior Vice President, Decision Focus, Inc.

-Dr. Nahum Schneidermann, Chevron Overseas Petroleum

-Mr. Reginal Spiller, Der'ity Assistant Secretary for Gas and Patroleum Technology, U.S. Depa-tment of Energy

3:00-3:30 COFFEE BREAK

5:00 p.m.

Conclusion of formal sessions of Tenth McKelvey Forum

\section{FRIDAY, FEBRUARY 17, 1995}

8:00 a.m.-12:30 p.m. Tour of USGS National Center, Reston, Va. 8:00 a.m. Pick-up of participants at Omni Shoreham Hotel and stops on Capitol Hill

8:45 a.m. Arrive at USGS National Center. Groups will see a slide show and risit stops such as map printing plant, geology and water laboratories, library, carto graphy section, Earth Science Information Center, and Director's Office.

11:45 a.m. Lunch

12:30-1:00 p.m.
Alternate bus departures for D.C./Dulles Airport 


\section{ENERGY AND THE ENVIRONMENT- POSTER SESSIONS}

[Contributors: American Association of State Geologists, Army Corps of Engineers, Bureau of Indian Affairs, Bureau of Land Management, Minerals Management Service, National Biological Survey, National Park Service, National Oceanographic and Atmospheric Administration, Office of Surface Mining, U.S. Bureau of Mines, U.S. Department of Energy, U.S. Environmental Protection Agency, U.S. Forest Service, U.S. Geological Survey, State Geological Agencies, and Exploration and Consulting Geologists]

[Some of these listings share poster space]

\section{USGS Energy and Environmental Program- Information Transfer}

Easy access to coal quality information: COALQUAL-

The new USGS coal quality CD-ROM database

Linda J. Bragg, Charles L Oman, Susan J. Tewalt, and

Robert B. Finkelman

CD-ROM publication of the 1995 National Assessment of Oil and Gas Resources of the United States

Ken Takahashi and Donald L. Gautier

Geological and geophysical information from the National Petroleum Reserve Alaska on CD-ROM as a tool in support of geoscientific decision-making David J. Taylor and Frederick N. Zihlman

\section{Availability and Quality of Energy Resources Domestic Conventional}

Cretaceous and Tertiary coals and coal-bearing rocks of the Western United States-A bibliography of U.S. Geological Survey data for resource estimation, quality determination, and reclamation potential evaluation Ronald H. Affolter and Joseph R. Hatch

The future of oil and gas in northern Alaska Kenneth J. Bird, Frances Cole, David G. Howell, and Leslie B. Magoon

Federal and State coal availability/recoverability studies in Eastern United States-A new approach to coal resource assessment M.D. Carter, T.J. Rohrbacher, G.A. Weisenfluh, N. Fedorko, A.G. Axon, C.G. Treworgy, H. Cetin, D.D. Teeters, R.I. Geroyan, R.S. Sites, and N.K. Gardner

Coal resource assessment in the Western United States-Factors for consideration in the management of Federal lands R.D. Hettinger, L.R.H. Biewick, Karen Bryant, M.S. Ellis, D.A. Ferderer, M.A. Kirschbaum, C.L. Molnia, LN.R. Roberts, S.B. Roberts, G.D. Stricker, and W.D. Watson

Forest planning and oil and gas resources-How they work together Melody R. Holm and John S. Dersch

Interagency cooperation for mineral leasing and operations on Federal lands Gary W. Horton
Oil in California-Quality, availability, and environmental conce 'ns Caroline M. Isaacs, Leigh C. Price, Larry A. Beyer, Kenneth J. Bird, James R. Herring, Margaret A. Keller, Paul G. Lillis, Leslie B. Magoon,

David Z. Piper, Richard G. Stanley, and Marilyn A. Tennyson

Energy studies on Native American lands funded by U.S. Department of Energy-Gas resources and sandstone reservoirs of the

Wind River Reservation, Wyoming

Ronald C. Johnson, Romeo M. Flores, and William R. Keefer

Energy resources on lands of Native Americans-Cooperative investigations by the U.S. Geological Survey, U.S. Bureau of I dian Affairs, and Tribal governments

E.A. Merewether, Bruce D. Smith, and Stephen A. Manydeeds

Conventional energy resources from the Federal Outer Continent 1 l Shelf, U.S.A.

Pulak K. Ray and George Carpenter

Energy resources and environmental issues in the U.S. Gulf Coast C.J. Schenk, R.J. Viger, and R.M. Pollastro

Energy studies on Native American lands funded by U.S. Department of Energy-Near-surface methane and hydrocarbon occurrence, Southern Ute Indian Reservation, Colorado, and Jicarilla Apache Indiar Reservation, New Mexico Robert S. Zech, Jennie L. Ridgley, Kimberley I. Cunningham, G. Michael Reimer, A. Curtis Huffman, Jr., Steven M. Condon, and Bill S. Larson

\section{Domestic Unconventional}

Resource and climate implications of natural gas hydrates William P. Dillon, James S. Booth, Timothy S. Collett, Keith A Kvenvolden, Dwight F. Coleman, Myung W. Lee, William J. Witters, and Kristen Fehlhaber

Low-permeability (tight) gas reservoirs-An environmentally acseptable major source of energy for the 21st century?

B.E. Law, C.W. Spencer, R.A. Crovelli, J.W. Schmoker, R.T. R,der, W.M. Sutherland, and K.H. Frohne

Coalbed methane-From hazard to environmental concern and untapped energy resource Dudley D. Rice, Richard B. Wanty, Charles W. Byrer, and Dina W. Kruger

\section{World Energy}

World petroleum resources Charles D. Masters

International coal-related activities of the U.S. Geological Survey and their environmental applications

John R. SanFilipo and Peter D. Warwick

\section{Environmental Effects of Natural Energy Occurrence}

Atmospheric methane flux from coals

J.L. Clayton, J.S. Leventhal, and D.D. Rice

Is increasing atmospheric $\mathrm{CO}_{2}$ really a harbinger of global warming A perspective through geologic time Charles W. Holmes 
Methane budget and global change in coastal wetlands Joel Leventhal

South Florida ecosystems studies - Geochemical history of ecosystem conditions and variability

E.C. Spiker, A.L. Bates, L.P Gough, J.R. Herring, C.W. Holmes, R.K. Kotra, H.E. Lerch, W.H. Orem, and V.C. Weintraub

Springtime emission of methane from north temperate lakes

Robert G. Striegl and Catherine M. Michmerhuizen

\section{Environmental Effects of Energy Extraction and Utilization}

The effects of oil-field brines on aquifers-Tracing the movement of brines using geochemical tools

Marvin M. Abbott

U.S. Bureau of Mines research into the environmental effects of energy resource development

T.E. Ackman, R.F. Chaiken, A.G. Kim, S.J. Schatzel, D.E. Siskind, and M.A. Trevits

Acid rain

O.P. Bricker and K.C. Rice

Energy-related selenium and vanadium contamination in San Francisco Bay, California-Effects on biological resources?

Cynthia L Brown and Samuel N. Luoma

Hydrogeology and potential of intrinsic bioremediation at a manufactured gas plant, Charleston, South Carolina

Bruce G. Campbell, Matthew D. Petkewich, James E. Landmeyer, and Francis $H$. Chapelle

The effects of oil-field brines on aquifers-Brine disposal in the East Poplar oil field, Fort Peck Indian Reservation, northeastern Montana Steven D. Craigg and Joanna N. Thamke

Potential impact of oil and gas drilling operations on Carlsbad Caverns National Park, New Mexico

Kimberley I. Cunningham, G. Michael Reimer, Harvey R. DuChene, Edward J. LaRock, Sandra L. Szarzi, and Josh M. Been

State coal resources and extraction-Impacts on the economy and environment

Heinz H. Damberger

Environmental aspects of carbonate use in energy generation Jane R. Eggleston and Robert B. Finkelman

Multi-criterion decision analysis for comparing hydropower and environmental impacts from operation of Glen Canyon Dam, northernmost Arizona

Marshall Flug

Reclaiming the scars of energy's past-Examples from the National Park Service Bruce Heise
Oil spills in Prince William Sound, Alaska

Keith A. Kvenvolden and Paul R. Carlson

Using geomorphology in mapping for oil spill planning Robert Pavia and Jacqueline Michel

Red slime, oily films, and black rocks-Sensing the iron bacteria that make neutral streams look acid

Eleanora I. Robbins, John E. Anderson, Melvin H. Podwysocki, Harry M. Edenbom, Jane R. Eggleston, Douglas Griwitz, Robert L. Kleinmann, Amold W. Norden, Margaret E. Passmore, Byron J. Prugh, Jr., Mark R. Stantom, Palmer C. Swiot, and Timothy $M$. Vandyke

Radionuclides-Energy resources and environmental h azards $R$. Randall Schumann, Sigrid Asher-Bolinder, Warren I. Finch, Linda C.S. Gundersen, James K. Otton, Douglass E. Owen, Charles T. Pierson, G. Michael Reimer, and Robert A. Zielinski

The effects of oil-field brines on aquifers-Geophysical applications in oil field environmental studies Bruce D. Smith and Aldo T. Mazzella

Environmental impacts of oil and gas pipelines H.G. Wilshire

\section{USGS-Navajo Community College Cooperative Study}

Environmental significance of New Mexico coal quality data Stephanie Begay, Suzette Martin, and Steven C. Semken

\section{PAPERS REPRESENTING PANEL MEMBERS' VIEWPOINTS}

Fossil energy technologies for the 21 st century Thomas F. Bechtel

The outlook for the natural gas industry Michael I. German

Application of geosciences to decision-making-It's ar idea worth trying and long overdue

Richard L. Lawson

Geoscientists, fossil fuels, and climate change-A defector's view Jeremy Leggett

Ten reasons why natural gas prices will not rise Dale M. Nesbitt

Global geologic and economic aspects of oil and gas resources Nahum Schneidermann

The gas and oil industry in the year 2024-A question of the road not taken Reginal W. Spiller 


\title{
Energy and the Environment- Application of Geosciences to Decision-Making
}

\author{
Program and Short Papers
}

Edited by L.M.H. Carter

\section{PAPERS RELATED TO TALKS—IN ORDER OF ORAL PRESENTATION}

\section{What Has Driven the Mix in U.S. Energy Demand- Supply and Demand or Regulation?}

\section{Bonnie A. McGregor and Thomas S. Ahlbrandt, U.S. Geological Survey, Reston, VA 22092 and Denver, CO 80225}

The Nation's fossil energy consumption and production have both more than doubled in the last 40 years reflecting the Nation's increasing need for energy resources (fig. 1). The highest level of energy consumption in the United States yet known occurred in 1993. Oil (40 percent), gas (25 percent), and coal ( 23 percent) currently account for about 88 percent of this consumption, whereas nuclear accounts for 8 percent, hydroelectric $<4$ percent, and geothermal and all other sources about 0.2 percent (EIA, 1994a). Domestic production of energy has not met domestic consumption needs for at least 30 years, and the gap is increasing (fig. 1). Among oil, gas, and coal, significant shifts in domestic energy consumption and production have taken place during the past two decades. Both coal and gas, on an energy equivalent basis, individually exceeded oil in domestic production in 1993, with coal 31 percent, natural gas 29 percent, and oil 22 percent (EIA, 1994b) (fig. 2). Net imports of oil have risen to their highest level in 15 years, and rose 15 percent from 1992 to 1993 alone (EIA, 1994b). Coal production has nearly doubled from 1970 to present (from about 600 million short tons to about 1 billion short tons produced annually). Although domestic oil and gas production has generally declined since 1970, natural gas production has increased since the mid-1980's. Natural gas is expected to $r^{\prime}$ ay an increasing domestic role in response to both environmental concerns and anticipated major contributions from "'nconventional" (or continuous-type) natural gas accumu'ations. Such continuous-type accumulations are not localiz?d into individual fields; rather they are widespread anc often involve very large volumes which require a large number of wells to develop. This paper provides a brief historical perspective particularly for the past two decades for these significant energy shifts in a complex world of changing supply, demand, policies, and regulations.

Some economists argue that industrialized societies move to increasingly efficient energy resources in a cyclic manner, moving from sources such as wood to coal to oil to natural gas and ultimately to non-carbon-based energy sources on a 100- to 200-year cycle (Nakicenovic, 1993). Other economists argue for-a much more complicated process involving demand, supply, and regulations, and argue that we actually may be moving to increased reliance on coal resources (EIA, 1994b). Domestic supplies or reserves of oil, gas, and coal, for example, are different, and their rem aining quantities are extensively debated. From figures 1 and 2, our society clearly has demanded and will continue to d?mand increasing quantities of energy if annual growth rates of real gross domestic product (GDP) of 2.2 percent (EIA, 1994b) are realized.

Due to factors such as extreme fluctuations in commodity prices, particularly oil prices, wasteful oil and ge field practices, and perceived national needs, government regulation of energy markets has been part of our history from the turn of the century. Although the United States began importing oil in 1948, the 1973 oil embargo by the OPEC 
nations strongly affected our Nation-which responded by passing legislation designed to encourage new domestic oil production by a two-tiered pricing of lower priced old oil and higher priced new oil. The desire to gain higher prices for new oil resulted in record high levels of drilling in the late 1970 's and early 1980's. Oil price deregulation during the early 1980's permitted world market forces to control oil prices, and the United States has returned to a period of reliance on OPEC oil at levels comparable to that of the early 1970's (EIA, 1994a).

Regulations have also strongly impacted natural gas supply, demand, and prices. Natural gas exploration and development have historically been secondary to oil development due to high costs and complexity of transportation and marketing of natural gas. These regulations resulted in federally regulated interstate gas pipelines but essentially unregulated intrastate pipelines. The natural gas supply shortfalls in 1977 and 1978 resulted in The Natural Gas Policy Act of 1978, which was designed to deregulate natural gas on a 10-year schedule, extend Federal regulation to all pipelines, and give incentives to certain classes of resources such as "unconventional" gas (NPC, 1992). Section 29 of the 1980 Windfall Profits Tax provided tax credits for production of coalbed methane, low-permeability reservoirs, and gas from Devonian shales. These tax credits were graduated and substantial; for example, tax credit on coalbed methane was 90 cents per MMBTU (million Btu) as compared to 52 cents per MMBTU for tight gas reservoirs by the end of 1992, when the credit was terminated. Drilling for such "Section 29" gas wells was increased during the late 1980's and early 1990's. Such wells that commenced drilling prior to January 1, 1993, in a designated low-permeability or coalbed gas reservoir, qualified for the tax credit, which remains in effect for that gas produced through the year 2003.

By contrast, coal resources are not supply-restricted domestically, but their use has environmental consequences that have strongly impacted coal development. The Power Plant and Industrial Fuel Use Act of 1978 was developed in response to perceived natural gas shortages. It prohibited switching from oil to gas and the use of oil and gas as primary fuel in newly built large power generation plants. Coal use has soared in the last two decades, but the most significant change in use reflects compliance with the Clean Air Act Amendments of 1990 (CAAA 90), which have stringent sulfur dioxide emission restrictions. Compliance has caused a shift of production from east of the Mississippi to west of the Mississippi, such that since 1988, Wyoming has been the largest coal producing State (Coal Data, 1991). Many western States have substantial coal resources, particularly low sulfur coal resources such as those in the Powder River Basin of Wyoming. Compliance with CAAA 90 gives utilities options to bring coal-fired generating units into compliance, including use of low-sulfur coals or displacement of coalfired units with either natural gas or renewable fuels. Relatively low costs of natural gas in the late 1980's and early
1990 's have resulted in conversion to natura' gas and erosion of coal's 1990 share of 53 percent of the domestic electricity generation (EIA, 1993). Clearly policy and regulations imposed by CAAA 90 and other laws impact coal quality issues and promote use of low-sulfur coal and natural gas.

A significant amount of the new nateral gas resource additions will come from "unconventional" accumulations, also called continuous-type accumulations, such as low-permeability gas reservoirs and coalbed methene. Since deregulation of the oil and gas industry in the 1980's, policy decisions have increasingly affected the energy industry, particularly encouraging use of natural gas by tax incentives such as Section 29 to produce "unconventional" hydrocarbon resources. However, there are associated costs. For example, coalbed methane is currently an important and growing natural gas resource, but on a per-I 1MBTU basis, a coalbed methane well generates 38 times th o waste water of that generated by production from a convantional onshore gas well (Lawrence and others, 1993). Similarly, the electricity generated by alternative energy sources, such as windmills near San Francisco, Calif., is three times more expensive than electricity produced by conventional fossil fuel electric generators in California (Munl; 1994).

The potential impacts of increased energy use both for coal and for natural gas will likely impact western Federal lands substantially, as major "unconventional" and conventional resources are known to exist in Wyoming, Utah, Montana, and New Mexico. For example, USG ${ }^{\wedge}$, in cooperation with DOE (U.S. Department of Energy), estimates an inplace unconventional natural gas resource in the Green River Basin in Wyoming at more than 10 time: larger than the recent USGS/MMS (Minerals Management Service) estimate of the entire recoverable conventional natural gas resources in the United States (Law and Spencer, 1993); however, the amount of recoverable resource is debated. The National Petroleum Council (NPC, 1992) I is estimated that most of the Nation's natural gas resources by the year 2010 will come from such unconventional resources. In many cases, these continuous-type resources are distributed over a wide area, as opposed to conventional resources, which are localized in distinct fields. The majority of conventional undiscovered oil and natural gas resourc's will likely be found on federally managed lands and waters (Dolton and others, 1990), and thus the Federal Government and their policies have increasingly played a significant role in energy development.

\section{REFERENCES}

Coal Data, 1991: National Coal Association. 1130 17th Street N.W., Washington, D.C., 94 p.

Dolton, G.L., Mast, R.F., and Crovelli, R.A., 19 N, Estimates of undiscovered conventional resources of oil and gas for federal lands, and for Indian and Native lands of th: continental United 
States: U.S. Geological Survey Open-File Report 90-705, 64 p., 2 plates.

EIA, 1993, Annual energy outlook 1993 with projections to 2010: DOE/EIA-0383(93), January 1993, 214 p.

- 1994a, International energy outlook 1994: DOE/EIA0484(94), July 1994, 79 p.

1994b, Annual energy review 1993: DOE/EIA-0384(93), July 1994,383 p.

Law, B.E., and Spencer, C.W., 1993, Gas in tight reservoirs-An emerging major source of energy, in Howell, D.G., ed., The future of energy gases: U.S. Geological Survey Professional Paper 1570 , p. 233-252.

Lawrence, A.W., Miller, J.A., Miller, D.L., and Linz, D.G., 1993, An evaluation of produced water management options in the natural gas production industry, in Proceedings, SPE/EPA Exploration and Production Environmental Conference, San Antonio, Texas, March 7-10: Society of Petroleum Engineers Paper 26004, p. 581-595.

Munk, N., 1994, Mandate power: Forbes, August 1994, p. 41-42.

Nakicenovic, N., 1993, The methane age and beyond, in Howell, D.G., ed., The future of energy gases: U.S. Geological Survey Professional Paper 1570, p. 661-676.

National Petroleum Council, 1992, The potential for natural gas in the United States: National Petroleum Council, $1625 \mathrm{~K}$ Street N.W., Washington, D.C., v. I-VI, 2002 p.

\section{Energy Resource Assessments: Who Cares?}

\author{
David W. Houseknecht, \\ U.S. Geological Survey, Reston, VA 22092
}

The American way of life is fueled by an energy mix comprising a variety of natural resources. American consumption of energy has risen steadily throughout our history, and although the proportions of energy fuels have changed through the years, the energy mix has been composed predominantly of fossil fuels (more than 90 percent in recent years). The remainder of our energy mix comprises nuclear (7 percent), hydropower, geothermal, and various renewable energy sources ( 3 percent collectively).

In the United States, energy is so dependable and so inexpensive that it has truly become a "transparent" commodity that most Americans take for granted. Only in times of crisis does the American public become acutely aware of the finite nature of energy resources and the degree to which our daily lives depend on a reliable and inexpensive supply of energy. Notable examples of such crises include the OPEC embargo of the early 1970's (blocks-long lines of cars at gas stations), Desert Shield/Storm (partly the result of our energy dependence on the Middle East), and the "closing" of Washington, D.C., and the Federal Government for entire days during the winter of 1993-94 (partly because of inadequate natural gas supply and (or) pipeline infrastructure). In truth, the transparency of our energy supply is a testament to the unparalleled success of the American energy sector.

Our Nation's energy mix is a reflection of complexly interwoven issues that can be considered in four general categories: (1) Scientific characterization of the energy resource base; (2) Technologies for energy extraction and use; (3) Economic viability of energy resources development; and (4) Social acceptability of various energy-use scenarios. These issues are seldom independent. For example, social pressures toward a cleaner environment favor increased use of renewable resources such as solar and wind power, the principles of which are scientifically well characterized; but we currently lack the technologies to make these renewable resources economically viable at scales that would significantly modify our energy mix.

Energy resource assessments provide significant input to each of these issues by providing information essential to answering several fundamental questions, including: What kinds of energy resources are present? How much of each resource is present? Where are the resources located? What is the quality of the resources? Are the resources available for development? Are the resources recoverable with current technology? Is development of the resources socially acceptable? What would be the environmental impacts if the resources were developed and used?

Historically, energy resource assessments have been conducted by a variety of public and private organizations employing a variety of methods, and they have produced a variety of results and products. Results have been used extensively as a basis for funding exploration and development programs, for planning energy transportation and processing systems, for constraining models of economic exchange among regions of the Nation and the world, for estimating utility supply and demand projections, and for strategic planning within both the private and public sectors.

The digital revolution has made it possible for energy resource assessments to have a greater impact on a variety of "downstream" applications. Results of energy resource assessments incorporated in geographic information systems (GIS) allow direct application to land-use management at virtually any scale. For example, the U.S. Geological Survey oil and gas assessment GIS includes Federal land-management boundaries, and already is being used by Federal agencies for land-use planning.

Who cares about energy resource assessments? Everyone cares, at some level. To citizens and policy makers directly involved in the energy sector and in Federal land-use management, energy resource assessments are essential tools of the trade. However, to average citizens whose direct exposure to energy is a light switch or a gasoline pump, energy resource assessments are as transparent as, but no less important than, the energy itself. 
Consumption and Production, 1949-1993

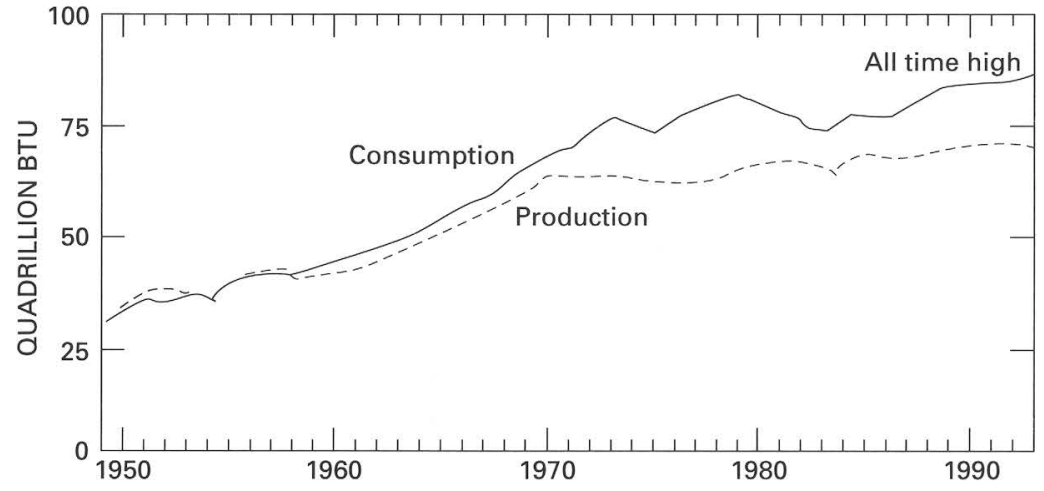

By Source, 1993

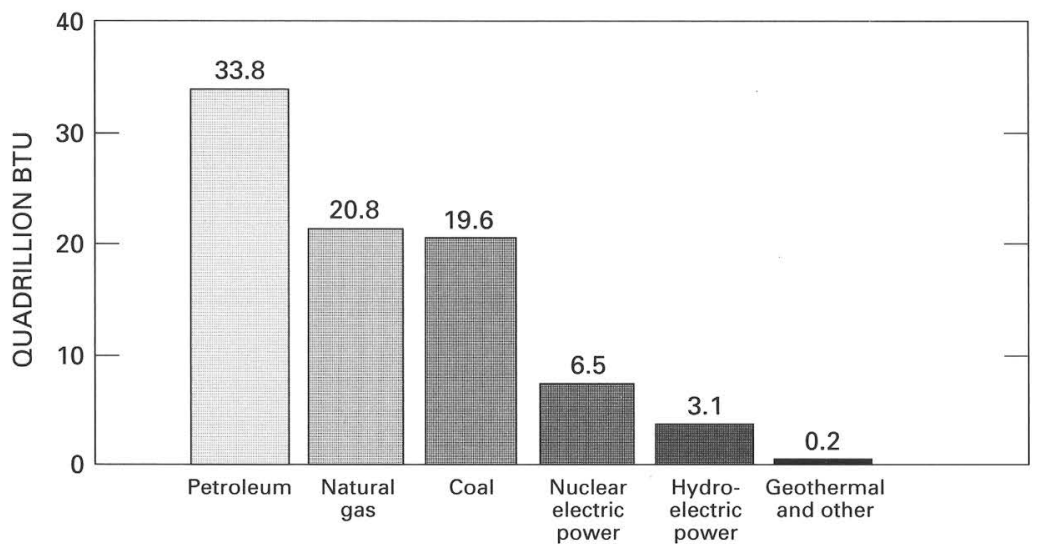

\section{By Major Source, 1949-1993}

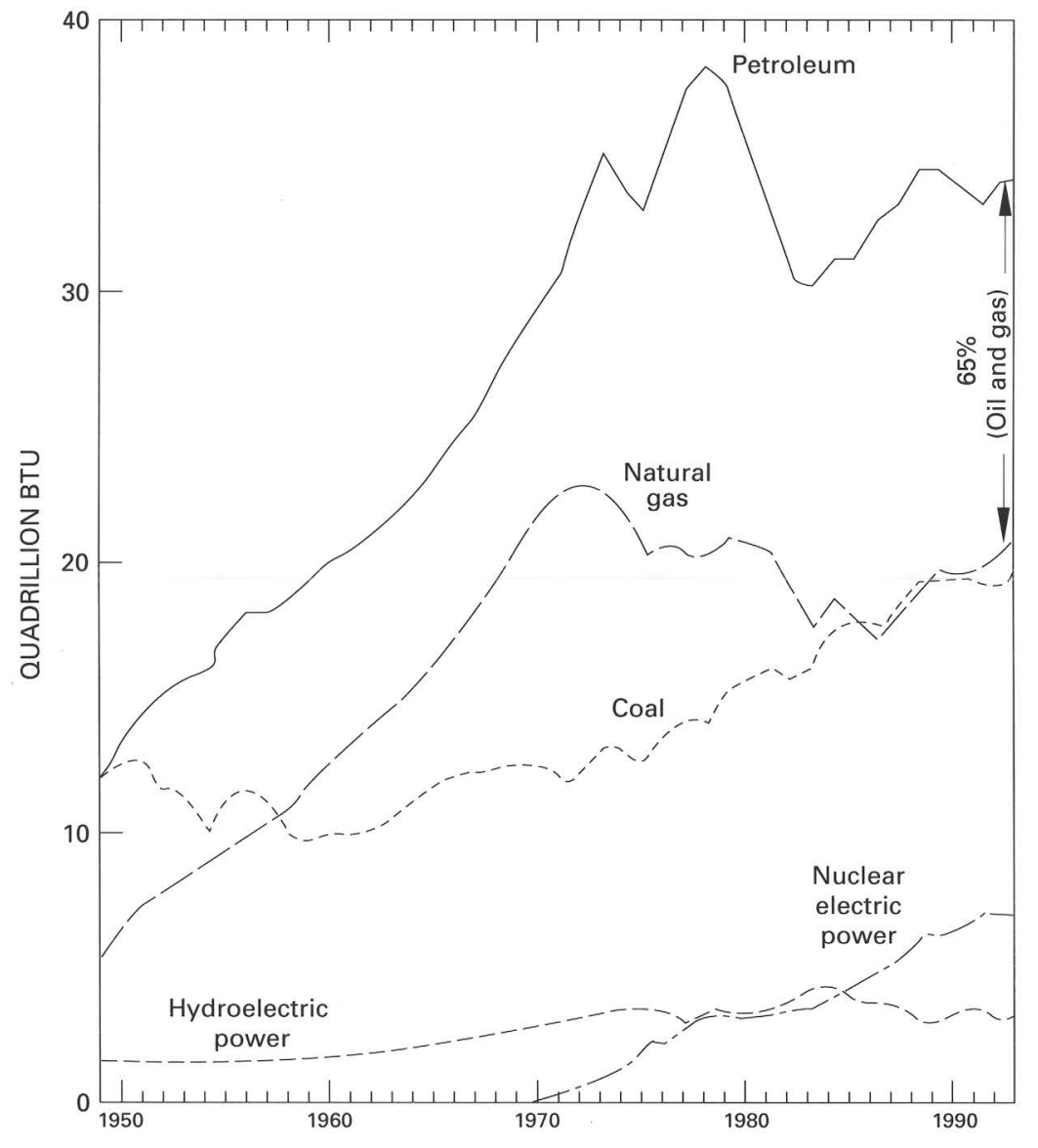

Note: Because vertical scales differ, graphs should not be compared.

Figure 1 (McGregor and Ahlbrandt). Energy consumption by source (EIA, 1994b). Note an all time high domestic consumption of energy in 1993, 65 percent of which comes from oil and natural gas. 
By Source, 1949-1993

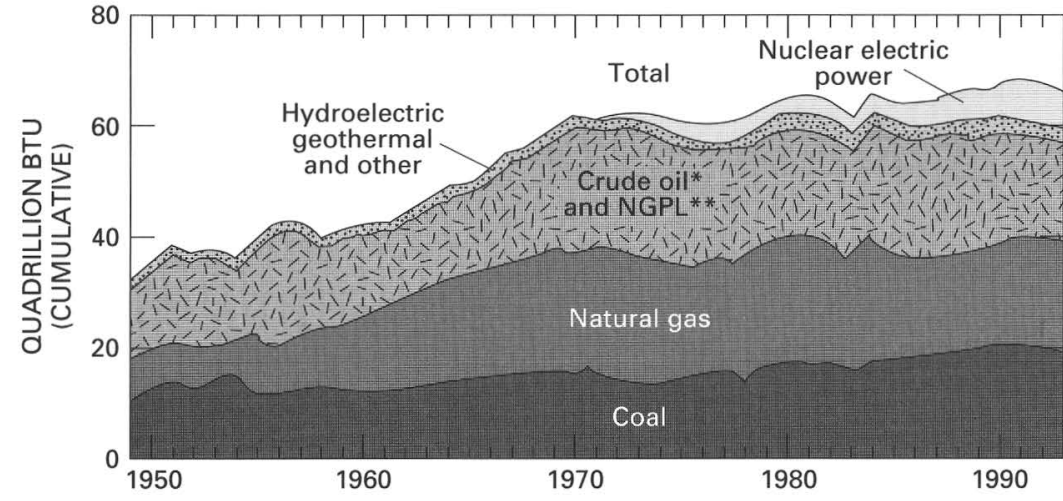

By Source, 1993

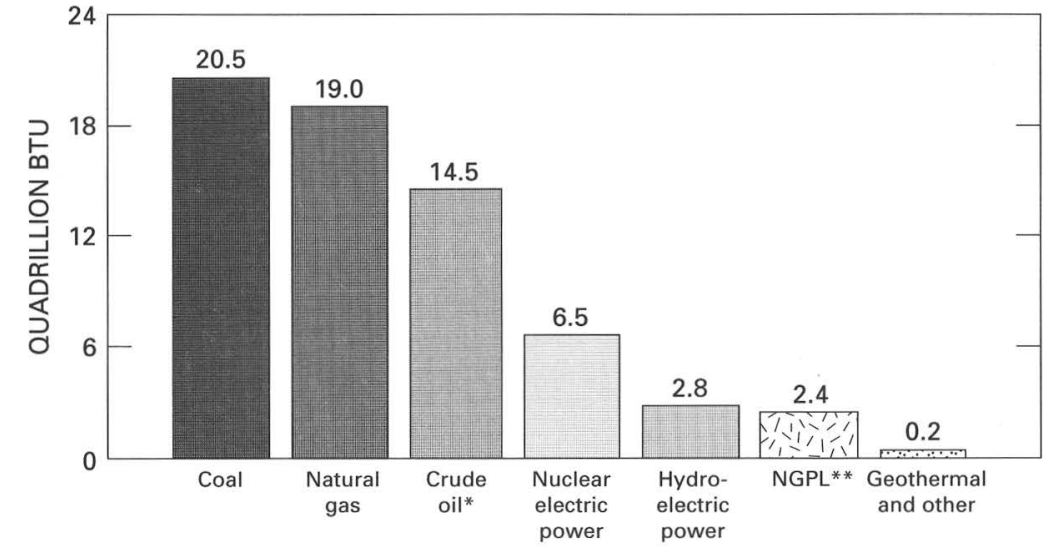

By Major Source, 1949-1993

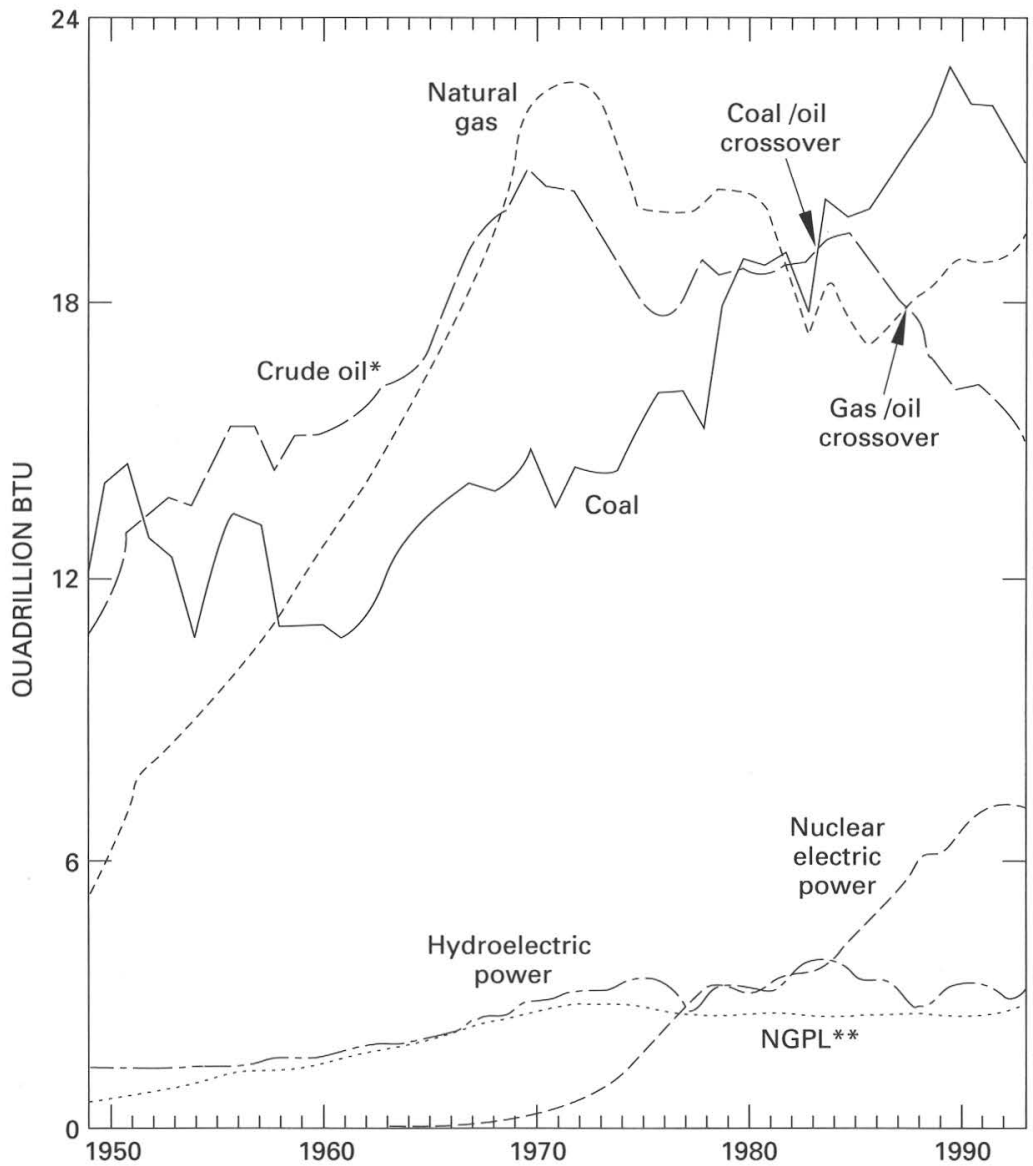

* Includes lease condensate. **Natural gas plant liquids.

Note: Because vertical scales differ, graphs should not be compared.

Figure 2 (McGregor and Ahlbrandt). Energy production by source (EIA, 1994b). Note production crossovers such that oil production on a Btu basis is less than natural gas and less than coal production. 


\section{Geospatial Data in a Digital World}

\author{
Nancy Tosta, U.S. Geological Survey, \\ Reston, VA 22092
}

Over the last decade many agencies, at all levels of government and within the private sector, have begun to use digital technology tools to manage and analyze data related to locations on the surface of the Earth. These data are referred to as geospatial data.

The recent rapid spread and growing sophistication of technologies such as geographic information systems (GIS) have led to dramatic increases in demands for digital geospatial data, as well as increasing requirements for a work force with skills in computers, networking, and digital geospatial data management. The distribution of GIS tools has also fostered an environment where digital geospatial data may be created by almost anyone, rather than under the purview of a few centralized government agencies. This trend is resulting in a multitude of data sets, which are often difficult to locate, and which, when found, may be unusable because of unknown or unacceptable quality.

Land managers and resource scientists find themselves faced with the daunting task of learning new technologies and new tools for data collection, while concurrently attempting to reorganize and integrate existing data for digital use. GIS tools are causing fundamental shifts in concepts of data organization. These technologies are not simply application tools, but systems for the organization of information based on geography. Data collected at a given location, whether map, textual, or sample data, photographs, or even specimens, can be digitally scanned or encoded. Analysis of the site where these data were collected may be done electronically, with access to all these data referenced to a common location.

As the technologies have evolved, so too have issues about data sharing, data quality, data ownership, and data access. Many institutional and technical issues are heatedly debated in public forums related to GIS and the information infrastructure.

The concept of a National Spatial Data Infrastructure (NSDI) has gained favor recently, in many ways as a vision for bringing some much needed organization to the current geospatial data confusion. The NSDI is planned as an umbrella of technologies, policies, standards, and organizations-as well as individuals-that contribute to the collection, management, distribution, and use of geospatial data. Numerous U.S. Geological Survey employees, from all Divisions, are currently participating in activities to help evolve the NSDI. The Federal Geographic Data Committee (FGDC) is charged with leading the effort to develop the NSDI and is staffed by the National Mapping Division.

Current activities within the NSDI include developing a geospatial data clearinghouse to facilitate finding and accessing data, conceptualizing and building a framework data set, and preparing standards. Aspects of the clearinghouse include use of a geospatial metadata standard for cataloging and documenting geospatial data, as well as use of Wide Area Information Servers (WAIS) and Mosaic (World Wide Web) as means for serving and searching for data on the Internet. Federal, State, and local government agencies are working to define a common digital geospatial framework data set that can serve as a foundation for additional collection and analysis of geospatial data. This effort recognizes that data requirements may vary by geography and not necessarily be consistent nationally. A variety of standards are under development to facilitate the collection, transfer, and use of geospatial data. The USGS chairs subcommittees under the FGDC with responsibilities for coordinating geologic, water, and base cartographic data.

The ability to integrate information about the environment is improving dramatically. This is the result of a proliferation of digital technology tools; more coordination in the development, maintenance, and sharing of digital geospatial data sets; and improved means to find, manage, and access geospatial data remotely and electronically. Issues that are spatial in nature, whether they be assessments of biodiversity or studies of ecosystems, infrastructure development, pollution, population growth, or the distribution and use of energy resources, can benefit from the use of digital geospatial data analysis techniques. Further, the ability to electronically plot the results of digital spatial analyses has become a powerful means for conveying information. Results of analyses can be customized as maps for more effective communication to a variety of audiences.

The future promises more capability in technology and data integration. Current research is focused on identifying options for interoperability among different data formats and databases that will allow for more efficient network management and distributed processing.

Additionally, multi-media, or the ability to integrate sound, video, and textual information with mapped data, is improving and will become common in the organization and use of environmental data. Finally, visualization and virtual reality may provide means to examine the environment and the Earth from angles never before imagined.

The challenges to improve the efficiency and use of digital geospatial data remain to be overcome. These include lack of technical knowledge, an unwillingness to adopt standards that will benefit a broad community of geospatial data users, organizational inertia, and behavioral constraints. But the value of the technology for managing and analyzing information about the Earth and its resources has been proven. It is only a matter of time before all earth science organizations recognize that digital geospatial data are indispensable to their activities. 


\section{Energy Realities of the World-}

\section{A Projected Role for Fossil Fuels}

\author{
Charles D. Masters, U.S. Geological Survey, \\ Reston, VA 22092
}

There is a lot of oil and gas in the world. Numerically, we can consider that we have already discovered sufficient resources (that is, we have Reserves-1,103 billion barrels of oil and 5,136 trillion cubic feet of gas) for more than 50 years of continuing substantial production. Of course, demand will increase to challenge any arithmetic calculation, but we have a lot of Undiscovered Resource potential to balance against the demand increase. Specifically, we believe that the Ultimate Resources of recoverable conventional oil in the world are slightly in excess of 2 trillion barrels of which we have consumed, to date, about $700 \mathrm{BB}$ (billion barrels). And, for gas, in a BTU sense, about an equal amount of resource energy exists, of which we have only used less than $1 / 2$ as much as oil, or some $300 \mathrm{BBOE}$ (billions of barrels of oil equivalent).

In a resource sense, then, we have remaining about $3 / 4$ of our oil and gas endowment (a little more of the remainder being gas rather than oil), but these resources stand against an increasingly energy-hungry world seemingly determined to consume as much as it can as quickly as it can. This means that the number of decades of dominant fossil fuel use ahead of us may be less than the history of petroleum energy use and discovery that is behind us. Though $3 / 4$ of petroleum resource production remains ahead of us, only about $1 / 3$ of Ultimate Resources remain Undiscovered, presenting us now with a rather comprehensive understanding of resource occurrence and quantity for these remaining years of consumption.

Perhaps the most important realization from our studies was the early recognition that, for oil, the Middle East is unique; and that, for gas, only one other basin has comparable resources-West Siberia Basin and the Kara Sea extension. This limiting expectation permits us to hypothesize that the quantitative distribution of world petroleum is established, though we must acknowledge a clearer perception for oil resources than for gas. The gas data are much less complete than those of oil because of the lesser market activity of gas, and as such is somewhat short on Resource credits. We do not concur with those, however, who would go on to say that there is, perhaps, double the amount of recoverable conventional gas resource relative to oil. Most commonly, numbers of this greater dimension also include so-called Unconventional Resources of gas, which may be present in large quantities but which are dispersed and difficult to recover, leading to high costs and low rates of production. Only a few of the unconventional resources are presently in production, and that under subsidy in the United States, so we believe the resource data to be most informative if the conventional and unconventional resource values are kept separate, until such time as the existing economic and deliverability problems are resolved.

The World Energy Resources Program was estahlished about 15 years ago to address the obvious reality of increased U.S. reliance on imported energy-first oil and then gas. The understanding of world petroleum occurrence was also sought, as a measure of economic well-being, so w'e were obliged to initiate the study and evaluation of all potential petroleum basins-both large and small. Initially, we focused our attention on aggregations of data by principal countries, but we are now in the process of more specific recognition of individual basins; we have, in fact, rendered a resource judgment on all basins on the basis of Reserves and Undiscovered Resources. Clearly, only a very few basins, such as the Middle East and West Siberia, are richly endowed with oil and gas-and that fits well the statistical expectation of the occurrence of geologic resources. The fact that most of it is located in the Northern Hemisphere, however, requires explanation.

The richest oil zone occupies a latitudinal balt that includes the Middle East, North Africa, Gulf of Mexi \%, and Southeast Asia. Altogether, they account for 68 percent of the world's oil and gas. Geologically, this east-we developed under the influence of an equatorial climate, favorable to the development of source rock, of carbonate reservoirs, and of salt seals-all important to the generation and entrapment of petroleum. The surprising aspect of world petroleum occurrence is the paucity of oil and gas for'nd and expected in the Southern Hemisphere relative to the northern continents. Again, the answer would appear to relate to climate, the explanation being that the Northern Hem'sphere has significant Paleozoic oil occurrences, the geology of which was derived when the continents were in a more southerly position in Paleozoic time. The Southern Hemisphere, on the other hand, remained proximal to the south polar region until the northward continental movements began in late Mesozoic time, thus positioning the northern parts of Gondwana continents in the equatorial belt as defined by the $30^{\circ}$ latitudes. Only 4 percent of the world's oil and gas is found in the South Gondwana area, whe-eas 23 percent is located in the Boreal region to the north of the equatorial geography.

This concept of a preferred location for oil and gas resources is critical to our contention of having established the distribution of oil and gas resources. Clearly, data development has been much less in areas of fewer resources because incentive for more activity is lacking. Some would say, not enough exploration has been accomplished to determine the essential minimal occurrence of petroleum resources in the world. We might concur with the resource expectation doubt raised by the limited exploration in the Southern Hemisphere, were it not for the Realms Hypothesis (Klemme and Ulmishek, 1991), which yields a rationale for the geographic occurrence of 
petroleum. Given the hypothesis, however, and our understanding of the geology, and its consistency with the climatic limitations, we believe that the petroleum resource occurrence as currently understood well represents the geologic distribution of petroleum resource futures.

The reality obtains then that most of the world's oil is in the Middle East and that by early in the 21st century, say 2015, 50 percent of the world's oil will come from OPEC and mostly the Middle East. It is also true, though, that the largest occurrences of unconventional oil-some $600 \mathrm{BB}$, an amount equal to the reserves of the Middle East-are in the Western Hemisphere in Venezuela and in Canada. Both resource occurrences are presently being produced in modest quantities and will remain as such, because of the general low prices of world oil, until such time as a national security incentive encourages their development.

Because the origin of big natural gas most commonly is related to the same geologic elements that produce oil, the distribution of the two resources is very similar. The largest occurrences are reported in the FSU and in the Middle East, just as for oil, with North America remaining in third place. Together, the big three account for 75 percent of the estimated Ultimate Resources of conventional natural gas. The futures occurrence of natural gas is more restricted, in that the United States has produced almost half of all the gas ever produced, thus markedly reducing the futures potential in this country. The United States used to produce more than 20 TCF (trillion cubic feet)/yr of natural gas but now produces about $17 \mathrm{TCF} / \mathrm{yr}$ with steadily declining reserves and production capability. Owing to the enormous exploration and development activity in the United States, we are the only maturely developed major petroleum region in the world and are not likely, in any significant way, to reverse the reality of declining production (Riva, 1994). We have not had a discovery year in excess of 1 TCF for 30 years except for Prudhoe Bay, whose resources, for now, have no economic market.

Given USGS concepts of resource distribution and quantities, Bookout (1989) of Shell Oil Co. has presented a plan, extending into the 21st century, of possible petroleum supply and demand (fig. 1). In his view, petroleum production peaks about 2020, and within that same time frame, considering a modest growth in coal production and non-fossilfuel energy, energy demand can be essentially met. From about 2020, and out to 2100 and beyond, he considered that technology and price will add an additional $450 \mathrm{BBOE}$ to the assessed resource values, and to some degree, tar sands and oil shale will enter the market, but energy from conventional petroleum resources will decline steadily such that, by 2100 , energy from coal will exceed that from all of the other fossil fuels-unconventionals included. The energy gap between supply and demand, for which we have no planned replacement, will become reality before mid-century and will continue to grow, by the end of the century, to a dimension at least equal, at that time, to the dwindlin: supply of fossil fuels.

Such a projection, of course, does not define the future, but it does point clearly at the arithmetic of resources as compared to a Demand Scenario; and it challenges our ingenuity to meet the needs of the future through energy resource enhancement, the work of geologists and engineers, or perhaps through demand reduction, a task for us all.

\section{REFERENCES}

Bookout, J.F., 1987, Two centuries of fossil fucl energy: Episodes, v. 12 , no. 4 , p. $257-262$.

Klemme, H.D., and Ulmishek, G.F., 1991, Effective petroleum source rocks of the world; Stratigraphic distribution and controlling depositional factors: American Association of Petroleum Geologists Bulletin, v. 75, no. 12, p. 1809-1851.

Masters, C.D., Attanasi, E.D., and Root, D.H., 1994, World petroleum assessment and analysis, Proceedings of the 14th World Petroleum Congress, Stavanger, Norway, Feprint: New York, John Wiley.

Riva, J.P., 1994, Domestic natural gas, past, present, and future: CRS Report for Congress 94-504 SPR, 21 p.

\section{Oil and Gas Resources of the United States- How Much Is Left and Where Is It?}

\author{
Donald L. Gautier and Gordon L. Dolton, \\ U.S. Geological Survey, Denver, CC 80225
}

The U.S. Geological Survey (USGS), in cooperation with the Minerals Management Service (M'S 'S), has recently completed a study of the possible additions to oil and gas reserves of the United States. The USGS has responsibility for resource estimates onshore and in St te waters; since 1982, the MMS has had responsibility for resource evaluation in the Federal offshore. Although the USGS has been responsible for evaluating resources of the United States for more than one hundred years, the scope, detail, and degree of documentation make this assessment the most comprehensive and accessible such study ever attempted. Results and documentation of the assessment of potential additions to reserves have been compiled in digital format and are available in traditional hard copy summary put lications, as files on CD-ROM, and as digital data accessible via the Internet. Because the study was based upon a digital Geographic Information System (GIS), the results of t ? study, the documentation, and much historical oil and ga: information can be accessed through the GIS. For any specified land area, 


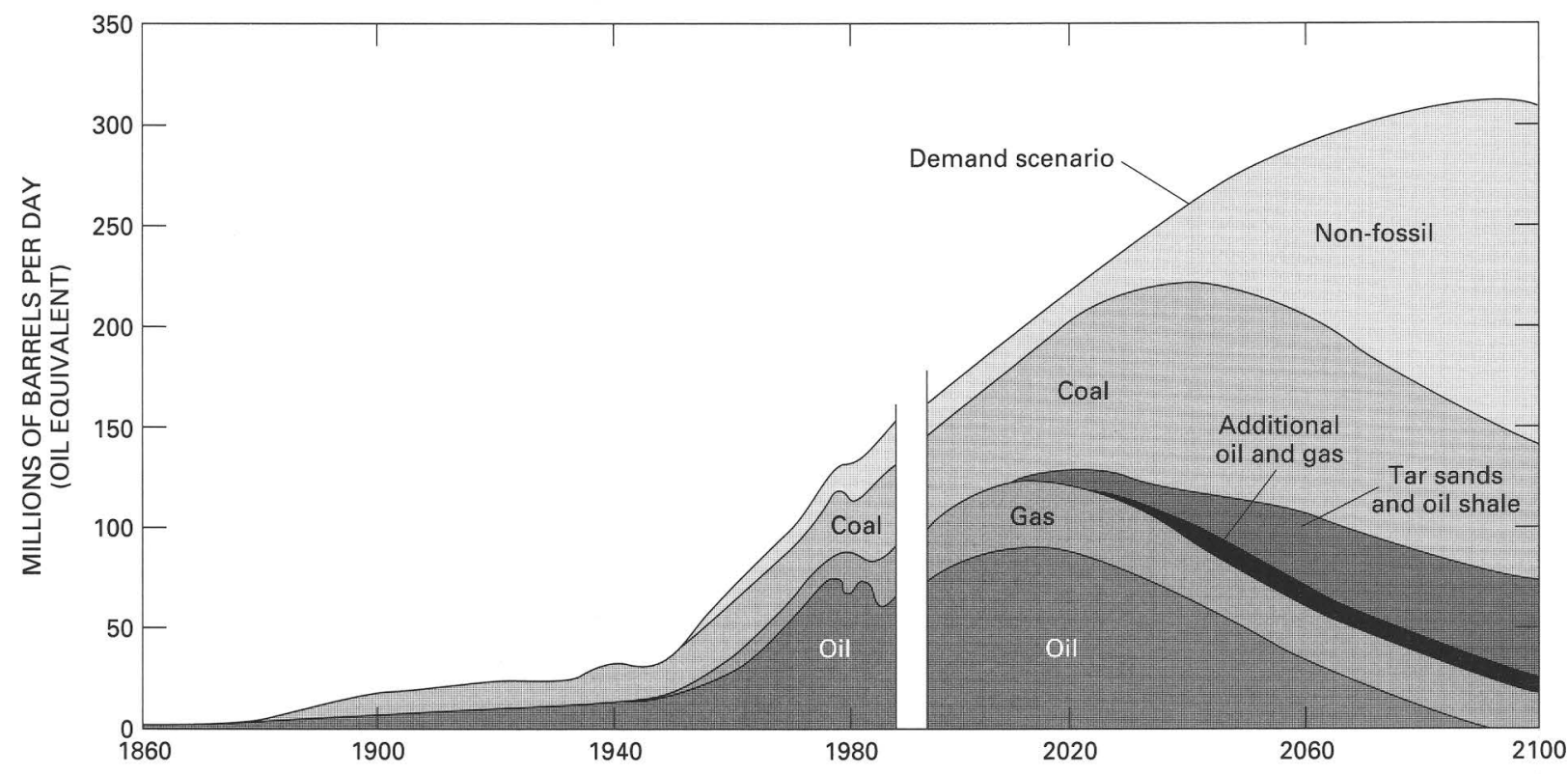

Figure 1 (Masters). Distribution of consumption of world energy resources out to 2100 , showing fossil fuel consumption declining to half of demand. Coal consumption held constant in last 40 years. Modified from Bookout (1989).

ownership, or land-use category for which a plan-view boundary can be specified, past history of oil and gas activity and possible future activity can be interpreted. This information is expected to be of considerable value to landuse planners, land-management agencies, oil and gas interests, environmental impact analysts, economists, strategic planners, and others.

Three broad categories of resources were evaluated by the USGS in this study: (1) undiscovered oil and gas in discrete pools and fields; (2) "unconventional" accumulations of oil and gas in continuous-type deposits such as gas in lowpermeability (tight) sandstones, coalbed gas, and oil or gas in self-sourced shale reservoirs; and (3) growth of reserves in fields discovered prior to the onset of this assessment project (circa 1992).

Each of these resource categories required a different assessment strategy. Undiscovered, conventional oil and gas accumulations were estimated by means of play analysis. A play, for the purposes of the National Assessment, is a set of geologically similar, known or postulated oil and (or) gas accumulations. In play analysis, geologists with local expertise combine available geologic information and concepts with historical results of exploration, discovery, and production data to estimate sizes and numbers of accumulations remaining to be found. Unconventional resources in continuous-type deposits were evaluated by means of new methodologies developed for this study, in which well-performance information from existing wells was extrapolated probabilistically to undrilled but geologically similar areas. Anticipated growth of reserves in known fields was estimated by extrapolation of growth trends observed in historical reserves data from known fields. Approximate cost curves were developed for all estimated potential additions on a region-by-region basis. Results are reported in terms of sizes, numbers, depths, and hydrocarbon type and quality of undiscovered accumulations. Unconventional accumulations are evaluated separately and reported in terms of expected estimated ultimate recoveries of wells within each play. Additions to reserves resulting from field growth are calculated on a region-by-region basis and evaluated in terms of price and supply.

Results are reported by State, by play, by province, by region, and nationally, as well as by hydrocarbon type (that is, oil and gas), field size, depth, and anticipated performance of any producing wells in the plays. Estimates have been made of the fractions of resources existing within Federal land categories. In addition to input data and analytical output, documentation consists of a series of texts describing methodologies used in assessment of various resource categories, detailed play descriptions, digital province and play maps, exploration history maps by play, and a series of graphs, tables, and charts, showing details of the exploration, discovery, and production history for each play. 


\section{Is "Unconventional" Gas a Sustainable Energy Source?}

\author{
Dudley D. Rice, Ronald C. Charpentier, \\ Thomas D. Fouch, and James W. Schmoker, \\ U.S. Geological Survey, Denver, CO 80225, and \\ Emil D. Attanasi, U.S. Geological Survey, \\ Reston, VA 22092
}

Natural gas is expected to become an increasingly important source of energy because of economic, environmental, and energy security factors. The U.S. natural gas resource base is large and diverse. Besides proved reserves considered to be producible under current economic and operating conditions, about 46 percent of the possible additions to reserves are estimated to occur in "tight" sandstones, coal beds, and shales (National Petroleum Council, 1992). These "unconventional" sources accounted for about 10 percent of the natural gas production in 1992. They are forecasted to account for 17 percent of the production in the year 2000, 22 percent in 2010, and 59 percent in 2030. The U.S. Geological Survey is currently evaluating the potential of these "unconventional" gas resources.

Until recently, "unconventional" gas was considered to be a resource of the future because its development depended on advanced technology which would require higher prices. However, because of a production tax credit (Section 29 of the Crude Oil Windfall Profits Tax Act), production has been established, major technology advances have been made, and these gas resources are now being developed. Although large resource estimates are given for "unconventional" gas, the main concerns for their sustainability are (1) recoverability constrained by price and technology, and (2) the environmental impacts of their development.

The geologic and production attributes of "unconventional" gas resources are briefly described herein and illustrated in figure 1. More details are provided in Law and Spencer (1993), Milici (1993), and Rice and others (1993). The key characteristic of this resource is that the gas generally occurs in continuous accumulations of large areal extent (fig. 1).

The largest "unconventional" gas resource potential is in low-permeability ("tight") sandstones. Permeability is the property of a rock that allows for movement of fluids. Gas accumulations in "tight" sandstones are commonly continuous and widespread and are characterized by (1) occurrence downdip from water-saturated rocks, (2) lack of obvious trap and seal, (3) crosscutting of rock boundaries, (4) abnormal pressure (high or low), and (5) close association with source rocks.

Coalbed methane also occurs in continuous, widespread accumulations which have the following properties: (1) large amounts of gas are generated in coal beds, (2) gas is stored on internal surfaces of coal, (3) gas content increases with rank and depth, (4) permeability is in fractures (cleats) and decreases with increasing depth (fig. 1B), (5) cleats are water saturated, and (6) reservoirs are abnormally pressured (high or low). Shale gas is similar to coalbed methane, but the organic matter is less concentrated in shale.

The production characteristics for "tight" gas sandstones, coal beds, and shale are similar. Gas occurs in widespread accumulations whose locations are generally known, and few holes are truly "dry." Thus the exploration risk is very low. However, production rates and ultimate recoveries for individual wells within a single accumulation are highly variable because of the heterogeneous nature of the reservoirs. For gas accumulations in "tight" sandstones, the water production rates are generally low, except in the updip transition zone to water-saturated rocks (fig. $1 A$ ). For coalbed methane and shale gas, significant amounts of water are commonly produced from wells, especially during the early stages of production.

Potential additions to gas reserves from "tight" sandstones may be as much as 250 TCF (trillion cubic feet). These resources occur in the Rocky Mountain, Gulf Coast, Midcontinent, and Appalachian areas. Production statistics are only available for those reservoirs classified as "tight" according to the Federal Energy Regulatory Commission (FERC). Many other reservoirs are also "tight," but statistics are not available. Production from "tight" reservoirs increased from $68 \mathrm{BCF}$ (billion cubic feet) in 1978 to 1,251 BCF in 1992 and accounted for about 7 percent of total production in 1991. Much of the development of gas from "tight" reservoirs was stimulated by the production tax credit, but activity has continued since its termination in 1992. Development is expected to increase in the future.

Recoverable resources of coalbed methane may be as much as $50 \mathrm{TCF}$. A major part of the resource is in the Rocky Mountain area, followed by the Eastern Interior region. Coalbed methane production has increased dramatically from about $26 \mathrm{BCF}$ in 1987 to $535 \mathrm{BCF}$ in 1992, to account for about 3 percent of the gas production. Reserves of coalbed methane increased from about 3.6 TCF in 1989 to more than $10 \mathrm{TCF}$ in 1992, to make up about 6 percent of the total. Drilling declined in 1992, prior to the end of the tax credit, because many of the more favorable areas had been developed. However, production rates continued to increase because of the long-term effects of dewatering. Dewatering reduces the reservoir pressure and allows the gas to be released from the coal matrix. New development will probably take place in the Appalachian area where (1) development has been hindered by barriers such as ownership of the gas, and (2) large amounts of methane are emitted to the atmosphere from underground mines.

Additional gas reserves from shale may be as much as $40 \mathrm{TCF}$. In 1990, the production from shale was about 0.2 TCF and is projected to increase. Most of the activity has 


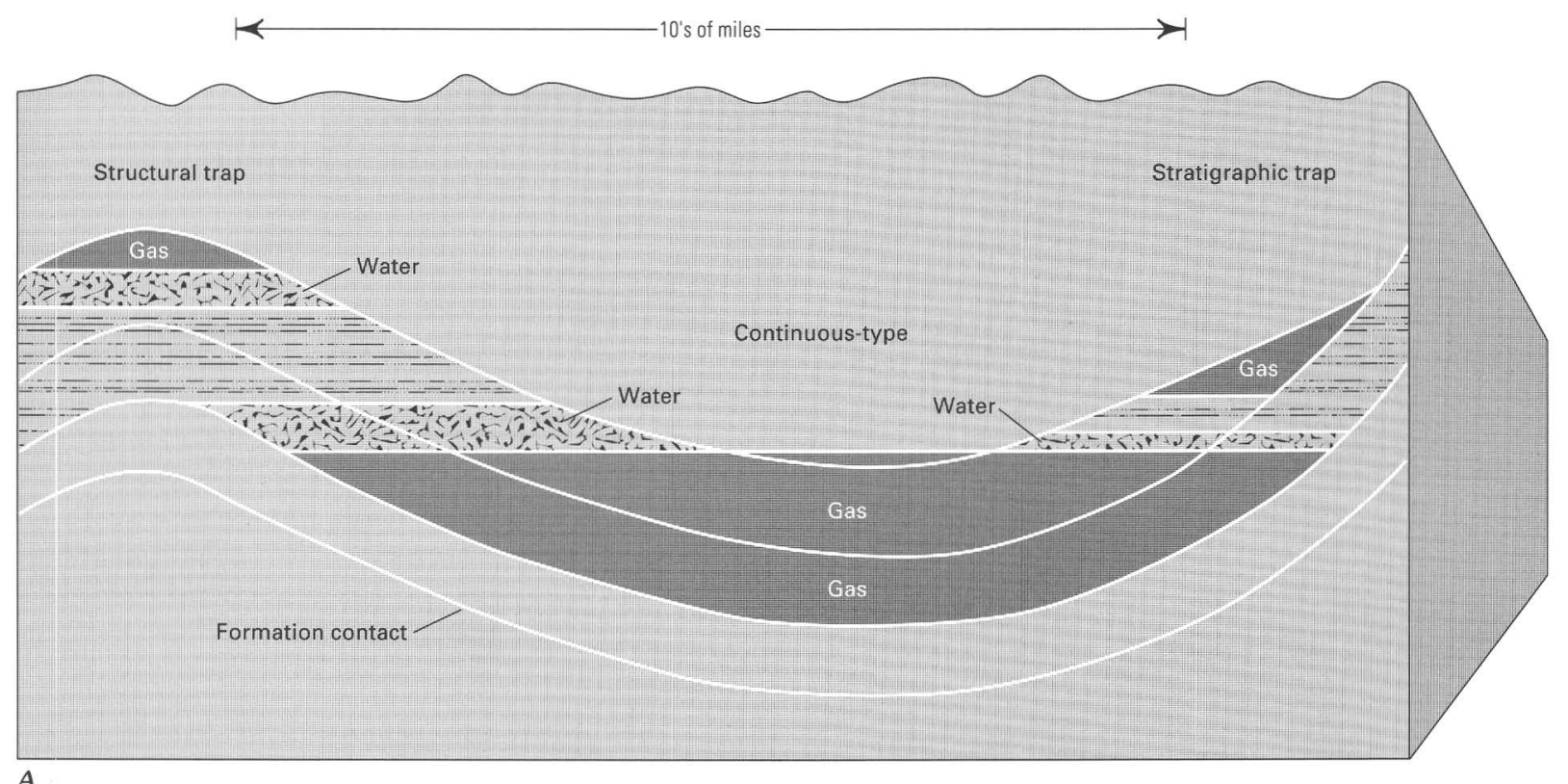

A

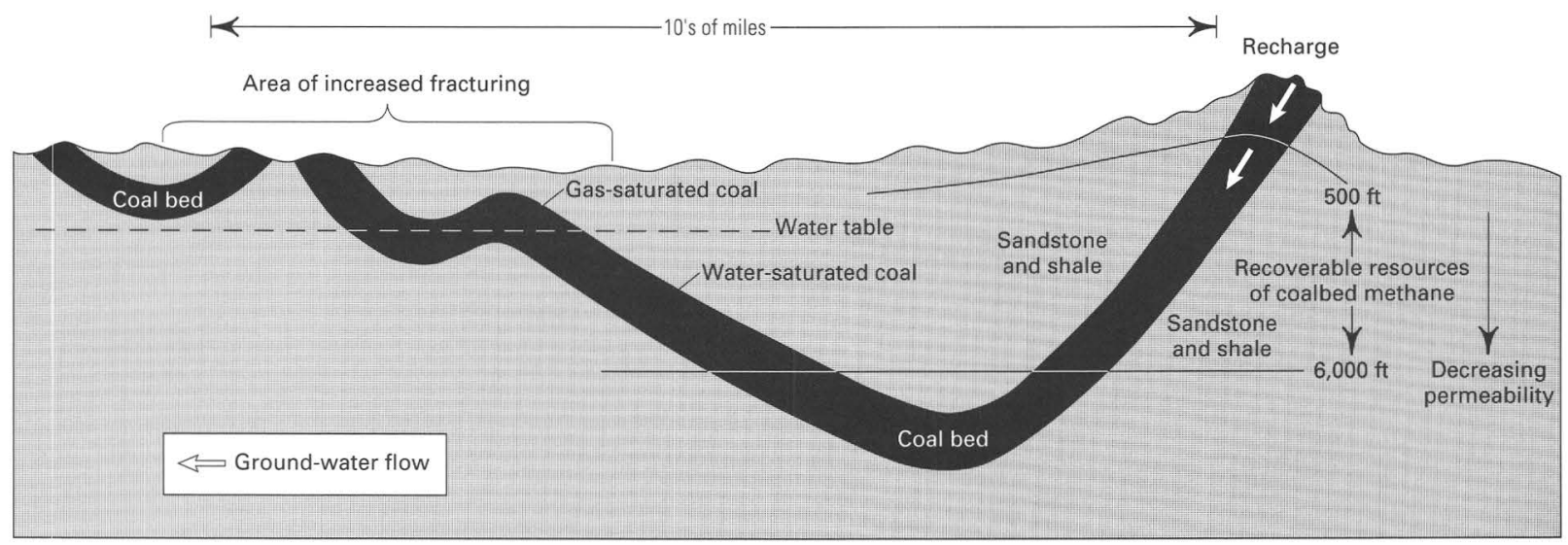

B

Figure 1 (Rice and others). Schematic diagram showing geologic setting of $A$, continuous-type "tight" gas sandstone accumulation, and $B$, coalbed methane accumulation. Shale gas accumulations are similar to those of coalbed methane.

been in Michigan and Appalachian basins, although potential exists in other basins.

Several environmental issues bear on the possible future development of "unconventional" gas resources. Because these accumulations are widespread and the reservoirs are heterogeneous, a large number (as many as tens of thousands for a single accumulation) of closely spaced wells, as well as accompanying infrastructure of roads, pipelines, and the like, will be required to develop the resource. The greatly increased human activity could adversely affect land use of private and public lands, and also decrease the quality and quantity of other resources, such as water. Such environmental concerns play a part in the Rocky Mountain area, for example, where Federal and Native American lands that may contain a significant "unconventional" gas resource are in some areas inaccessible to exploration. Another concern is water disposal, especially with coalbed methane and shale gas wells, which produce larger amounts of water than other types of oil and gas wells. Although environmentally acceptable methods of disposal are available, they are sometimes not economically feasible if large quantities are involved. On the positive side, recovery and utilization of coalbed 
methane in underground mining areas, such as the Appalachian region, would decrease atmospheric emissions of methane, a potent "greenhouse" gas, and result in both environmental and economic benefits. Finally, the contribution of natural gas from both natural geologic processes and human-related activities to "greenhouse" gases and to the global carbon cycle is not fully understood. The increased use of "unconventional" gas, resulting partly from the displacement of oil or coal, would probably affect the emissions of greenhouse gases to the atmosphere.

In conclusion, resources of "unconventional" gas are estimated to be large and to account for an increasing amount of the production in the future. However, its contribution will be strongly affected by recoverability, which is influenced by economics and technology, and by environmental issues.

\section{REFERENCES}

Law, B.E., and Spencer, C.W., 1993, Gas in tight reservoirs-An emerging major source of energy, in Howell, D.G., ed., The future of energy gases: U.S. Geological Survey Professional Paper 1570 , p. 233-252.

Milici, R.C., 1993, Autogenic gas (self sourced) from shales-An example from the Appalachian basin, in Howell, D.G., ed., The future of energy gases: U.S. Geological Survey Professional Paper 1570, p. 253-278.

National Petroleum Council, 1992, The potential for natural gas in the United States: Washington, D.C., National Petroleum Council, six volumes plus Executive Summary.

Rice, D.D., Law, B.E., and Clayton, J.L., 1993, Coalbed gas-An underdeveloped resource, in Howell, D.G., ed., The future of energy gases: U.S. Geological Survey Professional Paper 1570, p. 389-404.

\section{Assessing the Nation's Coal Resources- Is It Really a Burning Question?}

\author{
H.J. Gluskoter, U.S. Geological Survey, \\ Reston, VA 22092
}

\section{Introduction}

One of the earliest maps-if not the first-recording the occurrence of coal in North America was made by Louis Joliet and Father Jacques Marquette in 1674. They produced a map of the upper Mississippi Valley and indicated the presence of "Charbon de terre" along the Illinois River (Bement, 1929). The intrepid Frenchmen didn't discover the coal, of course; Native Americans were well aware of its existence. There is some indication that Hopi and Navajo pottery was fired in coal-heated enclosures as early as the 11th century (Lindbergh and Provorse, 1977).
For the 200 years following Joliet and Marquette's voyages of exploration, wood and some coal were used to fuel the American economy and the westward settlement of the continent. In the middle of the 19th century, railroads expanded across the continent and coal replaced wood as the dominant source of energy in the United States. By the beginning of the 20th century, more than 200 million tons of coal were consumed annually, and coal continued to be the dominant source of energy for the first half of the 1900's.

Coal no longer dominates the energy picture; the Nation's addiction to personal automobile transport and the (as yet) inability to put some form of coal into internal combustion engines have placed petroleum in the dominant position. However, the quantity of coal produced and consumed in the United States has continued to increase at a rather steady rate (fig. 1), and all projections for the next several decades are for continued increase in coal production. Current production is approximately 1 billion tons per year.

Most of the coal consumed in the United States, more than 80 percent, is used for producing electricity: approximately 55 percent of the Nation's electricity is produced in coal-fired power plants. Because the life expectancy of a power plant is in decades and no nuclear plants are currently under construction or at an advanced stage on the drawing board, coal will most likely continue to be the dominant fuel for generating electricity for the next several decades, and possibly for much longer.

\section{Coal Resource Assessments-Background}

During the first quarter of this century, when coal was the dominant source of energy in this country and the annual production of coal was rapidly rising from 200 million tons per year to more than 600 million tons per year, the U.S. Geological Survey made several estimates of the coal resources in the United States. The earliest estimate, by Campbell and Parker (1909), was a little more than 3 trillion tons of coal. The most recent national estimate of this kind was made by Averitt in 1975, and he estimated approximately 4 trillion tons, including only a very modest amount in Alaska. During the 65 years between Campbell and Parker's first publication on coal resources and Averitt's 1975 paper, at least seven other estimates of the Nation's original coal resources were published, all of which ranged from 3.1 to 4.0 trillion tons of coal.

When presented with two sets of values-(1) the total amount of coal resources in a single area, and (2) the annual production or consumption of coal in the same area-it is difficult to avoid calculating the number of years that the current production could continue before the last ton of coal is finally burned. The solution to this simple equation for U.S. coal resources has become conventional wisdom. Two examples of this conventional wisdom, pertinent to 1994-95, follow: 
"Oil and gas reserves are expected to be depleted at some point during the next century, while U.S. coal reserves amount to a 250-year supply." (National Coal Council, 1992);

"Coal is the world's most abundant fossil fuel by far. While accessible stocks of gas and oil will last 50 years or so at the rates we now exploit them, there is enough coal available for three centuries at least" (New Scientist, 1993).

\section{Coal Resources-Current Interests}

As just indicated, the total coal resources and the coal reserves are generally acknowledged both to be large and to be a significant source of energy for some time to come. If one were to recalculate the total coal resources of the Nation, the statement would remain valid, whether the new value was similar to the previous ones or if it were two to three times larger. The question then arises, what, if anything, do we as a Nation want and need to know about our coal resources?

Governments, including Federal, State, and local bodies, require resource information in making policy decisions. The Federal Government leases coal for production, and Federal and State agencies regulate mining, environmental protection, and reclamation. Local governments control land use, support industrial development, provide much of the infrastructure, and in many areas, survive on tax dollars from coal. Industry makes business decisions based on a variety of factors, and in the case of coal mining, one of these is the presence of an adequate supply of economically recoverable coal. Coal mining and utilization carry with them potentially negative environmental impacts, which are of concern to almost everybody. Because the amount of coal resources on the national scale is large, interest on coal resources shifts from the national to the regional or local scale. The program at the U.S. Geological Survey that involves assessing the Nation's coal resources attempts to respond to the more pressing of these regional concerns.

An example of increased regional studies is cooperatives between the U.S. Geological Survey and the geological agencies in the coal producing States. These studies, initiated in 1987, identify the current major constraints to the availability of coal resources for development and estimate the amount of coal available for development under those conditions. These studies are conducted within 7.5-minute quadrangles and the results can, hopefully, be extrapolated throughout the region.

These investigations, and nearly all other current coal resource efforts, make use of geographic information systems (GIS). Effective use of GIS requires all the pertinent data as well as all map products to be in digital form, allowing for updates of the resource information on a regular basis and for "real time" display of the graphical information.
At another scale, the most significant coal-producing regions (basins), and the major coal-producing beds, zones, or units will be mapped, resources calculat?d, and potential areas for future production will be indicated. Close coordination with the appropriate State geological agencies in each of the major coal basins will be raquired to conduct these studies. Factors that in the past were not commonly determined in coal assessments have ir recent years become critical with regards to potential coal utilization. These factors are grouped under the label of "coal quality" and include sulfur content, ash, rank of ccal, and coal chemistry and mineralogy. These parameters will be integrated into the basin-wide studies to whatever degree the availability of data allows.

An additional aspect of coal assessment, irrespective of scale, is the determination of federally owned coal resources. These resources are part of our Nation's energy endowment, and accurate inventory will enable balance between leasing and preservation of Federal lands underlain by coal.

\section{Conclusions}

The coal assessment program is designed to provide data to answer local and regional questions and thereby allows for more informed and, hopefully, better decisions related to coal mining and utilization. Many of the issues related to coal utilization, however, are not limited $t>$ local, regional, or national scales; rather, they are global.

As the developing countries of the world make use of the indigenous energy sources available to them, United States experience with coal exploration, coal evaluation, and coal utilization should be exported to them. The goal in assisting the developing countries is to enable them to utilize their resources efficiently and in as environmentally sound a manner as technologically possible.

\section{REFERENCES}

Averitt, Paul, 1975, Coal resources of the United States, January 1, 1974: U.S. Geological Survey Bulletin 1412, 131 p.

Bement, A., 1929, Illinois Coal: Illinois State Geological Survey Bulletin 56, $123 \mathrm{p}$.

Campbell, M.R., and Parker, E.W., 1909, Coal fields of the United States, in Papers on the conservation of mineral recources: U.S. Geological Survey Bulletin 394, p.7-26.

Lindbergh, Kristina, and Provorse, Barry, 1977, Coal-A contemporary energy story: Seattle, Wash., Scribe Publishing Company, $207 \mathrm{p}$.

National Coal Council, 1992, The near term role for coal in the future energy strategy of the United States: Arlington, ' $7 \mathrm{a}$., The National Coal Council, $76 \mathrm{p}$.

New Scientist, 1993, Why coal has a future; Where the power lies: New Scientist, no. 1857, 23 January 1993, p. 20-31. 


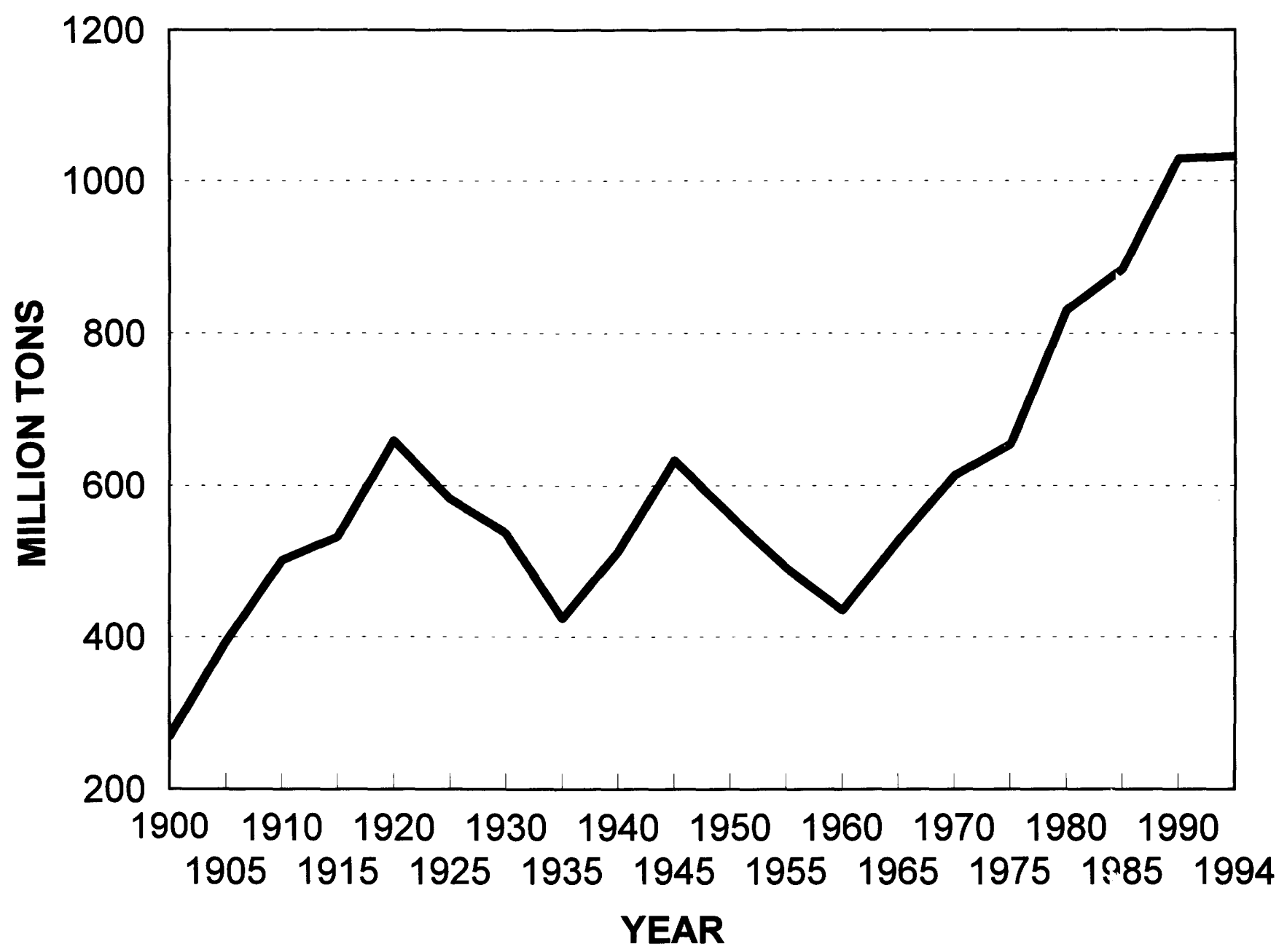

Figure 1 (Gluskoter). United States coal production (in 2,000 lb tons), 1900-1994.

\section{Coal Quality-A Clean Air Act Perspective}

\author{
Robert B. Finkelman, U.S. Geological Survey, \\ Reston, VA 22092
}

The 1990 Clean Air Act Amendments (CAAA) require that the U.S. Environmental Protection Agency (EPA) assess the impact to human health and the environment from emissions into the atmosphere from a variety of stationary sources. The CAAA cite 189 chemical substances as hazardous air pollutants (HAPS), including about 14 trace elements (antimony, arsenic, beryllium, cadmium, chromium, chlorine, cobalt, fluorine, lead, manganese, mercury, nickel, selenium, and radionuclides, such as uranium).

Coal-burning electric utility power plants are one of the primary anthropogenic sources of these trace elements. The EPA is using the U.S. Geological Survey's (USGS) coal quality data to evaluate the impact that switching from highsulfur to low-sulfur coals would have on HAPS emissions from coal-burning utility power plants and to help estimate the HAPS emissions from all major coal-burning utility boilers in the United States.

The USGS coal quality database contains information on the properties and characteristics of coal that could influence its use. Among the characteristics con'ained in the coal quality database are the concentrations of more than 60 trace elements, including all the HAPS. This information is available for more than 7,400 coal samples, inc'uding coal from all the major U.S. coal-bearing basins and from the 50 top coal-producing beds. (See also Linda Bragฐ and others' CDROM, USGS Open-File Report 94-205.)

The concern of the CAAA is with the amount of each hazardous air pollutant emitted into the atrosphere by coalburning utility power plants. The amount of the element emitted is a function of the concentration of the element in the coal and the amount of coal burned, which is a function of its heat value: To generate an equivalent amount of energy, more coal having relatively low heat values has to be burned than does coal having a higher heat value. Therefore, 
Table 1 (Finkelman). Mean input loads for HAPS (g/10 $\mathrm{Btu}$ ) and $\mathrm{SO}_{2}\left(\mathrm{lb} / 10^{6} \mathrm{Btu}\right)$ for selected coal regions.

[Data represent arithmetic mean values on an as-received basis. From Oman and Finkelman (in press)]

\begin{tabular}{lrrrrrr}
\hline & Appalachian & Eastern Interior & San Juan & Powder River & Fort Union & Gulf Coast \\
\hline No. samples & \multicolumn{1}{c}{4,227} & 263 & 174 & 484 & 278 & 112 \\
Btu/lb & 12,781 & 11,438 & 9,604 & 8,085 & 6,348 & 6,466 \\
$\mathrm{SO}_{2} \mathrm{lb}$ & 3.338 & 6.299 & 1.449 & 1.894 & 3.229 & 3.632 \\
Grams: & & & & & & \\
$\mathrm{As}$ & 1.264 & 0.790 & 0.121 & 0.274 & 0.835 & 0.344 \\
$\mathrm{Be}$ & 0.089 & .124 & .122 & .040 & .065 & .153 \\
$\mathrm{Cd}$ & .003 & .017 & .007 & .006 & .009 & .017 \\
$\mathrm{Co}$ & .252 & .281 & .158 & .117 & .177 & .366 \\
$\mathrm{Cr}$ & .604 & .672 & .304 & .368 & .456 & 1.121 \\
$\mathrm{Hg}$ & .007 & .004 & .003 & .006 & .010 & .016 \\
$\mathrm{Mn}$ & .965 & 1.665 & 2.414 & 2.788 & 5.802 & 11.306 \\
$\mathrm{Ni}$ & .593 & 1.119 & .288 & .288 & .327 & .940 \\
$\mathrm{~Pb}$ & .287 & .782 & 1.344 & .253 & .295 & .705 \\
$\mathrm{Sb}$ & .050 & .055 & .071 & .029 & .050 & .060 \\
$\mathrm{Se}$ & .124 & .115 & .092 & .052 & .057 & .398 \\
$\mathrm{U}$ & .058 & .098 & .124 & .069 & .133 & .181 \\
\hline
\end{tabular}

Table 2 (Finkelman). Probable modes of occurrence of selected trace elements in coal (Finkelman, 1993).

\begin{tabular}{ll}
\hline \multicolumn{1}{c}{ Element } & \multicolumn{1}{c}{ Modes of occurrence } \\
\hline Antimony & In pyrite and accessory sulfides. \\
Arsenic & Solid solution in pyrite. \\
Beryllium & Organic association. \\
Cadmium & Solid solution. \\
Chromium & Organic or clay association. \\
Cobalt & In pyrite and accessory sulfides. \\
Lead & Galena (PbS). \\
Manganese & Siderite (Fe,MnCO $\left.{ }_{3}\right)$. \\
Mercury & Solid solution in pyrite. \\
Nickel & Unknown. \\
Selenium & Organic association, also as PbSe in bituminous coal. \\
Uranium & Organic association, also in zircon in bituminous coal. \\
\hline
\end{tabular}

one way to properly compare the potential HAPS yield of coal would be on a grams per million Btu $\left(\mathrm{g} / 10^{6} \mathrm{Btu}\right)$ basis; this is referred to as input load. Table 1 contains information on the input loads for the average composition of coal from five major coal-producing regions. Note that these values would be modified (generally reduced) by any coal-cleaning procedure. Coal from the Appalachian basin and the Eastern Interior region commonly is cleaned; coal from the other three regions rarely is cleaned.

Another coal-quality parameter, the mode of occurrence of the element, may also influence the way that coal mining companies and utilities respond to regulations that may result from the CAAA. Information on the modes of occurrence of the HAPS in coal will enable prediction of the behavior of the elements during coal cleaning and coal combustion. This information will then allow the utilities to select the pollution control options that will help them to most efficiently meet the emission standards. Table 2 contains information on the more common modes of occurrence of the hazardous air pollutants.

\section{REFERENCES}

Finkelman, R.B., 1993, Trace and minor elements in coal, chapter 28 in Engel, M.H., and Macko, S.A., eds., Organic geochemistry: New York, Plenum Press, p. 593-607.

Oman, C.A., and Finkelman, R.B., in press, Hazardous air pollutants in major U.S. coal-producing areas: Eleventh Annual International Pittsburgh Coal Conference. 


\section{Natural Variations in Atmospheric $\mathrm{CO}_{2}-$ Does What We Know Hurt Us?}

\author{
Eric T. Sundquist, U.S. Geological Survey, \\ Woods Hole, MA 02543
}

The climatic effects of anthropogenic carbon dioxide first emerged as a prominent public policy concern during the 1970's (see, for example, National Research Council, 1977). The concern was motivated by scientific conclusions and uncertainties that have remained remarkably unchanged throughout the past two decades of intensified research. Then, as now, a doubling of atmospheric $\mathrm{CO}_{2}$ concentrations was expected to increase global mean temperatures by a few degrees during the next century. The primary sources of the added $\mathrm{CO}_{2}$ were-and still are-known to be the consumption of fossil fuels and the destruction of forests. About half of the $\mathrm{CO}_{2}$ added to the atmosphere was-and still is-known to be removed by the oceans and land plants. The expectation of global warming is based on scientific underpinnings that have withstood decades of increased knowledge, refined measurements, and vastly improved computing technology.

On the other hand, fundamental uncertainties have also persisted since the 1970's. The uncertainty of global temperatures predicted for a doubling of atmospheric $\mathrm{CO}_{2}$ remains at almost the same level. Climatic effects still cannot be predicted for specific geographic regions. Biogeochemists have argued for more than 20 years about the relative magnitude of $\mathrm{CO}_{2}$ uptake by the oceans and land plants. Given these recalcitrant uncertainties, it is not unreasonable to ask (somewhat pointedly, from a taxpayer's perspective) what we have gained from the last two decades of research on interactions among $\mathrm{CO}_{2}$, the global carbon cycle, and climate.

One conspicuous recent advance in our knowledge of atmospheric $\mathrm{CO}_{2}$ is our improved understanding of its natural variability over a broad spectrum of time scales. Expanded and improved atmospheric monitoring has revealed subtle interannual $\mathrm{CO}_{2}$ concentration changes associated with El Niño-Southern Oscillation (ENSO) events. Glacier-ice core analyses suggest that somewhat larger and slower $\mathrm{CO}_{2}$ variations may have occurred during the Middle Ages. More strikingly, the study of ice cores has shown a strong correlation between pronounced atmospheric $\mathrm{CO}_{2}$ and climate changes through the most recent glacial and interglacial oscillations of the latest Pleistocene and Holocene epochs. By inference from marine sediment records that extend farther back in time, we believe that similar $\mathrm{CO}_{2}$ and climate oscillations have probably occurred in concert for millions of years. Looking still deeper into the geologic record, we see evidence for a connection between much higher atmospheric $\mathrm{CO}_{2}$ levels and the absence of periods of continental glaciation 150 million years ago.
These conclusions contrast sharply with the prevailing opinion of 20 years ago, which held that atmosnheric $\mathrm{CO}_{2}$ was geochemically stable before human disturbance.

How does this new knowledge affert our ability to address the public's concern about the futur climatic effects of anthropogenic $\mathrm{CO}_{2}$ ? In one important way, it gives us greater confidence in the probability of global warming caused by an enhancement of the greenhouse effect. The geologic record extracted from glacier ice and marine sediments suggests that past times of higher $\mathrm{CO}_{2}$ levels were times of relatively warm climate. This simple generalization must still be tweaked and scrutinized because the evidence is indirect. Nevertheless, the geologic record appears to offer straightforward empirical support for a strong connection between increasing atmospheric $\mathrm{CO}_{2}$ le"els and global warming.

Does our new awareness of $\mathrm{CO}_{2}$ 's n`tural variability provide a basis for more authoritative pre liction of future atmospheric $\mathrm{CO}_{2}$ and climate trends? It is tempting to attribute a simple causal relationship to the geologic connections between $\mathrm{CO}_{2}$ and climate. Geologists continue to search for a "smoking gun" that would define climate's sensitivity to atmospheric $\mathrm{CO}_{2}$. Unfortunate'y, the search is repeatedly frustrated by evidence for the sensitivity of $\mathrm{CO}_{2}$ to climate, and by consideration of the many other factors that could have influenced past climates. A lthough the geologic data seem to portend global warming, they also reveal a complex tangle of interactions between climate and the global carbon cycle that was barely concivable 20 years ago. In this new view, the carbon cycle and atmospheric $\mathrm{CO}_{2}$ are just as sensitive to climate change as c'imate is to $\mathrm{CO}_{2}$. The global carbon cycle, atmospheric $\mathrm{CO}_{2}$, and the climate system must be seen as components in a single interactive system that is so complex that it exceeds the present capabilities of our most sophisticated predictive models. This important new insight means that some of our predictions must now be viewed with greater uncertainty, not less.

How do these added uncertainties affect our predictions? The record of past $\mathrm{CO}_{2}$ and climate variations highlights two particular problems that w'ere not widely recognized 20 years ago. First, any future $\varepsilon^{\prime}$ obal warming is likely to cause carbon-cycle and $\mathrm{CO}_{2}$ resnonses far more active and complex than the passive $\mathrm{CO}_{2}$ untake modeled in most current predictions. Thus, although carbon-cycle projections extending a few decades into the fi'ture can be made reliably from extrapolation of recent $\mathrm{CC}_{2}$ uptake trends, these trends become increasingly tenuous with increases in the projected likelihood and magnitude of global warming. Among the various current predictions, $t^{h} n s e$ that predict greater and sooner climatic effects must also bear the burden of greater and more immediate uncertainties due to feedbacks between climate and the carbon cycl $\%$

Second, these feedbacks extend to time scales of thousands of years and more. Figure 1 (from Sundquist, 1993) illustrates the range of time scales required for the principal 


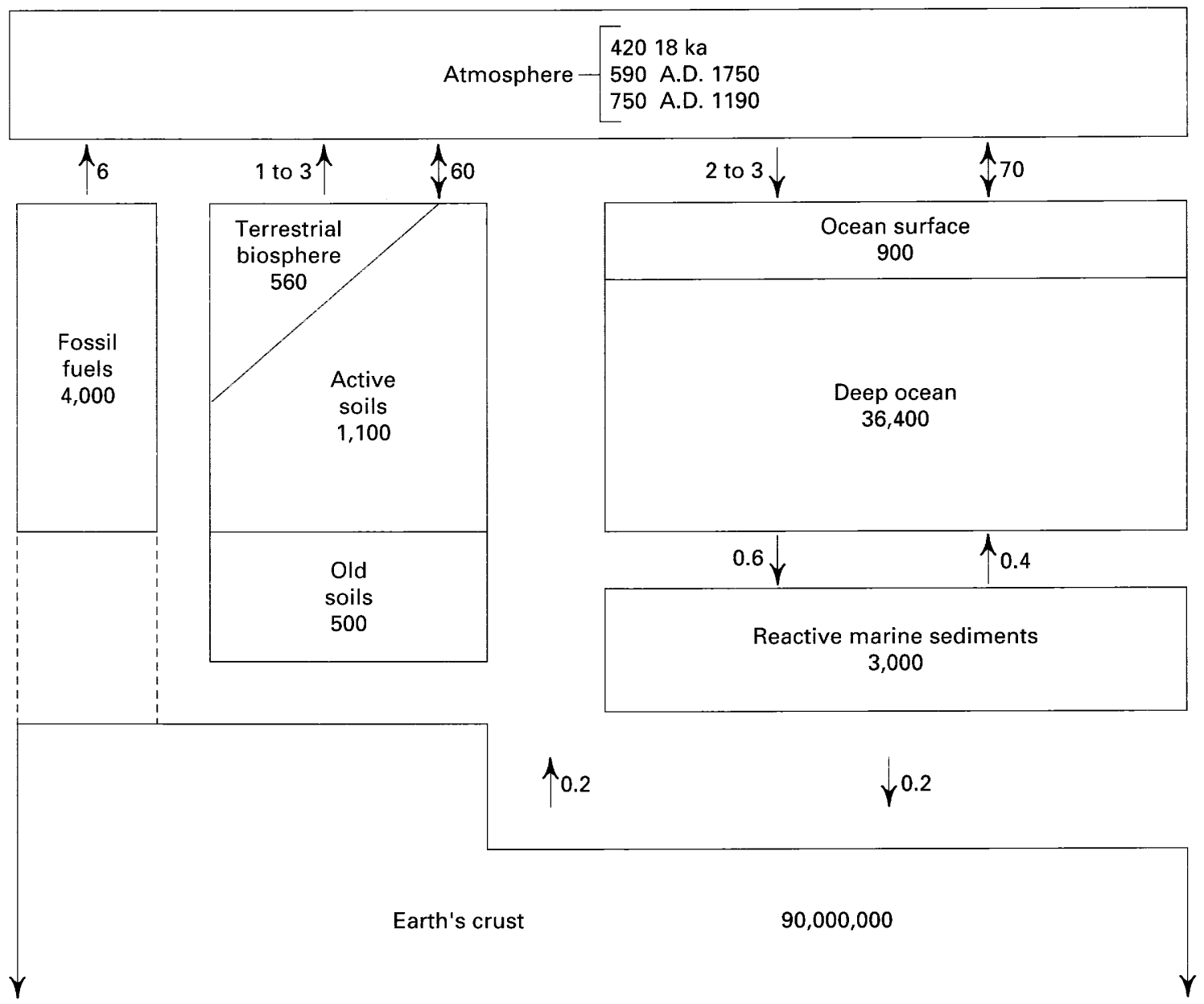

Figure 1 (Sundquist). Principal reservoirs and fluxes (arrows) in the global carbon cycle. Vertical placements relative to scale on left show approximate time scales required for reservoirs and fluxes to affect atmospheric $\mathrm{CO}_{2}$ (from Sundquist, 1993). Reservoirs: gigatons carbon. Fluxes: gigatons carbon per year.

carbon reservoirs and fluxes to affect the atmosphere. All of the natural fluxes illustrated in this figure are sensitive to climate change. Thus, anthropogenic $\mathrm{CO}_{2}$ must be viewed as a perturbation not only of the near-term atmosphere, but also of the geologic carbon-climate system. For example, the increase in atmospheric $\mathrm{CO}_{2}$ concentrations since preindustrial times is comparable to the increase that occurred over the several thousand years that marked the end of the last ice age about 10,000 years ago. These significant perturbations of the global atmosphere-while comparable in magnitude-differ greatly in mechanisms and time scales. The central lesson of this comparison is that anthropogenic $\mathrm{CO}_{2}$ must be considered a "geologic" perturbation: it affects and responds to fundamental Earth processes (particularly climatic processes) on a grand scale, it can be expected to persist for a period of time far beyond the range of typical human planning, and it will leave a conspicuous legacy in the strata of our time. Regrettably, our improved knowledge of the past does not yet enable us to foresee this legacy with much confidence.

\section{REFERENCES}

National Research Council, 1977, Energy and climate: Washir ģton, D.C., National Academy Press, 158 p.

Sundquist, E.T., 1993, The global carbon dioxide budget: Science, v. 259 , p. $934-941$.

\section{Atmospheric Methane and Other Energy-Related Trace Gases- Effects on Global Warming and Ozone}

\section{Ronald S. Oremland and Keith A. Kvenvolden, U.S. Geological Survey, Menlo Park, CA 94025}

Methane, the main component of natural gas, is an efficient energy source projected to be of increased importance to the energy budget of the United States over the next few decades (Howell and others, 1993). Methane may have 
additional value as an industrial feedstock for the production of critical organic synthesis intermediates like ethylene (Jiang and others, 1994), which would further enhance its value as petroleum reserves dwindle. Methane is a much cleaner burning fuel than oil and coal; however, release of uncombusted methane to the atmosphere does have environmental ramifications. Methane's significance in the atmosphere is twofold: its action as an absorber of reflected infrared radiation from the Earth's surface (as a "greenhouse gas") and its chemical reactions that influence the abundance of ozone in the troposphere and stratosphere. On a molecular basis, methane absorbs about 20 -fold more infrared energy than does carbon dioxide $\left(\mathrm{CO}_{2}\right)$, and because of this feature and its relatively high abundance, it is second to carbon dioxide in importance as an atmospheric greenhouse gas. The sum of all the non-carbon dioxide greenhouse gases (for example, methane, nitrous oxide, chlorofluorocarbons) is estimated to be equal to the heat-trapping properties of the carbon dioxide currently in the atmosphere, a factor that can accelerate atmospheric warming predictions by a factor of two (Dickenson and Cicerone, 1986). We briefly describe herein what is known about methane and some other key energy-related trace gases present in the atmosphere. For more detail, see Cicerone and Oremland (1988).

The globally averaged concentration of methane in the atmosphere is about 1.7 parts per million, and the total quantity in the atmosphere (atmospheric burden) is roughly $4.8 \times 10^{15}$ grams. The major mechanism by which methane is removed from the atmosphere is by an oxidative reaction sequence initiated with hydroxyl radicals ("OH"). Hydroxyl radicals are highly reactive, short-lived entities which occur in the atmosphere from the photolysis of water vapor. From measurements of the kinetics of this reaction, a residence time of methane in the atmosphere of about 10 years can be derived. Annual flux of methane to the atmosphere is calculated by dividing the atmospheric burden by the residence time, which yields a value of about $500 \times 10^{12} \mathrm{~g}$. Two factors complicate these calculations, namely the amount of methane removed from the atmosphere by methane-oxidizing bacteria in soil, and the increasing concentration of methane in the atmosphere. The oxidizing factor is not well known, perhaps accounting for between 1 and 10 percent of the total consumed (referred to as a "sink"). With regard to increasing methane concentrations, ice core data reveal that the concentration of methane has doubled in the atmosphere over the past 150 years. During the decade from 1978 to 1987, the increase was determined to be about 1 percent per year (Blake and Rowland, 1988). The amount of recent annual increase is thus roughly comparable to that annually consumed by soil bacteria. The rate of annual increase has lessened in recent years (Steele and others, 1992), perhaps because the Mt. Pinatubo eruption decreased the abundance of hydroxyl radicals, although a decrease of natural gas leakage from supply lines of the former Soviet Union may have also contributed (Dlugokencky and others, 1994).
We now review what is known abcut major sources of methane to the atmosphere, and an effort at quantification of these source terms is given in table 1 . Based on radiocarbon content, 70-90 percent of atmospheric methane is derived from carbon that has been recently in exuilibrium with the atmosphere, indicating that biological sources, rather than the radiocarbon-free geologic sources (for example, natural gas accumulations), are responsible for most of this methane. The majority of this radiocarbon-rich methane is directly attributable to the activities of the anaerc hic methane-generating bacteria present in animal gastrointestinal systems (including ruminants and termites), in natural wetlands, and in rice paddies. Human food production activity has been the major source of the methane increase over the past century-particularly biomass burning to clear new land for crops, domestic livestock herd raising, and rice production. Recovery and distribution of natural gar and the mining of coal account for only about 15 percent of the budget. Nonetheless, greater future use of both natural gas and coal will likely increase this relative proportion as well as the absolute quantity of methane derived from these nonrelated sources. The contribution of methane from natural surface gas seeps to the global budget has not been estimated, although gas seeps are common (Oremland and others, 1987; Lorenson and Kvenvolden, 1993).

Other factors contributing to future atmospheric methane increases may be related to feedbark effects of global warming releasing methane entrapped in polar permafrost (Kvenvolden and others, 1993) and in gas hydrate (Kvenvolden, 1988), as well as diminished consumption of methane from the air by soil bacterial communities that serve as sinks (Steudler and others, 1989). The magnitude of these future hypothesized sources and dimini hed sinks can only be guessed at, which adds a distressing degree of uncertainty to any predictions.

On the question of ozone, methan: is generally a net producer of pollutant ozone in the troposphere, whereas in the stratosphere it can actually help protect the integrity of the ozone layer. In the troposphere where nitrogen oxides are also abundant, especially in urban locations, the following ozone-generating reaction occurs as initiated with energy derived from sunlight (" $h v ")$ :

$$
\left.\mathrm{CH}_{4}+4 \mathrm{O}_{2}+2 \mathrm{hv} \longrightarrow \mathrm{CH}_{2} \mathrm{O}\right\lrcorner \mathrm{H}_{2} \mathrm{O}+2 \mathrm{O}_{3}
$$

About $60 \times 10^{12} \mathrm{~g}$ of methane annually escapes oxidation in the troposphere and migrates up to the stratosphere. Methane in the stratosphere can undergo reaction with ozone-destroying chlorine atoms to form a temporary reservoir of inactive hydrochloric acid molecules:

$$
\mathrm{CH}_{4}+\mathrm{Cl} \longrightarrow \mathrm{CH}_{2}+\mathrm{HCl}
$$

Hence reaction 1 forms tropospheric ozone, an undesirable gas because of its ability to form smog and impair the health of animals and plants. In contrast, reaction 2 is 
environmentally beneficial because it tends to confer a degree of protection to the stratospheric ozone layer. Other halocarbon gases derived from human activities, such as chlorofluorocarbons (CFCs), methyl halides (such as $\mathrm{CH}_{3} \mathrm{Br}$ ), halons, and hydrochlorofluorocarbons (HCFCs), all contribute to the stratospheric abundance of chlorine and bromine atoms, both of which destroy ozone as follows:

$$
\begin{aligned}
& \mathrm{Cl}+\mathrm{O}_{3} \longrightarrow \mathrm{ClO}+\mathrm{O}_{2} \\
& \mathrm{Br}+\mathrm{O}_{3} \longrightarrow \mathrm{BrO}+\mathrm{O}_{2} \\
& \mathrm{ClO}+\mathrm{BrO} \longrightarrow \mathrm{Cl}+\mathrm{Br}+\mathrm{O}_{2}
\end{aligned}
$$

Reaction 5 catalytically regenerates the ozone-destroying halogen atoms, and may be an important factor in the formation of the stratospheric ozone "hole" over the Antarctic continent. Although these halocarbons are not strictly speaking energy-related gases, their use is characteristic of an industrial society reliant on abundant energy usage. Their future employment will be regulated or ended by international agreements like the Montreal Protocol and its addenda. Some of these gases may be destroyed by soil bacteria, although the global significance of these reactions is not known.

Figure 1 qualitatively illustrates some of the gases, in addition to methane, which contribute to global warming and which are ozone-reactive. Hydrofluorocarbons (HFCs) have been proposed to replace CFCs, but some of them, such as

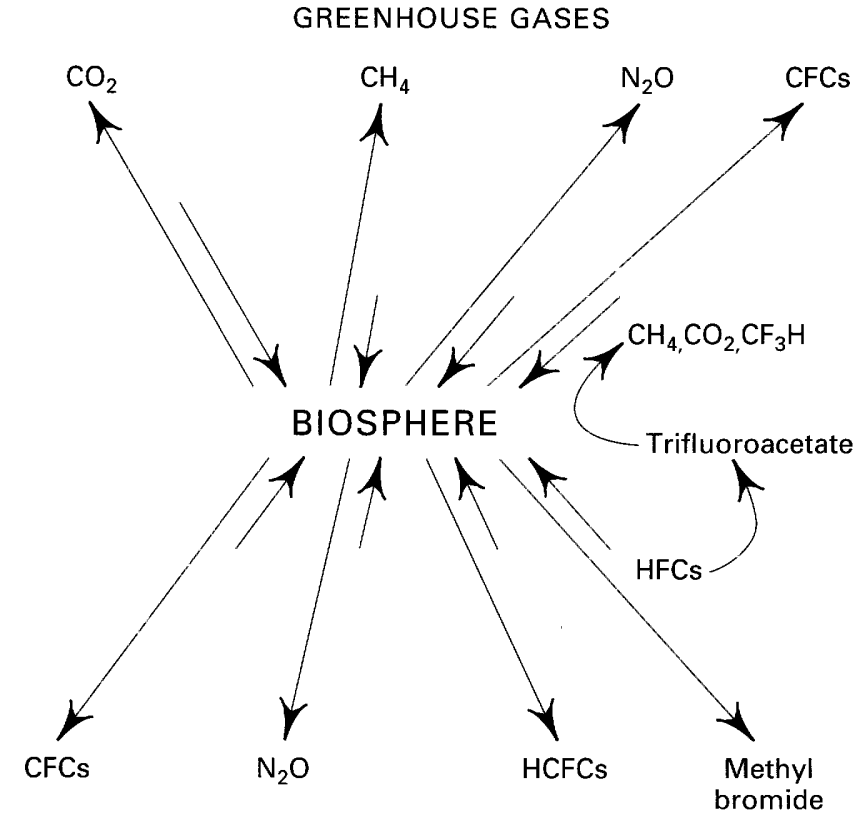

\section{OZONE-DESTROYING GASES}

Figure 1 (Oremland and Kvenvolden). Some key atmospheric trace gases which affect global warming and ozone chemistry. Arrows indicate qualitatively the relative proportion of release from the biosphere to uptake from the atmosphere by the biota.
Table 1 (Oremland and Kvenvolden). Annual methane release rates for identified sources (modified from Cicerone and Oremland, 1988).

\begin{tabular}{lrc}
\hline \multicolumn{1}{c}{ Identity } & Annual release $\left(10^{12} \mathrm{~g} \mathrm{CH}_{4}\right)$ \\
\hline & 80 & $(15$ percent $)$ \\
Animal intestinal tracts & 115 & $(21$ percent $)$ \\
Wetlands & 110 & $(20$ percent $)$ \\
Rice paddies & 55 & $(10$ percent $)$ \\
Biomass burning & 40 & (7 percent) \\
Termites & 40 & $(7$ percent $)$ \\
Landfills & 10 & $(2$ percent) \\
Oceans & 5 & $(1$ percent $)$ \\
Freshwaters & 5 & $(1$ percent $)$ \\
Methane hydrate destabilization & 35 & $(6$ percent $)$ \\
Coal mining & 45 & $(8$ percent) \\
Gas drilling, venting, transmission & 540 & \\
$\quad$ TOTAL & & \\
\hline
\end{tabular}

HFC 134a (tetrafluoroethane), ultimately give rise in the atmosphere to trifluoroacetate, a compound resistant to destruction, although evidence for biodegradation was recently reported (Visscher and others, 1994). Nitrous oride $\left(\mathrm{N}_{2} \mathrm{O}\right)$ is another important gas to consider. It is formed f ${ }^{\circ} \mathrm{m}$ the combustion of fossil fuels, as well as from agricultural and natural sources, and functions both as a greenhouse gas and as a stratospheric ozone-depleting agent. We cannot here delve into details of the global cycles and potential environmental hazards posed by all of these gases. The point is, however, that a number of trace gases contribute to global warming and (or) influence stratospheric ozone chemistry, and that a number of these substances interact chemically with each other. Hence, mention of these non-methane tace gases is also relevant to the overall question of the environmental effects of energy usage upon the environment.

\section{REFERENCES}

Blake, D.R., and Rowland, F.S., 1988, Continuing worldwid? increase in tropospheric methane, 1978 to 1987 : Science, v. 239, p. $66-68$.

Cicerone, R.J., and Oremland, R.S., 1988, Biogeochemical aspects of atmospheric methane: Global Biogeochemical Cycles, v. 2, p. 299-327.

Dickenson, R.E., and Cicerone, R.J., 1986, Future global warming from atmospheric trace gases: Nature, v. 319, p. 109-115.

Dlugokencky, E.J., Masaire, K.A., Lang, P.M., Tans, P.P., St sele, L.P., and Nisbet, E.G., 1994, A dramatic increase in the growth rate of atmospheric methane in the northern hemisphere di ring 1992: Geophysical Research Letters, v. 21, p. 45-48.

Howell, D.G., Cole, Frances, Fanelli, Michael, and Wiese, Katryn, 1993, An introduction to The Future of Natural Gas, in Howell, D.G., ed., The future of energy gases: U.S. Geological Survey Professional Paper 1570, p. 1-12.

Jiang, Y., Yentekakis, I.V., and Vayenas, C.G., 1994, Methane to ethylene with 85 percent yield in a gas recycle electrocatalytic reactor-separator: Science, v. 264, p. 1563-1566. 
Lorenson, T.D., and Kvenvolden, K.A., 1993, A comparison of hydrocarbon gases from natural sources in the northwestern United States, in Howell, D.G., ed., The future of energy gases: U.S. Geological Survey Professional Paper 1570, p. 453-470.

Kvenvolden, K.A., 1988, Methane hydrates and global climate: Global Biogecchemical Cycles, v. 2, p. 221-229.

Kvenvolden, K.A., Collett, T.S., and Lorenson, T.D., 1993, Studies of permafrost and gas hydrates as possible sources of atmospheric methane at high latitudes, in Oremland, R.S., ed., Biogeochemistry of global change-Radiatively active trace gases: New York, Chapman \& Hall, p. 487-501.

Oremland, R.S., Miller, L.G., and Whiticar, M.J., 1987, Sources and flux of natural gases from Mono Lake, California: Geochimica et Cosmochimica Acta, v. 51, p. 2915-2929.

Steele, L.P., Dlugokencky, E.J., Land, P.M., Tans, P.P., Martin, R.C., and Masarie, 1992, Slowing down of the global accumulation of atmospheric methane during the 1980s: Nature, v. 358 , p. 313-316.

Steudler, P.A., Bowden, R.D., Melillo, J.M., and Aber, J.D., 1989, Influence of nitrogen fertilization on methane uptake in temperate forest soils: Nature, v. 341, p. 314-316.

Visscher, P.T., Culbertson, C.W., and Oremland, R.S., 1994, Degradation of trifluoroacetate in anoxic and oxic sediments: Nature, v. 369, p. 729-731.

\section{The Paradigm of Rapid Climate Change- A Current Controversy}

\section{Joan Fitzpatrick, U.S. Geological Survey, Denver, CO 80225}

A new paradigm is currently emerging in the field of paleoclimatology as a result of recent analyses on two ice cores $^{1}$ recovered from the center of the Greenland ice sheet. Evidence for changes in climate from full glacial to full interglacial conditions over much shorter periods of time than previously observed (3-20 years) has been reported in the isotopic, electroconductivity, and net annual accumulation records from these cores (GRIP Members, 1993; Taylor and others, 1993; Alley and others, 1993). These rapid changes were detectable for the first time due to the extraordinary highly resolved record supplied by these cores. These apparent rapid changes in climate have been reported in ice from the last glacial (Weichselian) and the penultimate interglacial (Eemian) and appear to have occurred frequently during these times. Indeed, the proxy climate records for these periods have an almost binary appearance and have been characterized as "flickering between preferred states***" (Taylor and others, 1993) in testimony to a fundamental

\footnotetext{
${ }^{1}$ The Greenland Ice Sheet Program Two (GISP2) and Greenland IceCore Project (GRIP) cores were recovered over the period 1989-1993. The drill sites are located near the summit of the Greenland ice sheet, approximately $30 \mathrm{~km}$ apart. The projects are sponsored respectively by the U.S. National Science Foundation and the European Science Foundation.
}

instability in the climate during these times. Another remarkable characteristic of the climate signal in these cores is that the instability so apparent in the older part of the record is completely absent in ice from the rurrent interglacial (Holocene) in which we live (fig. 1). The implications of this heretofore unrecognized behavior are profound.

As with the emergence of any new pradigm, uncertainties and opportunities for misinterpretation and over-interpretation abound. Questions immediatcly arise about the relation between the quantity analyzed in the core and its relation to the actual climate. Are alterna ${ }^{+*}$ interpretations of the data possible? How regional (as opposed to global) might this signal be in scope? How reliable are the actual data and what other processes besides a change in climate might give rise to the observed signal? Are there data from other sources which refute or corroborate the interpretation of these data? Is this behavior compatible with our urderstanding of the mechanisms which drive climate change or will new mechanisms have to be proposed? These questions are now all being asked as a period of intense scientific scrutiny begins. This current period of intense scientific activity has been compared with the period of time "just before plate tectonics theory crystallized" (Bond, 1994) and thus can rightly be considered as a major paradigm shift in the making. Underlying all of these questions is a fundamental, social question: How can society respond to the possibility of a climate system which can reorganize and change drastically in so short a period of time? The coeval development of stable climate and the rise of civilization after the clos: of the last glacial period 11 to 12 thousand years ago has teen remarked upon by more than one researcher. Indeed, there are those who believe that climate change acted as a forcing function on the evolution of man during the last glacial enoch.

An important issue given an increas 9 sense of urgency by the new paradigm is the role anthropogenic inputs may play in forcing the climate system and the extent to which these inputs may be affecting feedback-control mechanisms which provide climate stability. For example, although the link between greenhouse gas concentrations and mean temperatures has been clearly demonstrated from many different types of paleoclimate indicators, unequivocal information about the lead-lag relationship between these two climaterelated parameters has not yet been acquired. In light of the new paradigm, the burning question changes from, "Will an increased concentration of greenhouse gases in the atmosphere cause the Earth's atmosphere tc warm?" to, "Will such an increase cause the climate to become unstable?" Intervention and mitigation may be possible in the first, simple scenario. It may not be possible in the second, much more complex scenario.

The issue of causal mechanisms is of equal importance in any consideration of a rapid climate change paradigm. The only component of the global climate system which can respond on a decadal to subdecadal tim scale is the atmosphere. However, if the atmosphere is responding to 


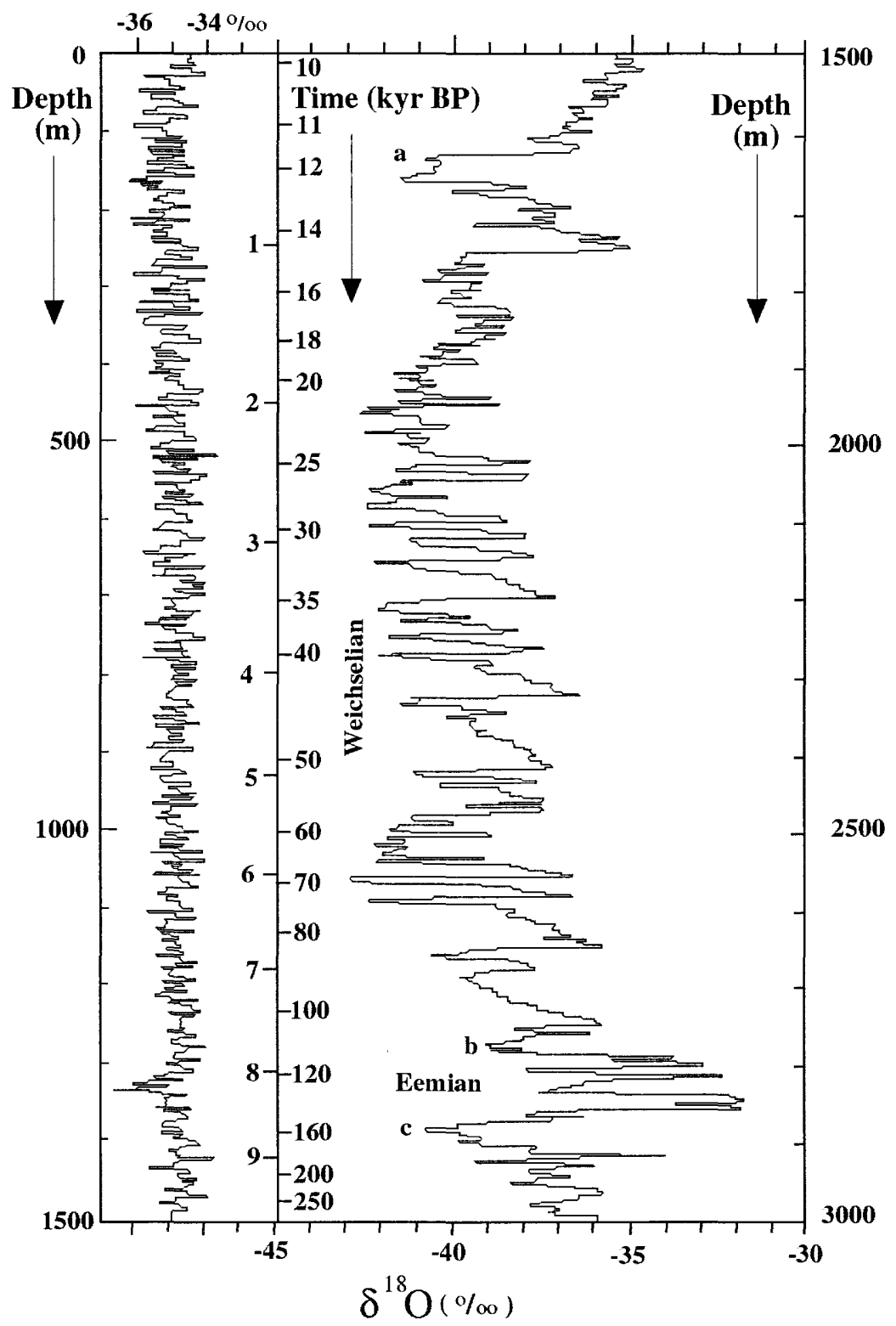

Figure 1 (Fitzpatrick). Stable isotope $\left(\delta^{18} \mathrm{O}\right)$ record from the GRIP core from Dansgaard and others, 1993. Values of $\delta^{18} \mathrm{O}$ are a proxy for atmospheric temperature at which the snow has formed. The data on the left are from the current climatically quiet Holocene. The data on the right are from previous glacial (Weichselian, between $a$ and $b$ ) and interglacial (Eemian, between $b$ and c) periods and show more than twice the variability of the Holocene data. Some of the transitions from full glacial to full interglacial temperatures are accomplished in less than 10 years. Other evidence indicates that the transition out of the end of the last glacial into the Holocene (at a) happened in 3 to 5 years. The two datasets are plotted on the same horizontal scale and join at 1,500 meters.

phenomena originating elsewhere in the climate system which are at or near a critical threshold value, major reorganizations in the atmosphere may occur as a result of a seemingly insignificant change in that component of the system. The key to understanding lies in identifying the physical parameters in the global climate system which operate with critical thresholds and in being able to model their behavior and their effect on the rest of the system. Current General Circulation Models (GCM's) neither predict nor model the type of major climatic changes hinted at in the Greenland ice cores on a decadal to subdecadal scale. We are quite clearly still missing some key pieces to the puzzle. In light of this 
realization, finding answers to the question of anthropogenic tinkering becomes even more urgent.

\section{REFERENCES}

Alley, R.B., Meese, D.A., Shuman, R.A., Gow, A.J., Taylor, K.C., Grootes, P.M., White, J.W.C., Ram, M., Waddington, E.D., Mayewski, P.A., and Zielinski, G.A., 1993, Abrupt increase in Greenland snow accumulation at the end of the Younger Dryas event: Nature, v. 362, p. 527-529.

Bond, G., 1994, Massive iceberg armadas offer new piece in climate puzzle: Lamont-Doherty Earth Observatory News, p. 3.

Dansgaard, W., Johnson, S.J., Clausen, H.B., Dahl-Jensen, D., Gundestrup, N.S., Hammer, C.U., Hvidberg, C.S., Steffensen, J.P., Sveinbjørnsdottir, A.D., Jouzel, J., and Bond, G., 1993, Evidence for general instability of past climate from a 250-kyr icecore record: Nature, v. 364, no. 6434, p. 218-220.

Greenland Ice-core Project (GRIP) Members, 1993, Climate instability during the last interglacial period recorded in the GRIP ice core: Nature, v. 364, p. $203-207$.

Taylor, K.C., Lamorey, G.W., Doyle, G.A., Alley, R.B., Grootes, P.M., Mayewski, P.A., White, J.W.C., and Barlow, L.K., The "flickering switch" of late Pleistocene climate change: Nature, v. 361 , p. $432-436$.

\section{Natural Radionuclides in Earth, Air, and Water, and the Effect on Human Health}

\author{
Linda C.S. Gundersen, U.S. Geological Survey, \\ Denver, CO 80225, and Zoltan Szabo, \\ U.S. Geological Survey, 810 Bear Tavern Road, \\ W. Trenton, NJ 08628
}

\section{Introduction}

Naturally radioactive elements, also known as radionuclides, are found throughout the ecosystem, in rocks, soils, water, air, and biota. In turn, radionuclides are breathed in or ingested by humans and animals. In sufficient quantities radionuclides can pose a health threat and are implicated in numerous types of cancers and birth defects. Radionuclides are inherently unstable, and the most common radionuclides in nature are formed by the radioactive decay of uranium238 and thorium-232. Decay of radionuclides produces radioactivity in the form of gamma rays, alpha particles, and beta particles. Figure 1 is a gamma-ray exposure map of the United States produced from an aerial survey of the radioactivity from uranium, thorium, and to a lesser extent, potassium. This map shows the distribution of these elements in surface soils and rocks. Also displayed are the radionuclide decay series which are initiated by the decay of uranium-238 and thorium-232. Radionuclides have a half-life, defined as the period of time it takes for one-half of the initial quantity of a radioactive element to decay. Each radionuclide has a unique half-life, but shares chemical prenerties with other isotopes of the same element. The most common radioactive progeny from uranium and thorium that ar` of environmental concern are the isotopes of radium and redon. The distribution of these parent radionuclides, to some extent, controls the distribution of the radioactive progeny and allows for prediction of the distribution of radionuclines in the environment using geologic and chemical models.

In soils and rocks, uranium and thorium occur as oxides or form minerals such as uraninite and mcnazite. Rock types which typically have uranium concentrat:ons greater than 2 parts per million (ppm) include carbonaceous black shales, glauconite-bearing sandstones, loess, ph tary rocks, granitic metamorphic and igneous rocks, and all types of economic uranium deposits. As the rocks break down to form soil, radionuclides are dispersed out of minerals and bond by electrostatic interactions with metal hydroxides, organic compounds, and surfaces of clay particles in the soil. Uranium and radium move relatively easily in the soil environment whereas thorium is generally immobile. Radium in soil and water is also taken up into several kinds of plants.

\section{Radon in Indoor Air}

Radon gas in indoor air is thought to be the second leading cause of lung cancer in the United States. Radon-222 has a half-life of 3.82 days and is produced by decay of uranium238. Radon-220 has a half life of 56 seconds, is produced from the decay of thorium-232, and is generally less abundant than radon-222. Radon emits alpha particles and produces several short-lived isotopes of polonium. It is the polonium solids that are the principal health hazard associated with radon. As radon is inhaled and d cays, polonium is deposited in the lung. Polonium also adhores to particles in the air and can be inhaled directly. Alpha radiation produced by polonium damages the cells lining the lung.

Radon forms from radium in the rocks and soils and moves into pore spaces and fractures where it is available to migrate freely. However, the distance radon can travel is limited by its short half-life of a few days. Radon enters a building when a pressure difference exists between the soil (high pressure) and the building (low pressure) by moving through cracks, wall and pipe joins, sump holes, drains, and porous building material. Recent studies of the distribution of radon potential in the United States were conducted by the U.S. Geological Survey in cooperation with the Environmental Fotection Agency (Gundersen and others, 1992). These st idies evaluate the sources of radon in rocks and soils using geologic models, soil permeability, uranium concertration data, and indoor radon data. Rocks and soils that are the source of 
the highest radon in the United States include all the rock types mentioned previously with greater than $2 \mathrm{ppm}$ uranium, soils derived from carbonate rocks, and also many kinds of rocks, soils, and surface deposits with high permeability such as glacial deposits and river gravels. Parts of the country with the highest radon potential include the glaciated Midwest, the Appalachian and Rocky Mountains, and the areas of the Great Plains and Appalachian Plateau that are underlain by uraniferous black shales.

\section{Uranium and Radium in Mining and Radium from Fossil Fuels}

The redistribution of natural radionuclides by the mining and nuclear industries leads to significant contact of these materials with humans and local environments. Mine water ordinarily contains measurable concentrations of uranium and other soluble radionuclides, such as radium. Mine water is typically pumped into retention ponds to allow settling of suspended solids and sorption of dissolved radionuclides to sediment or organic matter. Drainage water from mines and mine spoils also carries radionuclides, particularly where the waters are acidic. These types of acid waters are common in mines containing rocks high in sulfide minerals such as pyrite. Outflow from retention ponds, mines, and mine spoils enters the natural drainages of surface and ground water, contaminating these waters with measurable concentrations of radionuclides that migrate through the ecosystem (Van Metre and Gray, 1992). The concentrations that enter the ecosystem generally are lower than at the mine but in certain cases are high enough to constitute a health problem.

Approximately a third of the brine waters produced during the extraction of oil, gas, and coalbed methane contain high concentrations of radium. The precipitates formed on pipes and tanks (known as scale and sludge) during recovery of these fossil fuels can also have very high radium concentrations. Although the brines and their precipitates have long been recognized as a waste-disposal problem, the presence of radium has only recently been documented and studied.

\section{Uranium, Radium, and Radon in Ground and Surface Waters}

Because radionuclides are ubiquitous in rocks and soil, they are also present in water. In certain parts of the United States, ground and surface waters contain concentrations of radionuclides detrimental to human health even where uranium or thorium enrichment in rocks is not present (Zapecza and Szabo, 1988). The most common radionuclides in ground water are radon-222, radium-226, radium-228, uranium-234, and uranium-238. Because of its high solubility but short half-life, concentrations of radon are highest in ground water directly in contact with uranium-rich rocks and sediments, such as the granitic rocks of the New England Appalachians and the Western United States. Radon is quickly released to the atmosphere from turbulent surface waters but can be detected in slow-moving streams fed mostly by ground water. Uranium is soluble only in oxidizing waters, especially when they are alkaline. Unlike radon, the half-life of uranium is extremely long, and it can travel for long distances along ground- and surface-water flowpaths. Concentrations of uranium are highest in oxidizing, usually shallow, ground water that has had contact along its flowpath with uranium-rich rocks and sediments, such as the granitic rocks of the Appalachians and granitic rocks and alkaline sediments of the Western United States. Alkaline surface waters in the Western United States can also contain high concentrations of uranium. Radium is generally less soluble than uranium and radon, and in many places is not present in water, even if it has had contact with uranium- or thorium-rich rocks. In some areas radium is less soluble because chemical mechanisms (primarily electrostatic interactions with particle surfaces) are active. Where the chemical mechanisms that limit radium dissolution are not active, then relatively elevated concentrations of radium may be present in water, even from relatively uranium- and thoriumpoor aquifer rocks. This chemical behavior appears to explain the presence of radium in water in, for example, the sandstone aquifers of the mid-continental United States, the sand aquifers of the Atlantic Coastal Plain, and the sandstone/shale aquifers of the Central Appalachians, where high dissolved solids, acidic water, and oxygen-poor water, respectively, limit electrostatic interactions with particle surfaces.

\section{REFERENCES}

Gundersen, L.C.S., Schumann, R.R., Otton, J.K., Owen, D.E., Dubiel, R.F., and Dickinson, K.A., 1992, Geologic radon potential of the United States, in Gates, A.E., and Gundersen, L.C.S., eds., Geologic controls on radon: Geological Society of America Special Paper 271, p. 1-16.

Phillips, J.D., Duval, J.S., and Ambroziak, R.A., 1993, National geophysical data grids; Gamma-ray, gravity, magnetic, and topographic data for the conterminous United States: U.S. Geological Survey Digital Data Series DDS-9, one ISO-9660 format CD-ROM disk.

Van Metre, P.C., and Gray, J.R., 1992, Effects of uranium mining discharges on water quality in the Puerco River Basin, Arizona and New Mexico: Hydrological Sciences Journal, v. 37, no. 5, p. $463-480$.

Zapecza, O.S., and Szabo, Zoltan, 1988, Natural radioactivity in ground water-A review, in National water summary 1986, Ground water; Hydrologic conditions and events: U.S. Geological Survey Water-Supply Paper 2325, p. 50-57. 


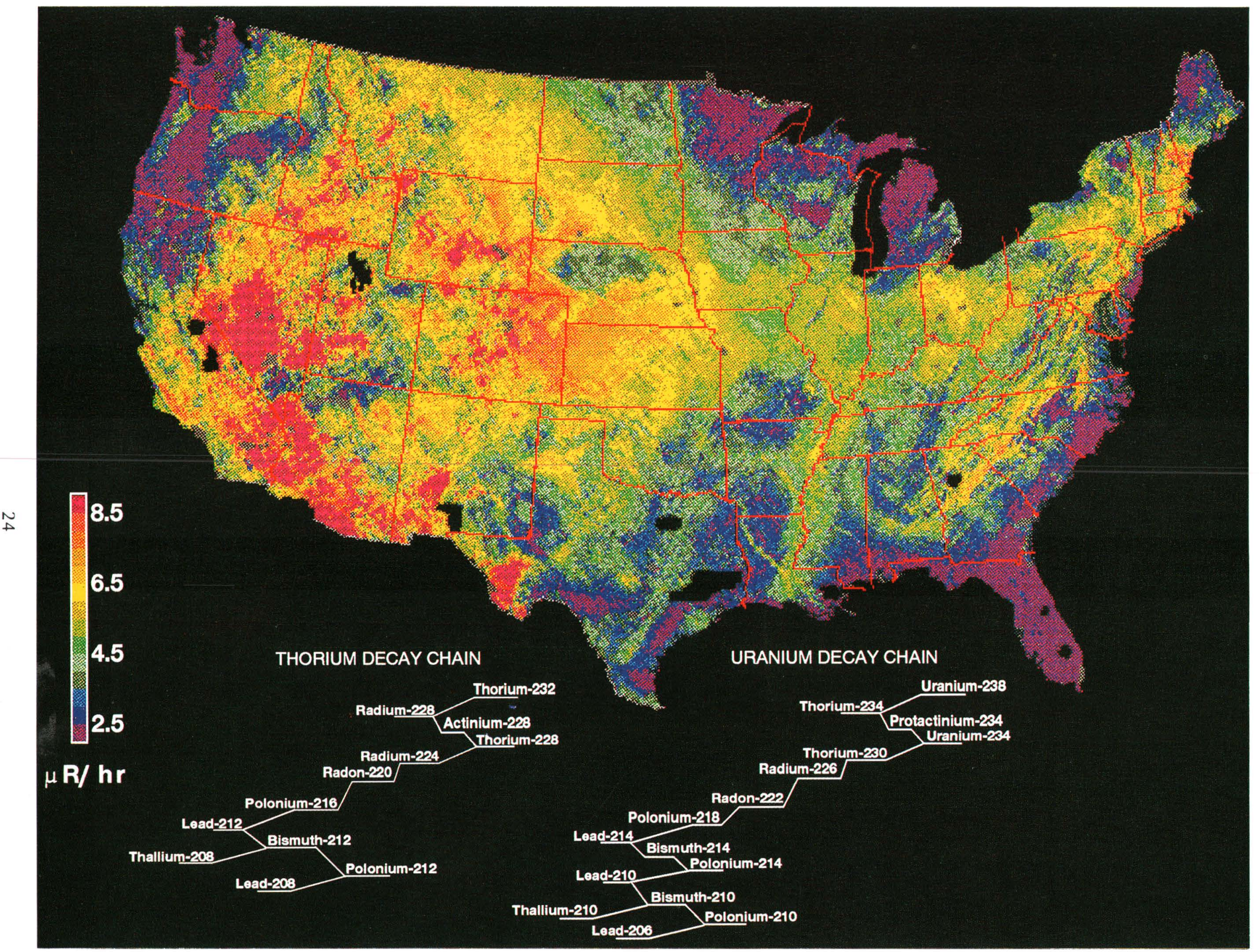

Figure 1 (Gundersen and Szabo). Terrestrial gamma-ray exposure at 1 meter above the ground (Phillips and others, 1993). Units are in microroentgens per hour $(\mu \mathrm{R} / \mathrm{hr}$, a measure of radiation). Also shown are the uranium- 238 and thorium- 232 decay series radionuclides. The number after each radionuclide is its atomic mass number, which is equal to the number of 


\section{Water Quality Degradation Associated With Natural Energy Sources}

\author{
Yousif K. Kharaka and Richard B. Wanty, \\ U.S. Geological Survey, Menlo Park, CA 94025, \\ and Denver, CO 80225
}

For 150 years, fossil fuels-coal, oil, and natural gas-supplemented more recently by fissionable nuclear fuel, have been the main sources of energy supply for the world's industrial societies. Extraction and utilization of increasing amounts of energy, however, have caused major local, regional, and global-scale environmental damage, including air and surface-water pollution, acid rain, global climate change, catastrophic nuclear reactor failures (as at Chernobyl in 1986), and marine oil spills. Water quality degradation attributable to energy utilization is documented in large increases in contaminant concentrations in rivers and lakes of developed countries, over time. For example, average sulfate concentrations, the best index of regional contamination from energy sources, have increased in the Mississippi River at New Orleans, La., from about 25 to $55 \mathrm{mg} / \mathrm{L}$ (milligrams per liter) between 1905 and 1990.

For oil and natural gas, which supplied 66 percent of the primary energy consumption in 1991, contamination hazards stem mainly from the large amounts of saline formation water produced during drilling and petroleum production. We estimate that in 1993, about 25 billion and 0.3 billion bbl (barrels) of formation water were produced with 2.5 billion bbl of domestic crude oil and 18 TCFG (trillion cubic feet of gas), respectively. This is three times the volume of water produced in 1970, and the increase resulted, even though petroleum production has declined, because the volume of produced water relative to petroleum increases with time, reaching 98 percent of total fluids during the later stages of field production.

The volume of wastes generated from about 26,000 wells drilled for oil and gas in 1993, including drilling mud, circulated cement, rock cuttings, completion fluids and produced water, is estimated at 0.13 billion to 1.0 billion bbl. Local water, soil, and air contamination from drilling operations is inevitable because wastes are generally stored in unlined pits. Since 1859 , approximately 3.5 million wells have been drilled for all oil and gas operations, but currently less than 1 million wells are producers. Improperly sealed abandoned wells can develop casing leaks that may act as conduits for fluid flow between aquifers; this flow has resulted in contamination of underground sources of drinking water.

Contamination potential of produced water depends on its chemical composition and method of disposal. Kharaka and Thordsen (1992) discussed the geochemistry of subsurface waters, showing that the salinity and chemical composition of produced water, which are controlle $t$ by the origin of water and water-mineral interactions, vary' greatly for different sedimentary basins (table 1, fig. 1). Wat $\%$ salinities range from about 3,000 to more than $350,000 \mathrm{~m}$ g/L dissolved solids and generally increase with depth, but this increase is reversed at greater depths in basins that are dominated by shales and siltstones and that lack evaporites (fig. 1). Chloride and sodium generally constitute $70-90$ percent of anions and cations, and calcium concentrations can reach $50,000 \mathrm{mg} / \mathrm{L}$. Concentrations of strontium, barium, iron, manganese, boron, and ammonia are generally highe- in subsurface water than in ocean water. The values for sulfate, bicarbonate, and magnesium are generally lower than in ocean water, and decrease with increasing subsurface temperatures, whereas those of lithium, potassium, rubidium, and cesium increase with increasing subsurface temperatures. Dissolved organic species, including mono- an 1 dicarboxylic acid anions, phenols, benzene, and toluene, can reach a total of about $10,000 \mathrm{mg} / \mathrm{L}$. Metals in oil-field waters, with the exception of iron and manganese, generally amount to less than $100 \mu \mathrm{g} / \mathrm{L}$; but metal-rich brines exist, as in the central Mississippi Salt Dome basin, where maasured values (in $\mathrm{mg} / \mathrm{L}$ ) are as much as 100 for lead, 250 for zinc, 500 for iron, and 200 for manganese. Uranium concentrations are low in these strongly reducing waters, but hazardous values of radium-226, radium-228, and radon- 222 have recently been found in wastes from several States.

About 65 percent of produced water is currently injected into producing oil zones for enhanced re-overy; deep well injection into aquifers with water salinities exceeding $10,000 \mathrm{mg} / \mathrm{L}$ accounts for about 30 percent. The remaining waste is discharged into surface waters, in-luding coastal waterways, bayous, estuaries, streams, lakes, and evaporation and percolation sumps. Produced water and drilling wastes from offshore operations, which amounted to about 1.0 billion bbl in 1990, are typically discharge $t$ to the ocean. Preliminary studies on the fate of contamirants in these wastes have indicated that because of rapid dilution, biodegradation, and evaporation of volatile comfonents, these wastes, which included $200,000 \mathrm{bbl}$ of oil, are considered to have no significant adverse effects on the marine ecosystem.

Prior to the regulations instituted in the 1970's : petroleum wastes were often discharged into rivers, streams, and unlined evaporation ponds, causing documented contamination, sometimes major, of soil and surface and grounc' waters in all the producing States. Since 1980, Congress has exempted "drilling fluids, produced water and other wastes associated with the exploration, development, or production of crude oil or natural gas or geothermal energy" from the stringent requirements of the hazardous waste manarement provision of the Resource Conservation and Recovery Act of 1976. Thus, Class II disposal wells, used for petroleum wastes, have less stringent completion, monitoring, and abandonment requirements and consequently greater 
Table 1 (Kharaka and Wanty). Chemical composition $(\mathrm{mg} / \mathrm{L})$ of produced formation waters from petroleum fields located in Central Valley, Calif.; North Slope, Alaska; Coastal Texas; and central Mississippi Salt Dome Basin.

[Depth is depth below ground level of mid-point of perforation. Temp. is measured subsurface temperature. Production zones are those used by oil companies. TDS is calculated total dissolved solids. $\mathrm{HCO}_{3}$ is field-titrated alkalinity and includes organic and inorganic species]

\begin{tabular}{|c|c|c|c|c|c|c|c|c|}
\hline \multirow{2}{*}{$\frac{\text { Area }}{\text { Field }}$} & \multicolumn{2}{|c|}{ Central Valley, CA } & \multicolumn{2}{|c|}{ North Slope, AK } & \multicolumn{2}{|c|}{ Coastal Texas } & \multicolumn{2}{|c|}{ Central Mississippi } \\
\hline & Grimes & $\begin{array}{l}\text { Wheeler } \\
\text { Ridge }\end{array}$ & Barrow & $\begin{array}{l}\text { Prudhoe } \\
\text { Bay }\end{array}$ & $\begin{array}{l}\text { Chocolate } \\
\text { Bayou }\end{array}$ & $\begin{array}{l}\text { East } \\
\text { Midway }\end{array}$ & $\begin{array}{l}\text { Reedy } \\
\text { Creek }\end{array}$ & $\begin{array}{l}\text { West } \\
\text { Nancy }\end{array}$ \\
\hline Sample \# & 81-NSV-15 & 75-WR-5 & 78-AK-52 & 78-AK-54 & 76-GG-7 & 77-GG-73 & 84-MS-11 & 84-MS-1 \\
\hline Well name & GOU4\#2 & $21-28$ & S. Barrow 5 & Arco 13 & Angle \#3 & Taylor E-2 & W.M. Goiger & W.L. West \\
\hline $\begin{array}{l}\text { Production } \\
\text { zone }\end{array}$ & Forbes & Tejon & $\begin{array}{l}\text { Barrow } \\
\text { Sandstone }\end{array}$ & $\begin{array}{l}\text { Sadlerochit } \\
\text { Group }\end{array}$ & $\begin{array}{l}\text { Upper } \\
\text { Weiting }\end{array}$ & $\begin{array}{l}\text { Lower } \\
\text { Frio }\end{array}$ & Rodessa & Smackover \\
\hline Depth (m) & 2,074 & 2,691 & 728 & 2,820 & 3,444 & 3,662 & 3,486 & 4,428 \\
\hline Temp. $\left({ }^{\circ} \mathrm{C}\right)$ & 65 & 117 & 16 & 94 & 118 & 128 & 102 & 118 \\
\hline TDS & 18,600 & 44,300 & 22,100 & 21,900 & 73,300 & 36,000 & 320,000 & 275,000 \\
\hline $\mathrm{Li}$ & 0.32 & 1.95 & 2.1 & 4.0 & 9.9 & 4.2 & 35 & 74 \\
\hline $\mathrm{Na}$ & 6,830 & 7,450 & 7,980 & 7,600 & 26,500 & 13,250 & 61,700 & 54,800 \\
\hline $\mathbf{K}$ & 35.5 & 135 & 3.0 & 86 & 400 & 72 & 990 & 6,500 \\
\hline $\mathbf{M g}$ & 72 & 27 & 67 & 20 & 220 & 48 & 3,050 & 3,350 \\
\hline $\mathrm{Ca}$ & 182 & 5,550 & 119 & 182 & 2,000 & 330 & 46,600 & 33,900 \\
\hline $\mathrm{Sr}$ & 14.3 & 187 & 16.1 & 20.2 & 365 & 23 & 1,920 & 1,670 \\
\hline $\mathrm{Ba}$ & 6.4 & 12 & 175 & 3.8 & 290 & 13 & 60 & 48 \\
\hline $\mathrm{Fe}$ & 0.58 & 2.8 & 5.5 & 63 & 10.2 & 1.6 & 465 & 0.47 \\
\hline $\mathrm{NH}_{3}$ & 34 & 32 & 19 & 17 & 29 & 13.5 & 34 & 119 \\
\hline F & ---- & 2.0 & 1.6 & 1.5 & 0.8 & 7.3 & 1.5 & 11.5 \\
\hline $\mathrm{Cl}$ & 11,000 & 21,450 & 11,800 & 10,600 & 42,700 & 21,000 & 198,000 & 170,000 \\
\hline $\mathrm{Br}$ & 44 & 80 & 62 & 54 & 52 & 45 & 2,020 & 2,080 \\
\hline I & 30 & 46 & 28 & 19 & 16 & 45 & 17 & 80 \\
\hline $\mathrm{HCO}_{3}$ & 359 & 2,210 & 1,710 & 2,930 & 455 & 1,180 & 206 & 197 \\
\hline $\mathrm{SO}_{4}$ & $<0.5$ & 50 & ----- & 69 & 2.7 & 42 & 64 & 161 \\
\hline $\mathrm{H}_{2} \mathrm{~S}$ & 0.07 & 0.11 & $<0.1$ & $<0.1$ & 1.2 & 0.04 & $<0.02$ & 57.4 \\
\hline $\mathrm{SiO}_{2}$ & 31 & 46 & 11 & 62 & 87 & 132 & 28 & 34 \\
\hline B & -.-- & 600 & 42 & 158 & 35 & 35 & 59 & 341 \\
\hline $\mathrm{pH}$ & 7.6 & 6.9 & 7.2 & 6.5 & 5.9 & 6.4 & $5.0 R$ & 5.48 \\
\hline
\end{tabular}

potential for contaminating underground sources of drinking water than those for hazardous wastes.

Coal is the most abundant fossil fuel, underlying 13 percent of the United States land area and with demonstrated reserve base that can meet all our energy requirements for more than 1,000 years. Coal was the dominant source of energy before 1950; currently it supplies about 25 percent of the total energy. Water quality in pristine coal beds varies greatly between coal provinces, depending on geologic, hydrologic, and climatic conditions. Water salinities vary from about 100 to more than $50,000 \mathrm{mg} / \mathrm{L}$; they generally range from 500 to $4,000 \mathrm{mg} / \mathrm{L}$ and are higher in coals from the Western United States. The waters are generally sodiumsulfate-bicarbonate type with minor chloride, calcium, and magnesium; dissolved organic constituents may be harmfully high. Coal seams and adjacent beds are drained prior to mining; the volume of water generated is variable, reaching approximately 10 million bbl per year in some mines in the Appalachian region. This water is used for reclamation, transportation of coal as slurry, and other mine operations; some water is released to surface water, causing stream pollution. The main environmental concerns of coal production, however, are the acid mine drainage and sediment erosion and deposition that have resulted in major regional degradation of streams, especially in the Appalactian region. Acid mine drainage, caused by percolation of oxygenated water into pyritic coal-mine spoils, is characterized by low $\mathrm{pH}$ values (less than 4) and high concentrations of sulfate (more than $1,000 \mathrm{mg} / \mathrm{L}$ ), iron (1-100 mg/L), manganese (more than $1 \mathrm{mg} / \mathrm{L}$ ), and other toxic metals including al 'minum, copper, lead, and zinc. Because of lower precipitation, lower sulfur content of coal, and the presence of carbcrnate minerals in soil, acid mine drainage is not a major issce in the Western United States, but saline water drainage is an issue of local concern.

Power from nuclear fission currently supplies close to 10 percent of the energy mix, and known uranium supplies can last for hundreds of years using stand ${ }^{-1} \mathrm{~d}$ reactors, and much longer in breeder reactors. Most of the United States uranium reserves are hosted in sandstones v'here water salinities are relatively low and dissolved uranium concentrations are very low. However, potentially harmf 1 concentrations of radium, radon, and hydrogen sulfide may' be present. Only minor volumes of water are recovered from surface and 


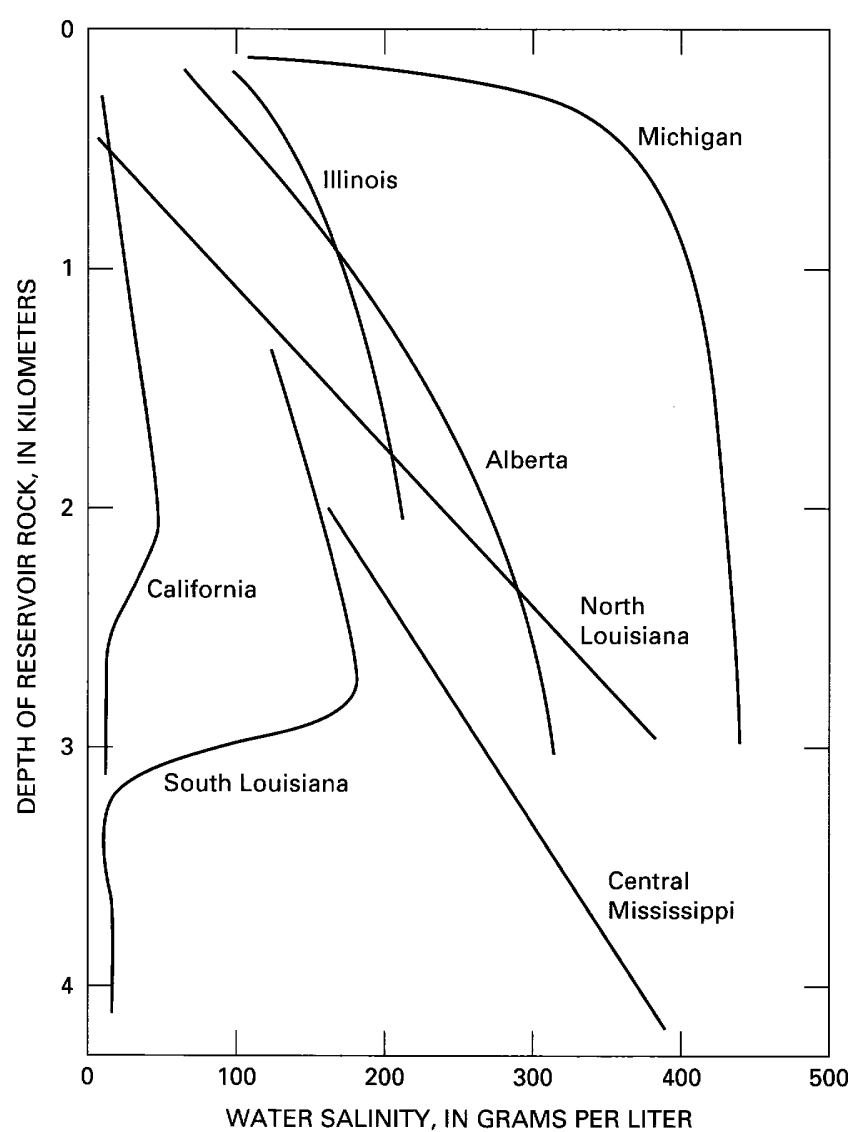

Figure 1 (Kharaka and Wanty). Salinity distribution of formation water with depth of reservoir rocks from several petroliferous basins in North America. Note the different trends and the reversal of salinity with depth in California and south Louisiana.

subsurface mining, but escape of dissolved uranium and radium from uranium mine tailings is potentially hazardous. The main environmental risks, which have precluded the commissioning of new nuclear power plants in this country since the mid 1970's, are the possibility of catastrophic reactor failures and uncertainties relating to safe management of radioactive wastes from reactors for thousands of years.

Geothermal energy, which is used primarily for generating electrical power, currently plays only a small role in the total energy mix. The resource base, however, is huge, especially if geopressured, hot dry rock and magmatic systems are included. Currently about 70 percent of geothermal power generation is from the vapor-dominated system at Geyser, California, but future increases will be from waterdominated systems. Air pollution from vented gases is the main environmental concem of geothermal energy production because all the produced water is reinjected into the producing rock formations to maintain system pressure. Airquality degradation is minor because only modest amounts of these produced gases are released-primarily carbon dioxide, methane, and ammonia - while hydrogen sulfide is generally recovered as sulfur prior to gas venting. Thermal water production generally results in the drying up $c^{f}$ natural thermal springs and mineral seeps associated with these systems resulting in an alteration of surface-water quality (usually improvement).

Exploration for and production of energy sources, disrupting the natural hydrologic cycle, have caused major contamination of surface and ground waters. This contamination will continue in the future unless more stringent stat "tes regulating the disposal of the wastes from these sorrces are enacted. In order to keep disposal costs affordable while minimizing environmental degradation, the new ręulations need to be based on a more comprehensive understanding of the nature of the contaminants and their interactions and fate in the geosphere.

\section{REFERENCE}

Kharaka, Y.K., and Thordsen, J.J., 1992, Stable isotope geochemistry and origin of waters in sedimentary basins, in C'auer, $\mathrm{N}$., and Chauduri, S., eds., Isotopic signatures and sedimentary records: New York, Springer-Verlag, p. 441-466.

\section{Our Future Energy Use-Environmental Concerns Beyond the Year 2000}

\author{
Peter J. McCabe, U.S. Geological Survey, \\ Denver, CO 80225
}

Historically, most predictions about the nature of future energy production, consumption, and use have proven to be incorrect, and there seems little reason to believe that we can more accurately predict the future now than in the past. However, as in the past, the demand for various forms of energy will almost certainly vary through time. Although many reserves have been depleted, this country still has a wealth of coal, natural gas, and oil that could su pply the Nation's energy needs for many decades to come - if we are willing to pay the fiscal and environmental costs of development. The alternatives are to import an increasing pe"centage of our energy, develop alternate energy sources, or to regulate energy consumption-all of which have their or'n costs. Critical factors will be the ability of various energy sources to meet the evolving energy demand, the develorment of new technologies, and political or societal requirements. The evolving energy mix will undoubtedly raise new environmental concerns: though some energy sources are arguably more environmentally friendly, we cannot harress any energy source without influencing the environment. Although the supply mix for future energy consumption is unclear, the range of possible environmental and societal concerns for the future is perhaps less uncertain. 
The impact of energy development on land management is likely to be an area of increasing environmental concern in the future. Energy exploration and production have a visual impact on a landscape, they influence ecosystems, and they conflict with many other types of land use such as recreation and farming. Because the average size of oil and gas discoveries has decreased over time, the number of wells that must be drilled to maintain production at current levels will increase substantially (National Petroleum Council, 1992). Many of the onshore sedimentary basins in which this exploration presumably will take place lie below Federal lands in the Western States, and increased energy development could have a profound effect on the landscape in this region. Coal production in the Western States has increased more than four-fold since 1975, and if this trend continues, increasing conflict is likely with the ecologic and recreational needs of National Parks, Monuments, and Wilderness Areas, even though the final visual impact of coal mining has decreased considerably over the last 20 years with improved reclamation efforts. If oil and gas imports continue to rise, there is likely to be additional pressure to allow exploration for fossil fuels in some of the Nation's most fragile ecosystems such as the Arctic National Wildlife Refuge (ANWR) in Alaska and on the continental shelf offshore California. Significant development of alternate energy sources such as wind and solar energy farms will also influence large tracts of land and have considerable visual impact and effect on ecosystems (fig. 1).

Substantial advancement has been made in some regards over the last 20 years in ameliorating the impact of energy use on the atmosphere. The amount of local air pollution over many cities has decreased because of regulations of emissions and the development of more fuel efficient vehicles. Passenger cars, for example, have an average fuel efficiency of about 22 miles per gallon today compared to about 13.5 miles per gallon in 1975. Controls on emissions from smoke stacks, particularly of coal-fired electrical generating plants, and switching to lower sulfur fuels can also cut down on the effects of acid rain. While undoubtedly pressure to reduce these forms of atmospheric pollution will continue, the larger question of emission of global greenhouse gases remains. The use of fossil fuels has obviously resulted in a significant increase in greenhouse gases in the atmosphere, but the effects of this increase are less clear (Jäger and Ferguson, 1991). If a marked change in global climate does indeed occur, there will be pressure to rapidly change the energy mix to reduce greenhouse gas emissions. Carbon dioxide - one of the major greenhouse gases-remains in the atmosphere for many decades; consequently, drastic reductions in emissions of the gas would be required to ameliorate any pronounced climate change. How quickly a change to alternate fuels could take place is a matter of question: History shows that several decades were required for coal, oil, natural gas, and nuclear energy to become significant components of the total energy mix. By contrast, the dramatic change in energy use after the 1974 oil embargo suggests that technological change can be rapid in certain political climates.

As water becomes an ever more valuable resource, the effects of energy production and utilization on water resources are likely to be of increasing concern. In the future, especially in the Western States, the need for water in many aspects of energy production will increasingly conflict with the growing need for water for other purposes. The costs of brine disposal will increase as more unconventional resources such as coalbed methane are developed. The decline in oil production from existing domestic fields and the closure of older coal mines will heighter the concern for long-term effects on aquifers after operators have abandoned these sites; in some cases the potential fo- environmental problems is increased after energy extraction ceases. For example, acid mine drainage can increase markedly after a coal mine is abandoned. During mining operations, water is pumped out of the mine; but when mines are abandoned, ground water rebounds and water is able to flush into solution products of pyrite oxidation that occurred during the active life of the mine (Younger, 1994).

Over the last 20 years concern about the global environment has been increasing; and this concern is likely to continue to grow, because the world population is forecast to increase by almost 50 percent over the next 30 years (World Resource Institute, 1992). If the additional energy use required to support such a population comes from fossil fuels, global emission of greenhouse gases vill rise substantially even if the per capita consumption of energy does not rise. Increased industrialization in the Third World would accelerate the trend. Alternatively, it can be argued that increased use of fossil fuels in many countries could have benefits for the environment, as one of the major sources of fuel for people in developing countries is fir?wood from forests and woodlands - a major factor in deforestation and desertification.

Geologists will play a vital role in determining the future availability of many energy sources and in reducing the environmental impact of almost all energy uses. By anticipating possible environmental concerrs, we may be in a better position to provide the scientific l asis for policymakers to avoid or mitigate the impact of future energy production on the environment.

\section{REFERENCES}

Jäger, J., and Ferguson, H.L., eds., 1991, Climate change-Science, impacts and policy: Proceedings of the Seccnd World Climate Conference, Cambridge University Press.

National Petroleum Council, 1992, The potential for natural gas in the United States, Volume II-Source and supply: Washington, D.C., National Petroleum Council, 330 p.

World Resource Institute, 1992, World resources 1992-93: New York, Oxford, 385 p.

Younger, P.L., 1994, Minewater pollution-T - revenge of old king coal: Geoscientist, v. 4, no. 5, p. 6-8. 

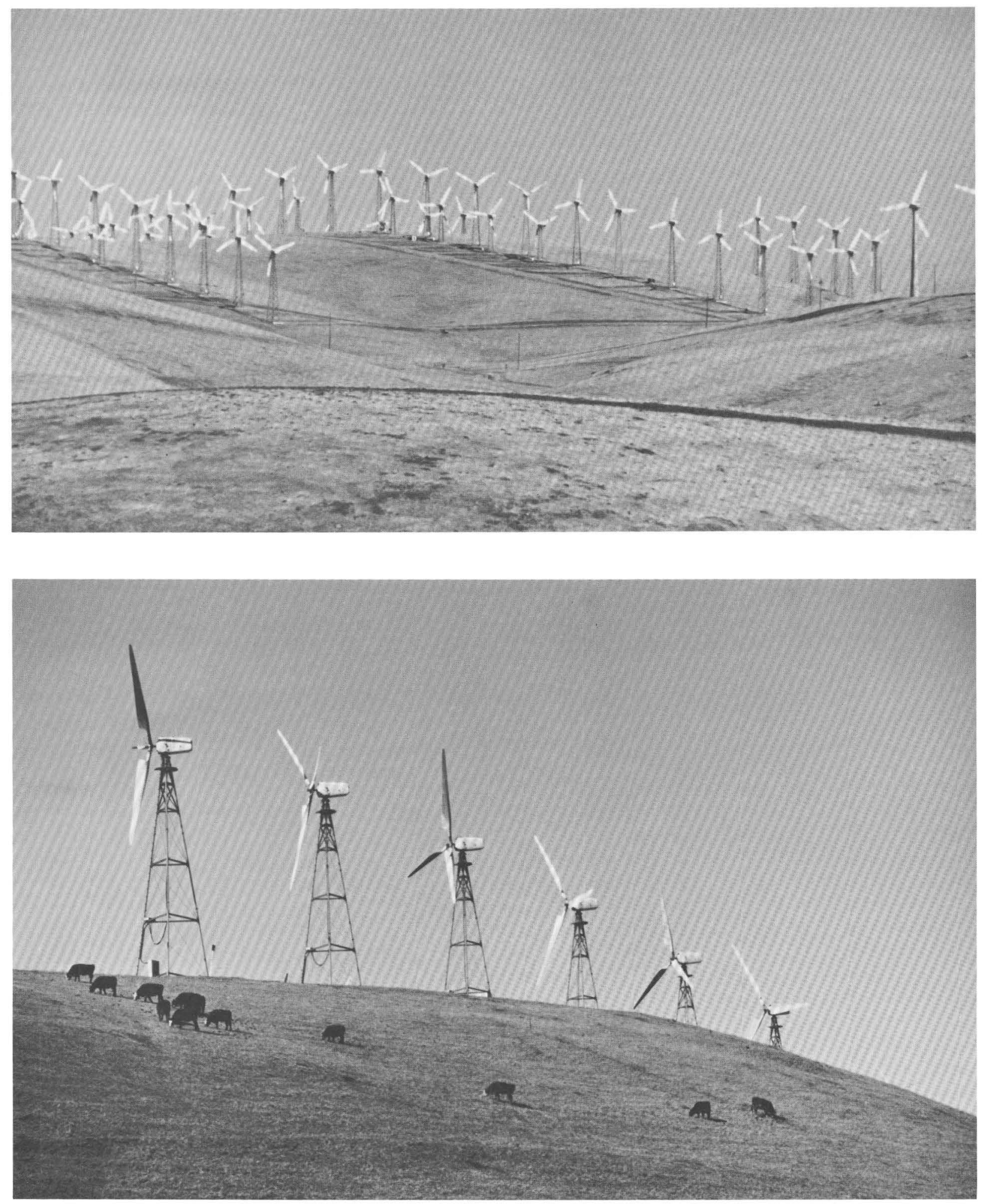

Figure 1 (McCabe). Although some energy sources are arguably more environmentally friendly than others, we cannot harness any energy source without influencing the environment. Wind turbines, for example, create noise, kill raptors, influence television reception, and have a visual impact on the landscape. A few of the 7,000 windmills of the Altamont Pass wind farm, California. 


\section{Effects of Energy Resource Development on Lakes-What Do We Need to Know?}

\author{
John T. Turk, U.S. Geological Survey, \\ Denver, CO 80225
}

The alpine and subalpine zones of the Rocky Mountains constitute one of the largest undisturbed ecosystems in the United States. The Wilderness and Clean Air Acts gave congressionally designated Wilderness Areas special protection from anthropogenic change. However, many Wilderness Areas of the Rocky Mountains are located near to and downwind from developed or economic deposits of fossil fuels, including coal, petroleum, natural gas, and oil shale. The need for abundant and reliable new energy sources likely will result in increased use of fossil fuels in the Rocky Mountains and other western areas. To use these energy minerals without damaging nearby Wilderness Areas and other Federal lands, we need to understand the present status of the Wilderness Areas and the potential risk associated with projected atmospheric emissions from energy resource development.

Very little is known about Rocky Mountain Wilderness Areas, which are characterized by lack of roads, steep terrain, and a seasonal snowpack that lasts about 9 months of the year. Most information regarding these areas consists of a few synoptic samplings and some monitoring and research at only a few small watersheds. Lack of information on Rocky Mountain Wilderness Areas hampers both their protection and the development of fossil fuels. In the absence of information necessary to predict the effects of new emissions sources, the Federal land manager is required by law to err in the direction of assuring that damage is not done. As a result, worst-case estimates of potential risks posed by proposed energy resource development commonly are used.

Most knowledge of the present status of Rocky Mountain Wilderness Areas and risk of damage to them is a result of study of acid rain and related problems and has been summarized by Turk and Spahr (1991). The National Atmospheric Deposition Program monitors the chemistry of rain and snow at about a dozen sites in the Rocky Mountain area. No sites are located in Wilderness Areas and few are located at high elevation. During 1993, the U.S. Geological Survey conducted a survey of snowpack chemistry throughout the Rocky Mountains. Generally, the smallest concentrations of fossil-fuel combustion products, such as sulfate, nitrate, and acidity in rain or snow and the snowpack, are in Montana. Concentrations progressively increase in Wyoming and Colorado. Some of the largest concentrations of sulfate, nitrate, and acidity were measured at several sites in an area in northern Colorado downwind (east) of the Yampa River valley. The Yampa River valley is an area of energy development, especially coal mining and electrical generation from coal.

The Western Lake Survey, conducted by the U.S. Environmental Protection Agency in 1985, and numerous smaller surveys indicate that the median acid neutralizing capacity (ANC), a measure of a lake's ability to neutralize acidity, is smallest in Wyoming and southern Montana and greatest in Colorado. Thus, the lakes having the smallest median ANC, and therefore the lakes most sensitive to acidification, tend not to be in the area having the greatest concentrations of sulfate, nitrate, and acidity in wetfall and in snowpack.

Effects of energy development on the wilderness hydrologic systems of median sensitivity are of secondary concern to the Clean Air and the Wilderness Acts; instead, most concern is for those systems considered the most sensitive. Data indicate that, even though median ANC differs greatly among regions in the Rocky Mountains, lakes having small ANC occur throughout the Rocky Mountains. Because of differences in bedrock geology, soil development, and hydrology, those lakes having smallest ANC tend to occur in specific mountain ranges, such as the Bitterroot Range (Montana), the Wind River Range (Wyoming), the Uinta Mountains (Utah), the Colorado Front Range, and the northern Park Range (Colorado).

One area where large concentration of sulfate, nitrate, and acidity in wetfall and snowpack overlaps with an area containing lakes of very small ANC is in northern Colorado, downwind of the Yampa River valley. Thus, at present levels of emissions from all sources, including energy development, this area containing the Mt. Zirkel Wilderness Area (MZWA) likely contains hydrologic systems that are the most affected in the Rocky Mountains. No lakes are acidic during the summer, when all sampling has been done. However, the initial stages of acidification would be greatest during early snowmelt, when the greatest concentrations of acidity are preferentially released. Such episodic acidification most likely would first affect small, ephemeral snowmelt pools favored by amphibians for breeding. Other studies indicate that the tiger salamander, which is endemic to the area, is sensitive at $\mathrm{pH}$ values commonly observed in the snowpack and wetfall in and near the MZWA. Thus, a combination of chemistry in wetfall, snowpack, and lakes might be predicted to result in biological effects in and near the MZWA, a Class 1 area (an area given the greatest level of protection) under the Clean Air Act. Farther downwind is Rocky Mountain National Park, another Class 1 area.

In addition to the concern caused by the potential effects on lakes and aquatic organisms in the MZWA, the likelihood that this area is the most affected in the Rocky Mountains offers some opportunities to protect Rocky Mountain Wilderness Areas. Little information exists to tell us what aspects of the hydrologic and biologic systems of Rocky Mountain watersheds are most responsive to 


\section{HYDROGEN ION LEVELS ALONG THE CONTINENTAL DIVIDE}

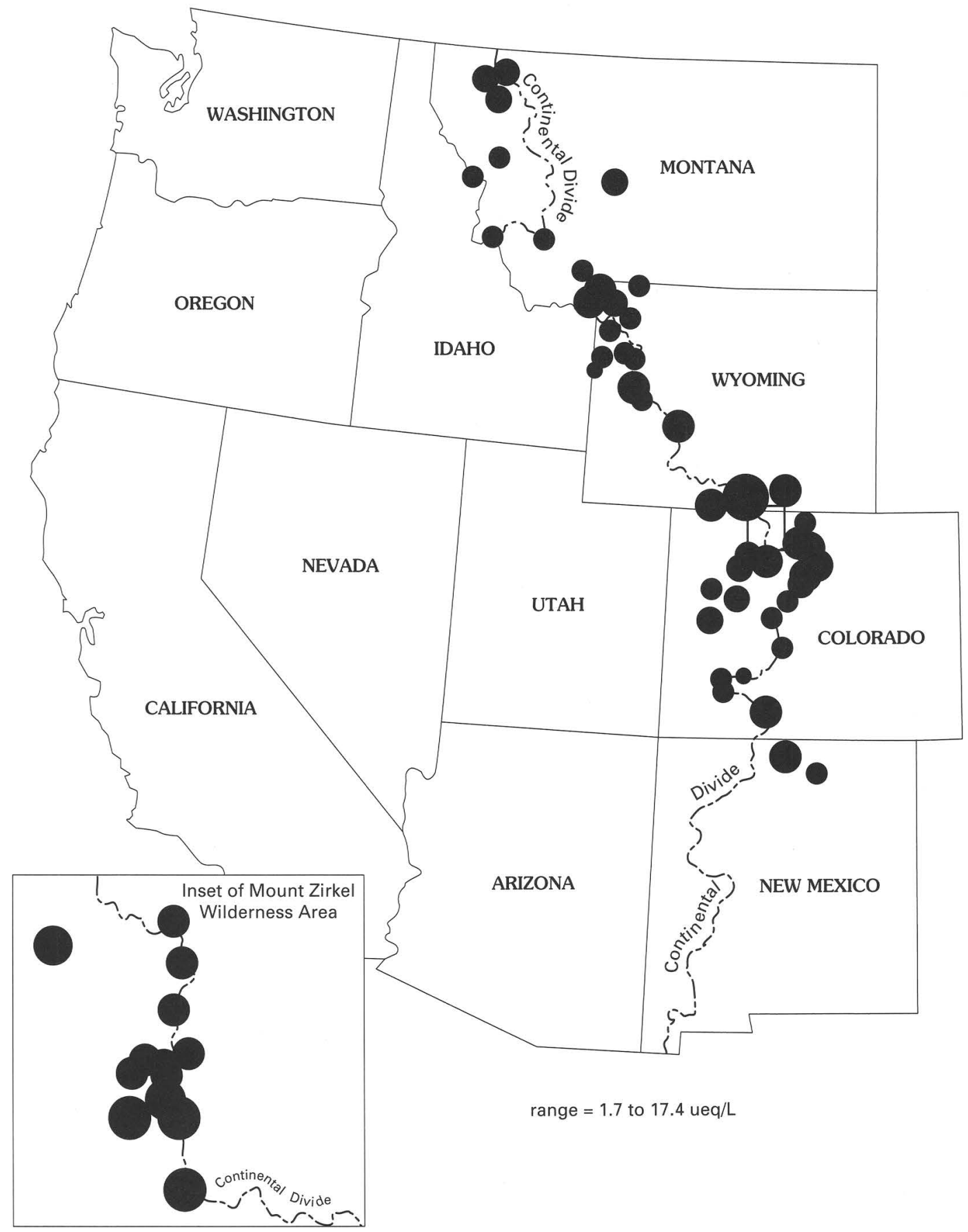

Figure 1 (Turk). Concentration of hydrogen ion (acidity) in the Rocky Mountain snowpack at end of 1992-3 snow season. A concentration of $10 \mu \mathrm{eq} / \mathrm{L}$ equals a $\mathrm{pH}$ of 5 , and greater concentrations equal $\mathrm{pH}<5$ (more acidic). The greatest concentrations occur in and near the Mt. Zirkel Wilderness Area, Colorado.

acidification. Further, although some damage might occur at present levels of emission, it is possible that hydrologic and other processes might protect these systems in ways not observed elsewhere. Thus, a well-planned evaluation of effects, or lack thereof, on lakes and aquatic organisms would be an invaluable calibration that would be useful in predicting effects of energy development and associated emissions everywhere in the Rocky Mountains. 

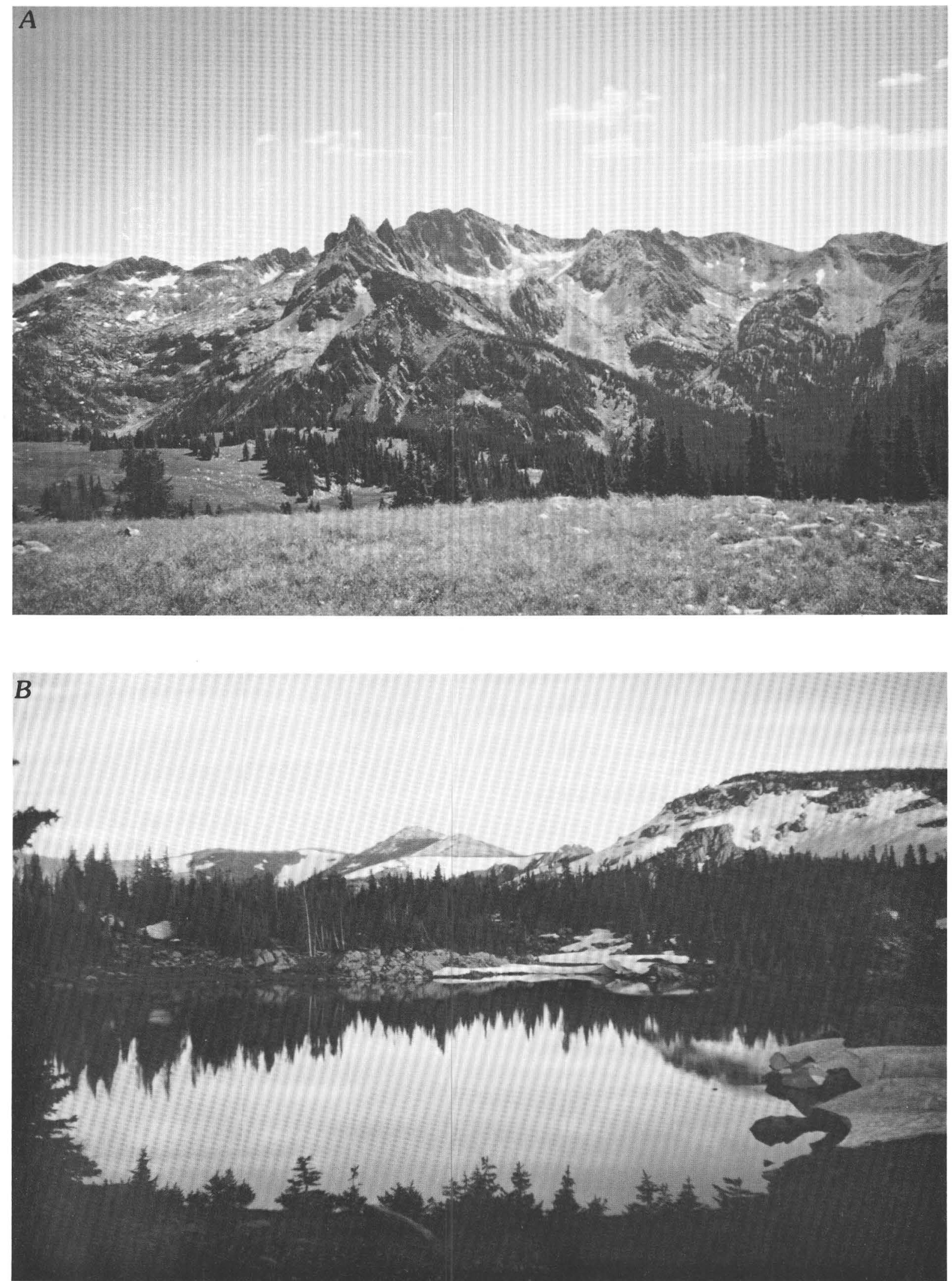
Figure 2 (Turk) (facing page). Clean air is critical to maintain spectacular vistas, such as that of Big Agnes Mtn. ( $A$, and background of $B$ ). Clean air is also critical to the health of wilderness streams and lakes such as Seven Lakes $(B)$. Both photos from the Mt. Zirkel Wilderness Area, Colorado, which has the most acidic snow in the Rocky Mountains.

\section{REFERENCE}

Turk, J.T., and Spahr, N.E., 1991, Rocky Mountains, in Charles, D.F., ed., Acidic deposition and aquatic ecosystems-Regional case studies: New York, Springer-Verlag, p. 471-501.

\section{How Can Geoscientists Help Policy Makers Assess the Impact of Energy Extraction on Marine Ecosystems?}

\author{
H.A. Karl, R.L. Bernknopf, U.S. Geological \\ Survey, Menlo Park, CA 94025, D.R. Soller, \\ U.S. Geological Survey, Reston, VA 22092, and \\ P.S. Chavez, Jr., U.S. Geological Survey, \\ Flagstaff, AZ 86001
}

Concerns about possible environmental damage to the world's oceans were expressed more than 30 years ago. With recent improvements in mapping and monitoring technology, the effects of anthropogenic stress on marine ecosystems are beginning to be understood by scientists and other consumers of marine information products. The oceans are increasingly used as a source of inorganic resources, food, recreation, and as a repository for waste products. To assure that human activities do not interfere with or preclude other activities, policy makers must have the best scientific information possible to guide them in making wise choices concerning the use of the marine environment for the long-term good. In accord with the focus of the $1995 \mathrm{McKelvey}$ Forum on the application of geoscience to decision-making, we neither recount other studies nor do a literature review on the impact of oil production and other forms of energy extraction and related pollution on marine ecosystems; rather, we present, explore, and suggest new techniques to use and value marine geoscience information that are appropriate for quantitative risk assessment to help formulate public policy in the 21 st century.

The impact of energy extraction on marine ecosystems is not limited to the site of production, but has potentially far reaching effects in regard to the disposal of byproducts and waste products generated during production, processing, and consumption of energy products, as well as mishaps that could occur during their transportation. Areas available for energy extraction and waste disposal, and transportation corridors are being increasingly limited and restricted in the marine environment, principally owing to the fear of damage to fragile ecosystems. For example, about $17,000 \mathrm{~km}^{2}$ (an area larger than Connecticut and Rhode Island combined) of the contiguous central California coastal ocean is protected by three national marine sanctuaries - Cordell Bank, Gulf of the Farallones, and Monterey Bay-that stretch over $\approx 00 \mathrm{~km}$ from Bodega Bay north of San Francisco to Cambris south of Monterey.

USGS has been conducting studies offshore the San Francisco Bay area where the environmental and eco'rgical concerns of the Gulf of the Farallones National Marine Sanctuary must be reconciled with the human, economic, and industrial demands of a major urban population center. It is here that we are developing techniques to quantify the net benefits of various types of marine information to sxiety. We want to establish a societal value for seafloor maps similar to that done for geologic maps for various land-use issues (see Bernknopf and others, 1993). Evaluation cf society's willingness to pay for seafloor maps is a way to demonstrate the relevance of the earth science information. By integrating scientific information with other facto-s that influence policy decisions, we can identify the applicability and utility of the research results.

Our Gulf of the Farallones National Marine Sarctuary case study is an application to evaluate environmental management and environmental regulation issues to help determine the highest and best use of the seafloor. Currertly we are aware of approximately 50,000 barrels and other containers of radioactive waste that were disposed of on the seafloor west of the Farallon Islands between 1946 and 197). The barrels were to be dumped at three specific sites, but for various reasons dumping was not confined to those sites and the barrels litter a $1,200 \mathrm{~km}^{2}$ area (called the Farallon Island Radioactive Waste Dump) of seafloor so that the exact location of most of the barrels is unknown. We have su'veyed about 15 percent of the dumpsite area with a sidescan sonar system at two different swath widths $(1 \mathrm{~km}$ and $5 \mathrm{~km})$ and have developed techniques for detecting the steel barrels (Karl and others, 1994; Chavez and Karl, in press). Tr : Gulf of the Farallones and adjacent waters are a major f'shery. The impact that the barrels have on the marine ecosy:tem is unknown. Anecdotal fear of radiation contamination $\mathrm{l}$ as had an adverse impact on the commercial fisheries market in the past. The first step to quantifying the value of the sonar maps to society is to use these data to develop a probability distribution of the barrels over the FIRWD. The model will be used to compare the statistical accuracy of sonar data of different swath width (different resolution). This infornation can be used by agencies such as NOAA (National Oceanic and Atmospheric Administration) to examine the cost effectiveness of remotely sensed data of different resolution.

Following this first activity we have proposed to combine physical data and models and economic data and models in a GIS (Geographic Information System) to evaluate the role of USGS in offshore environmental policy 
decisions. Some of the environmental policy issues that will be addressed include:

1. What physical information is important in managing a marine sanctuary?

2. Are bottom conditions part of the development of an offshore environmental policy?

3. Should we develop an oceans mass balance model (current, temperature, other physical variables) to evaluate offshore environmental risks, similar to terrestrial mass balance models?

4. Should the role of the Government be to provide site-specific or regional protocols for future rule-making offshore?

5. Who is responsible for identifying and verifying offshore dumpsites for radioactive and other toxic wastes?

6. What effects do sanctuaries and dumpsites have on decisions regarding utilization of the EEZ (Exclusive Economic Zone) for harvesting renewable resources, extraction of nonrenewable resources, and recreation?

7. How do we assign a value to endangered species in environmentally threatened areas offshore?

\section{REFERENCES}

Bernknopf, R.L., Brookshire, D.S., Soller, D.R., McKee, M.J., Sutter, J.F., Matti, J.C., and Campbell, R.H., 1993, Societal value of geologic maps: U.S. Geological Survey Circular 1111, 53 p.

Chavez, P.S., Jr., and Karl, H.A., in press, Detection of barrels on the seafloor using spatial variability analysis on sidescan sonar images: Journal of Marine Geodesy, Special Issue.

Karl, H.A., Schwab, W.C., Wright, A. St.C., Drake, D.E., Chin, J.L., Danforth, W.W., and Ueber, E., 1994, Acoustic mapping as an environmental management tool, I-Detection of barrels of low-level radioactive waste, Gulf of the Farallones National Marine Sanctuary, California: Ocean \& Coastal Management, v. 22, p. 201-227.

\section{Consequences of Energy Use on Water Quality}

\author{
Mary Jo Baedecker, William Back, and \\ Charles A. Cravotta, III, \\ U.S. Geological Survey, Reston, VA 22092
}

Practices for the production, distribution, and use of energy have had a significant impact on the quality of surface and ground water throughout much of the United States. For example, coal mining can affect water quality by the generation of acidic drainage from overburden and coal; improperly managed brines from oil and gas fields can increase the concentrations of total dissolved solids and toxic metals in fresh water; petroleum and petroleum-derived products from pipeline breaks, spills, and leaking storage tanks can contaminate streams and aquifer:; acidic leachate from waste rock and tailings piles can nobilize radionuclides and other metals; and hydroelectric power dams can affect upstream and downstream water quality and riparian ecology. The scientific problems associated with the deterioration of water quality and the policy and management initiatives to resolve these problems differ among the various energy sources.

Environmental research related to energy use includes studies to understand (1) the fate and behavior of products such as crude oil, coal, and byproducts such as tailings, in various hydrogeologic environments; (2) the effects of geochemical reactions, some of which are microbially mediated, on mineral stability and consequently on the inorganic chemistry of water; (3) the rates at which the controlling reactions occur; and (4) the integration of chemical reactions and microbial and physical processes into $f$ ow and transport models in order to determine the concentration of solutes at certain locations for times in the future.

\section{Changes in Water Quality}

Changes in the chemical composition of fresh water presented here resulted from production or use of coal, petroleum products, and uranium. A major environmental problem that affects the quality of surface anc' ground water is acidic drainage from the mining of coal and uranium. The oxidation of sulfide minerals, predominant'y pyrite, in overburden or tailings exposed from a mining operation produces acidic water that enhances the dissolution and mobilization of other metals. Upon exposure to oxygen and water, pyrite oxidizes and initially forms soluble ferrous iron, protons and sulfate (Kleinmann and others, 1981; Nordstrom, 1982). The chemical reaction that describes the comp'ete oxidation of pyrite is written as:

$$
\mathrm{FeS}_{2}+3.75 \mathrm{O}_{2}+3.5 \mathrm{H}_{2} \mathrm{O} \rightarrow \mathrm{Fe}(\mathrm{OH})_{3}+2 \mathrm{SO}_{4}=+4 \mathrm{H}^{+}
$$

These acidic weathering reactions are prevalent in the unsaturated zone and can form other iron-bearing minerals that temporarily store acid and sulfate, until wet conditions release the contaminants. The resulting low' $\mathrm{pH}$ of the water and the increase in metal concentrations from these oxidation-reduction reactions often harm organi $\mathrm{ms}$ in the stream and riparian zone. Not all acidic water is th: result of human activities. Also, not all mining results in acidic water. For example, carbonate rocks adjacent to coal seams can dissolve to generate bicarbonate that has a neu'ralizing effect on acid generation. Innovative mining method: and engineering practices have been developed to take actvantage of these reactions to minimize the effects on water quality.

The effect of coal mining on water cuality is variable and depends on the composition of the coa' and overburden, and the extent of mineral weathering alon? the flowpath of the water. At coal mining sites investigater' in Pennsylvania, 
the quality of water from surface mines reflects the composition and reactions associated with the minerals in the overburden that remains as mine spoil or backfill, whereas in underground mines the water quality reflects the composition and controlling reactions in the exposed coal pillars and surrounding rock (Cravotta, 1994). Surface mining and underground mining can generate very different chemical types of water.

One of the environmental effects of the generation of acidic water in tailings piles is the discharge of acidic leakage into aquifers and streams. At a site in Ontario, pyrite was oxidized in uranium tailings, and the acidic water infiltrated to the subsurface, with some of it discharging to a stream (Dubrovsky and others, 1984). The movement of $\mathrm{H}^{+}, \mathrm{Al}^{3+}$, heavy metals, uranium, and ${ }^{210} \mathrm{~Pb}$ through the tailings pile was retarded by geochemical processes, while $\mathrm{Fe}^{2+}$ and $\mathrm{SO}_{4}{ }^{2-}$ traveled at about the average linear ground-water velocity. Leachate from tailings piles is often controlled by treatment with lime and barium chloride, the latter added for precipitation of ${ }^{226} \mathrm{Ra}$ (radium). Much attention with respect to the environmental impact of uranium milling has focused on radium because it is a bone-seeking radionuclide and has a restrictive drinking water standard. Deposition of uranium mill tailings in anaerobic environments has been shown to have the potential for the release of ${ }^{226} \mathrm{Ra}$ to contacting waters by microbial processes (Landa and others, 1991). ${ }^{226} \mathrm{Ra}$ may also be a concern in water collecting in pits at abandoned surface uranium mines, as well as in water discharged from active, underground uranium mines (Longsworth, 1994).

The production and use of natural gas, petroleum, and petroleum products can affect (1) the inorganic composition of fresh water because of mixing with brines from gas and oil wells or test holes and (2) the organic composition of water because of contact with a nonaqueous phase liquid, such as gasoline or crude oil. Many processes such as microbially enhanced degradation, sorption, and photooxidation can occur when organic compounds are transferred to the aqueous phase. These processes affect the chemistry of the water, and the mineralogy and hydraulic conductivity of the aquifer matrix.

The most soluble components of petroleum products are benzene, toluene, ethylbenzene, and the xylenes (BTEX); these volatile compounds are among the 25 most frequently reported contaminants at hazardous waste sites. The compounds BTEX can migrate from source areas and become inaccessible for cleanup from aquifers. However, these compounds are known to be biodegraded by a number of aerobic and anaerobic pathways, which makes their removal more feasible than that of other contaminants such as chlorinated solvents. Other components of petroleum products, such as aliphatic hydrocarbons, may come in contact with water by a spill or leaking tank. Because these hydrocarbons are relatively insoluble, they do not migrate far but remain close to the source area. At a site in Minnesota where a pipeline carrying crude oil ruptured, a long-term study indicated that the movement of the contaminan' plume was stabilized by biodegradation of the soluble components of the crude oil (Baedecker and others, 1993). The movement of BTEX at concentrations above Federal standards for drinking water was restricted to an area of less than $200 \mathrm{~m}$ downgradient of the source, although the ground-water velocity was high enough to have carried the contaminants much farther. However, there is so much crude oil in the subsurface that the plume will remain for a long time, $a^{-1}$ as the biogeochemical processes change, the plume also may change.

\section{Societal Needs and Expectations}

People are concerned about water quality becanse it is a resource worthy of preservation and because the de line in water quality can affect the health of humans and tre wellbeing of the biota. Advances in the scientific knowledge of the behavior of contaminants in the environment have shown that it is more effective to prevent and control contars ination than to clean up the results of poor disposal practices or accidental discharges. For organic contaminants, cleanup in subsurface environments where oxygen is limited is slow'er than in surface water where photooxidation and volatilization of organic contaminants can be significant removal mechanisms. Biotic and abiotic processes can degrade orgar ${ }^{i} \mathrm{c}$ contaminants to other compounds, including $\mathrm{CO}_{2}$ and $\mathrm{CH}_{4}$, which are end products of reactions involving carhon. In contrast, the result of any process does not change t $?$ mass of a metal, but can change its chemical speciation and mobility. Major advances have been made to improve water quality by preventing the mixing of contaminated water with fresh water and by using remediation techniques to is late or attenuate contaminants. Still, the quality of water for the future is uncertain because human activities continue to cause contamination of water and because the proces?es that determine whether contaminants can be removed from hydrologic environments are not clearly understood.

\section{REFERENCES}

Baedecker, M.J., Cozzarelli, I.M., Eganhouse, R.P., Siegel, D.I., and Bennett, P.C., 1993, Crude oil in a shallow sand and gravel aquifer-III, Biogeochemical reactions and mass balance modeling in anoxic ground water: Applied Geochemistry, v. 8, p. 569-586.

Cravotta, III, C.A., 1994, Secondary iron-sulfate minerals as sources of sulfate and acidity, in Alpers, C.N., and Blowes, D.W., eds., Environmental geochemistry of sulfide oxidation: ACS Symposium Series 550, American Chemical Society, Chapter 23, p. 345-364.

Dubrovsky, N.M., Morin, K.A., Cherry, J.A., and Smyth. D.J.A., 1984, Uranium tailings acidification and subsurface contaminant migration in a sand aquifer: Water Pollution Fesearch Journal of Canada, v. 19, no. 2, p. 55-89. 
Kleinmann, R.L.P., Crerar, D.A., and Pacelli, R.R., 1981, Biogeochemistry of acid mine drainage and a method to control acid formation: Mining Engineering, v. 33, no. 3, p. 300-304.

Landa, E.R., Phillips, E.J.P., and Lovley, D.R., 1991, Release of ${ }^{226} \mathrm{Ra}$ from uranium mill tailings by microbial Fe(III) reduction: Applied Geochemistry, v. 6, p. 647-652.

Longsworth, S.A., 1994, Geohydrology of abandoned uranium mines and radiochemistry of spoil-material leachate, Monument Valley and Cameron areas, Arizona and Utah: U.S. Geological Survey Water-Resources Investigation Report 93-4226, $43 \mathrm{p}$.

Nordstrom, D.K., 1982, Aqueous pyrite oxidation and the consequent formation of secondary iron minerals, in Kittrick, J.A., Fanning, D.S., and Hossner, L.R., eds., Acid sulfate weathering: Soil Science Society of America, Special Publication 10, Fort Collins, Colorado, 1979 [Proceedings], p. 37-56.

\section{A Little Learning is a Dangerous Thing- But How Do We Apply Our Geoscience Knowledge to the Regulatory Process?}

\section{Lorraine H. Filipek and James K. Otton, U.S. Geological Survey, Denver, CO 80225}

One primary focus of this year's McKelvey Forum is the USGS Energy Program-the types of information we collect and research we conduct in order to identify the quality as well as the quantity of fossil fuels. We are building the scientific knowledge and databases that allow policy makers and regulators to know the different kinds of fuel resources this Nation has, their distribution, the environmental consequences of their extraction and utilization, and the scientific uncertainties that exist within the limitations of the available scientific data. This information is needed to help the Nation develop policy concerning the use of these resources. In order to be as effective as possible in the regulatory process, regulators need to know about the kinds of information we have, and USGS scientists need to know more about the kinds of information that will be most useful for the regulatory process and how and when to supply it to the regulators.

This Forum is part of our information-transfer process. In this final oral presentation, we give examples of how the USGS has contributed scientific information to the regulatory process and mention some of the issues that are likely to be important in the next few years. We concentrate on two elements of the energy environmental program structure: environmental effects of natural energy occurrence and impacts of energy extraction.

\section{Natural Occurrence-The Background Problem}

The "background" level-the amount of a substance present naturally - is a concept of great health and monetary importance when it comes to land-use planning, regulating industrial discharges, or cleaning up "contamination." In many places, background levels of natural", occurring substances such as hydrocarbons, trace metals or radionuclides may exceed regulated levels or levels from manmade sources. In some cases, natural levels can present health hazards. For example, epidemic numbers of people in certain areas of what was once Yugoslavia have died from kidney failure. The USGS discovered that the ground water used by these people for drinking water contained high concentrations of organic compounds that leached naturally from lignite coalfields. Now, treatment of the ground water will significantly reduce deaths by kidney failure.

In other cases, health data are inconclusive on hazardous levels of elements and compounds. In these cases, an overly conservative approach can be extremely costly. For example, radon in air is a known heal'h risk; however, radon in water has no known health risks, other than the potential to degas minor amounts of radon into the air. In spite of this, as part of the Safe Drinking Water Act, EPA is required to set regulatory limits for levels of radon in drinking water. Presently discussed minimum contaminant levels (MCL's) are on the order of 300 picocuries/liter. When nuclear energy was corsidered a major potential source of energy, the USGS conducted research on the geochemistry of uranium-bearing rocks. Radon is a daughter product of the natural radioactive decay of uranium and thorium, so we also studied radon. This research indicates that the proposed MCL is 10-100 times less than typical ground-water background levels in crystalline-rock aquifers. Thus, many water districts will be forced to spend large sums to treat natural ground water to obtain levels of radon in compliance $w^{i t h}$ the proposed standard.

Our research on uranium geology h's allowed us to help in another arena-that of indoor radon pollution. Considerable geographic variability exists in the concentrations of radon emitted naturally from soils. This variability is related to the soils' varying ridiochemical and physical properties. The USGS, several State agencies, and other interested groups have developed techniques for mapping geologic radon potential and have mapped the entire United States at varying levels of detail. These maps are designed to focus attention towards areas of higher radon potential, to show areas where recommended modifications to building codes to lower radon entry in new housing should be applied, and to encourage sampling of existing housing. As such these geology-based maps contribute to the policy goal of reducing human exposure to indoor radon.

A substantial number of legal battles have been fought over whether existing contamination in a particular area is due to human activity or is a natural result of geologic circumstances. Data the USGS collects during assessment and research studies lave commonly 
determined sources of contamination in certain localities. The utility of background information has prompted State regulatory agencies to work with us both in developing improved data-collection requirements for permitting, and in requiring technical specifications based on known problems in specific geologic environments.

For example, the New Mexico Oil Conservation Division has used our studies on the molecular and isotopic composition and origin of natural gases in the San Juan Basin both to remediate and to prevent contamination of shallow aquifers by natural gas, mainly methane. The San Juan Basin has been an area of considerable oil and gas development and production since the 1950's. Most recently, active development of coalbed methane from the Upper Cretaceous Fruitland Formation has taken place within the basin, which has coincided with reports of natural gas in water. Our studies have shown that some of the contamination has resulted from vertical migration of natural gas behind the casing of wells producing from this formation and from devices installed to prevent corrosion of casing in gas wells. However, some of the gas in the shallow aquifers was formed naturally in-place by anaerobic microorganisms. As a result of our studies, remedial action was taken for several wells in the New Mexico part of the basin, and standards were developed for future well completions to protect the shallow aquifer.

\section{Energy Extraction-What to Do With the Waste?}

Waste management is arguably the most significant environmental issue related to energy (or any other industry!). It is the heart of most environmental regulation including RCRA, CERCLA, the Clean Air and Water Acts, and the Safe Drinking Water Act. Sulfur, acid, salt, trace elements, naturally occurring radioactive materials (NORM), and gases, including carbon dioxide, can be released into the environment during energy extraction and utilization. We are developing methods to predict waste characteristics, to determine the geologic factors that contribute to the suitability and durability of potential waste repositories, to map existing waste contamination, and to develop effective remediation strategies.

For example, coal extraction wastes can produce environmental problems. Acid mine drainage (AMD) caused by coal mining activities has been cited as one of the main reaons for the Surface Mining Control and Reclamation Act of 1977. However, initial regulations developed by the Office of Surface Mining (OSM) under the Act were based on a limited amount of information. As a consequence, AMD continues to be a serious problem associated with coal mining in the Eastern United States. Ve are currently working with OSM, U.S. Bureau of 'Yines, the National Mined Lands Reclamation Center, and State regulatory agencies in an informal consortium to improve the coal-mine permitting process in the App lachian area. We are developing conceptual geologic models of coal and overburden and are testing geophysical techniques to develop innovative and cost-effective AMD prediction methods. We are combining our knowledge of local geologic and geochemical variability in coal-forming environments with statistical methodology to detexmine the minimum number of samples necessary to adequately characterize a prospective site. We are also forming partnerships with the U.S. Bureau of Mines, based on our complementary expertise, to develop row and improved technologies, such as anaerobic bioreact ors, to treat AMD.

Oil and gas drilling operations may produce brine wastewaters that contain NORM. Louisiana, Arkansas, and Mississippi have developed regulations to control soil contamination from NORM in the wastewaters, and other States are considering regulations. EPA is conducting preregulatory studies of the issue. The USGS is investigating the extent of NORM and related trace-metal contamination associated with oil and gas production by evaluating available published data sets, evaluating soil surveys for evidence of salt scarring, and assisting States in radiometric site characterization. These studies should assist Federal and State authorities in developing appropriate regulations for new drilling and in identifying and reclaiming sites contaminated from past activities, assist companies in evaluating environmental liabilities associated with property acquisition, and provide cost-effective means for site characterization.

\section{The Future-Toward Sustainable Energy Development and Use}

One parting thought: According to legend, the oracle at Delphi warned, "A little learning is a dangerous thing***Drink deep or taste not the Pythian spring." If we approach a problem in ignorance, we will make poor decisions. Major roles of the USGS are to generate data in order to increase our understanding of geologic areas of pul ${ }^{\mathrm{lic}} \mathrm{c}$ concern, to transform the data into useful information, and then to communicate that information effectively to the p rblic and, in particular, to the writers of regulations. Relevant information is the basis for sustainable, environmentally acceptable energy development and use. We applaud flexibility in national regulations that allow State/local authorities to take into account local conditions but that offer guidelines sufficient to protect the environment uniformly across the country. We want to work even more closely w'ith policy makers at the national level to provide them the information they need to develop appropriate flexibility in ervironmental regulations related to energy commodities, and with regulators at the State/local level to develop strategies for regulatory compliance that are based on science. We ask your help in becoming more effective. 


\title{
PAPERS CONCERNING POSTERS— ARRANGED BY PROGRAM THEME
}

\author{
Information Transfer
}

\section{Easy Access to Coal Quality Information: COALQUAL_The New USGS Coal Quality CD-ROM Database}

\author{
Linda J. Bragg, Charles L. Oman, \\ Susan J. Tewalt, and Robert B. Finkelman, \\ U.S. Geological Survey, Reston, VA 22092
}

A new CD-ROM (Compact Disc-Read Only Memory) was produced to satisfy a demand for access to the USGS's (U.S. Geological Survey) USCHEM (USgeoCHEMical) database by coal mining companies, utilities, State agencies, environmental organizations, researchers, and others. In addition, the USGS's coal quality data were adopted by the U.S. Environmental Protection Agency (EPA) to address the effects of the 1990 Clean Air Act Amendments (CAAA). That recognition of the USGS data created an additional demand for public access to the database.

A subset of data, representing the 50 most productive U.S. coal beds during 1990, was selected for the EPA by USGS personnel from the coal quality information contained in the USGS's National Coal Resources Data System (NCRDS) to fulfill this requirement. The EPA is obligated to assess the impact of 189 chemical substances from a wide variety of stationary sources, including emissions from electric utility steam generating plants. The limitations in time and money, plus the lack of appropriate analytical methods, have severely curtailed field testing activities. Therefore, the EPA has sought out existing databases that contain fuel analysis information.

To meet this need the USGS has released a CD-ROM (Bragg and others, 1994) that contains comprehensive information representing approximately 7,400 full-bed U.S. coal samples compiled from the 13,035 full-bed and benched coal and rock samples that compose the USCHEM database. For some localities, data are represented by one sample obtained either by channel or core (Swanson and Huffman, 1976; Stanton, 1989). In other localities, because the only available data were either bench or interval samples, a composite sample was calculated. A composite sample entailed calculating values from the weighted averages of interval (bench) samples taken sequentially to represent the bed thickness. (Weighted averages are calculated by normalizing the data to the total "bed thickness" using the individual sample thicknesses.) Up to 136 parameters are available for each sample record. These parameters include (1) geologic, stratigraphic, and geographic data; (2) ultimate and proximate data; (3) forms of sulfur; (4) grindability and free-swelling indices;
(5) ash fusion temperatures; (6) calorifi: values; (7) ash oxides; and (8) concentrations of 63 major, minor, and trace elements. The chemical data are presented on a whole-coal, as-received basis, except for the oxides, which are presented on an ash-basis. ASTM (American Society for Testing and Materials) standards were used to test for parameter groups 2-6 through agreements with the USBM (U.S. Bureau of Mines) testing lab and commercial labs: USGS methods were used for parameter groups 7 and 8 (Swanson and Huffman, 1976; Golightly and Simon, 1989).

Table 1, sample distribution by coal province, coal region, and State, shows a comparison of $t / 9$ number of samples in the USCHEM database and the number of samples in the COALQUAL database after restricting the samples in USCHEM to those representing full-bed coal samples. Figure 1 shows the geographical distribution. In addition to the database, technical information and publi ations pertaining to the data, sampling techniques, and analytical methods are also included on the CD-ROM. (See Finkelman and others, 1994; Golightly and Simon, 1989; Swanson and Huffman, 1976; USGS, 1976; and Wood and others, 1983.)

The USGS CD-ROM Open-File Report (Bragg and others, 1994) has been produced in accordance with the ISO 9660 CD-ROM Standard and is, therefore, compatible with any computing platform that has appropriate CD-ROM driver software installed. However, the access software (called GSSEARCH) used to retrieve dati on the disc currently executes only under DOS on IBM or compatible personal computers. A dBase file coalqual.dbf is included on the CD-ROM which may be downloaded to a IBM compatible $\mathrm{PC}$ and accessed by a variety of databases that can import dBase (version 3.0 or higher) files. Date may be selected through the use of GSSEARCH and output in a variety of formats, including dBase, flat ASCII, de'imited ASCII, or fixed-field for use on other computing platforms.

The CD-ROM provides easy access to data representing full-bed coal samples and is available to the public through the USGS. Much of the data war obtained prior to 1982 , and as a consequence, many of the coal samples were obtained from areas that are now mined out or where coal mining has subsequently ceased. On the average, only 100 analyses are being added to the USCHE' 1 database annually. The CD-ROM will enable the user to look at regional projections of coal quality variation; how?ver, care must be exercised when looking at areas in detail. Care must also be taken in using data for elements where mcre than 10 percent of the non-zero data were qualified in th: USCHEM database (this information is found in the he'n files and in the techinfo documentation on the CD-ROM). Non-zero 
Table 1 (Bragg and others). Samples in USCHEM and COALQUAL databases from coal-bearing areas.

$[-$, no sample]

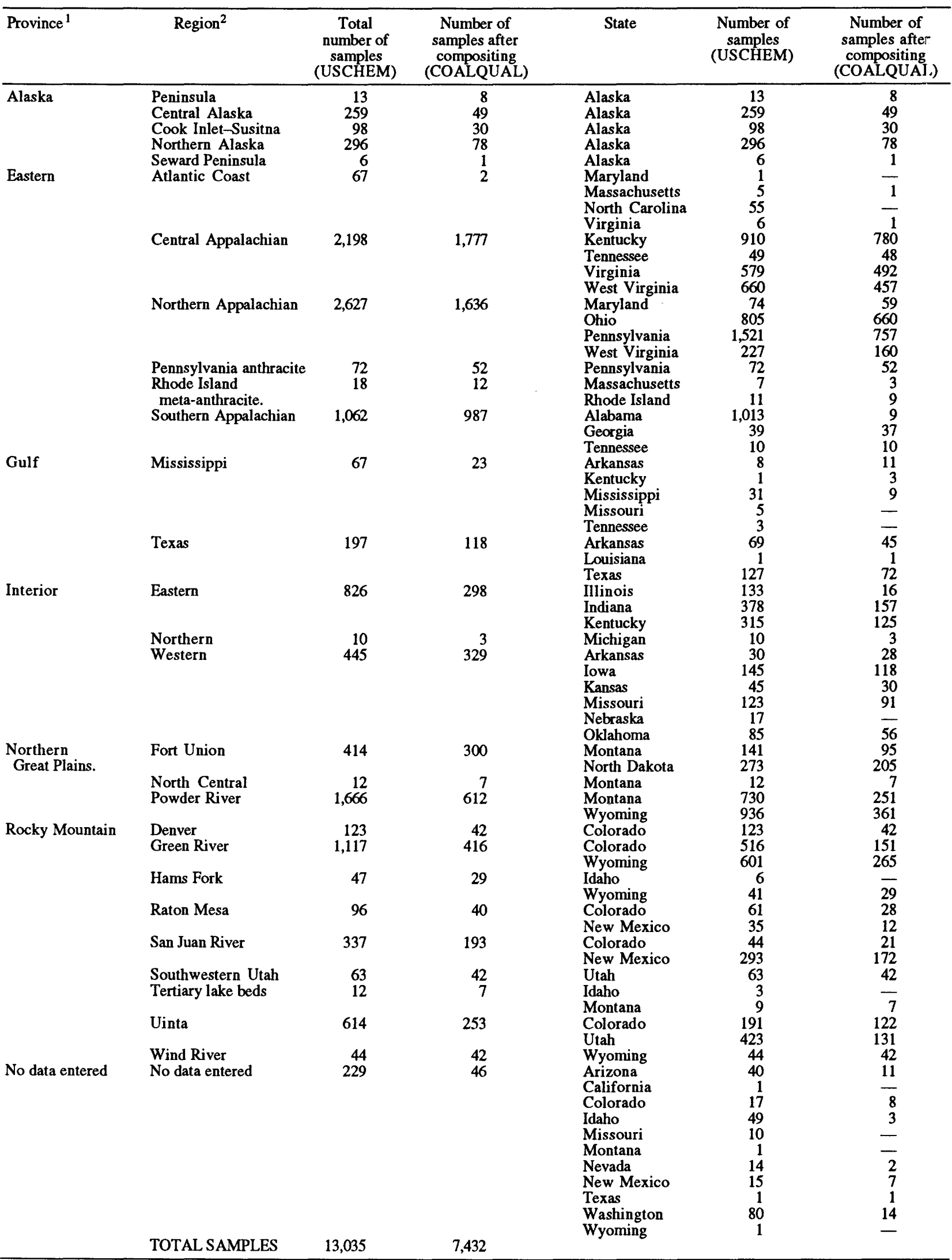

\footnotetext{
${ }^{1}$ Source: Wood and others (1983, p. 16).
}

${ }^{2}$ Modified from Wood and others (1983, p. 15); Appalachian region is split into Northern, Central, and Southern Appalachian. 


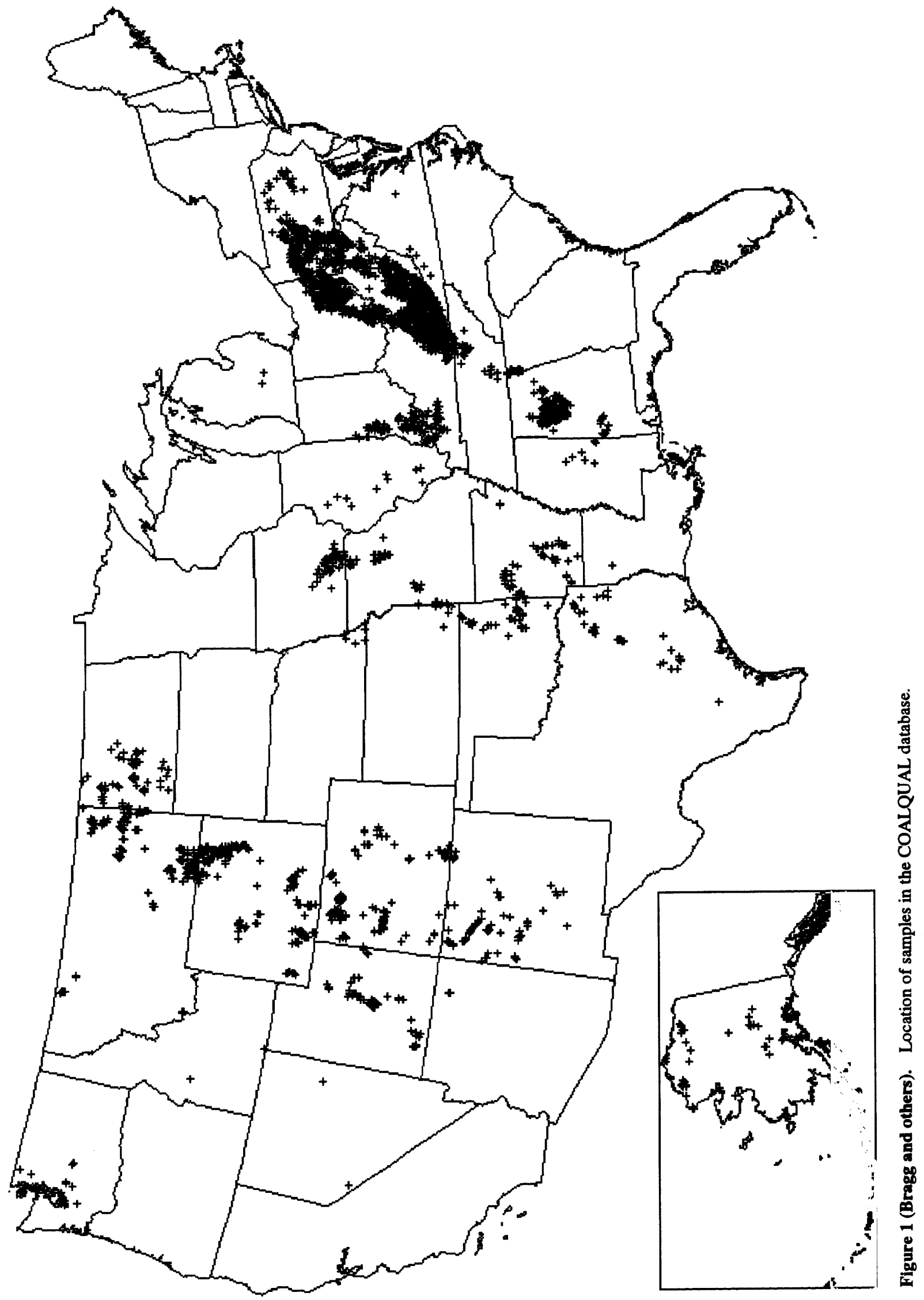


qualified data are values which are greater than (G) or less than (L) the detection limit for the element. Qualified data having qualifiers of B (not analyzed for), $N$ (not detected), and $\mathrm{H}$ (interference) are treated as zero qualified data or NULL values. All the chemistry data have been validated - the data in the database have been corrected to the analytical data sheets. By the end of 1995, the geologic, stratigraphic, and geographic data should be completely validated (sent to the collectors where possible or checked against publications) and corrected in the database, at which time a new version of the CD-ROM is anticipated. The USGS will continue maintaining the USCHEM and COALQUAL databases and adding data as acquired.

\section{REFERENCES}

Bragg, L.J., Oman, J.K., Tewalt, S.J., Oman, C.L., Rega, N.H., Washington, P.M., and Finkelman, R.B., 1994, U.S. Geological Survey coal quality (COALQUAL) database; version 1.3: U.S. Geological Survey Open-File Report 94-205 (CD-ROM).

Finkelman, R.B., Oman, C.L., Bragg, L.J., and Tewalt, S.J., 1994, U.S. Geological Survey coal quality data base (COALQUAL): U.S. Geological Survey Open-File Report 94-177, 46 p.

Golightly, D.W., and Simon, F.O., 1989, Methods for sampling and inorganic analysis of coal: U.S. Geological Survey Bulletin $1823,72 \mathrm{p}$.

Stanton, R.W., 1989, Sampling of coal beds for analysis, in Golightly, D.W., and Simon, F.O., eds., Methods for sampling and inorganic analysis of coal: U.S. Geological Survey Bulletin 1823 , p. 7-13.

Swanson, V.E., and Huffman, Jr., A.C., 1976, Guidelines for sample collecting and analytical methods used in the U.S. Geological Survey for determining chemical composition of coal: U.S. Geological Survey Circular 735, 11 p.

U.S. Geological Survey, 1976, Coal resource classification system of the U.S. Bureau of Mines and U.S. Geological Survey-Mineral resource classification systems of the U.S.B.M. and U.S.G.S.: U.S. Geological Survey Bulletin $1450-B, 7$ p.

Wood, Jr., G.H., Kehn, T.M., Carter, M.D., and Culbertson, W.C., 1983, Coal resource classification system of the U.S. Geological Survey: U.S. Geological Survey Circular 891, 65 p.

\section{CD-ROM Publication of the}

\section{National Assessment of Oil and Gas Resources of the United States}

\author{
Ken Takahashi and Donald L. Gautier, \\ U.S. Geological Survey, Denver, CO 80225
}

The results of the 1995 National Assessment of Oil and Gas Resources of the United States are presented in an interactive CD-ROM. The application of new digital technologies to the publication of data and the presentation of findings from this major program of the U.S. Geological Survey has resulted in a unique product that presents the complex procedures and findings in a form that is clear and understandable to the lay person. At the same time the use of digital technology preserves and makes available the data and maps used in the assessment in a digital form useful to the scientific community. The interactive nature of the National Assessment CD-ROM allows the user tc browse through the documents and presentations, choosing items of interest in user-selectable order. Using digital techniques to present the findings and methodology provides the opportunity to illustrate and present complex concepts and relationships in graphic images or animations that are easy to understand.

Knowledge of oil and gas resources is necersary for strategic planning, evaluating Federal lands, and de ${ }^{\prime}$ eloping sound economic, energy, and environmental policies. The U.S. Geological Survey (USGS), in collaboration with the Minerals Management Service (MMS), is the only independent body able to conduct such a study. The USGS National Assessment is an unbiased and scientifically based estimate of the quantity of oil and gas yet to be discovered and of the past and future growth in hydrocarbon reserves. The National Assessment describes the sources of oil and gas, where they are, what technology may be needed to recover them and at what price, and at what rate they can be withdrawn. This more comprehensive view of the National Assessment will provide a new understanding of U.S. oil and gas resources.

Selection of CD-ROM as the medium for presenting the results of the 1995 National Assessment of Oil and Gas Resources was based on its characteristics and capabilities. Currently CD-ROM's are the only medium capable of holding the volume of data necessary to present the findings and supporting information of the assessment. The C?-ROM medium can be read by nearly every operating system due to its industry-wide standard format and is rapidly becoming the medium of choice for the publication and dissemination of data. This allows for a single publication of the results in a form compatible with the two most popular persoral computing platforms. The information on the data archive volume will be compatible with nearly all computer systems with a CD-ROM drive.

The design of this program allows the user to view the findings of this program from several different persrectives. The first follows the analogy of a traditional paper publication in which text and illustrations are read and viowed in serial order, with the user proceeding from start to finish a page at a time. The work can also be viewed from a spatial or map-oriented perspective with selections made from an index map to view text and graphics from a geograrhic perspective. Finally, animated, historical views of oil and gas exploration over time are available for each of the provinces, taking advantage of the computer's capabilities. 
The CD-ROM was developed using Macintosh, PC, VAX, and Data General systems linked by local and wide area networks. VAX systems processed data from NRG Associates, Inc., and Petroleum Information, Inc., databases with Ingres and Dynamic Graphics software. Maps developed in an Aviion/ARC/INFO environment were imported to Macintoshes using Apple Mac X, Adobe Illustrator, and PhotoShop. Charts were developed on Macintoshes using Delta Graph Pro 3, Deneba Canvas, and Microsoft Excel. Text was edited with Microsoft Word and Word Perfect. The CD-ROM was authored on Macintoshes with Macromedia Director and ported to Windows.

The National Assessment CD-ROM is designed to run on both Apple Macintosh and Windows-based PC systems for broadest usage. This digital publication will also be made available on the Internet for downloading along with the accompanying digital data files and map coverages.

\section{Geological and Geophysical Information from the National Petroleum Reserve Alaska on CD-ROM as a Tool in Support of Geoscientific Decision-Making}

\section{David J. Taylor and Frederick N. Zihlman, U.S. Geological Survey, Denver, CO 80225}

In light of today's concerns over energy supplies and the impact that exploration for and production of these resources has on the environment, it is critical that explorationists, production companies, and land-use planners have all pertinent geoscientific data at their fingertips. Often the data needed to formulate policy are not available from a single source and are not on media which are easily accessible using today's computer technology. Putting a vast amount of closely related data on a single high-density lowcost medium can be accomplished now, thanks to the development of CD-ROM (Compact Disk-Read Only Memory) data storage technology.

In 1977, jurisdiction of the Naval Petroleum Reserve Alaska (NPRA) was transferred to the U.S. Geological Survey from the U.S. Navy Department, charging the USGS with responsibility for (1) exploring the area for oil and gas and compiling a database for assessing the NPRA's petroleum potential; (2) supplying natural gas to the residents of Barrow, Alaska, and local government facilities; and (3) restoration of areas that were disturbed during construction and petroleum exploration activities into an environmentally acceptable condition. As a result of this charge, the USGS has a large amount of seismic reflection, well-log, geochemical, stratigraphic, biostratigraphic. and well-core data from the NPRA. This region is extremely prospective for future oil and gas development, yet it is in an ecosystem which is highly sensitive to environmental change. The USGS Energy Resource Surveys Program recognizes the importance of the data it holds in this are and is taking steps to ensure that all these data are preserved and made accessible to other government agencies, academia, industry, and the general public, in a cohesive unit on a longlasting, high-density, easily readable mecium in widely acceptable digital formats. These data are row being cataloged and transcribed onto CD-ROM's that are accessible using low-cost IBM-compatible, Apple I Tacintosh, and UNIX workstations. The idea behind this CD-ROM product is to gather all the data together from different digital and nondigital sources and compile them all onto a single medium as part of the Energy Resource Surveys Program information and technology transfer effort.

As a test of our capability to produce integrated geophysical and geologic data, the Energy Resource Surveys Program has developed a special CD-ROI 1 product containing available geophysical, geologic, borehole, biostratigraphic, and geochemical data pertaining to the Tunalik No. 1 well site, located in the far northwert corner of the NPRA (fig. 1). These data are a relatively complete set of exploration data that would assist explorat in, production, and ecosystem managers in creating land-development plans for the area.

This CD-ROM contains digital data in industry standard format, scanned digital images of originally nondigital data in standard graphics format, and software to display the data on IBM-compatible, Apple Macin ${ }^{+}$sh, and UNIX hardware. The digital graphics images can be displayed using low-cost commercially available gra ${ }^{2}$ hics programs capable of running on the hardware platforms mentioned. The seismic data include final stack data in SEG-Y format, digital shotpoint location data, seismic acq 'isition parameters, and seismic-processing parameters. Te well-log data include digital well-log data, digital imags s of well core, drilling history reports, depths to selected horizons, digital synthetic seismograms, original logging reports, lithologic reports, original sidewall core descriptions, and original core descriptions. The velocity data include digital depth, interval velocity, and average velocity information from the Tunalik No. 1 well and regional velocity information in digital form. ASCII files containing digital gravity measurements and gravity station locations in latitude and longitude will be included. Biostratigraphic data will include scanned images of the original palynology and foraminifera reports from the Tunalik No. 1 well.

The ultimate goal of this project is to transcribe a majority of our NPRA data onto CD-ROM and then to make these CD-ROM's available to the general public through the National Energy Research Seismic Library 


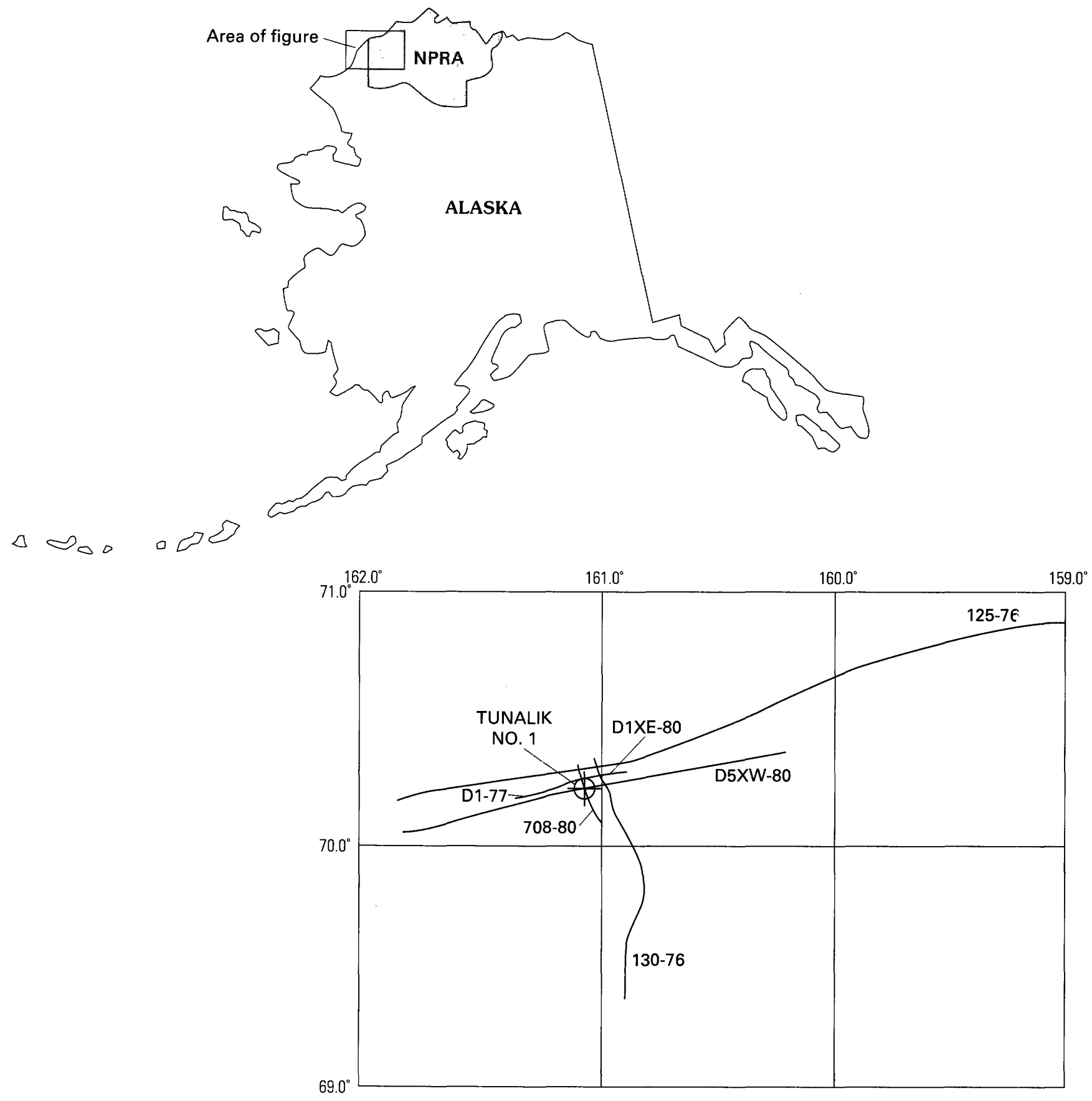

Figure 1 (Taylor and Zihlman). The Tunalik No. 1 well relative to the NPRA boundary, and the location of the surface seismic reflection data. The Tunalik No. 1 well drilled through more than 6,096 meters $(20,000 \mathrm{ft})$ of sedimentary section.

(NERSL). Ultimately, NPRA data along with digital seismic data from other regions will then be available through a number of distribution media, including data on CD-ROM, 9-track and 8-mm magnetic tape, paper hard copy reports, and on-line service that will allow digital information to be downloaded from a USGS server. We expect that making all of our nonproprietary data accessible will take several years to complete, but re will attempt to make subsets of the complete dataset available as soon as cataloging and archiving are accomplishet. 


\section{Availability and Quality of Energy Resources \\ Domestic Conventional}

\section{Cretaceous and Tertiary Coals and Coal- Bearing Rocks of the Western United States- A Bibliography of U.S. Geological Survey Data for Resource Estimation, Quality Determination, and Reclamation Potential Evaluation}

\author{
Ronald H. Affolter and Joseph R. Hatch, \\ U.S. Geological Survey, Denver, CO 80225
}

Extensive economic coal deposits occur in rocks of Cretaceous and Tertiary age in the Western United States. The coal-bearing rocks range from several hundred to greater than 10,000 feet thick and they contain some of the thickest coal beds in the United States. More than 50 percent of remaining identified U.S. coal resources lie in the Western States (Averitt, 1975), and 9 of the top 10 coal-producing mines are located west of the Mississippi River. In 1992 these nine mines produced over 158 million short tons of coal (Maclean Hunter Mining and Construction Group, 1993). These coals usually are low in ash ( $<10$ percent) and low in sulfur ( $<1.0$ percent) content. Apparent rank of most Cretaceous coals ranges from lignite A to anthracite; apparent rank of most Tertiary coals ranges from lignite A to subbituminous $\mathrm{A}$.

Since the early 1970's, the U.S. Geological Survey, in cooperation with other Federal agencies (such as Bureau of Mines, Bureau of Reclamation, Bureau of Indian Affairs), State geological surveys, industry, and academia, has collected, evaluated, and published data from many of the coalbearing regions of the Western United States (fig. 1). These publications cover the principal mined or minable Cretaceous-age coals of the Rocky Mountain province including those from the Black Mesa field (Arizona), Green River region (southwestern Wyoming and northwestern Colorado), San Juan River region (northwestern New Mexico and southwestern Colorado), and the Uinta region (eastern Utah and west-central Colorado). Publications on principal mined or minable Tertiary-age coals from the Rocky Mountain and Northern Great Plains provinces cover the Powder River and Fort Union regions of northeastern Wyoming, southeastern Montana, and western North Dakota. Publications on other Cretaceous and Tertiary coals cover the Bighorn region (northern Wyoming and southern Montana), Hams Fork region (southwestern Wyoming), Denver region (eastern Colorado), and Raton Mesa region (southeastern Colorado and northeastern New Mexico). Other publications are directed toward less significant coal-bearing areas (for example, Centralia-Chehalis coal district) of the Pacific Coast province (California, Oregon, and Washington).
U.S. Geological Survey publications rolevant to westem coals can be grouped into six general overlapping categories: (1) reports summarizing exploratcry drilling, (2) geologic maps, (3) EMRIA reports (Energy Mineral Rehabilitation Inventory and Analysis), (4) $\cos ^{1}$ resource estimates, (5) coal chemical composition and ut: lization, and (6) geologic studies.

1. Reports summarizing exploratory drilling contain location maps, drilling logs, detailed litholc sic descriptions of cored intervals, geophysical logs, coal $\mathbf{l} \otimes d$ correlations, and, in some cases, proximate and ultimate analyses of the coals, and the element compositions of selected coal and coal-associated rock samples.

2. Maps include (a) geologic maps of coal-bearing rocks; (b) Coal Development Potential maps (also called Known Recoverable Coal Resource Areas: KRCRA's are compiled to support land-planning by the Bureau of Land Management); (c) Coal Investigation maps that characterize coal deposits with geologic maps and detailed coal sections; and (d) miscellaneous field studies.

3. EMRIA (Energy Mineral Rehabili'ation Inventory and Analysis) reports (in cooperation witl the Bureau of Reclamation) provide descriptions and analyses of coals, overburden and underburden rocks, vegetation patterns, and hydrology of selected areas in order to estimate area reclamation potential.

4. Coal resource publications include area maps, procedural summaries, and tabular informatior. Some of these reports include resource estimates generated from data stored within the National Coal Resources Data System (NCRDS).

5. Coal chemical composition and utilization reports include proximate and ultimate analyses, heat-of-combustion, forms-of-sulfur, and ash-fusion-ter neratures. Also included are statistical summaries of the $r$ sh contents and major-, minor-, and trace-element composit ins of coals and coal-associated rock samples. Because more than 75 percent of U.S. coal is consumed by utilities (Maclean Hunter Mining and Construction Group, 1993), the chemical composition of coal has become more of a concern for future utilization. Environmental concern over stack emissions from the combustion of coal has increased due to the 1980 Clean Air Act Amendment, which has identified several potentially hazardous air pollutants (HAP). These reports will provide valuable information in our efforts to minimize emissions of those elements and will alsc support efforts toward the proper disposal of coal-fired power plant bottom ashes, fly ashes, and sludges.

6. Geologic studies provide information on depositional environments, stratigraphic fromeworks, and geochemical and mineralogical compositions of coal and coal-bearing rocks. 


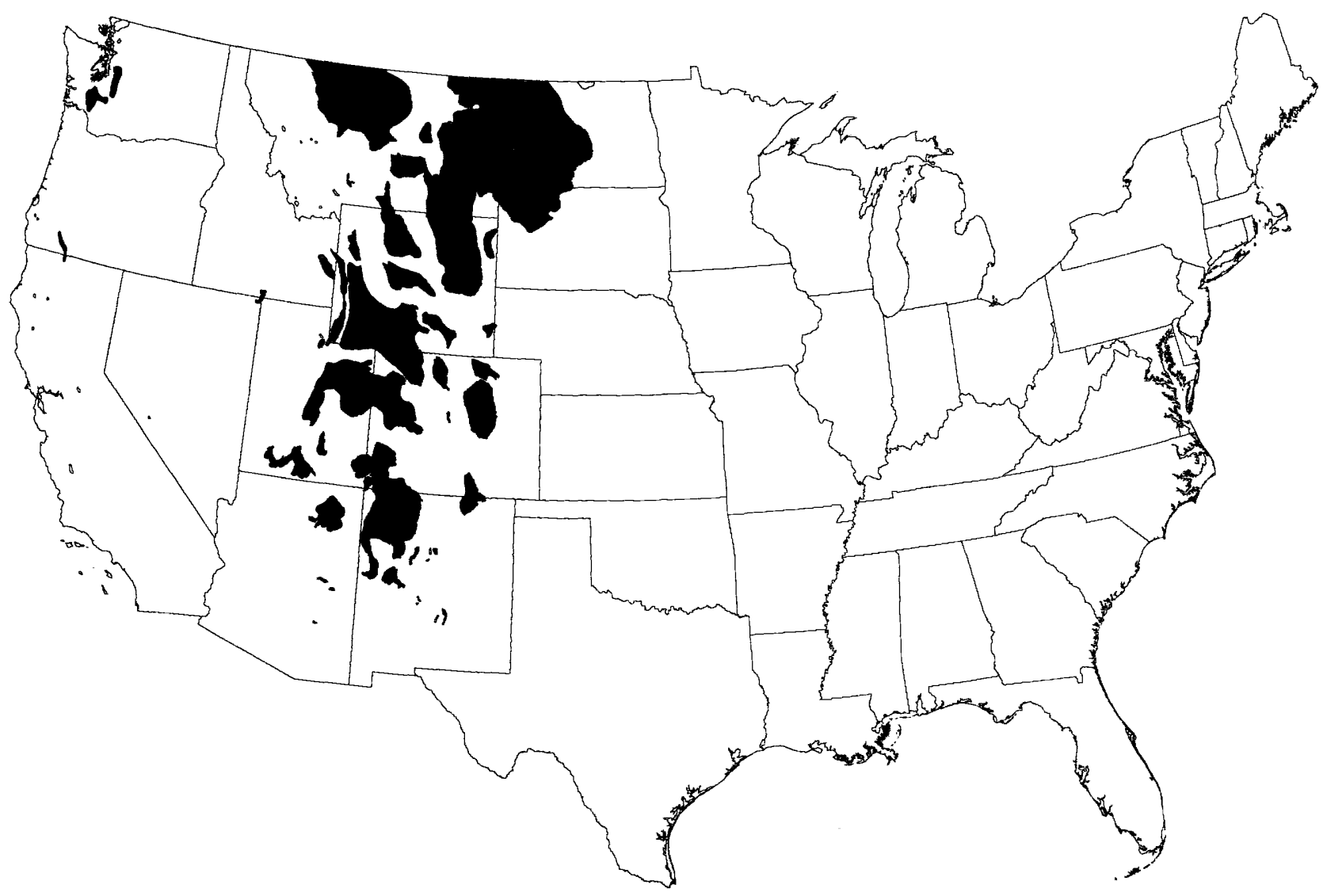

Figure 1 (Affolter and Hatch). Western coal regions. Map modified from Trumbull (1960).

Future development in Western U.S. Cretaceous and Tertiary coal-bearing areas will be assisted or constrained by the comprehensive geologic and analytical data contained in the more than 300 relevant publications of the U.S. Geological Survey. These data on Cretaceous and Tertiary coal and coal-bearing rocks in the Western United States will assist coal exploration and mining, coal utilization, and land-use planning, and help minimize environmental disruption resulting from mining and coal combustion.

An initial version of an annotated bibliography (containing reports published over the last 20 years) arranged by coal province, region, and subject will be available at the meeting. This bibliography will include maps showing the geographic areas covered by these publications.

\section{REFERENCES}

Averitt, Paul, 1975, Coal resources of the United States, January 1, 1974: U.S. Geological Survey Bulletin 1412, 131 p.

Maclean Hunter Mining and Construction Group, 1993, 1994 Keystone Coal Industry manual: Chicago, Ill., Maclean Hunter Mining Information Services, $656 \mathrm{p}$.

Trumbull, J.V.A., 1960, Coal fields of the United States, sheet 1: U.S. Geological Survey map, scale 1:5,000,000.

\section{The Future of Oil and Gas in Northern Alaska}

Kenneth J. Bird, Frances Cole, David G. Howell, and Leslie B. Magoon, U.S. Geological Survey, Menlo Park, CA 94025

The North Slope accounts for about 98 percent of Alaska's total oil production or about 1.6 MMBOP) (million barrels of oil per day). This production, along w'ith that from southern Alaska's Cook Inlet fields, makes Als ska the number two oil-producing State, contributing about 25 percent of the Nation's daily oil production. Cumulativ? North Slope production at year-end 1993 was 9.9 BBO (billion barrels of oil). Natural gas from the North Slope is not marketable for lack of a gas transportation system. Although enormous amounts of gas are produced with North Slope oil (cumulative production is about 20 TCFG, trillion cubic feet of gas), nearly all has been re-injected to maintain reservoir pressure and increase oil recovery. About 2 TCFG h's been used locally by the community of Barrow and for pow'er generation in the oil fields. At year-end 1993, Nortl Slope reserves were calculated at $6.1 \mathrm{BBO}$ ( 99 percent of State total) and 26.3 TCFG (92 percent of State total) ( Alaska, 1994). 
The North Slope is a lightly explored region containing one exploratory well per 270 square miles. Drilling began in the 1940's, when the U.S. Navy explored Naval Petroleum Reserve No. 4 and adjacent areas. This effort resulted in the discovery of several oil and gas fields of insufficient size for commercial development. Five years after the North Slope was opened to private oil exploration, the Prudhoe Bay oil field, North America's largest (12+ BBO ultimate recovery), was discovered in 1968. Regulatory uncertainty and construction of a 48 -inchdiameter pipeline stretching 800 miles southward to the Pacific Ocean at Valdez delayed the startup of Prudhoe oil production until 1977. By 1988, North Slope oil production from Prudhoe Bay and three other oil fields peaked at 2 MMBOPD; since then production has declined to the current rate of 1.6 MMBOPD in spite of six more oil fields coming into production (fig. 1). Undiscovered, economically recoverable oil resources, as of 1987, were estimated at 0-26 BBO (mean probability, 8 $\mathrm{BBO}$ ) for the onshore region and adjacent State waters by the USGS and 0-5 BBO (mean probability, <1 BBO) for the Federal offshore by the Minerals Management Service (Mast and others, 1989).

The North Slope is a high-cost area for oil and gas development because of the hostile environment, the remoteness from markets, and the lack of infrastructure. High costs account for the fact that less than one-third of the known oil and gas fields are producing and that gas is not marketable. They also account for the fact that only fields with high per-well production rates (rates that average two orders of magnitude higher than other U.S. producing regions: thousands vs. tens of BOPD) are currently being produced (Gerhard and others, 1988). When an economic screen is applied to USGS estimates of North Slope undiscovered oil resources, only 60 percent of those resources are considered economically recoverable (Attanasi and others, 1993). For example, the West Sak and Ugnu heavy oil accumulations with 20-40 BBO inplace, located between the Prudhoe Bay and Kuparuk River oil fields, are currently non-economic to produce.

An important factor affecting the future of existing North Slope oil fields and all future oil field development is the continued operation of TAPS (Trans-Alaska Pipeline System). A basic but unanswered question is the minimum throughput rate required for efficient, cost-effective operation. Studies by the U.S. Department of Energy (1991) have assumed a range of 400 to 200 MBOPD (thousands of barrels of oil per day) to illustrate the effects of a shutdown of TAPS. Using reserve and production rate numbers from existing fields, a TAPS shutdown is predicted for year-end 2008 assuming minimum rates of $400 \mathrm{MBOPD}$, and yearend 2014 assuming minimum rates of $200 \mathrm{MBOPD}$. Because the time between field discovery or decision-to-develop and first production is about 10 years, new or discovered fields may need to be brought into production by 1998 to assure continued operation of the pipeline.

Major North Slope environmental issues related to oil and gas include the loss of wetlands through gravel mining and placement, disturbance of subsistence 1 unting and fishing, and disruption of coastal flow patterns cr fish migrations by solid-fill causeways. Waste management will become increasingly important as fields mature and field shutdown approaches a reality (Thomas and others, 1973). North Slope operations are already under "zero discharge" regulations whereby all drillcuttings, mud, and other fluids are disposed of by injection into deep reservoirs. Other concerns include the threat of oil spills, disruption of fish and wildlife habitat, and pollution of air and water.

New technological developments applied to North Slope fields have reduced costs, improved oil recovery, and reduced environmental disturbance. More efficient equipment, improved field design, facilities sharing, and industry learning have, in some cases, reduced costs by as much as two-thirds (Harris, 1987). Ultimate oil re overy from the Prudhoe Bay field has increased from 9.6 BBO to about 12 BBO through the use of enhanced oil recovery techniques including waterflooding, miscible gas inje tion, fracturing, and horizontal drilling. Environmental disturbance has been reduced by siting production wells closer together, resulting in smaller gravel production pads, and by developing offshore fields from onshore sites by extended-reach drilling.

\section{REFERENCES}

Attanasi, E.D., Bird, K.J., and Mast, R.F., 1993, Economics and the national oil and gas assessment; The case of onshore northern Alaska: American Association of Petroleurn Geologists Bulletin, v. 77, no. 3, p. 491-504.

Gerhard, L.C., Graher, L.A., and Brostuen, E.A., 1988, A look at the status of U.S. petroleum: Oil and Gas Journal, June 20, 1988, p. 73-78.

Harris, M., 1987, Endicott benefits from lesscns learned: Alaska Construction and Oil, October 1987, p. 15-16.

Mast, R.F., Dolton, G.L., Crovelli, R.A., Root, L.H., Attanasi, E.D., Martin, P.E., Cooke, L.W., Carpenter, G.B., Pecora, W.C., and Rose, M.B., 1989, Estimates of undiscovered conventional oil and gas resources in the United States-A part of the Nation's energy endowment: U.S. Department of the Interior, $44 \mathrm{p}$.

Thomas, C.P., Allaire, R.B., Doughty, T.C., Faulder, D.D., Irving, J.S., Jamison, H.C., and White, G.J., 1993, Alaska North Slope national energy strategy initiative-Analy:is of five undeveloped fields: U.S. Department of Energy, DOE/ID/01570-T164.

State of Alaska, 1994, Historical and projected oil and gas consumption: Anchorage, Alaska Department of Natural Resources, Division of Oil and Gas, 61 p.

U.S. Department of Energy (DOE), 1991, Alaska oil and gasEnergy wealth or vanishing opportunity?: DOE/ID/01570-H1. 


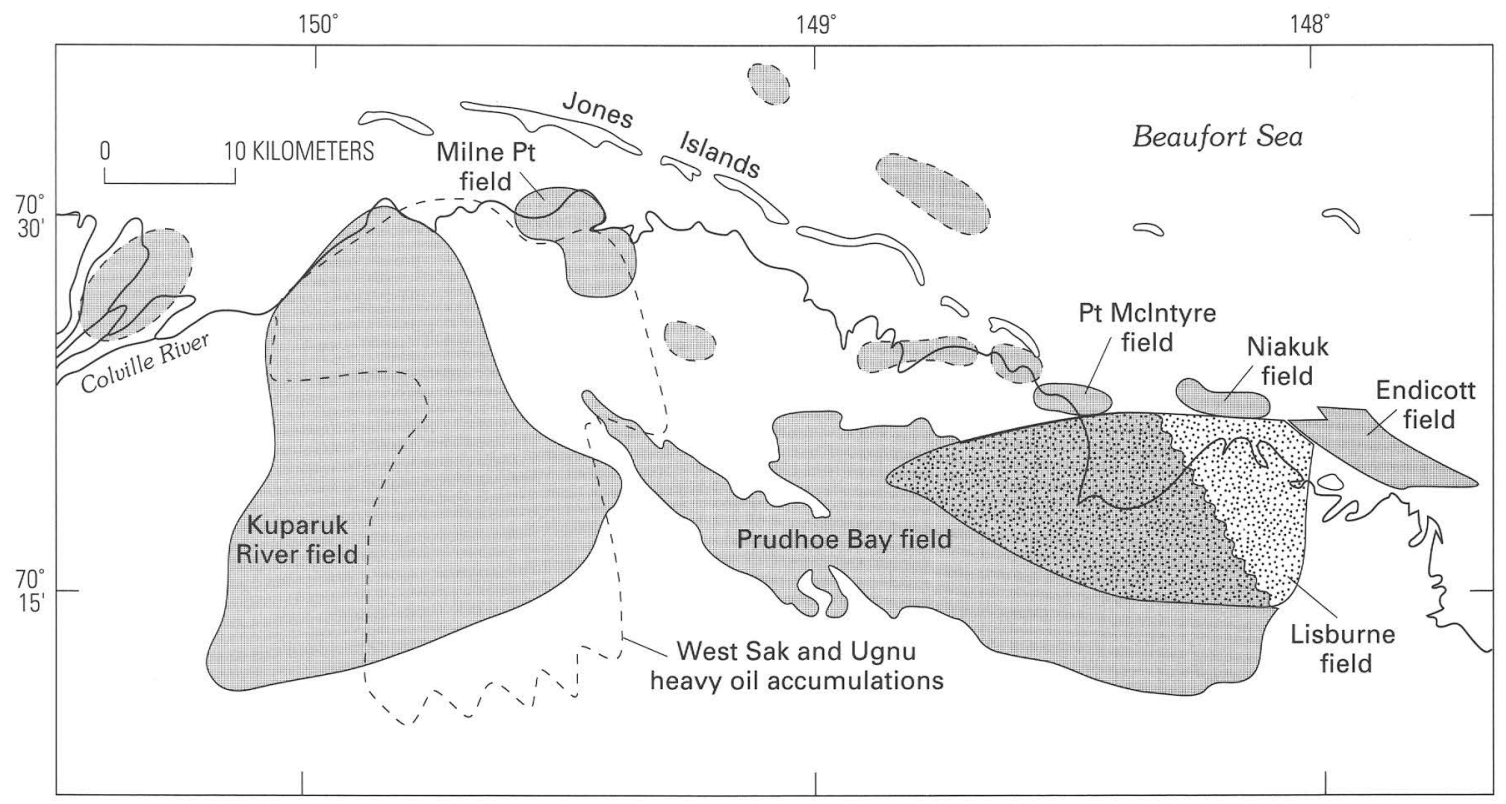

Figure 1 (Bird and others). Oil and gas fields of the greater Prudhoe Bay area, northern Alaska. Patterned dashed outline, nonproductive oil field.

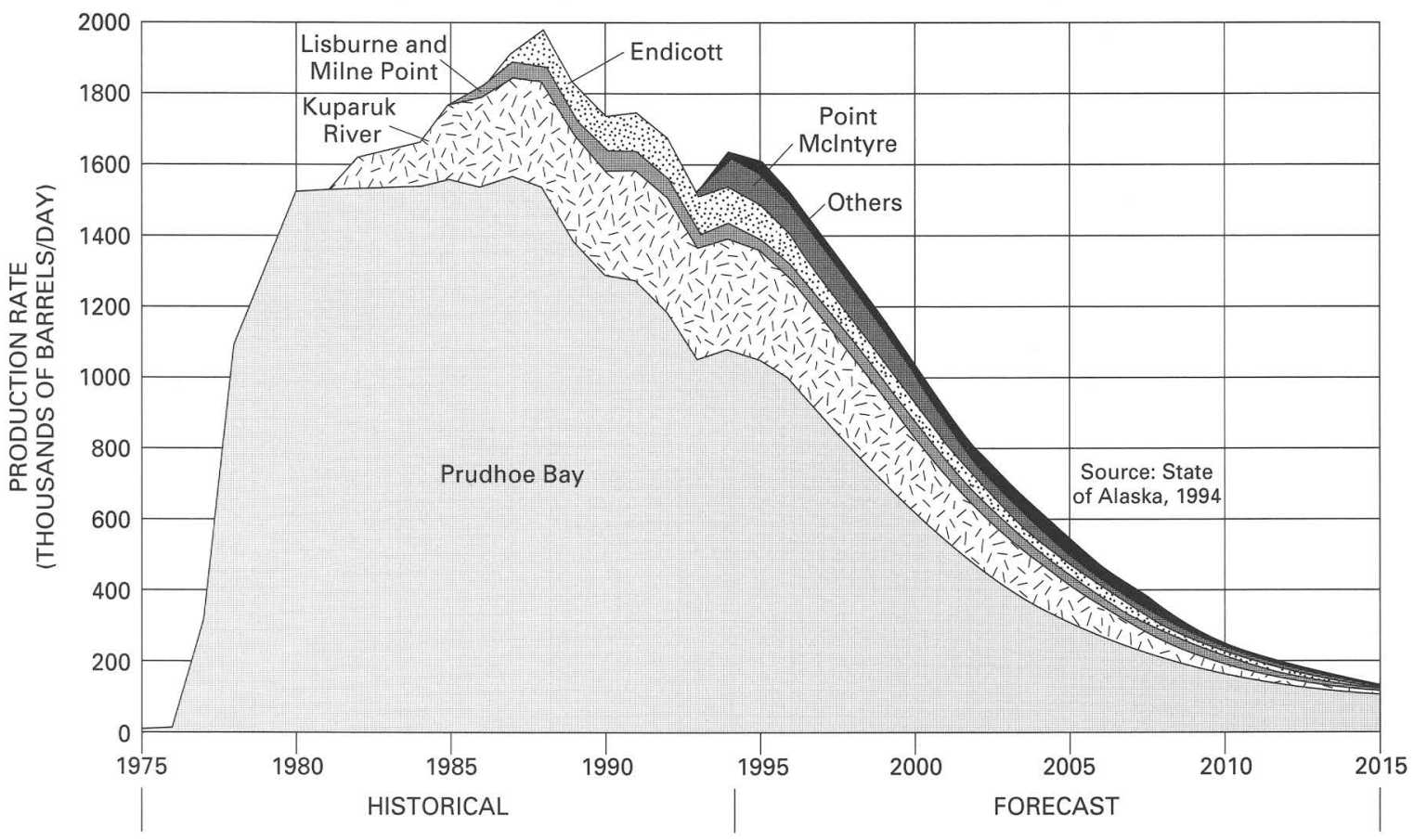

Figure 2 (Bird and others). North Slope oil production. 
Federal and State Coal

\section{Availability/Recoverability Studies in Eastern United States-A New Approach to Coal Resource Assessment}

\author{
M.D. Carter, ${ }^{1}$ T.J. Rohrbacher, ${ }^{2}$ \\ G.A. Weisenfluh, ${ }^{3}$ N. Fedorko, ${ }^{4}$ A.G. Axon, ${ }^{5}$ \\ C.G. Treworgy, ${ }^{6}$ H. Cetin, ${ }^{7}$ D.D. Teeters, ${ }^{2}$ \\ R.I. Geroyan, ${ }^{2}$ R.S. Sites, ${ }^{8}$ and N.K. Gardner ${ }^{1}$
}

(1) U.S. Geological Survey, 956 National Center, Reston, VA 22092; (2) U.S. Bureau of Mines, Intermountain Field Operations Center, P.O. Box 25086, Denver, CO 80225; (3) Kentucky Geological Survey, 228 Mining and Mineral Resources Building, University of Kentucky, Lexington, KY 40506-0107; (4) West Virginia Geological and Economic Survey, Mont Chateau Research Center, P.O. Box 879, Morgantown, WV 26507-0879; (5) Ohio Division of Geological Survey, Fountain Square, Building B, Columbus, $\mathrm{OH} 43224$; (6) Illinois State Geological Survey, 615 East Peabody Drive, Champaign, IL 61820; (7) Indiana Geological Survey, 611 North Walnut Grove, Bloomington, IN 47405; (8) Virginia Division of Mineral Resources, P.O. Box 3667, Charlottesville, VA 22903

\section{Introduction}

The availability of environmentally acceptable and reliable energy sources is an important issue for Federal, State, and local planners. Traditional estimates of coal resources and reserves in the United States do not address the amount of coal made unavailable for production because of environmental, land-use, technological, and geologic constraints. Therefore, a cooperative program between the U.S. Geological Survey (USGS), U.S. Bureau of Mines (USBM), and the geological agencies of the principal coal-bearing States was initiated to (1) identify and delineate the current major restrictions on the availability of coal resources; (2) estimate the amount of remaining coal resources that may be available for development under those constraints; (3) estimate the amount of coal that can be economically extracted and marketed; and (4) identify possible social and economic disruptions that occur within local and regional economies as coal resources are exhausted.

\section{Methodology}

Within major coal-producing regions, 7.5-minute quadrangle study areas are selected on the basis of production history, resource potential, and availability of data. The study areas are chosen to represent the variations in geology, topography, and land-use patterns of their region so that the results can be extrapolated reasonably throughout the entire region.

Land-use/environmental and technologic/geologic restrictions are the two general categories of restraints on coal mining. Land-use/environmental restrictions applicable within the areas studied include the presence of power lines, pipelines, cemeteries, oil and gas wells, roads, railroads, towns, major streams, wetlands, parks, and protected forests. Technologic/geologic restrictions include safety zones around active or abandoned mines, coal beds considered too thin or too deep to mine, mined and minable beds that are too close together, unstable roof or floor rock, and other geologic factors such as washouts, faults, disturbed areas, and impurities in the coal.

After identifying State and Federal coal mining regulations, USGS and State scientists consult with local coalindustry engineers, geologists, and mine operators to ascertain actual local mining practices. Outlines of areas that are underlain by coal, are mined out, and have restrictions to mining are digitized into a public-domain, raster-based geographic information system (GIS) and combined with coal thickness and depth of burial data for manipulation and calculation of restricted and available resources.

All GIS data generated by USGS and State cooperators during the Coal Availability Studies are given to USBM to conduct follow-on studies. The USBM Coal Recoverability Studies utilize GIS and modelling programs to develop and apply recovery and cost factors to the available coal resources. USBM generates detailed estimates of the amount of economically recoverable coal within each study area. An economic impact analysis is made on selected counties to examine the economic structure of mining communities, and the effects of the presence or absence of mining in these communities in the near future. (See Selected References for discussion of methodologies and results of selected studies completed by the participating agencies.)

\section{Results}

Coal availability studies for 17 of the 20 quadrangles selected in the central Appalachian region have been completed by USGS and Geological Surveys of Kentucky, Virginia, and West Virginia. Although results vary considerably among the areas studied, collectively, they indicate that only about one-half of the estimated original 12-billion-ton coal resource in these 17 quadrangles is available for development (fig. 1). Coal mined and lost-in-mining accounts for a 15 percent reduction of the original resource, while landuse/environmental restrictions are 3 percent, and technologic/geologic restrictions, 32 percent.

Coal recoverability studies by the USBM on 11 quadrangles within the central Appalachian region show that 


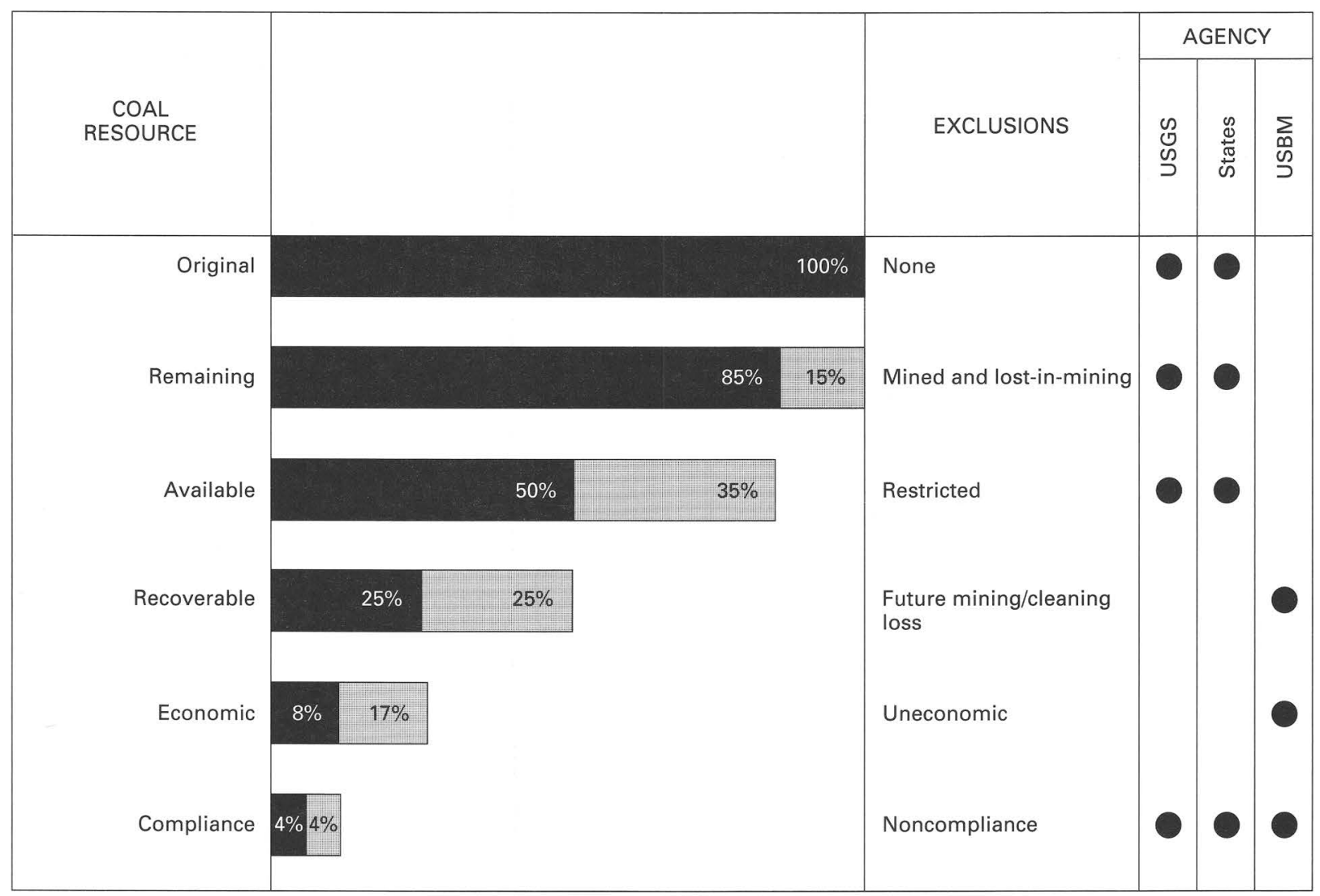

Figure 1 (Carter and others). Results of 17 USGS/State and 11 USBM studies in the central Appalachian region, showing agency areas of responsibility.

approximately 25 percent of the coal resources examined are recoverable and 8 percent of the total resources studied can be economically extracted and marketed. Further, remaining reserves within eight of the quadrangles range from 11 to 51 years of continued mining at present rates of extraction, whereas the three other quadrangles have little or no marketable reserves. An impact analysis on Pike County, Kentucky, the largest coal-producing county in eastern Kentucky, indicates that 21 percent of the employable population is directly or indirectly involved in coal mining and that mining activities account for 46 percent of the county's income.

The sulfur content of the coal is mapped where sufficient data are available; in other cases it is estimated from statistical data. Results from USGS/State and USBM studies in the central Appalachian region indicate that approximately one-half of both the available and the economically recoverable coal in this prime low-sulfur coal region can meet current new-source performance standards of 1.2 pounds of sulfur dioxide per million Btu input.

\section{Conclusions}

The first study areas completed have shown that (1) restrictions to mining have a significant impact on the potential for coal resource development; (2) baseline data from these studies can help determine probable effects of environmental and legislative restrictions not only on coal production, but also on local and regional economies; (3) incorporation of these data early in the policy-formulation process could ensure informed regulations beneficial to both the environment and industry; (4) the interrelated effects of mined-out coal; environmental, industrial, economic, and social considerations; and the technical aspects of the minability and washability of individual coal beds, when all considered, substantially reduce the amount of available and economically recoverable coal to levels far below that previously stated in literature; and (5) being forewarned of potentially affected areas, policy-makers can plan for possible social and economic disruptions that occur as coal resources are exhausted or as mining shifts from high-sulfur to low-sulfur coal production.

The Coal Availability/Recoverability Studies have expanded into the northern Appalachian region and the Illinois basin in cooperation with the geologic agencies of Ohio, Pennsylvania, Illinois, Indiana, and Kentucky. Estimates are that 20 to 30 quadrangle studies should be sufficient to characterize each region. If funding permits, the program 
ultimately will cover 150 quadrangles from the 11 major coal regions of the United States that represent 97 percent of current U.S. coal production. Planned project completion is 2001.

\section{SELECTED REFERENCES}

Axon, A.G., 1994, Available coal resources of the Bethesda 7.5minute quadrangle, Belmont County, Ohio: Ohio Division of Geological Survey, final report to the U.S. Geological Survey for cooperative agreement number 14-008-0001-A0851, 29 p.

Carter, M.D., and Gardner, N.K., 1989, An assessment of coal resources available for development; Central Appalachian region-First year summary: U.S. Geological Survey Open-File Report 89-362, 52 p.

Cetin, Haluk, Conolly, Carol, and Rupp, J.A., 1994, The coal availability study in Indiana-Alfordsville 7.5-minute quadrangle: Indiana Geological Survey Open-File Report 94-8, 53 p.

Eggleston, J.R., Carter, M.D., and Cobb, J.C., 1990, Coal resources available for development-A methodology and pilot study: U.S. Geological Survey Circular 1055, 15 p.

Geroyan, R.I., Teeters, D.D., and Plis, M.N., 1994, Economic impact analysis of the coal mining industry in Pike County, Kentucky: U.S. Bureau of Mines Coal Recoverability Series 1, $21 \mathrm{p}$.

Loud, E.I., Blake, B.M., Jr., and Fedorko, N., 1990, The coal availability study in West Virginia-War 7.5' quadrangle, McDowell County: West Virginia Geological and Economic Survey Open-File Report OF9005, 8 p.

Plis, M.N., Rohrbacher, T.J., and Teeters, D.D., 1993, COALVAL-A prefeasibility software package for evaluating coal properties using Lotus 1-2-3, Release 2.2Documentation and user's guide: U.S. Bureau of Mines Information Circular 9348, 93 p.

Rohrbacher, T.J., Teeters, D.D., Osmonson, L.M., and Plis, M.N., 1994, Coal recoverability and the definition of coal reserves, central Appalachian region, 1993: U.S. Bureau of Mines Recoverability Series 2, $36 \mathrm{p}$.

Rohrbacher, T.J., Teeters, D.D., Sullivan, G.L., and Osmonson, L.M., 1992, Coal reserves of the Matewan quadrangle, Kentucky-A coal recoverability study: U.S. Bureau of Mines Information Circular 9355, $36 \mathrm{p}$.

1993, Coal resource recoverability-A methodology: U.S. Bureau of Mines Information Circular 9368, 48 p.

Sites, R.S., and Hostettler, K.K., 1990, Available coal resources study of Appalachia 7.5-minute quadrangle, Virginia-Kentucky: Virginia Division of Mineral Resources Publication $118,51 \mathrm{p}$.

Treworgy, C.G., Coats, G.K., and Bargh, M.H., 1994, Availability of coal resources for mining in Illinois, Middletown quadrangle, Central Illinois: Illinois State Geological Survey Circular $554,48 \mathrm{p}$.

Weisenfluh, G.A., Andrews, R.E., Hiett, J.K., and Sergeant, R.E., 1993, Available coal resources of the Handshoe 7.5-minute quadrangle, Knott County, Kentucky: Kentucky Geological Survey Information Circular 43, 45 p.

\section{Coal Resource Assessment in the Western United States-Factors for Consideration in the Management of Federal Lands}

\author{
R.D. Hettinger, ${ }^{1}$ L.R.H. Biewick, ${ }^{1}$ Karen Bry- \\ ant, ${ }^{2}$ M.S. Ellis, ${ }^{1}$ D.A. Ferderer, ${ }^{3}$ M.A. Kirsch- \\ baum, ${ }^{1}$ C.L. Molnia, ${ }^{1}$ L.N.R. Roberts, ${ }^{1}$ S.B. \\ Roberts, ${ }^{1}$ G.D. Stricker, ${ }^{1}$ and W.D. Watson ${ }^{2}$ \\ ('U.S. Geological Survey, Denver, CO 80225; \\ ${ }^{2}$ USGS, Reston, VA 22092; ${ }^{3}$ U.S. Bureau of Mines, \\ Denver, CO)
}

The U.S. Geological Survey (USGS) and U.S. Bureau of Mines (USBM) are charged with assessing the coal resources of the United States, an important task considering that approximately 55 percent of the Nation's electric power generation and 23 percent of all domestic energy use are fueled by coal (Energy Information Administration, 1993). About one-third of the Nation's coal resources are on Federal lands in the Western United States (Pantos and Slatick, 1993), principally in Arizona, Colorado, Montana, New Mexico, North Dakota, South Dakota, Utah, and Wyoming. Abundant resources of low-sulfur coal are found within and adjacent to lands administered by the Bureau of Land Management (BLM), National Forest Service, National Park Service, and Bureau of Indian Affairs. The presence of these coal resources has a profound effect on government land-use decisions as regulatory agencies attempt to balance energy development with alternative land-use and environmental concerns.

Averitt (1975) estimated that the Western United States has 2.7 trillion short tons of coal. Such a large figure is misleading, however, because it does not account for technological and societal restrictions to coal production. Many coal beds are either too deep, too thin, or too poor in quality to be economically developed at present. High concentrations of hazardous air pollutant (HAP) elements listed in the 1990 Clean Air Act Amendments may render some coals too expensive for cost-effective development. In addition, mining restrictions provided under the Federal Land Policy and Management Act (FLPMA) place a large percentage of the Nation's surface-minable coal off-limits to mining. Under FLPMA and other legislation, the BLM must prepare landuse plans for areas under Federal jurisdiction, and address factors related to coal exploitation and reclamation within a framework of issues that include preservation of wildlife habitat, alluvial valley floors, historic sites, and scenic wildlands. These plans must also provide buffer zones for roads, lakes, ranches, and towns. With these factors in mind, it is clear that a coal resource assessment of the Western United States must be based on sound geologic principles as well as modern mining, environmental, and economic concepts. 
Information gained through traditional drilling and mapping methods is often not cost effective. In response, the USGS and USBM have developed geologic, economic, and coal availability/recoverability models that afford a costeffective means to provide regulatory agencies with more accurate estimates of our recoverable coal resources. Models developed from areas containing abundant data, such as the Kaiparowits Plateau of Utah and Powder River Basin of Wyoming, can be applied to areas where data are insufficient or lacking. These models predict variations of coal distribution and quality on both local and regional scales.

Regional paleogeographic models developed by the USGS show that coal deposition in the Western United States is related to geologic processes that dominated during the Late Cretaceous (98-66 million years ago) and early Tertiary (66-50 million years ago) periods. For example, Upper Cretaceous coals developed from peats that accumulated in an ever-wet climate along the coastal plains of a seaway that extended from the present Arctic Ocean to the Gulf of Mexico. Later in the Tertiary, the seaway had retreated and peat developed principally in flood plains of river systems in intermontane basins of Colorado, western Montana, and Wyoming, and in shallow basins of eastern Montana and North Dakota. These models are significant because they show that the accumulation and preservation of coal are controlled primarily by ancient climate, sea-level change, and mountain building processes. Knowledge of these processes allows us to better understand the regional distribution of our Nation's western coal resources.

Detailed stratigraphic and geochemical studies enhance our knowledge regarding the effects of geologic processes on the accumulation, distribution, and quality of coal. These aspects of Upper Cretaceous coals are controlled primarily by the orientation and mobility of shorelines that advanced and retreated in response to changes in sea level, climate, and warping of the Earth's crust. For example, results from studies in the Kaiparowits Plateau imply that economically significant deposits of high-quality coal are likely to be associated with shorelines that remained relatively stable for long periods of time. Other examples show that coals associated with rapidly fluctuating shorelines are thin and less likely to have economic value. By contrast, the distribution and quality of Tertiary coals are controlled by the geometry of river systems, which is influenced more by tectonic and climatic forces than by sea level fluctuations. Studies from Tertiary basins show that concentrations of HAP elements are higher in coals that accumulated near Tertiary mountains than in coals that were more removed from the upland areas. The HAP elements are contained in sediment and volcanic debris supplied from the upland areas. Detailed studies such as these provide models that explain the regional and local distribution of coal quality and quantity. These models enable us to refine coal resource estimates in areas where drill hole and outcrop data are insufficient.
To understand the effect of land-use, environmental, technological, and geologic restrictions on the availability and recoverability of coal resources, the USGS and USBM have initiated a "Coal Availability and Recoverability" program in cooperation with other Federal and State arencies. The first western coal availability study has been init ' :ted in the Powder River Basin near an area that contains se"eral of the largest producing coal mines in the Nation. Coal beds in the study area are up to $100 \mathrm{ft}$ thick and can be extracted by surface mining. Local mining practice indicates that features such as roads and ranches would be moved to mine the coal; features such as railroad corridors are presently considered unsuitable for surface mining. Other considerations, such as wildlife sites, may require special environmental protection that could increase the cost and complexity of mining. Results from this western study may prove extremely significant because similar studies from the Appalachian coal region indicate that only 50 percent of the origiral coal resource is available for development (M.D. Carter, written commun., 1994), and less than 10 percent of the original resource can be mined and marketed at a profit (Roh-bacher and others, 1994).

An issue which could grow in importance is the tradeoff between low-cost development of western coal and the environmental benefits achieved through Federal mandates. In many instances, environmental protection can be arhieved only if higher coal operating costs are incurred. Pecause restrictions may increase the cost of coal development, mining patterns may shift to regions that are less affected by regulations. As expected growth in coal utilization could bring pressure for renewed Federal coal leasing, it is impor'ant that a strategy be developed to allow the Federal Government to meet its environmental objectives in a cost-effective manner. Coordinated projects between the USGS, USBM, and other regulatory agencies could identify areas where abundant high-quality coal could be economically developed with the least environmental impact in the future. Results from combined geologic, coal availability, and economic stucies will provide a more realistic basis for national energy policy planning.

\section{REFERENCES}

Averitt, Paul, 1975, Coal resources of the United States, January 1, 1974: U.S. Geological Survey Bulletin 1412, 131 p.

Energy Information Administration, 1993, U.S. coal resirves; an update by heat and sulfur content: DOE/EIA-0529(92), $86 \mathrm{p}$.

Pantos, E.R., and Slatick, E.R., 1993, Federal and Indian coal lands-A growing source of energy and revenue, in Energy Information Administration/Coal Production 1992: D)E/EIA0118(92), $113 \mathrm{p}$.

Rohrbacher, T.J., Teeters, D.D., Osmonson, L.M., and Pl $`_{\odot}$, M.N., 1994, Coal recoverability and the definition of coal reserves-Central Appalachian Region, 1993, Coal Recoverability Series Report No. 2: U.S. Bureau of Mines Open File Report $10-94,36$ p. 


\section{Forest Planning and Oil and Gas Resources- How They Work Together}

\author{
Melody R. Holm and John S. Dersch, \\ U.S. Forest Service, Lakewood, CO
}

\section{Introduction-Forest Service Mission and Minerals Management}

The mission of the U.S. Forest Service is to achieve quality land management under the sustainable multiple-use management concept to meet the diverse needs of people. Minerals, including oil and gas, are some of the resources on National Forests and Grasslands that are necessary to meet the basic needs of people. The development of such resources is necessary to help serve people's needs, maintain a healthy industry, promote economic growth, and maintain national security. At the same time, the Forest Service manages the development of these resources in an ecologically sound manner in order to maintain the diversity, productivity, and sustainability of the ecosystems in which they occur. Decisions about the ecologically sound management of oil and gas resources must be based on reliable scientific information. The U.S. Geological Survey assists the Forest Service in making such decisions by providing such information in a credible and unbiased fashion.

\section{Planning for Oil and Gas Activities}

In order to comply with specific laws and regulations, the Forest Service must conduct environmental analyses of National Forest Service (NFS) lands before they are leased for oil and gas exploration and development. Analysis of effects from leasing can be done in two ways: (1) in an environmental impact statement as an amendment to an existing forest plan, or (2) in a forest plan revision. In either case, the regulations require a projection of the type and amount of post-leasing activity that might be expected if specified lands are leased. Such projections provide the basis for analyzing effects from surface-disturbing activities that might result if those wells were drilled. The analysis of effects, in turn, provides the basis for decisions about what lands may be leased and what kinds of stipulations the leases may have.

Knowledge of regional and local geology helps in projecting the number and type of possible future exploratory and development wells in a National Forest or Grassland. Geology determines the potential for oil and gas resources to exist in the area. Past and present exploration and production activity also helps determine what activity might occur in the future. USGS oil and gas assessment information includes concise, unbiased maps, discussions of geology, play ${ }^{1}$

\footnotetext{
${ }^{1}$ Play: a set of discovered or undiscovered oil and gas accumulations or prospects that are geologically related.
}

descriptions, resource volume estimates, and references. Such scientific resources are valuable tools in determining an area's potential for having oil and gas resorrces and projecting future exploration and development act ivity.

\section{Oil and Gas Resources in the Rio Grande National Forest}

Specialists on the Rio Grande Nationa' Forest in southem Colorado are analyzing effects from pro: $:$ cted oil and gas activities in order to develop management direction for those activities in its Forest Plan Revision. The report, "Oil and Gas Resources on the Rio Grande National Forest" (Holm and Dersch, 1994) was developed in support of the Plan Revision. It summarizes the geology and potential for oil and gas resources on the Rio Grande National Forest (RGNF). The report also projects possible future exploration and development activity. USGS assessment information provided much of the basis for determining the oil and gas potential and projected activity on the RGNF. The USGS defined and assessed one play which is almost entirely on the RGNF (fig. 1). The play map, summary of $\mathfrak{g}$. ology, and play description provided valuable information for determining that much of the RGNF has a high potential for the existence of oil and gas resources. However, limited production to 1994 and relatively low resource estimates for the play indicate that future activity levels will most lik-9ly be no higher than those of the past.

\section{Oil and Gas Resources in Thunder Basin National Grasslands}

USGS oil and gas plays are not exactly coincident with the boundaries of a National Forest or Grassland. However, understanding the nature of a play and lnowing its geographic boundaries in relation to a forest or grassland are still valuable tools in planning for management of oil and gas resources. In the case of the Thunder Basir National Grasslands (TBNG) in northeastern Wyoming, nine plays are significant to the TBNG (fig. 2). More than 90 percent of the TBNG lies entirely within the boundaries of two plays, and varying portions of the TBNG lie within the boundaries of the remaining seven. Knowledge of geolo?ical characteristics, degree of development, and resource potential of each play and play distribution facilitated more reliable projection of wells in the leasing analysis.

\section{Conclusion}

In order to assess effects from leasing, a planner needs to have an idea of how many and what type of wells might be drilled in a particular area. Knowing the type and level of anticipated activity and its possible effects on other resources helps in determining which lands may be appropriate for leasing and what kinds of stipulations might be 


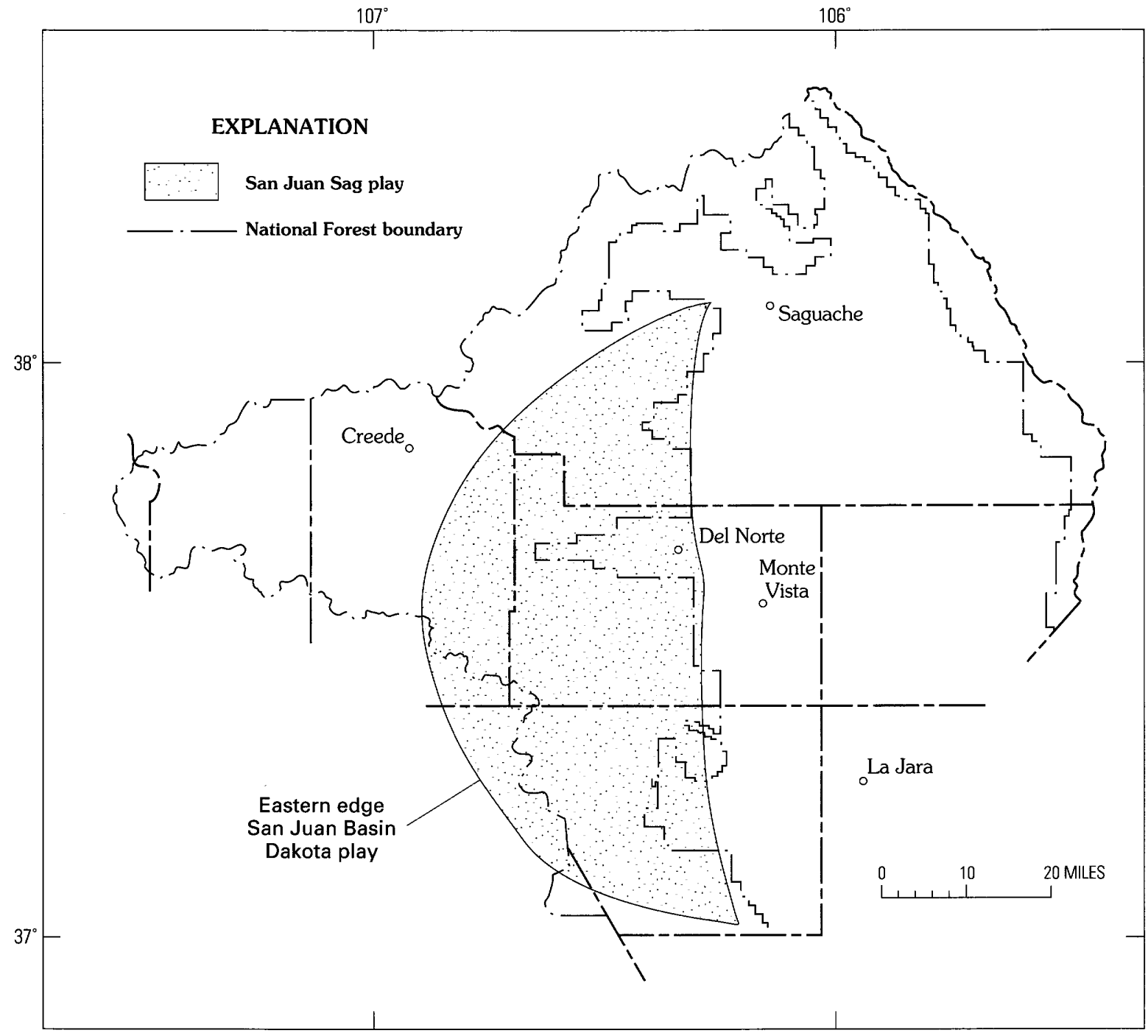

Figure 1 (Holm and Dersch). USGS oil and gas plays on the Rio Grande National Forest, southern Colorado.

necessary for protection of other resources on those lands. USGS assessment information is an important component of the analysis process that ultimately results in decisions about leasing NFS lands for oil and gas exploration and development. Such decisions lead to environmentally sound oil and gas resource development, a constant supply of oil and gas to serve people's needs, the support of a healthy domestic energy industry, and the maintenance of economic growth and national security.

\section{REFERENCES}

Holm, M.R., and Dersch, J.S., 1994, Oil and gas resources in the Rio Grande National Forest: U.S. Forest Service unpublished report.

Holm, M.R., Powers, R.B., Dolton, G.L., Law, B.E., Fox, J.E., and Dersch, J.S., 1993, Undiscovered oil and gas resources and leasing status of forest lands in Wyoming: Wyoming Geological Association 50th Annual Field Conference Gui Jebook, p. 375-385. 


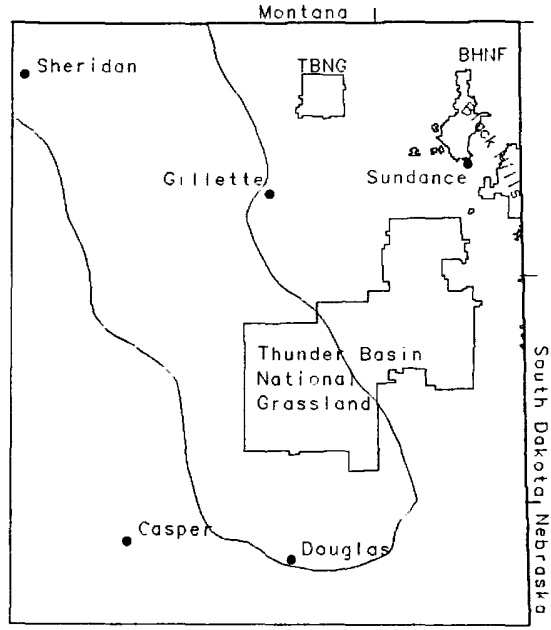

Mesaverde-Lewis Play

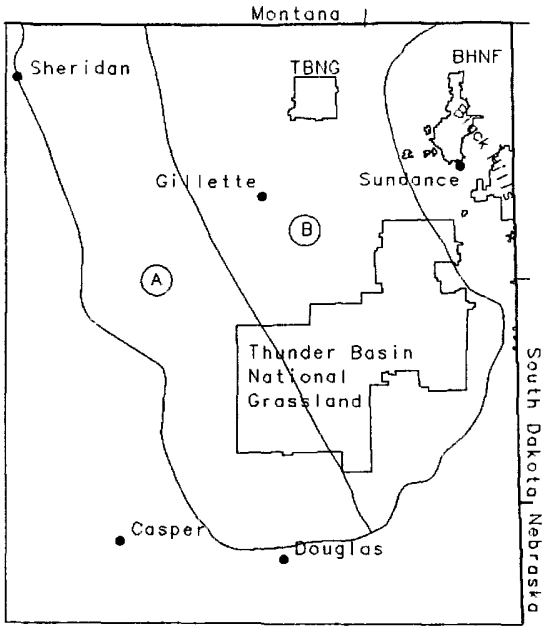

Deep Muddy Sandstone

(A) and Shallow Muddy

Explored (B) Plays

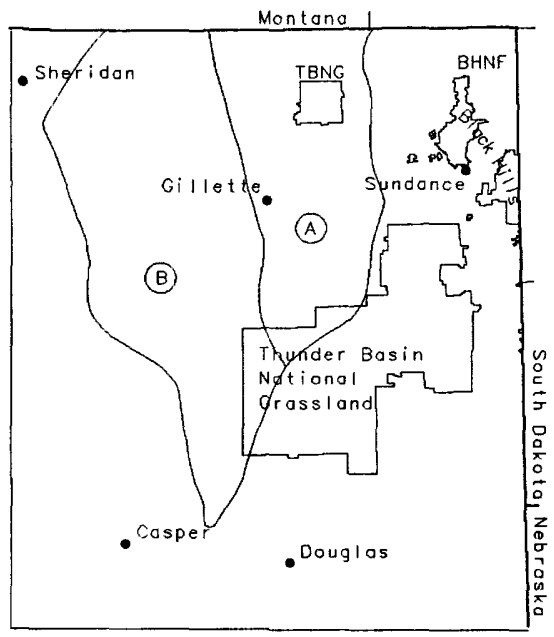

Minnelusa Explored (A)

and Minnelusa Unexplored

(B) Plays

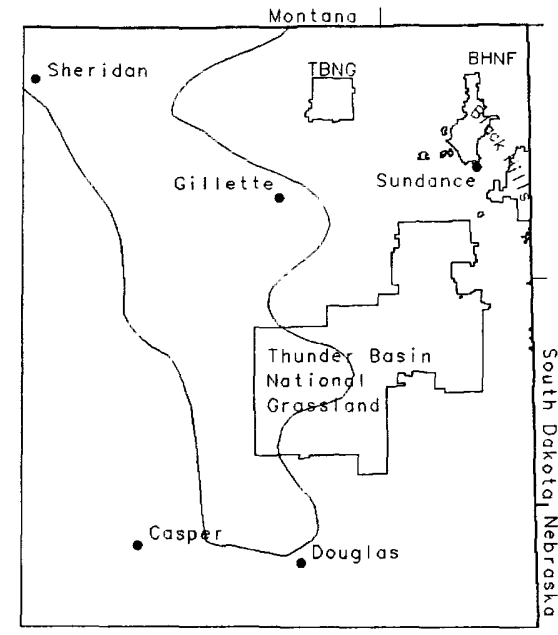

Sussex-Shannon PI ay

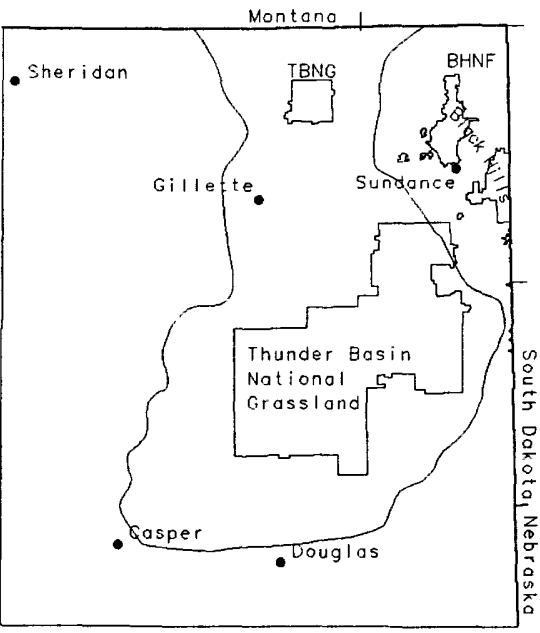

Dakota Sandstone Play

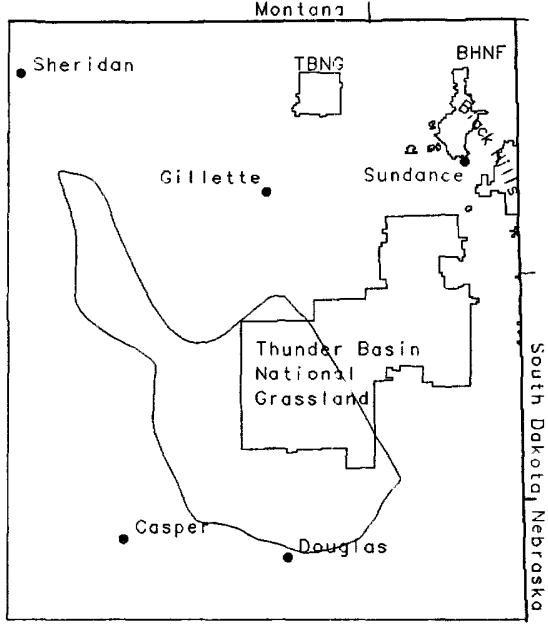

Deep Frontier Flay

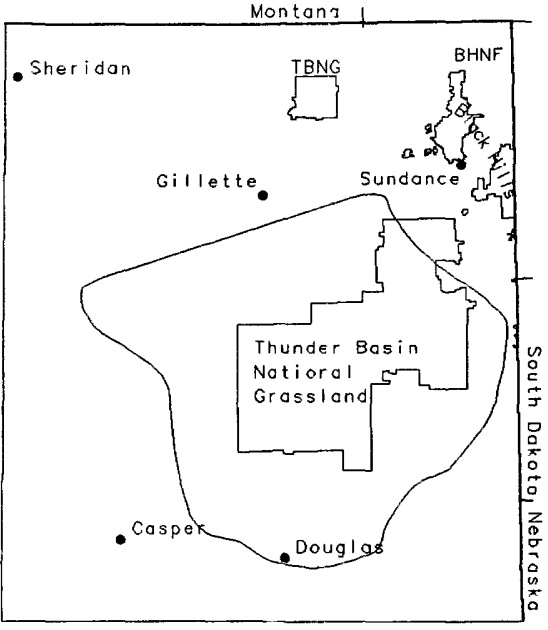

Leo Sandstone Play

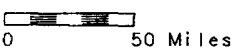

Figure 2 (Holm and Dersch). Maps of northeast Wyoming showing Thunder Basin National Grassland, Black Hil $~$ National Forest, and USGS oil and gas plays in the Powder River Pasin province. Additional Powder River Basin province plays not significant to the grassland are not shown (Holm and others, 1993). 


\section{Interagency Cooperation for Mineral Leasing and Operations on Federal Lands}

\author{
Gary W. Horton, Office of the Assistant \\ Director, Resource Use and Protection, \\ Bureau of Land Management, 1849 C Street \\ N.W., Washington, D.C. 20240
}

The Bureau of Land Management works with a wide range of other Federal agencies to fulfill its mission of leasing and regulation of operations of energy and minerals on Federal and Indian lands. Two types of cooperation are required, regulatory and scientific.

Most mineral operators are well aware of the regulatory requirements of Fish and Wildlife Service, Office of Surface Mining, Forest Service, and Bureau of Indian Affairs, and other surface managing agencies with regards to Federal and Indian leases. However, the extent of cooperation required is rarely understood outside the government. Usually, there are broad, less obvious areas of interagency coordination that are of increasing importance.

As an example, take the cooperation necessary to fulfill both the broad mission of the Fish and Wildlife Service and of the Bureau of Land Management. Traditionally, the Fish and Wildlife Service interface with the BLM was restricted to providing terms for leasing and operations of mineral leases on refuge lands. With the passage of the Endangered Species Act, the areas of mutual interest were expanded. We now must comply with the specific land uses and constraints of all threatened and endangered species recovery plans. Areas designated in recovery plans are large. Six million acres in California, Nevada, Arizona, and Utah are involved in the recovery plan for the Mojave Desert Tortoise. All lands of less than 3,000 feet elevation are considered habitat for certain plants in the San Joaquin Valley of California. A major part of the Colorado River system is covered by a recovery plan for the squawfish. Within these areas, if mineral operations are not forbidden, leasing and subsequent operations will still often require on-the-ground biological assessment to determine the presence or absence of the species, in order to get a favorable ruling of "no jeopardy" from the authorized officer of the Fish and Wildlife Service.

Even with existing operations, the effect of the Fish and Wildlife Service is profound. If an area is determined to have a threatened or endangered species, the existing mineral operations may be ruled to put the continued existence of that species at risk. In an early preliminary examination, it was suspected that polycyclic aromatic hydrocarbons from operations in the San Juan gas field in New Mexico and Colorado may affect the squawfish and razorback sucker populations of the San Juan River. The BLM has committed to a multi-year program to monitor runoff from the gas field. The project is data intensive and requires a high degree of biological expertise. The newly formed National Biological
Survey has committed itself to a major role in the investigation.

The National Biological Survey has also committed to work on bird mortality at the playa lakes in southeastern New Mexico. The birds are covered by the North American Migratory Bird Treaty, administered by the Fish and Wildlife Service. The playa lakes have received waste waters from potash mines and oil and gas operations.

The pattern of research agencies cooperating $w^{\text {th }}$ the BLM to provide scientific data and conclusions is ernanding. The cases just cited involving the National Biological Survey are as new as the 1-year-old agency. Deeprer and older ties are with the U.S. Geological Survey and Bureau of Mines. The average working geologist for the BLM has traditionally relied on the geologic and topographic maps of the USGS to begin his or her field work. The increasingly rapid expansion of geologic data, and the need to reflect all $c^{\text {rnects }}$ of mineral development, past and present, in our planning work, have expanded our needs beyond the standar 1 map series and publications available to the general public.

The Bureau of Land Management is required to conduct resource management planning for all public lands on a systematic basis to determine resource use over the life $c$ each plan. The USGS and the Bureau of Mines have provid ad and continue to supply Resource Assessment reports and data on minerals to support scheduled Resource Management Plans. A less formal approach is taken for oil and gas assess nents. BLM procedures specify that any geologist or engineer working on oil and gas for a Resource Management P' an get the basic resource data from the specialist on that are $r$ in the USGS. This approach allows the BLM to handle the temporary workload of preparing the geologic and mineral data without large reallocation of personnel between districts. It also gives us immediate access to recognized specialists, not easily available in our district areas. By contrast, bnth the USGS and the Bureau of Mines find that the cooprative work is a normal extension of their basic research cherters.

Another area of cooperation is the ongoing inven 'ory of abandoned mines on Federal land. Thousands of mining claims have been worked over the last hundred years. Most of the better ore deposits have been patented and are no longer public lands. However, thousands of either small or marginal deposits were worked only during the great mining booms. These were abandoned as the ore ran out or the prices tumbled. The eventual remediation of the land will fall to the Federal Government.

This is truly a multi-agency project. Basic data on mine location are coming from the USGS and Bureau of Mines. Satellite imagery analysis is being expanded to work with the Department of Defense equipment and imagery. Field verification is done by BLM employees. Research on minewater remediation is done by the BLM and Bureau of Mines in cooperation with the Atlanta Cluster of Historically Black Colleges. It is expected that any revision of the Miniro Law 
will increase pressure to both expand the program and begin clean-up.

At BLM we expect agency cooperation to increase as the boundaries between agencies become more transparent. The Executive Order of April 11, 1994, "Coordinating Geographic Data Acquisition and Access: The National Spatial Data Infrastructure," required the government to establish a National Geospatial Clearinghouse by October 11, 1994; by January 11, 1995, to collect all new data under Federal Geographic Data Committee standards and enter them into the Clearinghouse electronically accessible to the network; by April 11, 1995, to adopt a schedule for the entry of all other data, adopt a plan making geospatial data available to the public, and adopt internal procedures to ensure that every agency accesses the Clearinghouse to determine if their data have already been collected, or whether cooperative efforts to obtain the data in question are available.

Increasingly, it is required that all land-managing agencies do their resource use management together. Within several years, what we now see as special projects, governed by agreements, will become simply standard operating modes. The fundamental energy and mineral resource data will become increasingly important to all land-management agencies.

\section{Oil in California-Quality, Availability, and Environmental Concerns}

\author{
Caroline M. Isaacs, Leigh C. Price, \\ Larry A. Beyer, Kenneth J. Bird, \\ James R. Herring, Margaret A. Keller, \\ Paul G. Lillis, Leslie B. Magoon, \\ David Z. Piper, Richard G. Stanley, and \\ Marilyn E. Tennyson, U.S. Geological Survey, \\ Menlo Park, CA 94025, and Denver, CO 80225 \\ (J.R. Herring; L.C. Price)
}

California is the fourth largest oil- and gas-producing State in the United States, representing about 14 percent of the Nation's current oil production, 21 percent of proved oil reserves, and more than 40 percent of additional indicated reserves (Conservation Committee of California Oil and Gas Producers, 1992). Cumulative production was 23.5 BBO (billion barrels of oil) and 33.7 TCFG (trillion cubic feet of gas), for a combined total of $29.1 \mathrm{BBOE}$ (billion barrels of oil equivalent) through 1992 (California Division of Oil, Gas, and Geothermal Resources, 1993). Proved reserves were 4.3 BBO and 3.9 TCFG, for a combined total of 5.0 BBOE at yearend 1992 (California Division of Oil, Gas, and Geothermal Resources, 1993).

California is a relatively well developed oil and gas region, having commercially produced petroleum since 1876
(California Division of Oil, Gas, and Geotl srmal Resources, 1993). During the late 1970 's and early 1980 's, oil and gas exploration and development were very active in California, particularly in the offshore Santa Maria basin and Santa Barbara Channel. Numerous oil fields were di`covered offshore during this period, but few have yet been developed due to economics and environmental and regulatory concerns. As of 1989 , economically recoverable resources in undiscovered fields were estimated by the USG 5 for the onshore region and adjacent State waters at 2-11 BBOE (mean probability, $5 \mathrm{BBOE}$ ), and by the Minerals Maragement Service for the Federal offshore at 0-6 BBOE (maan probability, 3 BBOE) (Mast and others, 1989).

California's oil and gas production history has been much influenced by the abundance of hervy oil. The State has more than 50 percent (42 BBO) of the Nation's in-place heavy oil resources and, for prices up to $\$ 40 / \mathrm{bbl}$, nearly 95 percent (11 BBO) of the Nation's recoverable potential from heavy oil resources (Dowd and others, 19 9 ). Because it is highly viscous, heavy oil is difficult to re over by conventional production methods, and average recovery efficiencies from primary production and waterflooding are comparatively low, generally amounting to only 5-20 percent of oil in-place (Dowd and others, 1988). In order to access these resources, California's oil and gas industry has pioneered enhanced recovery techniqres, which now account for more than 60 percent of the S'ate's annual production (California Division of Oil, Gas, and Geothermal Resources, 1993).

Based on trends in recent decades, mo st new reserves in California in the near-term will probably' derive from the growth of existing oil fields due to long-term field development and application of improved production technologies. During the 1980's, such field growth accounted for more than 99 percent of new proved reserves ir onshore California, mainly in large fields discovered befo-e the 1930's (fig. 1). The total potential resource from field growth in California has proved difficult to quantify reliahly and is highly price-dependent (Attanasi and Root, 1993), but reserve additions during the 1980's totaled $5 \mathrm{BBOE}$, ard potential future additions likely exceed $10 \mathrm{BBOE}$.

Recent USGS research suggests another possible source of oil resources in California. This research addresses the fundamental issue of the efficiency of rrimary petroleum migration and has focused on the Bakken Formation in the Williston basin of North Dakota and southern Canada. Results show that oil generated by the Bakken (the richest petroleum source-rock in the area) has not migrated to the known oil fields and probably remains locked in the source rocks themselves (Price and LeFever, 1992). If primary petroleum migration is much less efficiert than previously assumed, as indicated by this USGS res arch, significant resources may remain in California's source rocks and might be accessible by new exploration, drilling, completion, and production techniques (Price and LeFever, 1992). 


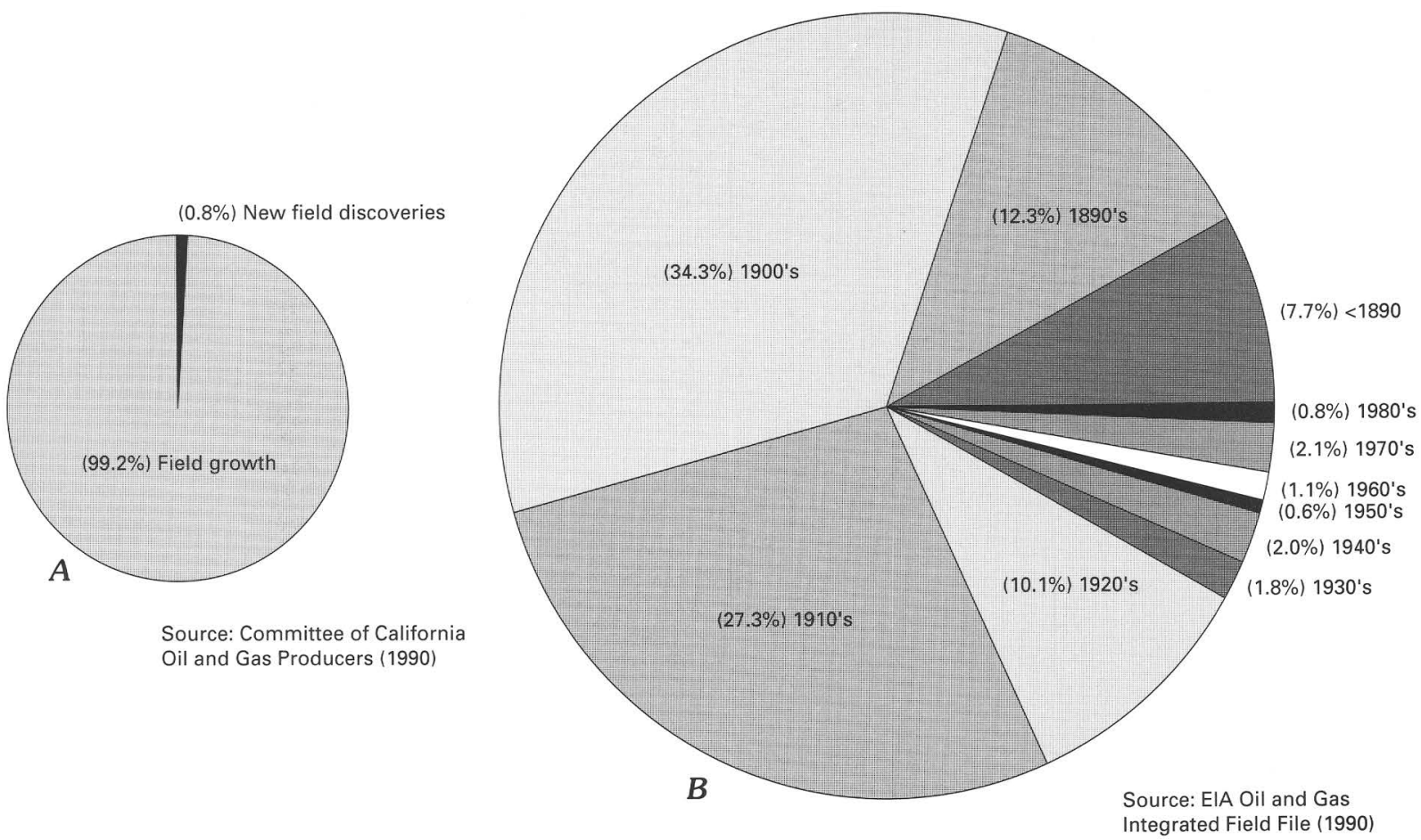

Figure 1 (Isaacs and others). Field growth in California. A, Proved oil and gas reserves added in onshore California oil fields during 1980-1990. Note that less than 1 percent of additions came from new field discoveries; the remainder derived from field growth - new pools, extensions, and revisions of reserves in previously discovered fields. $B$, Proved oil and gas reserves added in onshore California oil fields during 1980-1990, grouped by decade of the oil field's discovery. Although field growth is usually attributed mainly to young fields, most added proved reserves ( $>90$ percent) in California derived from fields discovered before the 1930's.

Environmental concerns in California include the threat of oil spills (particularly in offshore areas), natural oil seeps, production hazards in urban areas, and contamination of soil, ground water, and air from production and refining processes. Natural oil seeps, such as the famous Rancho La Brea Tar Pits of the Los Angeles area, are widespread in California. In order to better understand the relationship of natural oil and gas seepage to environmental concerns and oil resources, the USGS has recently undertaken a project to document and characterize these seeps in collaboration with the California Department of Conservation, Department of Fish and Game, and Department of Parks and Recreation. A new technological development in the last few years that may help to alleviate environmental concerns from oil spills is extended-reach drilling. Because this technology allows oil fields to be efficiently produced from a distance of more than 3 miles $(5 \mathrm{~km})$, many offshore platforms could be eliminated in the future, especially within the coastal State waters.

Another major environmental concern in California is contamination of soil and water supplies from selenium and other hazardous trace elements that derive from the natural weathering of energy-source rocks. This problem, which is widespread in the arid and semi-arid West, is of special concern in the major agricultural areas of California (Herring, 1991). USGS research on this issue has focused on the San Joaquin Valley, in cooperation with the U.S. Bureau of Reclamation, U.S. Fish and Wildlife Service, California Department of Fish and Game, and California Department of Water Resources (Presser and others, 1990).

\section{REFERENCES}

Attanasi, E.D., and Root, D.H., 1993, The enigma of oil and gas field growth: American Association of Petroleum Geologists Bulletin, v. 78, p. 321-332.

California Division of Oil, Gas, and Geothermal Resources, 1993, 78th Annual report of the State Oil and Gas Supervisor-1992: California Department of Conservation, Division of Oil, Gas, and Geothermal Resources, Publication PR06, 159 p.

Conservation Committee of California Oil and Gas Producers, 1992, Annual review of California oil and gas production 1991: Los Angeles, Calif., Conservation Committee of California Oil and Gas Producers.

Dowd, W.T., Kuuskraa, V.A., and Godec, M.L., 1988, A technical and economic assessment of domestic heavy oil-Final report: Department of Energy Report DOE/BC/10840-1, 130 p. + 4 appendices.

Herring, J.R., 1991, Selenium geochemistry-A conspectus, in Severson, R.C., Fisher, S.E., Jr., and Gough, L.P., eds., 
Proceedings of the 1990 Billings Land Reclamation Symposium on Selenium in Arid and Semiarid Environments, Western United States: U.S. Geological Survey Circular 1064, p. $5-24$.

Mast, R.F., Dolton, G.L., Crovelli, R.A., Root, D.H., Attanasi, E.D., Martin, P.E., Cooke, L.W., Carpenter, G.B., Pecora, W.C., and Rose, M.B., 1989, Estimates of undiscovered conventional oil and gas resources in the United States-A part of the Nation's energy endowment: U.S. Geological Survey and Minerals Management Service, 44 p.

Presser, T.S., Swain, W.C., Tidball, R.R., and Severson, R.C., 1990, Geologic sources, mobilization, and transport of selenium from the California Coast Ranges to the western San Joaquin Valley-A reconnaissance study: U.S. Geological Survey WaterResources Investigations Report 90-4070, 66 p.

Price, L.C., and LeFever, J.A., 1992, Does Bakken Horizontal Drilling imply a huge oil-resource base in fractured shales?, in Schmoker, J.W., Coalson, E.B., and Brown, C.A., eds., Geological studies relevant to horizontal drilling-Examples from western North America: Rocky Mountain Association of Geologists, p. 199-214.

\section{Energy Studies on Native American Lands Funded by U.S. Department of Energy- Gas Resources and Sandstone Reservoirs of the Wind River Reservation, Wyoming}

\author{
Ronald C. Johnson, Romeo M. Flores, and \\ William R. Keefer, U.S. Geological Survey, \\ Denver, CO 80225
}

The Wind River Reservation of the Shoshone and Arapahoe Tribes in central Wyoming contains large reserves of natural gas in early Tertiary age (67 to 37 million years) sandstone reservoirs. These sandstone reservoirs are gas productive at two fields in the Reservation-the Pavillion field and the Muddy Ridge field (fig. 1). As of July 1993, the Pavillion field had produced 66.5 BCFG (billion cubic feet of gas) from the Paleocene (67 to 55 million year old) Fort Union Formation and 72.4 BCFG from the lower Eocene (55 to 50 million year old) Indian Meadows or Wind River Formation; the nearby Muddy Ridge field had produced 17.3 BCFG from the Fort Union Formation. Gas is produced from several lenticular, conglomeratic sandstones in the Paleocene Fort Union Formation, whereas lower Eocene production is from a single, relatively continuous unit of conglomeratic sandstone near the base of the lower Eocene section. These productive sandstones are exposed on the surface in the Reservation in three areas: (1) the Twin Buttes area on the south flank of the Owl Creek Mountains; (2) near Shotgun Butte; and (3) on the east end of Little Dome (fig. 1). These areas were studied in detail to better characterize the geometry and distribution of these reservoirs in the subsurface. This information is important for understanding production characteristics of gas wells in the Pavillion and Muddy Ridge fields area and will help predict where economic amounts of natural gas may be found in lower Tertiary reservoirs in presently nonproductive areas of the Reservation. Oil and gas production from existing oil and gas fields in the Reservation has been declining, and this decline is a major concern of the Shoshone and Arapahoe Tribes.

The Fort Union Formation is divided into three members, in ascending order, the lower unnamed member, the Waltman Shale Member, and the Shotgun Member (Keefer, 1961). The lower member varies from about $1,000 \mathrm{ft}$ to more than $3,500 \mathrm{ft}$ thick in the Reservation and consists of sandstone and conglomeratic sandstone and gray mudstones. The sandstones produce gas at the Pavillion and Muddy Ridge fields. Detailed outcrop studies indicate that sandstone units are as much as $60 \mathrm{ft}$ thick and a few hundred feet wide, and that they were deposited by braided, meandering, and anastomosing stream systems (Flores and Keighin, 1993). The Waltman Shale Member does not crop out in the Reservation but occurs in the subsurface in the northeast corner of the Reservation. It consists largely of organic-rich gray to black shale deposited in Paleocene Lake Waltman, which covered much of the central part of the basin.

The Shotgun Member is thought to be largely time equivalent to the Waltman Shale Member and varies from about $800 \mathrm{ft}$ to as much as $3,500 \mathrm{ft}$ thick in the Reservation. Outcrop studies near Shotgun Butte and on the east end of Little Dome indicate that the Shotgun Member consists of stream-deposited sandstones interbedded with mudstone, carbonaceous shale, and thin coal beds. Sandstones in the lower part of the member are in general about $15 \mathrm{ft}$ thick and $300 \mathrm{ft}$ wide and are probably too small to be economic gas reservoirs in the subsurface. Sandstones in the upper part of the Shotgun, in contrast, are as much as $65 \mathrm{ft}$ thick and 4,000 $\mathrm{ft}$ wide. These sandstones form productive reservoirs in the Pavillion and Muddy Ridge fields.

In the Twin Buttes area the Shotgun Member is about $1,250 \mathrm{ft}$ thick (Keefer and Troyer, 1964) and consists mainly of gray to black mudstone deposited in a poorly drained floodplain. This muddy facies extends along a narrow belt just south of the Owl Creek Mountains (Johnson and others, 1994) and was deposited as the nearby Owl Creek Mountains were actively rising. Sandstones are sparse and generally less than $15 \mathrm{ft}$ thick. In addition, many of these sandstones contain shale breaks that would act as barriers to

Figure 1 (Johnson and others) (facing page). Structure contour map (contours in feet) on the base of the Upper Cretaceous Mesaverde Formation, Wind River Reservation, Wyoming, showing major anticlines and synclines. Areas where the Upper Cretaceous Mesaverde and Meeteetse Formations crop out are shown by fine stipple; areas where the formations are buried by younger rocks are shown by coarse stipple. Locations of study areas 1-3 (in text) are shown. 

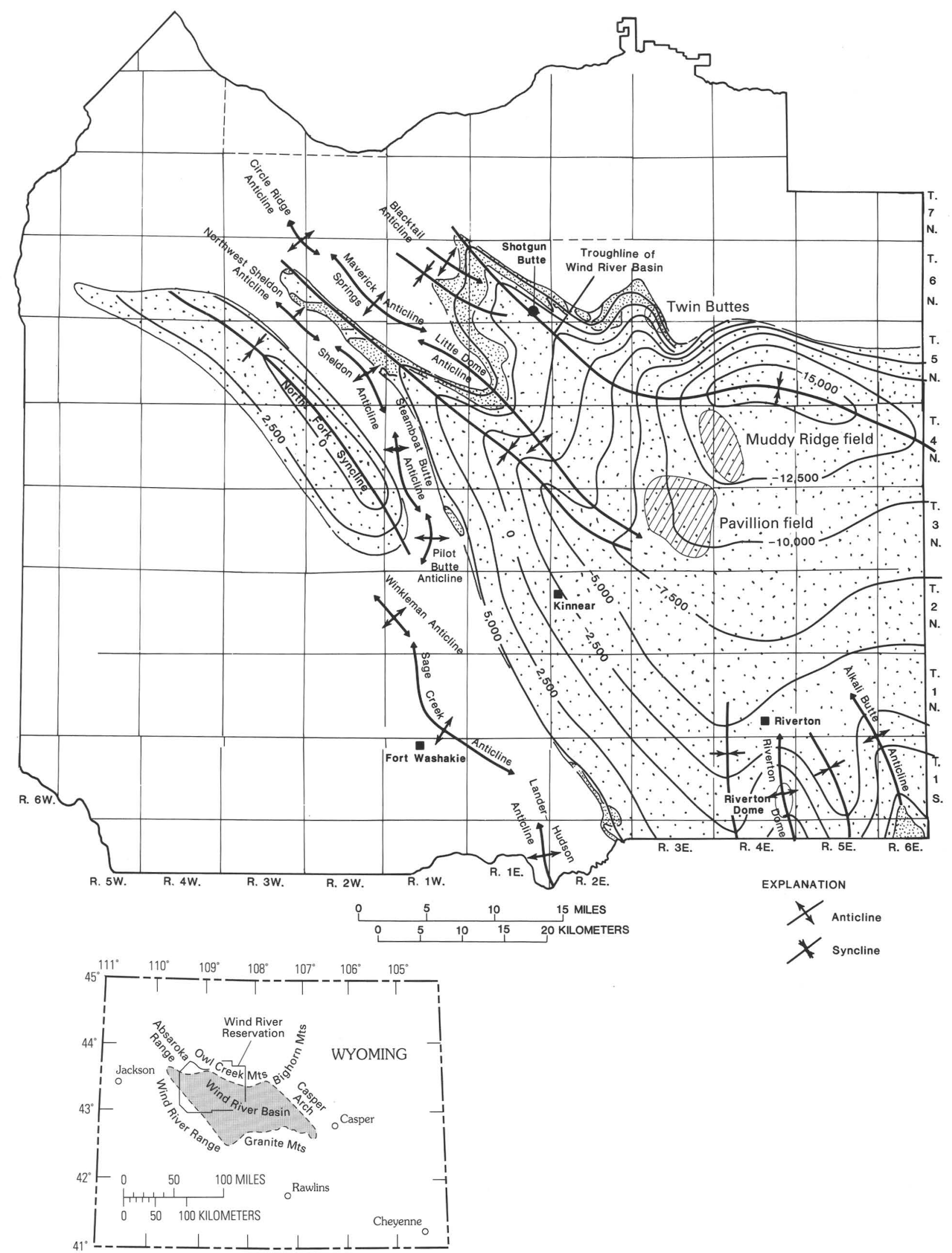
gas flow in the subsurface. Thus these sandstones are not potential gas reservoirs. Carbonaceous shale and thin coal beds occur in the Shotgun Member here, indicating that peat swamps and mires were common. Much of the mudstone found in the Shotgun Member here appears to have eroded from older Cretaceous shales that were exposed in the Owl Creek Mountains when the Shotgun was being deposited. The sparseness of channel sandstones suggests that this unit was deposited mainly by sheetflow.

Lower Eocene strata in the Wind River Reservation comprise two units: a basal Indian Meadows Formation and the overlying Wind River Formation. In the Reservation, outcrops of the Indian Meadows Formation are discontinuous, and in many areas, the Wind River directly overlies older units. The Indian Meadows overlies older units with angular discordance in the Twin Buttes area, indicating uplift prior to deposition. In contrast, at Shotgun Butte and at Little Dome, no uplift occurred prior to deposition of the Indian Meadows Formation. Maximum thickness of the Indian Meadows Formation measured in outcrop was $675 \mathrm{ft}$ at Shotgun Butte. The Indian Meadows contains conglomeratic sandstones as much as $58 \mathrm{ft}$ thick and several thousand feet wide, containing boulder clasts derived from Paleozoic rocks. Operators in the Pavillion and Muddy Ridge fields may have included these sandstones with the productive sandstones found in the upper part of the underlying Shotgun Member of the Fort Union Formation; hence some of the production listed as from the Shotgun Member may actually be from the Indian Meadows Formation.

The Wind River Formation overlies the Indian Meadows with angular discordance and contains boulders of granite as well as boulders of Paleozoic rock. A laterally persistent unit of boulder conglomerate and muddy boulder conglomerate as much as $220 \mathrm{ft}$ thick occurs at the base of the Wind River Formation in the Twin Buttes area and at the east end of Little Dome. This conglomerate appears to be the highly productive unit in the Wind River Formation at Pavillion field. The bouldery parts were deposited by streams which flowed across alluvial fans whereas the muddy bouldery parts represent debris flows that were deposited on the alluvial fans during occasional wet periods. Above the basal conglomerate, the Wind River consists mainly of maroon and gray mudstone and sandstones which are much thinner and less persistent laterally than the basal conglomerate. These sandstones are not known to be gas productive anywhere in the Reservation. Studying these sandstone reservoirs in outcrop has greatly improved our knowledge of these productive units and may lead to better strategies for exploring for gas resources in the future in the Wind River Reservation.

\section{REFERENCES}

Flores, R.M., and Keighin, C.W., 1993, Reservoir anisotropy and facies stratigraphic framework in the Paleocene Fort Union
Formation, western Wind River Basin, Wyoming, in Keefer, W.R., Metzger, W.J., and Godwin, L.H., eds., Oil and gas and other resources of the Wind River Basin, Wyoming: Wyoming Geological Association Special Symposium, p. 121-141.

Keefer, W.R., 1961, Waltman Shale and Shotgun Members of the Fort Union Formation, Wyoming: American Association of Petroleum Geologists Bulletin, v. 45, no. 8, p. 1310-1323.

Keefer, W.R., and Troyer, M.L., 1964, Geology of the Shotgun Butte area, Fremont County, Wyoming: U.S. Geological Survey Bulletin 1157, 123 p.

Johnson, R.C., Flores, R.M., Szmajter, R.J., and Finn, T.M., 1994, A preliminary study of coal-forming environments during deposition of the Paleocene Fort Union Formation, Wind River Basin, Wyoming, in Flores, R.M., ed., Organics and the Rockies Field Guide, The Society for Organic Petrology Eleventh Annual Meeting, Jackson, Wyoming: Wyoming State Geological Survey Public Information Circular 33, p. 69-81.

\section{Energy Resources on Lands of Native} Americans-Cooperative Investigations by the U.S. Geological Survey, U.S. Bureau of Indian Affairs, and Tribal Governments

\author{
E.A. Merewether and Bruce D. Smith, \\ U.S. Geological Survey, Denver, CO 80225, and \\ Stephen A. Manydeeds, U.S. Bureau of Indian \\ Affairs, Division of Energy and Mineral Resources, \\ 730 Simms Street, Golden, CO 80401
}

\section{Introduction}

The U.S. Geological Survey (USGS) conducts both regional and local studies of the geology, and the energy and minerals resources of the United States. An assessment of the national resources of oil and gas was completed in 1994. An assessment of the national resources of coal was initiated in 1994. For lands of Native Americans in the Western States and Alaska, the USGS, in collaboration with the U.S. Bureau of Indian Affairs (BIA) and the Governments of Indian Reservations and Native Lands, has evaluated resources of coal, oil, natural gas, and nonmetallic and metallic minerals. Most of these investigations developed from a Federal trust responsibility for Tribal Lands and a Memorandum of Understanding (MOU) for coordinating studies of resources and related geologic features for the benefit of Native Americans, both of which are shared by the USGS, the BIA, and the U.S. Bureau of Mines.

The policy of the MOU is implemented by Interagency Agreements between the Division of Energy and Mineral Resources (DEMR) of the BIA and the Geologic Division of the USGS for conducting geotechnical investigations relevant to the identification and description of Tribal resources. Under one agreement, the DEMR supplies funds to the 
USGS for shared computer assets which contribute to the cost-effective development, maintenance, and utilization of digital databases. This funding also allows the development of effective INTERNET (computer network) communications. Another agreement indicates that funds are supplied by the DEMR for OUTREACH activities, to support the cooperative efforts of Tribal Governments and the USGS in compiling and presenting information about resources of the Reservations for national meetings, including those of the American Association of Petroleum Geologists in 1994, the Northwest Mining Association in 1992 and 1993, and the National Indian Energy and Minerals Conferences in 1992-1994.

\section{Studies of Resources on Lands of Native Americans}

Investigations by the USGS of energy, minerals, and aggregate resources on specific Indian Reservations or Native Lands are generally proposed by the Tribal Governments. When a proposed project is approved and funded by the DEMR, it is described and initiated by a Joint Funding Agreement between the Tribal Government and the USGS. Studies by the USGS of natural gas resources on several Indian Reservations have also been funded recently by the U.S. Department of Energy. Tribal Lands where the USGS has investigated energy resources during the past several years are depicted in figure 1 . The geotechnical data supplied to Tribal Governments by the USGS are commonly derived from geologic, geochemical, and geophysical procedures. Resource assessments and related information from many of these investigations have been presented recently in publications as well as in posters and talks for the National Indian Energy/Minerals Conference in Golden, Colo., which was sponsored by the DEMR; at the Jubilee Anniversary Field Conference of the Wyoming Geological Association in Casper, Wyo., which was cosponsored by the DEMR; and at the Annual Meeting of the Northwest Mining Association in Spokane, Wash. Representative products of recent investigations of energy resources on Reservations, which illustrate the usefulness and benefits of cooperative interagency studies, are listed in the following table.

\section{Regional Studies of Resources and Environmental Conditions}

The USGS also conducts assessments, which are funded internally, of the national resources of energy and minerals. Descriptions of these resources in regions of the United States are published by the USGS and used by various Federal, State, and local agencies for land-use planning. Assessments of the conventional oil and gas resources in regions of the United States that include Indian Reservations and Native Lands have been prepared and presented by the USGS, in cooperation with the BIA, as publications (Dolton and others, 1990; Merewether and others, 1994) and as

\begin{tabular}{|c|c|c|l|}
\hline RESERVATION & $\begin{array}{c}\text { STATE } \\
\text { AND AREA }\end{array}$ & $\begin{array}{c}\text { ENERGY } \\
\text { RESOURCES }\end{array}$ & $\begin{array}{c}\text { SELECTED } \\
\text { REFEF QNCES }\end{array}$ \\
\hline \hline Southern Ute & $\begin{array}{c}\text { Colorado, south- } \\
\text { western }\end{array}$ & gas, coal & $\begin{array}{l}\text { Rice and others, } \\
1988 ; \text { S } \text { mdberg, } \\
1988\end{array}$ \\
\hline $\begin{array}{c}\text { Uintah and } \\
\text { Ouray }\end{array}$ & $\begin{array}{c}\text { Utah, } \\
\text { northeastern }\end{array}$ & $\begin{array}{c}\text { gas, oil, } \\
\text { oil-shale, tar- } \\
\text { sand, coal }\end{array}$ & $\begin{array}{l}\text { Benson, 1992; } \\
\text { Fouch and } \\
\text { others, 1992; } \\
\text { Rice and } \\
\text { others, 1992 }\end{array}$ \\
\hline $\begin{array}{c}\text { Ute Mountain } \\
\text { Ute }\end{array}$ & $\begin{array}{c}\text { Colorado, south- } \\
\text { western }\end{array}$ & oil, gas & $\begin{array}{l}\text { Taylor and } \\
\text { Huffma?, 1993 }\end{array}$ \\
\hline $\begin{array}{c}\text { Wind River } \\
\text { Wyoming, } \\
\text { west-central }\end{array}$ & gas, oil, coal & $\begin{array}{l}\text { Barker and } \\
\text { others, 1993; } \\
\text { Johnson and } \\
\text { others, 1993; } \\
\text { Keefer and } \\
\text { Johnson. 1993 }\end{array}$ \\
& & gas & $\begin{array}{l}\text { Nuccio and } \\
\text { others, 1993 }\end{array}$ \\
\hline Rocky Boys & $\begin{array}{c}\text { Montana, } \\
\text { north-central }\end{array}$ & & \\
\hline
\end{tabular}

public lectures. Regions of the United States that include Tribal Lands have also been studied by the USGS to determine potential geologic and geochemical hazards in the natural environment.

\section{Current and Future Studies on Lands of Native Americans}

The USGS, DEMR, and Tribal Governments will likely continue to collaborate in evaluating the resources of energy, minerals, and aggregate on lands of Native Americans. Investigations of the resources on the Reservatior of the Standing Rock Sioux in North Dakota and South Da'ota are in progress. An assessment of the resources of sand and gravel on the Pueblo of Nambe, New Mexico, was initiated in 1994. Studies of the gas resources of Tribal Land by the USGS in cooperation with the U.S. Department of Energy might also continue. Other projects are being planned jointly by the USGS and the Office of Trust and Economic Development of the BIA to investigate environmental corditions, particularly near mines and oil fields, and potential natural hazards on Reservations.

\section{REFERENCES}

Barker, C.E., Bartke, T.C., Hatcher, P.G., and Daws, T.A., 1993, An empirical correlation between coal bed gas with Rock-Eval pyrolysis and ${ }^{13} \mathrm{C}$ NMR results, Cretaceous Mesavarde and Meeteetse Formations, Wind River Basin, Wyoming, in Keefer, W.R., Metzger, W.J., and Godwin, L.H., eds., Oil and gas and other resources of the Wind River Basin, Wyoming: Wyoming Geological Association Special Symposium; Casper, Wyoming; August 14-17, 1993; p. 243-256. 


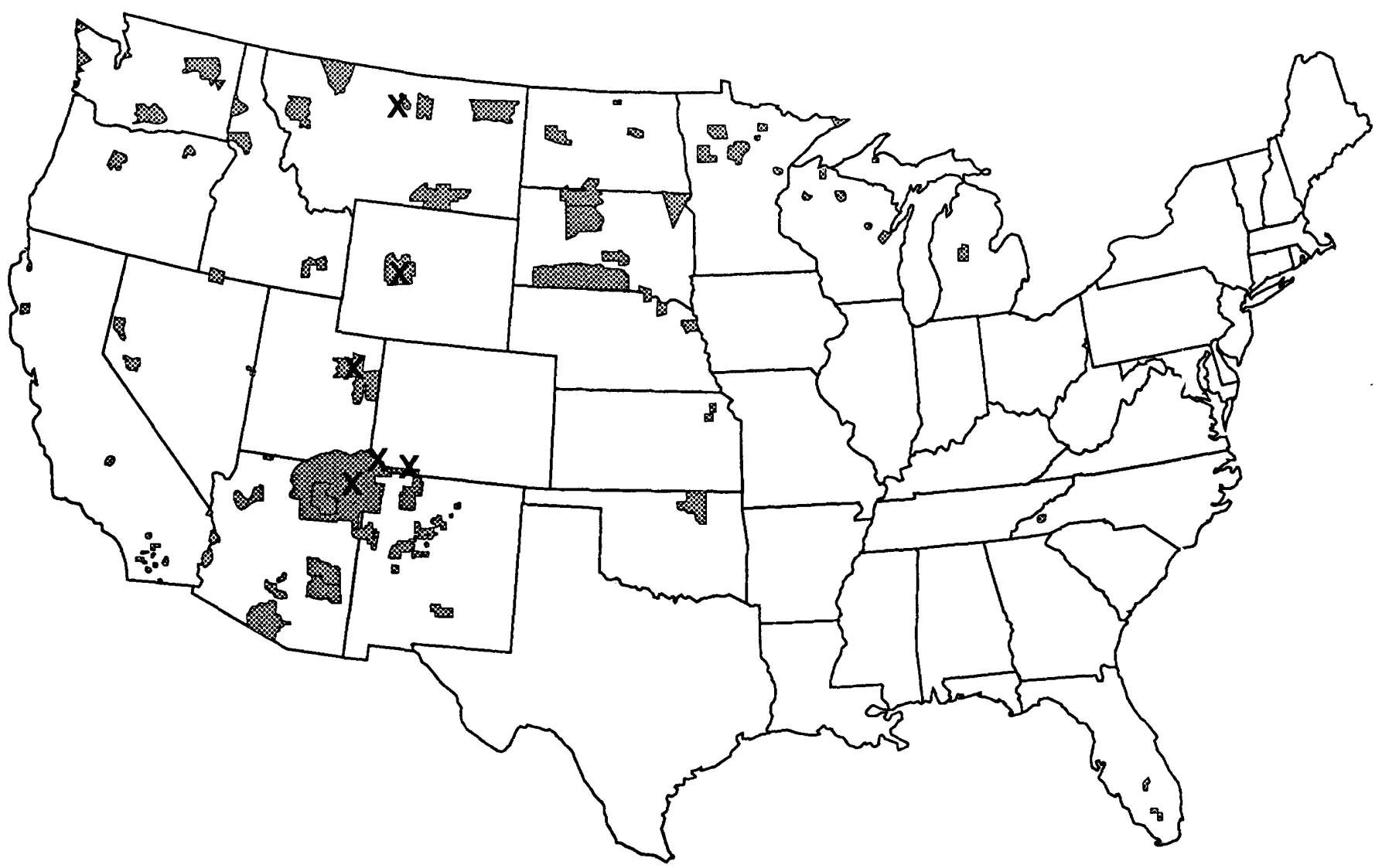

Figure 1 (Merewether and others). Map of the contiguous 48 States of the United States showing many of the Indian Reservations (pattern) and those Reservations where the USGS has recently evaluated energy resources $(X)$.

Benson, A.K., 1992, Determination of depth models through selfconsistent structural modeling to help delineate hydrocarbon traps in the Uinta Basin, in Fouch, T.D., Nuccio, V.F., and Chidsey, T.C., Jr., eds., Hydrocarbon and mineral resources of the Uinta Basin, Utah and Colorado: Utah Geological Association Guidebook 20; Salt Lake City, Utah; Utah Geological Association, p. 219-226.

Dolton, G.L., Mast, R.F., and Crovelli, R.A., 1990, Estimates of undiscovered conventional resources of oil and gas for Federal Lands, and for Indian and Native Lands of the continental United States: U.S. Geological Survey Open-File Report 90-705, $64 \mathrm{p}$.

Fouch, T.D., Nuccio, V.F., Osmond, J.C., MacMillan, Logan, Cashion, W.B., and Wandrey, C.J., 1992, Oil and gas in uppermost Cretaceous and Tertiary rock, Uinta Basin, Utah, in Fouch, T.D., Nuccio, V.F., and Chidsey, T.C., Jr., eds., Hydrocarbon and mineral resources of the Uinta Basin, Utah and Colorado: Utah Geological Association Guidebook 20; Salt Lake City, Utah; Utah Geological Association, p. 9-48.

Johnson, R.C., Clark, A.C., Barker, C.E., Crysdale, B.L., Higley, D.K., Szmajter, Richard, and Finn, T.M., 1993, Coalbed methane potential of the Upper Cretaceous Mesaverde and Meeteetse Formations, Wind River Reservation, Wyoming, in Keefer, W.R., Metzger, W.J., and Godwin, L.H., eds., Oil and gas and other resources of the Wind River Basin, Wyoming: Wyoming
Geological Association Special Symposium; Casper, Wyoming; August 14-17, 1993; p. 215-242.

Keefer, W.R., and Johnson, R.C., 1993, Stratigraphy and oil and gas resources in uppermost Cretaceous and Palencene rocks, Wind River Reservation, Wyoming, in Keefer, W.R., Metzger, W.J., and Godwin, L.H., eds., Oil and gas and othor resources of the Wind River Basin, Wyoming: Wyoming Geological Association Special Symposium; Casper, Wyoming; August 14-17, 1993; p. 71-85.

Merewether, E.A., Dolton, G.L., and Smith, B.D., 1994, Resources of oil and gas on Indian and Native lands of the United States, in Anderson, R.C., ed., The oil and gas opprrtunity on Indian lands-Exploration policies and procedure: U.S. Bureau of Indian Affairs General Publication G-94-3, p. 5-19.

Nuccio, V.F., Finn, T.M., and Crysdale, B.L., 1993, Energy resource evaluation of the Rocky Boys Reservation, north-central Montana: U.S. Geological Survey Administrative Report BIA 34-VII-1993, 54 p.

Rice, D.D., Fouch, T.D., and Johnson, R.C., 1992, Influence of source rock type, thermal maturity, and mig"ation on composition and distribution of natural gases, Uin ${ }^{+a}$ Basin, Utah, in Fouch, T.D., Nuccio, V.F., and Chidsey, T.C., Jr., eds., Hydrocarbon and mineral resources of the Uinta Basin, Utah and Colorado: Utah Geological Association Guidel ook 20; Salt Lake City, Utah; Utah Geological Association, p. 95-109. 
Rice, D.D., Threlkeld, C.N., Vuletich, A.K., and Pawlewicz, M.J., 1988, Identification and significance of coal-bed gas, San Juan Basin, northwestern New Mexico and southwestern Colorado, in Fassett, J.E., ed., Geology and coal-bed methane resources of the northern San Juan Basin, Colorado and New Mexico: Rocky Mountain Association of Geologists, Denver, Colorado, 1988, p. 51-59.

Sandberg, D.T., 1988, Coal resources and coal-bed geometry, Fruitland Formation, Southern Ute Indian Reservation, Archuleta and La Plata Counties, Colorado, in Fassett, J.E., ed., Geology and coal-bed methane resources of the northern San Juan Basin, Colorado and New Mexico: Rocky Mountain Association of Geologists, Denver, Colorado, 1988, p. 39-50.

Taylor, D.J., and Huffman, A.C., Jr., 1993, Ute Mountain Ute Indian Reservation of southwestern Colorado and northwestern New Mexico-Subsurface evaluation using multichannel seismic reflection data: U.S. Geological Survey Administrative Report, 37 p.

\section{Conventional Energy Resources from the Federal Outer Continental Shelf, U.S.A.}

\author{
Pulak K. Ray and George Carpenter, \\ Minerals Management Service, 381 Elden Street, \\ Herndon, VA 22070
}

The Minerals Management Service of the U.S. Department of the Interior is responsible for the environmentally safe planning and management of the exploration and development of natural gas and oil from the Federal Outer Continental Shelf (OCS: beyond the StateFederal boundary). Since 1954 approximately $\$ 56$ billion in lease sale bonuses and about $\$ 44$ billion in oil and gas royalties ( $\$ 23.9$ billion in gas and $\$ 20.5$ billion in oil) have been generated from the OCS (MMS, 1993a). Even though bonuses from lease sales of the OCS have been significantly lower in recent years, the OCS still produces more than $\$ 2.5$ billion per year in gas and oil revenue, primarily from the Gulf of Mexico.

The demand for natural gas and oil in the United States between 1990 and 1992 has ranged from 19.3 to 19.8 TCFG (trillion cubic feet of gas) per year and from 16.9 to 16.7 MMBO (million barrels of oil) per day. An average of 8.0-10.4 percent of the annual demand for gas and 46-47 percent of the daily demand for oil was met through imports, over the same period of time (API, 1994). The production of gas and oil from the OCS accounts for about 27 percent of total U.S. gas production and about 13 percent of U.S. oil production (MMS, 1993b).

The remaining proved gas reserve of the OCS has been steadily decreasing since 1986 . A proved remaining reserve of 31.25 TCF of OCS gas in 1992 accounted for about 19.0 percent of the total U.S. gas reserve (MMS, 1993c). The remaining proved oil reserve of the OCS also shows a decreasing trend since 1985. In 1992, a proved OCS oil reserve of 3.28 billion barrels for th: OCS accounted for about 13.3 percent of total U.S. proved remaining reserve. In the late 1980's and early 1990's, an average of 12.8 percent of proved gas reserve and 8.6 percent of proved oil reserve has been produced annually. However, annual reserve depletion for gas and oil reserve during the same period is reported to be 7.2 percant and 6.4 percent, respectively. The apparent discrepancies are due to annual reserve additions through reserve growth and additions of proved reserves from newly esta $b$ lished fields. Annually, 5.6 percent of proved gas reserve and 2.2 percent of proved oil reserve are added throl gah this process.

To ensure environmentally sensitive planring of exploration and safe development, MMS follows a multistage action plan. MMS spent about $\$ 227.00$ mil"ion for environmental studies program over the last 10 yerrs. The studies include general biological studies, endangered species studies, fate/effects study, socioeconomic studies, and physical oceanographic and air quality studies.

Environmental studies projects are distributed among the four Regions of the Federal OCS: Alaska, Pacific, Gulf of Mexico, and Atlantic. The results of these studies are incorporated into any decision-making process related to the selection of area to be offered for lease. T] is protected from adverse impact to the environment by a series of meaningful regulations, which not only cover pre-lease activities, but also provide safeguards during the exploration and development stages. The safety inspection program of the MMS ensures safety not only' to the environment but also to the workers involved in the production from the offshore platforms. A low and improving accident and oil spill rate resulting from offshore production attests to the effects of the safety regulations and improved technology. The oil spill (from OCS platforms and pipelines) records of the offshore gas and oil operation over the last 30 years indicate a significant reduction in the oil spill rates: for spills over 2.0 barrels/incident, the average spill rate in the 1960's was 155 barrels/1 MMBO (million barrels of oil) produced; in the 1970 's and 1980's the rate dropped respectively to 41 barrels/ $1 \mathrm{MMBO}$ and 12 barrels/1 MMBO produced. The number of accidents were also reduced to half betv'een the 1970's (16 spills>200 MMBO) and 1980's (8 spills $>200$ MMBO) (MMS, 1992). If one considers the number of structures $(3,790$ in 1990) operating in the OCS, it is easy to conclude that the amount of oil introduced into the marine environment from OCS gas and oil operctions is significantly lower than that from tankering or natural seepage. Natural seepage contributes $50-500 \mathrm{bbl} /$ day in the Santa Barbara Channel alone (API, 1992). In the 10year period from 1982 to 1991 , tankers spilled more than 
70 percent more oil into U.S. marine waters (per million barrels handled) than did OCS operations.

An essential component of any strategic planning for gas and oil exploration and development of a province is an estimate of the amount of undiscovered gas and oil resources and their geographic distribution. The MMS, in cooperation with the U.S. Geological Survey, periodically conducts an assessment of the Nation's undiscovered oil and gas resources. The MMS provides the estimates for the OCS. The last OCS assessment, conducted in 1987 and updated in 1990, indicated the risked mean economically recoverable undiscovered gas and oil resource to be 75.4 TCF of gas and 10.9 BBO (billion barrels of oil), respectively. Currently, MMS and USGS are coordinating an assessment of the undiscovered oil and gas resources of the OCS State waters, and the onshore United States, respectively. Utilizing current information, many new plays have been identified in various areas of the OCS. For reporting purposes, the plays have been classified into three groups: established (plays with numerous discoveries), frontier (plays with limited discoveries), and conceptual plays (Ray and Houseknecht, 1994). The resources are being estimated utilizing a "super population" concept. The results of this assessment are expected to be released in 1995.

In summary, the Federal OCS plays a significant role in the Nation's energy supply. For the OCS to remain a steady supplier of energy for a long period of time, the annual reserves depletion needs to be reduced through annual addition of larger proved reserves. The additional proved reserves may come from exploration and development of leased areas, conversion of unproved reserves to proved reserves, and establishment of new plays. Some new plays, such as subsalt and deep-water plays in the Gulf of Mexico, have already been established, but the economic risks associated with such plays are higher. Although the production from the Federal OCS alone will likely not be able to totally wipe out the import of oil and gas, discovery of a significant amount of estimated undiscovered resources from the OCS coupled with onshore and offshore reserves development and prudent planning and conservation measures may significantly reduce our Nation's dependence on energy import.

\section{REFERENCES}

API, 1992, Seismic safety requalification for offshore platforms. 1994, Basic petroleum data book, May 1994.

MMS Report, 1992, Accidents associated with oil and gas operations: MMS 92-0058.

MMS Report, 1993a, Mineral revenues. 1993b, Federal offshore statistics, 1992: MMS 93-0066. 1993c, Reserves report; Gulf of Mexico and Pacific Regions.

Ray, P.K., and Houseknecht, D.W., 1994, National Assessment of oil and gas resources: Geotimes, v. 39, no. 5, p. 17-19.

\section{Energy Resources and Environmertal Issues in the U.S. Gulf Coast}

\author{
C.J. Schenk, R.J. Viger, and R.M. Pollastro, \\ U.S. Geological Survey, Denver, CO 80225
}

Oil and gas resources for 100 hydrocarhon plays in the Gulf Coast, representing productive or potentially productive stratigraphic units ranging from Triassi- to Pleistocene in age, were assessed for the U.S. National A ssessment. The Gulf Coast region includes southwest Alabama, southern Mississippi, southern Arkansas, Louisiana, Florida, and south and east Texas. The region is divided into four hydrocarbon provinces: Province 47 (coastal plain of Texas and southern Louisiana), Province 48 (East Texas), Province 49 (Mississippi-Louisiana salt basins), and Province 50 (Florida peninsula); for the assessment Provinces 48 and 49 were combined. The USGS assessment includes the onshore areas of the Gulf Coast and State waters; Minerc's Management Service is responsible for the oil and gas assessment in Federal waters. Of the 100 plays, 46 plays are located in Province 47,47 plays are located in the combined $48 / 49$ province, and 7 plays are in Province 50. The plays include conventional and unconventional oil and gas resources.

Oil and gas plays are geologically defired groupings of oil or gas accumulations based on similarit ${ }^{\circ}$ s of hydrocarbon source, migration, traps, reservoirs, and type of hydrocarbon. The assessment includes an analysis of trap distribution, discovery history, discovery rat $\mathrm{s}$, drilling footage, and density, which led to predictions of whether significant ( $>1$ million barrels of oil equivalent) a cumulations of undiscovered oil and gas exist in each play. Analog plays were used to provide an estimate of the undi scovered oil and gas potential for those plays that did not have production data (hypothetical plays).

Significant future additions to the U.S. gas resource base across the Gulf Coast are predicted to come mainly from intermediate to deep conventional gas plays and from unconventional gas plays. The deep gas plays include parts of the Tuscaloosa Formation (Upper Cretaceous), lower and upper parts of the Wilcox Group (Paleocene and Eocene), mid-Eocene sandstones, Yegua Formation (Eocene), Jackson Formation (Eocene), Virksburg Formation (Oligocene), Frio Formation (Oligocen), and Miocene in the western Gulf, the hypothetical Wertern Gulf Norphlet Formation, Smackover Formation, an 1 Cotton Valley Group (Upper Jurassic) gas plays, the deep Norphlet, Smackover, and Cotton Valley plays in the salt basins, and the deep Norphlet in the eastern Gulf portion of Province 49. Excellent gas potential is predicted in many plays at intermediate depths, including the Gilmer Limestone (Upper Jurassic), the James Limestone (Lov'er Cretaceous), Lower Cretaceous shelf-edge carbonates and Upper Cretaceous sandstones in the western Gulf, the Wilcox, Yegua, 


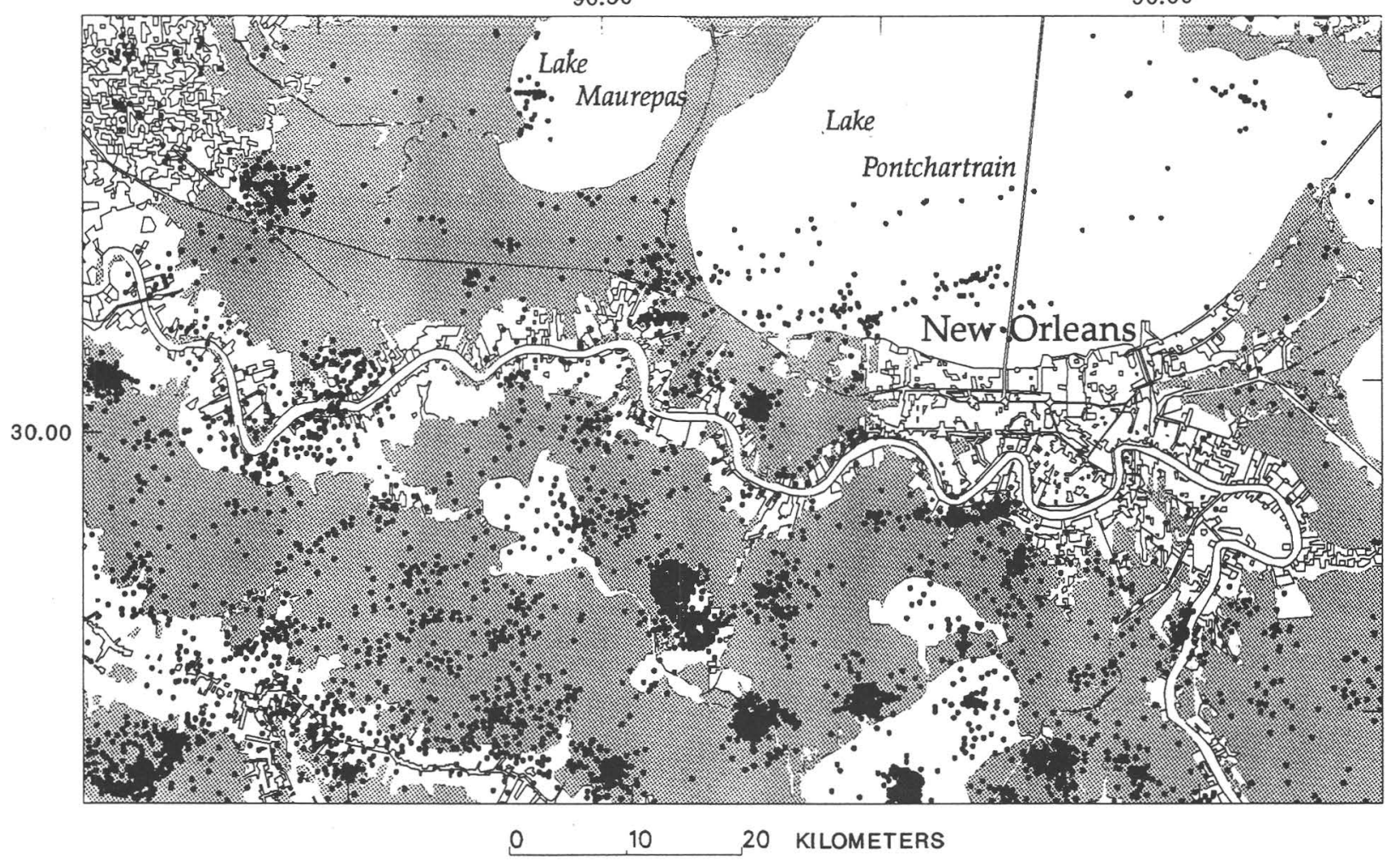

Figure 1 (Schenk and others). Map of oil and gas wells (dots) in areas classified as wetlands, New Orleans area, Louisiana. White areas that are not water bodies are classified as agricultural lands. Much of southern Louisiana is classified as wetland (shaded area), and thousands of wells have been drilled in these fragile lands. Development of deep gas resources in the future will further increase pressure to drill in wetlands and other fragile coastal ecosystems.

and Frio in the western Gulf, and unconventional gas accumulations in Cotton Valley, Hosston and Travis Peak Formations (Lower Cretaceous), and Austin Chalk (Upper Cretaceous) reservoirs.

Shallow oil plays, because of the intense exploration history and drop-off in discovery rates throughout the Gulf Coast, do not have significant potential for significant future additions to the U.S. oil resource base. Intermediate depth oil plays have excellent potential, including plays in the Tuscaloosa, Woodbine Formation (Upper Cretaceous), Cretaceous carbonates, and the Wilcox. Several oil plays updip from the regional peripheral fault zones have good to excellent resource potential, including the Norphlet, Smackover, and Haynesville Formations (Upper Jurassic). However, significant additions to the U.S. oil resource base will probably come from unconventional oil plays, such as the fractured Upper Cretaceous Austin Chalk and Buda Limestone in the Western Gulf province.

Environmental problems related to energy resources in the Gulf Coast will continue to be associated with drilling in wetlands and other fragile coastal ecosystems. The development of these fragile lands is the focus of current research along the Gulf Coast. Other environmental problems include disposal of oil and gas field fluids, and the handling of $\mathrm{H}_{2} \mathrm{~S}$ associated with many of the deep conventional gas reservoirs. Another problem facing the future development of unconventional resources is that hundreds and perhaps thousands of development wells may be necessary to recover these resources, presenting a serious challenge to develop these resources in an environmentally sound manner. 


\section{Energy Studies on Native American Lands Funded by U.S. Department of Energy- Near-Surface Methane and Hydrocarbon Occurrence, Southern Ute Indian Reservation, Colorado, and Jicarilla Apache Indian Reservation, New Mexico}

Robert S. Zech, Jennie L. Ridgley, Kimberley I. Cunningham, G. Michael Reimer, A. Curtis Huffman, Jr., Steven M. Condon, and Bill S. Larson, U.S. Geological Survey, Denver, CO 80225

Oil and gas resources on Indian lands in southern Colorado and northern New Mexico are an important part of the Tribal economies. The Southern Ute Indian Reservation, Colorado, and the Jicarilla Apache Indian Reservation, New Mexico (fig. 1), contain potential and proven hydrocarbon resources that occur in two different geologic settings: (1) folded rocks (structures, commonly faulted) that concentrate the hydrocarbons into discrete locations; and (2) stratigraphic traps (areas where reservoir rocks pinch-out).

Standard techniques for exploring for hydrocarbon accumulations may involve the acquisition and interpretation of data from several sources: drilling, subsurface well logs, geophysical reflection seismic lines, field examination of rock outcrops, and geochemical analyses of rock samples. These techniques are generally very costly. A less expensive technique is the soil-gas survey.

A soil-gas survey is a type of exploration technique that examines the amount of light hydrocarbon (methane, ethane, and propane) and helium gas in the near-surface (1-2 meters) environment. Over the past two decades, studies of methane in the soil have shown that soil-gas anomalies, if properly interpreted, reflect leakage from subsurface oil and gas accumulations. This effect is known as microseepage. From 1985 to 1987 the USGS acquired several soil-gas profiles in southern Colorado and northern New Mexico in cooperation with the Bureau of Indian Affairs and the Southern Ute Indian Tribe. These profiles show a direct correlation between elevated amounts of light hydrocarbon gases and helium and the known occurrences of oil and gas deposits at four producing fields. Each of these fields contains gas or oil deposits that are structurally controlled by folding and faulting.

The previous soil-gas surveys were principally concerned with testing the soil-gas method by looking at soilgas distributions in areas known to contain hydrocarbon deposits. The preliminary results indicated a favorable correlation of soil-gas anomalies with accumulations of hydrocarbons in certain structural settings. This suggests that the method may provide useful information in undrilled areas on the Reservations containing suitable accumulations.

The soil-gas techniques have demonstrated repeatable results. The quality of repeatable results is necessary in establishing baseline information for the structurally controlled deep oil and gas resources. The baseline information will allow us to compare the natural (pre-drilling) background with post-development soil-gas concentrations for both types of resource occurrence.

This project, in cooperation with the U.S. Department of Energy, will capture the soil-gas and geologic data and use a geographic information system (GIS) analysis to assess various spatial relationships. These include location of known resources, structure (folding, faulting, and fracturing), drilling, stratigraphy, and seismic line information. Use of GIS will allow rapid evaluation of the data and will focus on evaluation of undrilled areas and the comparison of predrilling and post-drilling soil-gas levels. Data and results from this study may be used as an exploration tool for hydrocarbon in other areas, and it may also be applied to the knowledge base of the global methane budget. 


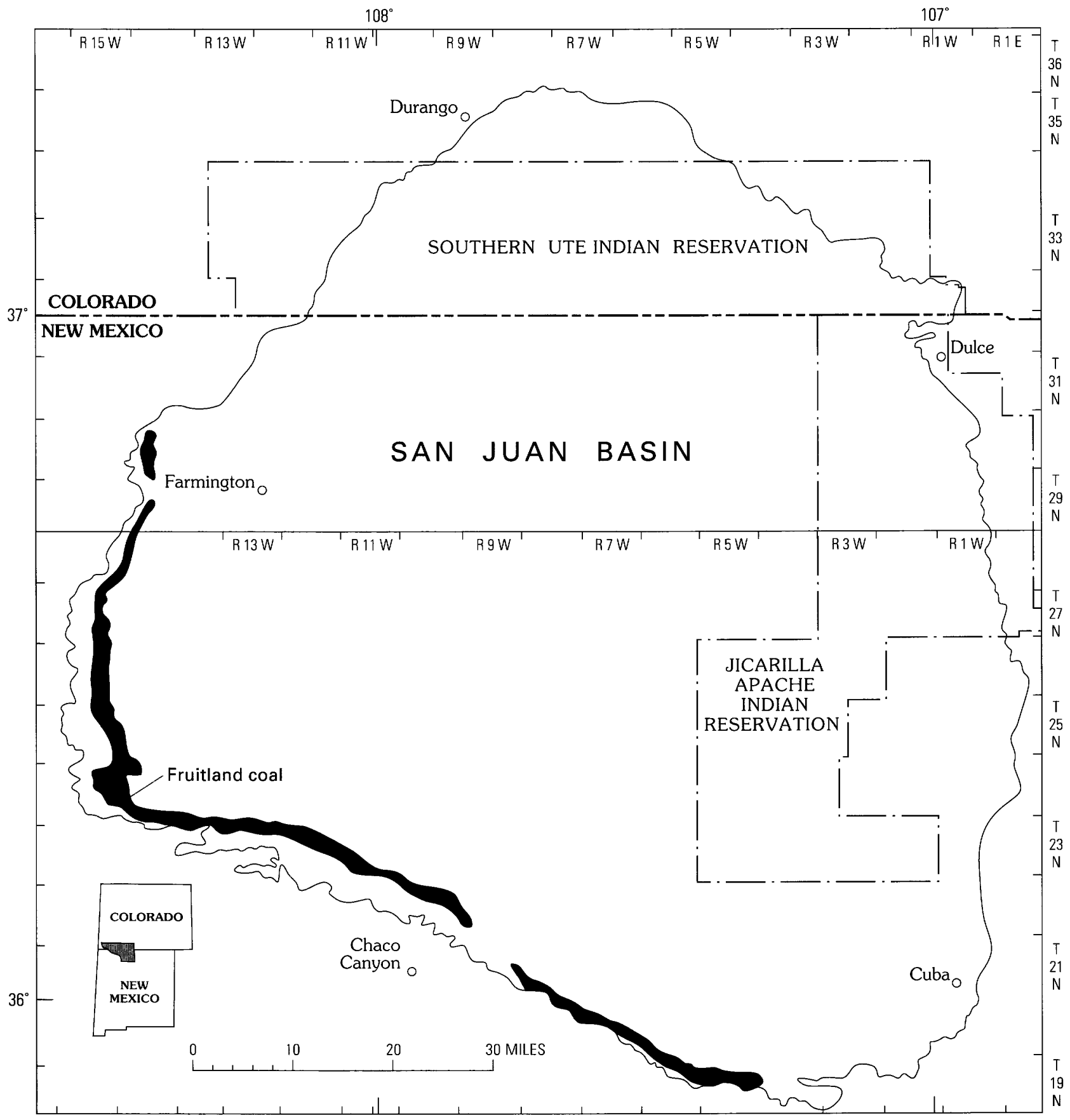

Figure 1 (Zech and others). Location of the Southern Ute and Jicarilla Apache Indian Reservations in the San Juan Basin, Colnrado and New Mexico. 


\section{Availability and Quality of Energy Resources \\ Domestic Unconventional}

\section{Resource and Climate Implications of Natural Gas Hydrates}

\author{
William P. Dillon, ${ }^{1}$ James S. Booth, ${ }^{1}$ Timothy \\ S. Collett, ${ }^{2}$ Keith A. Kvenvolden, ${ }^{3}$ Dwight $F$. \\ Coleman, ${ }^{1}$ Myung W. Lee, ${ }^{2}$ William J. Win- \\ ters, ${ }^{1}$ and Kristen Fehlhaber ${ }^{1}$ ( ${ }^{1}$ U.S. Geological \\ Survey, Woods Hole, MA 02543; ${ }^{2}$ USGS, Denver, \\ CO 80225; ${ }^{3}$ USCS, Menlo Park, CA 94025)
}

\section{Introduction}

Natural gas hydrate is a solid, crystalline, ice-like material that is formed of water and gas (mostly methane) molecules. It is stable at the temperature and pressure conditions that exist near and just beneath the sea floor where water depths exceed 300 to 500 meters, and also is stable in conjunction with permafrost at high latitudes. Worldwide, gas hydrate is estimated to hold about $10^{19}$ grams of organic carbon in the form of methane (Kvenvolden, 1993). This represents an amount of organic carbon that is twice as much as in all other fossil fuels on Earth (conventional natural gas, oil, and coal) and an amount of methane that is about $10^{3}$ times as much as exists in the atmosphere, where methane is $\approx 20 \times$ as effective a greenhouse gas as $\mathrm{CO}_{2}$ (on a molar basis). Gas hydrate is an important topic for study for three reasons: (1) the great volume of methane that it holds, which indicates a potential as a future energy resource, (2) its function as a source or sink for atmospheric methane, which may influence climate, and (3) its effect on sediment strength, which can initiate landslides on the slope and rise.

\section{Atlantic Margin Mapping}

We have mapped both the volume of hydrate (fig. 1) and thickness of the hydrate-cemented layer off the U.S. East Coast (Dillon and others, 1994) using seismic-reflection data (Lee and others, 1993). Some concentrations of hydrate are correlated to locations of greatest sedimentation. Other hydrate concentrations, located near salt(?) diapirs, may be fed by deep thermogenic gas that migrates up faults. Thinning of the hydrate layer across diapirs may result from chemical and (or) thermal controls. Hydrate apparently fills sediment pore space and reduces permeability, and thus hydrate-cemented sediments act as seals for gas traps. The gas that forms th ? hydrate of the seal, as well as the gas within the hydrate-sealed trap, may be recovered by reducing the pressuri, which would cause the breakdown of hydrate and the release of gas to recharge the trap. A relationship between hydrate breakdown and mass movement is evidenced by (1) thinning of the hydrate layer beneath landslide scars, and (2) increased frequency of the tops of landslide scars at water depths equal to the top of the hydrate stability zone. Landslides may release gas from hydrate (by reducing pressure and allowing breakdown of the hydrate) and' release the gas trapped beneath the hydrate (by rupturing the seal). Thus landslides may trigger a transfer of gas tc the atmosphere, inducing climate change (Paull and others, 1991).

The volume of gas held in the gas hydrate can be estimated from the map of hydrate volume (fig. 1). For example, within the area delimited by the $30 \mathrm{~m}$ hydrate contour on the Blake Ridge (southern part of the area of fig. 1 , south of lat $32^{\circ} \mathrm{N}$.), an area of $3,050 \mathrm{~km}^{2}$, we estimate a volume of $1.12 \times 10^{11} \mathrm{~m}^{3}$ of hyd ate, which contains $1.8 \times 10^{13} \mathrm{~m}^{3}$ (630 TCF) of methane.

\section{Arctic Distribution}

Significant quantities of naturally occurring gas hydrate also have been detected in many regions of the Arctic, including Siberia, the Mackenzie River delta, and the North Slope of Alaska. On the N'orth Slope, the methane-hydrate stability zone is areally extensive beneath most of the coastal plain province and has thicknesses greater than $1,000 \mathrm{~m}$ in the Prudhoe Bay area (Collett, 1993). Gas hydrate has been inferred to crcur in 50 North Slope exploratory and production wells on the basis of well-log responses that were calibrated tc the signature of an interval in a well where gas hydrate was recovered in a core. Most North Slope gas hydrate is restricted to the area overlying the eastern part of the Kuparuk River oil field and the western part of the Prudhoe Bay o:1 field, where the volume of gas within the hydrate is estimated to be about $1.0 \times 10^{12}$ to $1.2 \times 10^{12} \mathrm{~m}^{3}$ (37 to $44 \mathrm{TCF}$ ). This is about twice the volume of conventional gas in the Prudhoe Bay field.

\section{Laboratory Studies}

Laboratory studies are necessary to understand the processes by which gas hydrate may be concentrated on the continental margin and to develop tools (such as acoustic models) that facilitate recognition and resource analysis of 


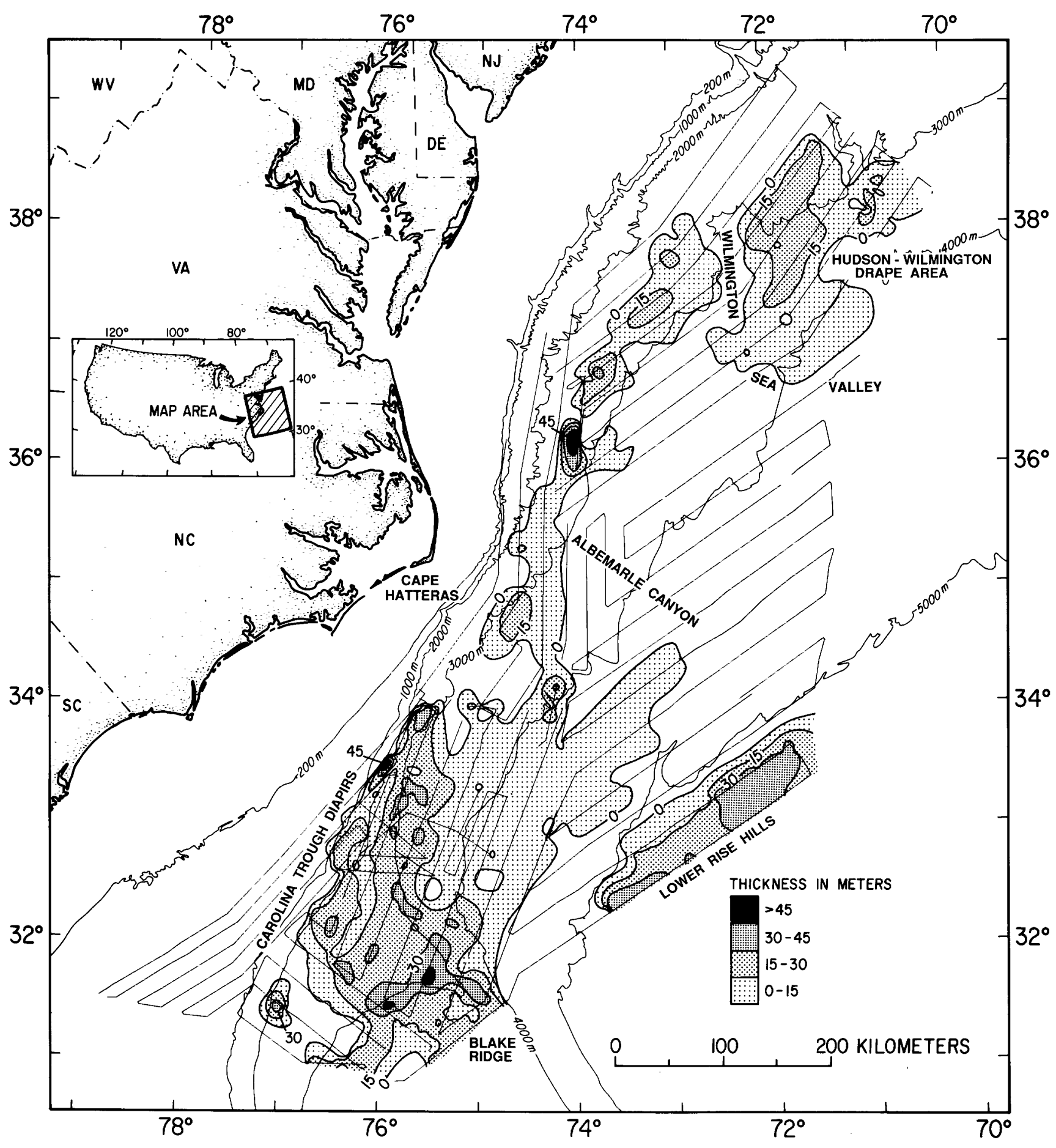

Figure 1 (Dillon and others). Isopach map showing contours that indicate total amount of solid gas hydrate existing within the sediments of the U.S. Atlantic continental margin, calculated from seismic-reflection profiling data. This isopach map is considered to represent the total volume of pure hydrate that is distributed through the sediments as disseminated grains, veins, and nodules. That is, it can be thought of as the amount that would appear if all of the hydrate were extracted from the sediment and piled upon the sea floor. In actuality, the hydrate is distributed in a zone between the sea floor and a lower boundary of hydrate stability that occurs at varying depths, as much as many hundred meters beneath the sea floor. Light solid numbered contours are water depths in meters; light solid straight lines represent seismic track lines. 
these offshore hydrate deposits. The USGS has begun using a computer-controlled test system in which gas hydrate is formed and decomposed in sediment samples under simulated in-situ (deep-sea or arctic) conditions. Possible mechanisms of natural concentration are also being simulated, including (1) an accumulating sediment column, (2) cyclic sea-level change, (3) faulting and fluid migration, and (4) trapping of free gas beneath a hydrate seal. Experiments are being conducted to assess the impact of gas hydrate on sediment behavior, particularly with respect to slope failure and other potential geohazards, and to estimate the amounts and rates of release of methane into the atmosphere in response to geologic phenomena.

\section{Conclusions}

USGS gas hydrate studies indicate that a variety of conditions and geologic processes cause the concentration of gas hydrate in arctic and ocean-floor settings. Extremely large volumes of gas are held in such accumulations, and free gas is trapped where hydrate-bearing sediments form a seal. Hydrate may be a significant future energy resource and also may represent a control on climate change. It probably is important to the stability of seafloor sediments. Studies of gas hydrate occurrences in the natural environment will increase our understanding of these phenomena and of the traces they leave on the geologic record. Laboratory studies are required to understand hydrate processes and to provide calibration of the effects of hydrate on remote sensing measurements that are used in field studies, especially well logging and seismic-profiling measurements.

\section{Acknowledgments}

We wish to acknowledge funding from the U.S. Department of Energy, Morgantown Energy Technology Center.

\section{REFERENCES}

Collett, T.S., 1993, Natural gas hydrates of the Prudhoe Bay and Kuparuk River area, North Slope, Alaska: American Association of Petroleum Geologists Bulletin, v. 77, p. 793-812.

Dillon, W. P., Lee, M.W., and Coleman, D.F., 1994, Identification of marine hydrates in situ and their distribution off the Atlantic coast of the United States: Annals of the New York Academy of Sciences, v. 715, International Conference on Natural Gas Hydrates, p. 364-380.

Kvenvolden, K.A., 1993, Gas hydrates-Geological perspective and global change: Reviews of Geophysics, v. 31, p. 173-187.

Lee, M.W., Hutchinson, D.R., Dillon, W.P., Miller, J.J., Agena, W.F., and Swift, B.A., 1993, Method of estimating the amount of in situ gas hydrates in deep marine sediments: Marine and Petroleum Geology, v. 10, p. 493-506.

Paull, C.K., Ussler, William, III, and Dillon, W.P., 1991, Is the extent of glaciation limited by marine gas hydrates?: Geophysical Research Letters, v. 18, p. 432-434.

\section{Low-Permeability (Tight) Gas Reservoirs- An Environmentally Acceptable Major Source of Energy for the 21st Century?}

\author{
B.E. Law, C.W. Spencer, R.A. Crc'elli, and \\ J.W. Schmoker, U.S. Geological Survey, Denver, \\ CO 80225, R.T. Ryder, U.S. Geolo sical Survey, \\ Reston, VA 22092, W.M. Sutherland, \\ U.S. Bureau of Land Management, P.O. Box 1869, \\ Rock Springs, WY 82902-1869, and K.H. Frohne, \\ U.S. Department of Energy, P.O. Box 880, Morgan- \\ town, WV 26507
}

Low-permeability (tight) gas reservcirs are gas-bearing rocks that usually have an exceptionally low gas transmissibility flow and, until recently, have been marginally economic. In the literature, these reservoirs contain gas in unconventional accumulations that are var' ously referred to as "tight gas," basin-centered gas, or continuous gas. In the United States, tight gas reservoirs are estimated to contain in-place resources of at least 420 trillion cubic feet (TCF) and possibly more than 5,000 TCF. Of these in-place gas resources, 200 to more than $550 \mathrm{TCF}$ are estimated to be recoverable. Annual production from this large gas resource has been increasing for several years. For example, production of gas from tight reservoirs in the United States in 1990 was about 1.7 TCF, or about 10 percent of the total gas produced in the United States (National Petroleum Council, 1992), and the proportion of gas produced from tight reservoirs likely will steadily increase as the markets for this relatively clean energy source expand. Many anticipate that most surface vehicles will be powered by natural gas in the 21 st century.

Tight gas reservoirs occur in nearly all petroleum provinces. The distribution of the principal tight gas reservoirs in the United States is shown in figure 1. However, the geographic distribution of these gas accumulations is only partially known. Many additional areas in Alaska and the Western United States probably contain large gas accumulations in tight reservoirs. For example, an overpressured basin-centered gas accumulation $\mathrm{l}$ as only recently been recognized below the large basalt-covered area of eastern Washington (Law and others, 1994). In other basins known to contain tight reservoirs, such as the Appalachian, Anadarko, and onshore Gulf Coast Basins, the spatial distribution of tight gas reservoirs is poorly known.

In the various petroleum provinces tight gas reservoirs occur at virtually all depths and in a variety of rock types that include sandstone, siltstone, she'e, sandy carbonate rocks, limestone, and chalk. Tight gas reservoirs may be thick and areally extensive or thin ant areally limited. In normal (conventional) gas accumulations, the gas is concentrated in discrete structural or stratigraphic traps, 
whereas gas in tight reservoirs occurs as regionally pervasive accumulations that are usually abnormally pressured and are mostly independent of structural and stratigraphic traps. Artificial stimulation, such as hydraulic fracturing, is usually needed to produce the gas, unless extensive natural fracturing is present. For additional information on the distribution and characteristics of tight gas reservoirs, the reader is referred to Finley (1984), Masters (1984), Spencer and Mast (1986), Spencer (1989), Dutton and others (1993), and Law and Spencer (1993).

In general, there are two main types of gas accumulations in tight reservoirs: (1) thermogenic, and (2) biogenic gas accumulations. Thermogenic gas accumulations are the more common and economically important type. In thermogenic gas accumulations, the gas has been generated from source rocks that have been subjected to temperatures in excess of 190 to $200^{\circ} \mathrm{F}$. Thermogenic gas accumulations are either abnormally overpressured or underpressured with respect to normal, hydrostatic pressures and the accumulations commonly occur at depths greater than $8,000 \mathrm{ft}$. Examples of large thermogenic gas accumulations are those in the Greater Green River, Piceance, Uinta, and San Juan basins in the Western United States and the Appalachian and Black Warrior basins in the Eastern United States (fig. 1). In contrast, biogenic gas accumulations are produced by microorganisms. The source rocks for these biogenic accumulations have never experienced temperatures higher than $190^{\circ} \mathrm{F}$. They are always underpressured and commonly occur at depths less than $2,000 \mathrm{ft}$. Examples of large biogenic accumulations are those in the northern Great Plains and the eastern plains (fig. 1). Exceptions to these generalized thermal conditions sometimes occur in areas that have experienced considerable uplift and erosion along with changes in the fluid flow history.

Tight reservoirs mostly produce gas and condensate (a hydrocarbon mixture that is gaseous in the ground but condenses to a fluid when produced) with little or no water. The gas contained in tight reservoirs is predominantly methane (typically more than 85 percent) with very low amounts of ethane and higher molecular weight hydrocarbons. Condensate is often associated with the gas in various proportions, sometimes as much as 60 barrels per million cubic feet of gas but more commonly, 10 to 15 barrels per million cubic feet of gas. From an economic perspective, the amount of condensate produced with the gas has significant value, making some low-volume gas wells economically viable. Other gas components such as carbon dioxide, nitrogen, and hydrogen sulfide may be present in amounts as high as 5-7 percent. In most cases the gas and condensate are derived from organic matter contained in interbedded coal and shale or from disseminated organic matter in the gas reservoir.

The wide range of gas resource estimates in tight reservoirs (from 420 to $5,000 \mathrm{TCF}$ ) is primarily due to uncertainties concerning the geographic distribution of the reservoirs, the nature of the gas accumulations, differences in assessment methodologies, and the number of basins, formations, and wells evaluated. Resource assessment methodologies utilized in conventional oil and gas assessments are inappropriate for tight gas reservoirs because of the unusual mode of gas occurrence. In the current U.S. Geological Survey assessment of these gas accumulations, each accumulation is regarded as a collection of hydrocarbon-containing cells. A probability distribution for the number of potentially productive, but untested cells in a play is developed from geologically based estimates of numbers of untested cells and the fraction of untested cells expected to be productive. A probability distribution for estimated recovery from potentially productive, untested cells in a play is developed using established production within the play or from an analog play if necessary. These probability distributions comprise the geologic model and input to the resource-assessment calculation system.

Gas from unconventional tight reservoirs is rapidly emerging as a major source of energy. Within the last year, activity surrounding tight gas reservoirs has increased sharply because of the emphasis on gas as a clean and efficient fuel and because of the application of new drilling and completion techniques. As a consequence of the increased activity, U.S. Bureau of Land Management and industry teams have been strongly challenged to generate appropriate environmental and planning documentation, as required by law. The widespread occurrence of gas in tight reservoirs, and the necessity of drilling closely spaced wells in order to effectively drain the gas resource, will require access roads, drilling sites, and gas pipeline systems over hundreds of square miles. Such development can conflict with other surface activities. Those conflicts are probably nowhere better demonstrated than in the Rocky Mountain region, where drilling activity competes with scenic, recreational, and wildlife interests and affects issues related to soil conservation, water quality, and slope stability.

Of all the different types of unconventional gas resources, gas in tight reservoirs has the greatest potential of significantly contributing to the Nation's energy needs into the next century. Before this large gas resource is exploited, the environmental issues previously noted need to be addressed in order to avoid permanent damage to the ecosystem. Working together, however, industry, government, and special interest groups can mitigate many of the problems related to the development of gas in tight reservoirs.

\section{REFERENCES}

Dutton, S.P., Clift, S.J., Hamilton, D.S., Hamlin, H.S., Hentz, T.F., Howard, W.E., Akter, M.S., and Laubach, S.E., 1993, Atlas of major low-permeability gas reservoirs in the continental United 

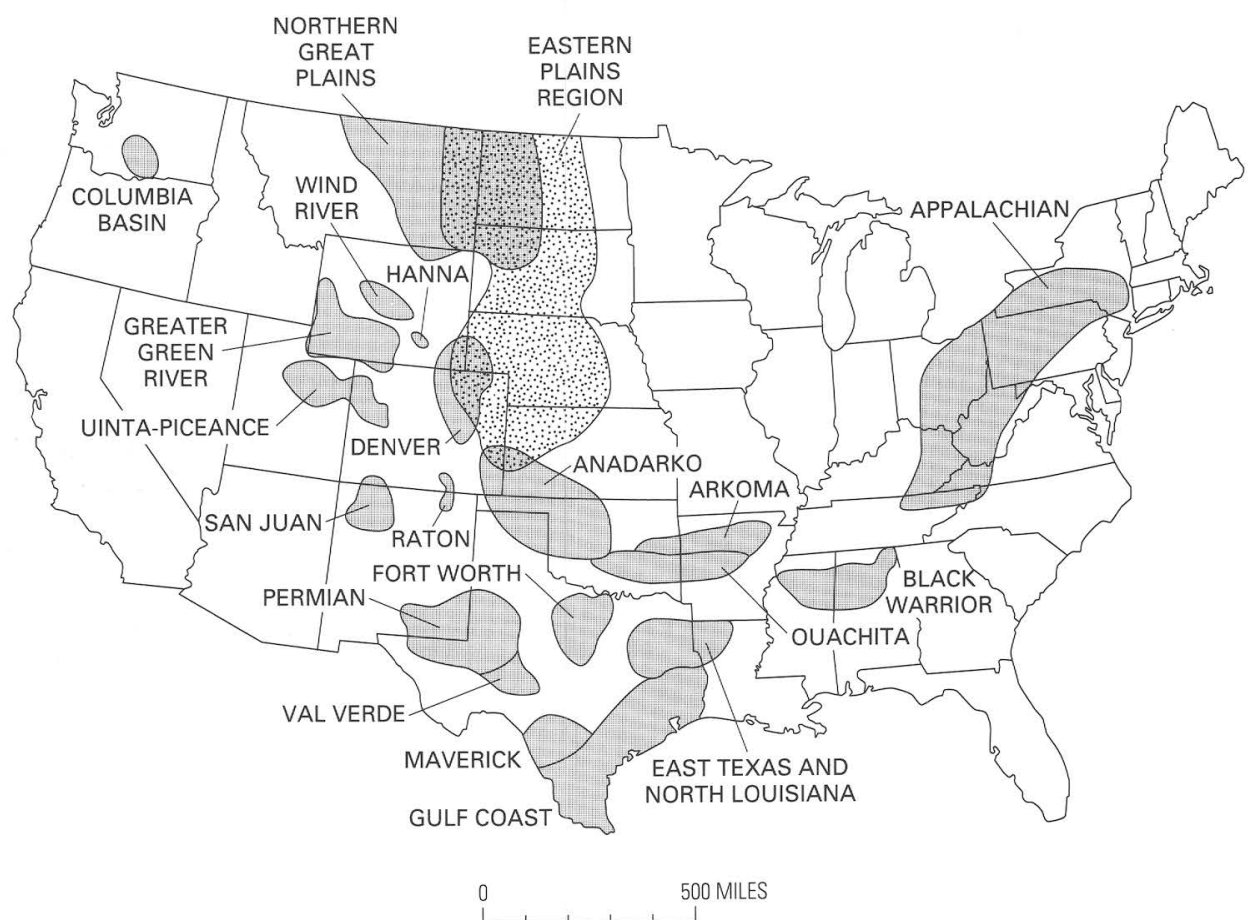

Figure 1 (Law and others). Principal tight gas reservoirs in the United States (patterned). Pattern variation shows overlap of several regions.

States: Gas Research Institute Topical Report, GRI-93/0044, $470 \mathrm{p}$.

Finley, R.J., 1984, Geology and engineering characteristics of selected low-permeability gas sandstones-A national survey: The University of Texas at Austin, Bureau of Economic Geology Report of Investigations $138,220 \mathrm{p}$.

Law, B.E., and Spencer, C.W., 1993, Gas in tight reservoirs-An emerging major source of energy, in Howell, D.G., ed., The future of energy gases: U.S. Geological Survey Professional Paper 1570 , p. 233-252.

Law, B.E., Tennyson, M.E., and Johnson, S.Y., 1994, Basin-centered gas accumulations in the Pacific Northwest-A potentially large overlooked source of energy [abs.]: American Association of Petroleum Geologists 1994 Annual Convention Official Program, v. 3, p. 194.

Masters, J.A., ed., 1984, Elmworth-Case study of a deep basin gas field: American Association of Petroleum Geologists Memoir 38, $316 \mathrm{p}$.

National Petroleum Council, 1992, The potential for natural gas in the United States-Source and supply, Volume II: National Petroleum Council, Committee on Natural Gas, 330 p.

Spencer, C.W., 1989, Review of characteristics of low-permeability gas reservoirs in western United States: American Association of Petroleum Geologists Bulletin, v. 73, no. 5, p. 613-629.

Spencer, C.W., and Mast, R.F., eds., 1986, Geology of tight gas reservoirs: American Association of Petroleum Geologists Studies in Geology 24, 299 p.

\section{Coalbed Methane-From Hazard to Environmental Concern and Untapped Energy Resource}

Dudley D. Rice and Richard B. Wanty,
U.S. Geological Survey, Denver, CO 80225 ; Charles W. Byrer, U.S. Department of Energy, P.O. Box 880, Morgantown, WV 26505; and Dina W. Kruger, U.S. Environmental Protection Agency, 401 M St. S.W., Washington, D.C. 20460

Coal beds have unique characteristics which are different from all other types of rocks from which hydrocarbons are generated and produced. These characteristics are briefly described herein, and presented in more detail in Law and Rice (1993) and Rice and others (1993).

Large amounts of natural gas are generated in coal beds throughout their burial history. The yield is probably in the range of 5-6 MCF/ton (thousand cubic feet per ton). Coalbed gases are variable in their composition. Although methane is generally dominant, significant amounts of heavier hydrocarbon gases, carbon dioxide, and nitrogen can also be present. In addition, hydrogen-rich coal beds can generate and sometimes produce liquid hydrocarbons which are viscous and can cause problems for production. 
Most of the gas in coals is stored on the internal surfaces of the organic matter. Because coal has large internal surface areas, it can store large amounts of gas: coal can hold much more gas than the same rock volume of a conventional reservoir. Gas content generally increases with rank, depth of burial, and reservoir pressure. At higher ranks, coals may even have generated more gas than they can store, resulting in its expulsion into adjacent reservoirs.

Permeability is essentially nonexistent in the matrix of coal, but is developed in the fractures, commonly referred to as cleats. The factors which control the permeability of cleats are their density, connectivity, and aperture width. These factors are, in turn, regulated by bed thickness, coal quality and rank, tectonic deformation, and stress. In general, permeability decreases with increasing depth of burial and is not well developed in areas that have been structurally deformed.

The cleats are generally filled with water. The sources of water are (1) original water from the time that peat was deposited, (2) atmospheric, and (3) adjacent aquifers. In some places, cleats may be filled with gas above the water table.

Coalbed gas production is controlled by several processes, including release of gas from internal surface areas and flow of both gas and water in the cleats. As a consequence, coalbed gas wells have a distinctive production history characterized by (1) early stage when large amounts of water are produced from the cleats to reduce reservoir pressure and initiate release of the gas from the internal surface areas, (2) stable stage when quantities of gas increase as the quantities of water decrease ("negative or reverse decline"), and (3) late stage when the amount of gas declines and water production remains low.

Coalbed methane accumulations are widespread, and in-place gas resources in the United States are estimated to amount to more than $700 \mathrm{TCF}$. However, the economically recoverable resources, which generally occur at depths between 500 and $6,000 \mathrm{ft}$, are probably less than $100 \mathrm{TCF}$. Areas with reserves and (or) potential additions to reserves are shown in figure 1.

Two environmental concerns are related to coalbed methane-methane emissions from mining, as described by Kruger (1994), and water disposal. ${ }^{1}$ Pressure reduction during coal mining, particularly underground, results in the release of coalbed methane. In the United States, coal mines may account for as much as 15-20 percent of the total atmospheric methane emissions associated with human activities. The majority of these mine-related emissions come from the

\footnotetext{
${ }^{1}$ Methane is a potent "greenhouse" gas which has an atmospheric residence time of 8-12 years. Atmospheric concentrations of methane have more than doubled during the past 200-300 years. This increase is interpreted to be the result of human activities, including coal mining. Reductions of methane emissions would have noticeable short-term impacts on atmospheric concentrations.
}

Eastern United States, particularly the Appalachian basin (fig. 1). Most of this gas is presently being emitted to the atmosphere in the mine ventilation air and by the mine degasification systems as a safety precaution. As part of the President's Climate Change Action Plan (October 1993), coal mines are being encouraged to recover and utilize this methane. Such recovery would mitigate the environmental concerns and provide significant economic benefits, including increased employment, additional State revenues, and a return on investments for the coal mines and other companies. However, its development will only result if certain issues are addressed, such as gas ownership, conflicts between activities of coal mining and coalbed methane development, and utilization options.

Water is commonly produced from coalbed gas wells, especially during the early stages of production. The volume of water produced from an individual coalbed gas well is generally much higher than that produced from other types of oil and gas wells. The quantity and quality (total dissolved solids and salinity) of water vary considerably in coal-bearing basins and reflect the water's residence time and rockwater interactions in the subsurface and ground-water flow patterns (Tyler and others, 1991). Water quality and quantity are generally lower in the central, deeper parts of basins compared to the shallower parts of basins that are near recharge areas of relatively fresh atmospheric water.

Environmentally acceptable options of water disposal vary from inexpensive methods, such as surface discharge, to more costly alternatives, such as underground injection or surface discharge after treatment. Another alternative, which has not been employed, is evaporation and collection of solid residues (Wanty and others, 1993). Because coalbed waters are commonly rich in sodium, carbonate, and chloride, the possibility exists that the evaporation products may be trona and halite, both salable commodities. Thus, if sufficient water was produced and evaporation rates are high enough (as in the arid Rocky Mountain area), evaporation may be an environmentally and economically feasible brine-handling method.

\section{REFERENCES}

Kruger, D.W., 1994, The environmental and economic benefits of coalbed methane development in the Appalachian region: U.S. Environmental Protection Agency EPA/430/R-94/007, 30 p.

Law, B.E., and Rice, D.D., eds., 1993, Hydrocarbons from coal: American Association of Petroleum Geologists Studies in Geology 38, 400 p.

Rice, D.D., Law, B.E., and Clayton, J.L., 1993, Coalbed gas-An undeveloped resource, in Howell, D.G., ed., The future of energy gases: U.S. Geological Survey Professional Paper 1570, p. 389-404.

Tyler, R., Ambrose, W.A., Scott, A.R., and Kaiser, W.R., 1991, Coalbed methane potential of the Greater Green River, 


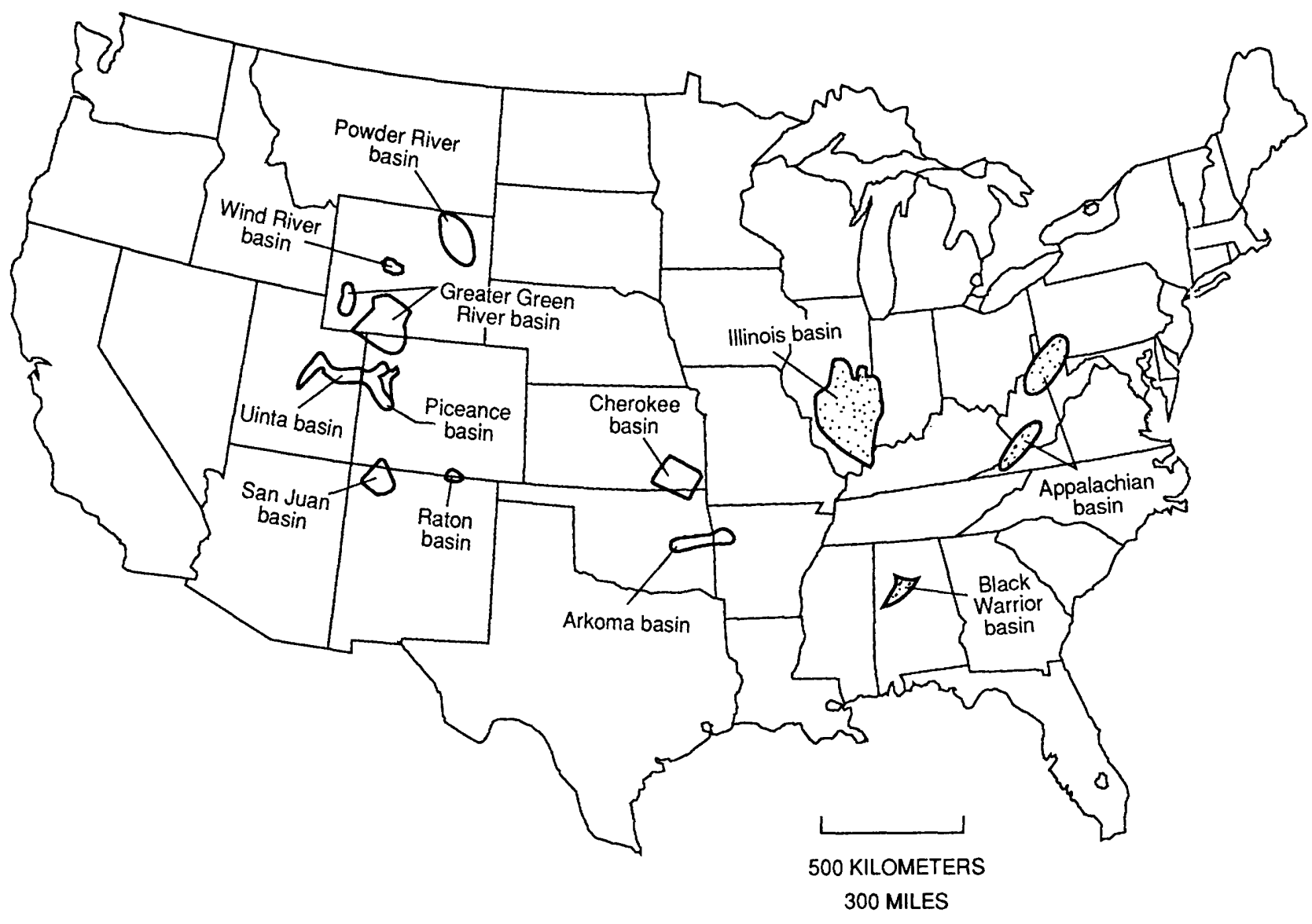

Figure 1 (Rice and others). Map of United States showing areas with reserves and (or) potential additions to reserves of coalbed methane. These resources generally extend from depths of 500 to $6,000 \mathrm{ft}$. Stippled areas have potential for recovery in assiociation with underground coal mining.

Piceance, Powder River, and Raton basins: Gas Research Institute Topical Report GRI-91/0315, 224 p.

Wanty, R.B., Folger, P.F., and Briggs, P.H., 1993, Ground-water chemistry of the coal-bearing Upper Cretaceous Mesaverde
Formation, Wind River Reservation, Wyoming, in Keefer, W.R., Metzger, W.J., and Godwin, L.H., ed -. Oil and gas and other resources of the Wind River basin, Wroming: Wyoming. Geological Association Special Symposium p. 271-279. 


\section{Availability and Quality of Energy Resources \\ World Energy}

International Coal-Related Activities of the U.S. Geological Survey and Their
Environmental Applications

\author{
John R. SanFilipo and Peter D. Warwick, \\ U.S. Geological Survey, Reston, VA 22092
}

Most of the underdeveloped and developing nations of the world face severe shortages of energy, and many industrialized nations that are in transition from centrally planned to market economies face collapsing energy distribution networks. These energy-poor nations are among the most environmentally stressed. This fact is due in part to the direct effects of primitive energy technologies and the low quality of available fuels, but it is also a consequence of the poverty and lack of social and technological infrastructure that invariably attend energy deficits. For such nations, the orderly development of underutilized indigenous coal resources and the upgrading of existing coal technologies can lead to economically viable sources of energy that are relatively benign from an environmental standpoint, and can contribute to long-term political stability as well.

Working closely with representatives of counterpart agencies in the host countries, the U.S. Geological Survey has conducted commodity-related coal studies in a variety of such international settings (fig. 1), generally with the sponsorship of international donor or lending agencies such as the U.S. Agency for International Development or the Asian Development Bank (table 1). These studies have focused on coal resource assessments in nations with acute energy shortages and on coal quality studies in areas where development has had recognizable environmental impacts. Many of these studies have been conducted in areas of particular strategic interest to the United States, and technology transfer to ensure the sustainable ability of the host country to integrate geosciences into decision-making is an integral part of most programs.

Because of a dependence on scavenged fuel (firewood, animal dung, and crop residue) for everyday energy needs, half the world's population faces chronic poverty, ill health, and severe pressure on local ecosystems. In addition to the direct environmental effects of such local practices as deforestation, scavenged fuels are inefficient and emit more greenhouse gases than other fuels. Transition to commercial fuel economies for these people is both inevitable and desirable. Poor nations that have begun this transition face additional environmental pressures from the forces of urbanization in the face of insufficient energy available to support adequate water, transportation, and refrigeration systems. The USGS cooperative international coal resource assessments-which include evaluation of the quant ty, distribution, and quality of coal from existing information or new exploration-are meant to address these probl sms by identifying potential new sources of energy. Results of some of the more comprehensive studies include (1) increasing the known coal resources of Pakistan from 800 million to more than 80 billion $t$ (metric tons) of coal suitable for com 'nercial power generation or briquetting; (2) a thorough compilation of the coal resources of Latin America, which has res utted in state-of-the-art coal maps covering the entire region, a comprehensive coal resource assessment for much of Cos ta Rica, and a preliminary utilization feasibility study for Haiti; (3) the first systematic sampling and analysis of newly discovered thick Permian coals on the Rangpur Saddle of Bangladesh; and (4) a comprehensive geologic analysis of the Ordos coal basin of north-central People's Republic of China. Additional pilot studies have been condu ted in Armenia, India, Kyrgyzstan, the Philippines, northern Africa, and the western Pacific rim.

Coal development in many areas of the world has historically been unencumbered by environmental ccncerns. This situation has been particularly acute in some heavily industrialized areas of low-quality coals in Eastern Europe. The collapse of energy subsidies and the consequent decline in industrial output in these and other areas in transition to market economies have resulted in continuing pressure to utilize indigenous resources regardless of their intrinsic quality characteristics. The cooperative international coal quality studies of the USGS have focused on identif.'ing the origins, modes of occurrence, and behavior of coal-derived pollutants in such areas. Results of recent studies inc'ude (1) identification of the probable cause of a widespread disease in southeastern Europe (Balkan endemic nephropathy) as inplace leaching of toxic and carcinogenic organic compounds from lignite beds, and (2) identification of the sources for several potentially toxic elements associated with coals in (the former) Yugoslavia and other areas of Eastern Europe, along with possible mitigating technologies for their recovery as ash byproducts.

In addition to commodity-related studies, USGS coal researchers have participated in a number of topical research projects in international areas of particular scientific interest. Some of these studies utilize unique foreign settings to develop geologic models that can help pretict the occurrence and quality of coal and other fossil fuels: others use the unique nature of coal and associated rocks as paleoenvironmental indicators to enhance our knowledge of global environmental processes such as climate. Recent areas of study include (1) Indonesian equatorial peat swamps as 


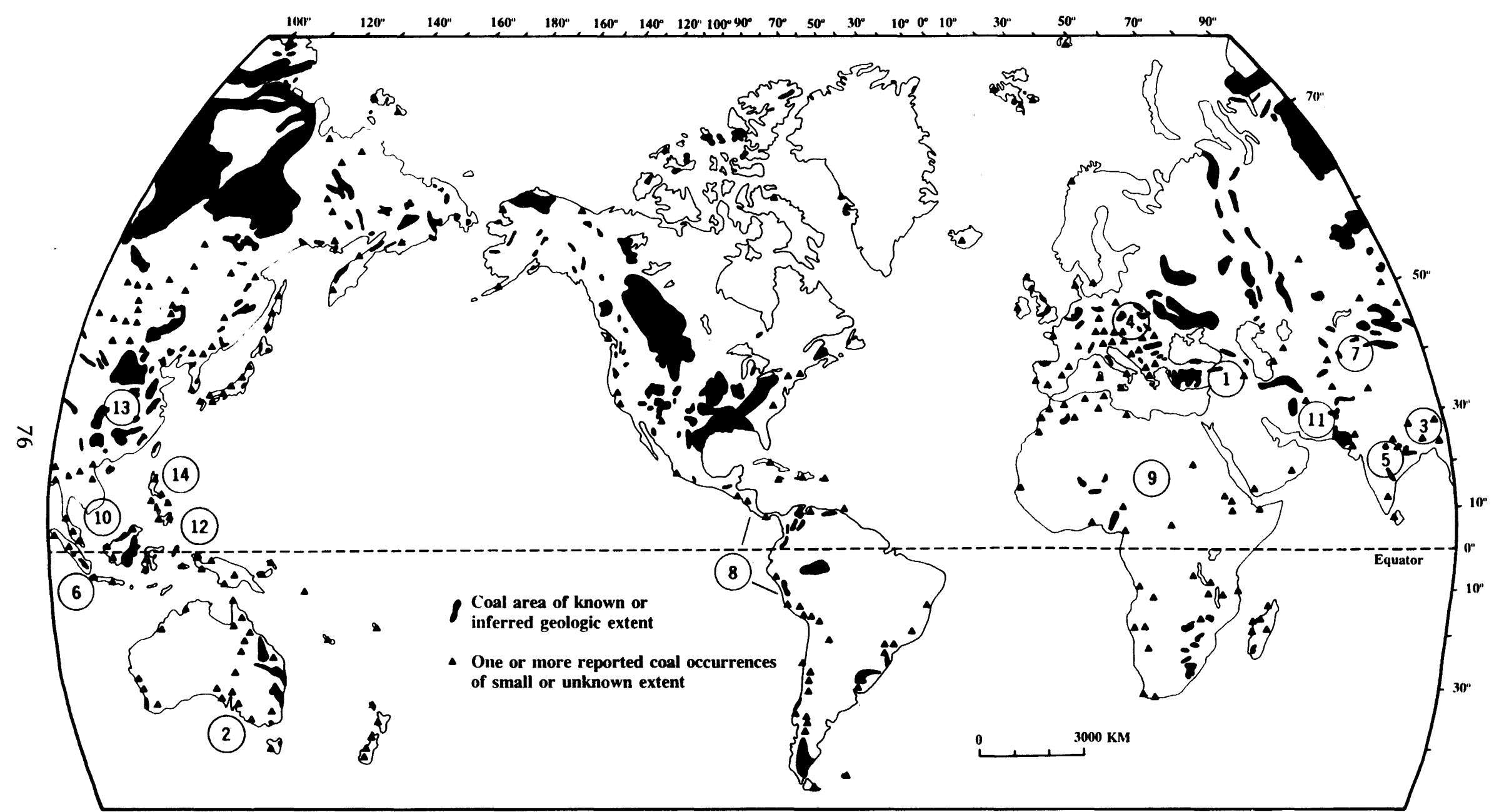

Figure 1 (SanFilipo and Warwick). Global coal distribution (Antarctica not shown). Modified from Landis and Weaver, 1993. Refer to table 1 for numbered USGS project areas. 
Table 1 (SanFilipo and Warwick). Selected coal-related international projects of the U.S. Geological Survey.

[USAID, U.S. Agency for International Development; ADB, Asian Development Bank; S\&T, U.S. State Department Science and Technology Fund]

\begin{tabular}{|c|c|c|c|c|}
\hline \multicolumn{2}{|c|}{ Area } & \multirow{2}{*}{$\begin{array}{c}\text { Dates } \\
1993-1997\end{array}$} & \multirow{2}{*}{$\frac{\text { Types }}{\text { Resource assessment }}$} & \multirow{2}{*}{$\begin{array}{l}\text { Main sponsor; collaborators } \\
\text { USAID; Armenian Dept. Underground } \\
\text { Resources. }\end{array}$} \\
\hline 1. & Armenia & & & \\
\hline 2. & Australia & 1994 & Coorong wetlands & University of Adelaide. \\
\hline 3. & Bangladesh & $1989-1990$ & Resource assessment & ADB; Geological Survey Bangladesh. \\
\hline 4. & Eastern Europe & $1987-1996$ & Coal quality; methane & $\begin{array}{l}\text { S\&T; various European government and } \\
\text { academic institutions. }\end{array}$ \\
\hline 5. & India & 1994 & Resource assessment & S\&T; Geological Survey India. \\
\hline 6. & Indonesia & $1987-1989$ & Modern coal analogs & Indonesian Directorate of Mineral Resources. \\
\hline 7. & Kyrgyzstan & $1993-1994$ & Resource assessment & $\begin{array}{l}\text { USAID; Ministry Industry, Material } \\
\text { Resources, \& Trade. }\end{array}$ \\
\hline 8. & Latin America & 1983-1993 & Resource assessment & USAID (Costa Rica); various foreign agencies. \\
\hline 9. & North Africa & $1986-1990$ & Resource assessment & $\begin{array}{l}\text { Fed. Inst. for Geosciences and Energy } \\
\text { (Germany). }\end{array}$ \\
\hline 10. & Pacific basin & 1992 & Resource assessment & $\begin{array}{l}\text { Circum-Pacific Council for Energy \& Mineral } \\
\text { Resources. }\end{array}$ \\
\hline 11. & Pakistan & $1985-1993$ & Resource assessment & USAID; Geological Survey of Pakistan. \\
\hline 12. & Palau & $1987-1996$ & Origins organic sulfur & American Chem. Soc., Florida State Univ. \\
\hline 13. & PR China & $1982-1990$ & Resource assessment & S\&T; Ministry of Coal Industry. \\
\hline 14. & Philippines & $1984-1985$ & Resource assessment & $\begin{array}{l}\text { USAID; Philippine Bureau of Economic } \\
\text { Development. }\end{array}$ \\
\hline
\end{tabular}

modern analogs to climate-dependent coal-forming processes, and (2) identification of the bacterial origins for modern non-point-source pollution in the Coorong wetlands of Australia, and recognition of these bacterial processes as possible analogs for the occurrence of trace elements in coal.

\section{SELECTED REFERENCES}

Bostick, N.H., Betterhorn, W.J., Gluskoter, H.J., and Islam, M.N., 1991, Petrography of Permian "Gondwana" coals from boreholes in northwestern Bangladesh, based on semiautomated reflectance scanning: Organic Geochemistry, v. 17, no. 4, p. 399-413.

Cecil, C.B., Dulong, F.T., Cobb, J.C., and Supardi, 1993, Allogenic and autogenic controls on sedimentation in the central Sumatra basin as an analogue for Pennsylvanian coal-bearing strata in the Appalachian basin: Geological Society of America Special Paper 286, p. 3-22.

Feder, G.L., Radovanic, Z., and Finkelman, R.B., 1991, Relationship between weathered coal deposits and the etiology of
Balkan endemic nephropathy: Kidney International, v. 40, suppl. 34, p. 9-11.

Landis, E.R., and Weaver, J.N., 1993, Global coal occurronce, in Law, B.E., and Rice, D.D., Hydrocarbons from coal: American Association of Petroleum Geologists Studies in Geolngy 38, p. $1-12$.

Ruppert, L., Finkelman, R.B., Boti, E., Milosavljevic, M., Tewalt, S., Simon, N., and Dulong, F., in press, Origin and sign: ficance of high nickel and chromium concentrations in Pliocene lignite of the Kosovo Basin, Serbia and Montenegro: International Journal of Coal Geology.

SanFilipo, J.R., and Khan, R.A., 1994, The "discovery" of a blind coal field in the Thar Desert of Pakistan, with the help of some unconventional techniques, in Chiang, A.H., ed., Coal-Energy and the Environment: Proceedings of the Eleventh Annual Pittsburgh Coal Conference, Sept. 12-16, 1994; University of Pittsburgh Center for Energy Research.

Weaver, J.N., and Landis, E.R., 1990, Coal and peat in the subSaharan region of Africa: Natural Resources Forum, v. 14, no. 1, p. 64-69.

Weaver, J.N., and Wood, G.H., Jr., 1994, Coal map of Soutl America: U.S. Geological Survey Coal Investigations Map C-145, scale $1: 7,500,000$. 


\section{Environmental Effects of Natural Energy Occurrence}

\section{Atmospheric Methane Flux From Coals}

\author{
J.L. Clayton, J.S. Leventhal, and D.D. Rice, \\ U.S. Geological Survey, Denver, CO 80225
}

Methane is an important greenhouse gas whose atmospheric concentration is increasing. The increase in atmospheric methane is correlative with growth in human population and activities, although the exact causes of the increase are not known. Although methane leaking from fossil fuels is estimated to account for a significant proportion of the total annual flux of methane into the atmosphere, considerable uncertainty exists with respect to the precise amount. Recent studies indicate that coal mining, natural gas ventilation, and gas transmission losses may constitute approximately $50-114 \mathrm{Tg}$ of methane (teragrams, $10^{12} \mathrm{~g}$ ) out of a total annual global flux from all sources estimated at $540 \mathrm{Tg}$ (Khalil and Rasmussen, 1985; Stevens and Englekemeir, 1988; Cicerone and Oremland, 1988; Hogan and others, 1991). However, the estimates for fossil fuel fluxes are rough, because very limited data are available for methane flux associated with exploitation of fossil fuels, and only one study has reported data on methane release through natural processes affecting fossil fuels (Clayton and others, 1993).

Coal production worldwide is likely to increase over the next few decades because of increasing energy demand, particularly in developing countries, such as People's Republic of China, where population and economies are growing. Increased coal utilization to help fulfill energy demand could lead to increased flux of methane to the atmosphere. In order to develop optimal governmental policies for remediation of methane emissions from coal and to better understand the global methane cycle, scientists, and especially planners and regulators need more accurate assessments of methane release from coal beds. Quantitative data are needed not only for methane release associated with mining activities, but also for natural processes such as leakage along faults or from outcrops. Moreover, improved understanding of the relative importance of the various factors (for example, age of the coal, thermal maturity, geologic setting, hydrogeology) that influence emission rate is essential if limited quantitative data are to be extrapolated to global estimates of the importance of coal beds as sources of atmospheric methane.

The objective of the present study is to provide quantitative data on methane flux between coal beds and the atmosphere caused both by human activities and by natural processes. Sampling sites were selected in the Black Warrior Basin, Alabama (Pennsylvanian age coal); the Powder River Basin, Wyoming (Tertiary age coals); the San Juan Basin, Colorado and New Mexico (Cretaceous age coals); and coal basins in Poland (Miocene and Pennsylvania" age coals) and the Czech Republic (Pennsylvanian age coals). The sites were chosen to evaluate the effects of several variables on the methane flux-local geology, coal rank, coal geochemistry, burial depth of the coal, thermal histor: mining methods, age of the mine or exposure, and local hydrogeology. The purpose of this approach is to provide data that allow improved quantification of methane flux in specific study areas and to assess the importance of various controlling factors that influence the flux.

Ventilation to improve safety during underground mining is the largest single source of atmosnheric methane from coals, although some faults and fractires associated with tectonic development of some coal basins serve as significant migration conduits for coalbed me'hane emissions from natural degassing of coals. For exam r'e, in the Black Warrior Basin, Alabama, as much as $136,070 \mathrm{~L}(97,144 \mathrm{~g})$ of methane per minute is released from one ventilation shaft from underground mining. In additior. methane from coals at present-day burial depths of abort 2,000 feet or greater was identified leaking along fault zcnes in rock outcrops, although in much smaller quantities $[1 \mathrm{~L} / \mathrm{min}(0.71$ g) at a point source along a fault zone] com?ared to ventilation of underground mines. Similarly, ir the San Juan Basin, methane was observed leaking from surface features thought to be associated with high-angle faults that serve as migration conduits between coal beds and the atmosphere. However, unlike the Black Warrior Basin, fault traces were not observed in surface outcrops, but were only inferred from surface topography and the high methane flux.

In contrast, surface mines studied to 1994 release relatively smaller quantities of methane than ventilation shafts and, in some cases, less than naturally occurring faults. A significant finding is that methane flux from surface mines exhibits significant variability, both between mines containing similar types of coal and at different locations within a single mine. The amount of methene released during surface mining is highly sensitive to th? tectonic development and thermal history of the basin, as well as time (age of the mine). For example, in the Blac'- Warrior Basin, Pennsylvanian coals reached maximum thermal maturation (burial) by late Paleozoic to early Mesozoic time. Uplift occurred at about the same time, allowing loss of most of the methane in near-surface coals over geologic time. Methane flux measurements were made at several surface mines of Tertiary coal in the Powder Rirer Basin, Wyoming. Here, methane flux was quite variak ${ }^{\prime e}$ depending on local conditions and length of time that th ? coal had been exposed. For example, some freshly uncovered coals had significant methane release, whereas coal benches that had been exposed for long periods of time (as long as several 
years) had very low fluxes. For comparison, brown coal (lignite) was studied at two large surface mines in Poland (Belchatow and Turow). In these mines, the methane release rate is highly variable and is apparently controlled by local geology and hydrogeology.

\section{REFERENCES}

Clayton, J.L., Leventhal, J.S., Rice, D.D., Pashin, J.C., Mosher, B., and Czepiel, P., 1993, Atmospheric methane flux from coals-Preliminary investigation of coal mines and geologic structures in the Black Warrior Basin, Alabama, in Howell, D.G., ed., The future of energy gases: U.S. Geological Survey Professional Paper 1570, p. 471-492.

Cicerone, R.J., and Oremland, R.S., 1988, Biogeochemical aspects of atmospheric methane: Global Biogeochemical Cycles, v. 2, p. 299-327.

Hogan, K.B., Hoffman, J.S., and Thompson, A.M., 1991, Methane on the greenhouse agenda: Nature, v. 354, p. 181-182.

Khalil, M.A.K., Rasmussen, R.A., Shearer, M.J., Ge, S., and Rau, J.A., 1993, Methane from coal burning: Chemosphere, v. 26, p. 473-477.

Stevens, C.M., and Englekemeir, A., 1988, Stable carbon isotopic composition of methane from some natural and anthropogenic sources: Journal of Geophysical Research, v. 93, p. 725-733.

\section{Is Increasing Atmospheric $\mathrm{CO}_{2}$ Really a Harbinger of Global Warming- A Perspective Through Geologic Time}

\author{
Charles W. Holmes, U.S. Geological Survey, \\ Denver, CO 80225
}

The specter of global warming, which is perceived to be the result of increasing "greenhouse" gases (mainly $\mathrm{CO}_{2}$ ) in the atmosphere, has prompted a reexamination of the carbon cycle and plant/atmosphere interaction during the past 350 million years. Many believe that, at present, the ocean is a major reservoir or "sink" of carbon, absorbing up to a third of the emissions arising from present-day fossil-fuel use and deforestation. The remaining carbon is assumed to remain in the atmosphere. However, when the carbon concentration in the ocean plus the carbon in the atmosphere are compared to the amount released from human activities, the accounting sheet does not balance. This missing "sink" may be found in the "activity" of land plants.

One approach in developing an understanding of the modern carbon cycle is to examine variations in the carbon cycle that have occurred in the geologic past. Whereas measurement of carbon concentrations of ancient atmospheres is impossible, the distribution of isotopes of carbon in material formed from atmospheric carbon has been found to be a useful proxy. Carbon has two stable isotopes, carbon- $13\left({ }^{13} \mathrm{C}\right)$ and carbon-12 $\left({ }^{12} \mathrm{C}\right)$. The ratio of these isotopes in carbon based material is controlled by established thermodynamic laws. For example, during weathering of organic material, the oxidation process produces a solid residual and a gas $\left(\mathrm{CO}_{2}\right)$. As the "fixed" carbon is oxidized to a gas, the heavier carbon ${ }^{13} \mathrm{C}$ lags with the residual material. and the lighter ${ }^{12} \mathrm{C}$ concentrates in the gas. The result is that the residue becomes isotopically "heavier" and the gas becomes "lighter."

Most carbon sequestered in land and ocean sed 'ments is "fixed" by the activity of plants. Photosynthesis, the process by which plants "fix" carbon, controls the isotopic ratio in plants. Carbon fixation is a fundamentally simple process. $\mathrm{CO}_{2}$ enters the leaf through a pore called a stoma, ar $d$ moves into a cell where it is fixed by an enzyme. Some of this product reacts with oxygen during photorespiration, releasing some $\mathrm{CO}_{2}$ back to the atmosphere. This process prefers to "fix" the lighter isotope $\left({ }^{12} \mathrm{C}\right)$, so that the plant is iso'>pically lighter than the atmospheric carbon source.

In studying the photosynthetic process, Farquhar and others (1982) found that the ${ }^{13} \mathrm{C}:{ }^{12} \mathrm{C}$ ratio in plants is a function of two factors: (1) the ratio of the $\mathrm{CO}_{2}$ concentration in the atmosphere surrounding the plant to the concentration of $\mathrm{CO}_{2}$ within the plant cell, and (2) the isotopic ratio of the $\mathrm{CO}_{2}$ source (fig. 1). Other studies have shown th't as the $\mathrm{CO}_{2}$ concentration of the atmosphere rises, the isotcnic ratio becomes lighter (Polley and others, 1993; Van de W'ater and others, 1994). If "the present is the key to the part," then ancient $\mathrm{CO}_{2}$ atmospheric concentrations can be estimated from isotopic measurements on plant material form $₫ d$ from atmospheric carbon.

As the carbon fixed by marine plants in the surface layers of the ocean is assumed to be in equilibrium with the atmosphere, the isotopic ratio of various-aged sediments produced by plants has been used to estimate the $\mathrm{C}_{2}$ concentrations of ancient atmospheres. However, examination of the products of ocean plants shows no simple relationship between the carbon in the ocean plants and t $s$ atmosphere. Commonly, an influx of excess food (nutrients) will cause marine plants to grow very rapidly. WJan this occurs, the plants "reach" for all the carbon that they can get. Because the movement of $\mathrm{CO}_{2}$ in the water is slow, $\mathrm{CO}_{2}$ does not reach isotopic equilibrium with new' carbon from the atmosphere. As a result the plants will rearsimilate the heavy respirated carbon, yielding a sediment rich in organic matter with a heavier, non-equilibrium isotopic ratio. Plants living near mouths of major rivers vill also produce a non-equilibrium isotopic ratio. At the se sites, atmospheric carbon is mixed with land-derived carton, producing a carbon source isotopically lighter than the equilibrium carbon.

Until recently very little attention has been paid to the isotopic composition of modern or ancient carbon deposits of land plants: peat and coal. Coals form in several different types of environments, including lcw-lying mires such as the Okefenokee Swamp, Georcia, and 


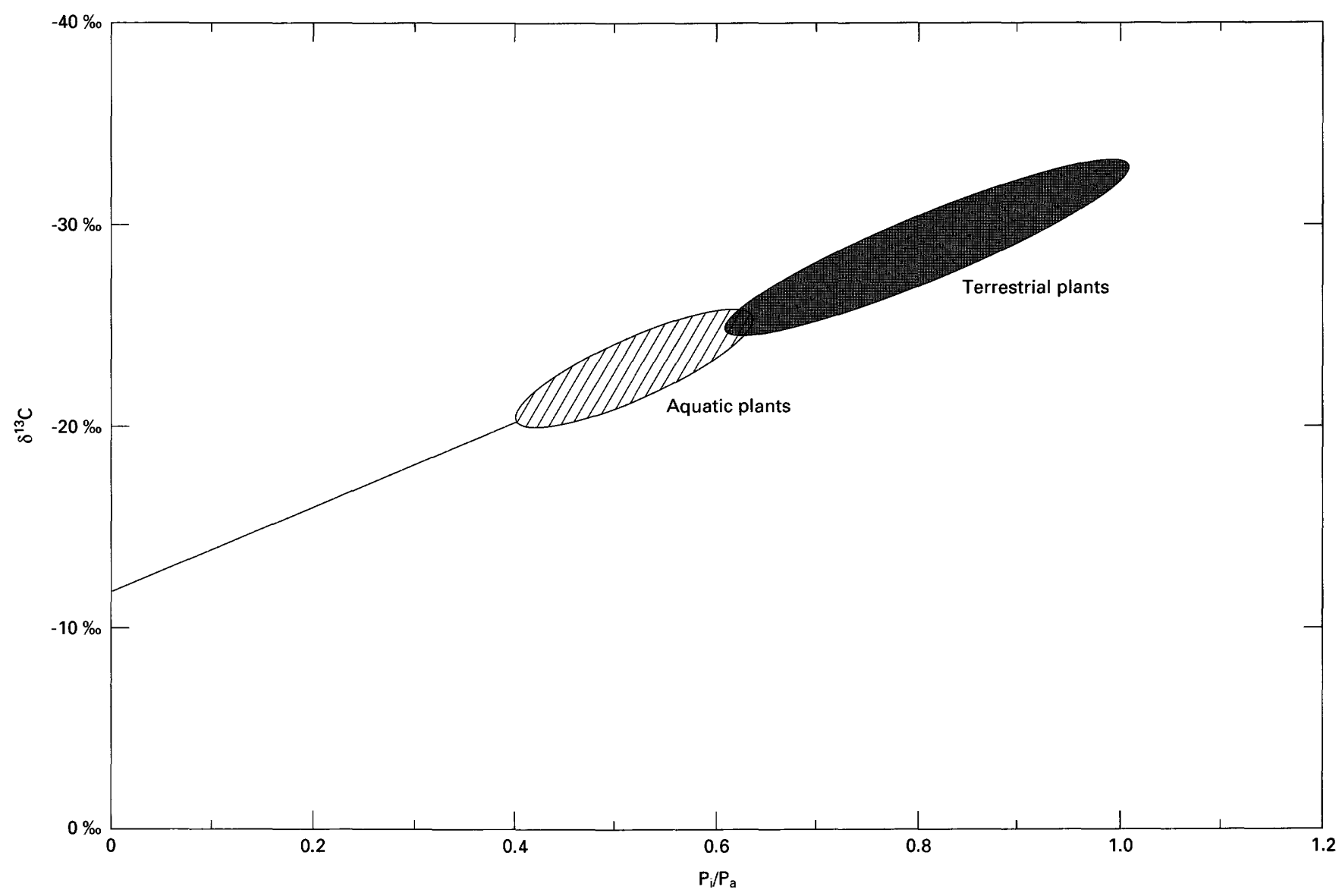

Figure 1 (Holmes). Carbon isotopic ratio of plants (vertical scale) versus the ratio (horizontal scale) of the $\mathrm{CO}_{2}$ concen+ration within the plant cell $\left(\mathrm{P}_{\mathrm{j}}\right)$ to $\mathrm{CO}_{2}$ concentration in the air $\left(\mathrm{P}_{\mathrm{a}}\right)$. The slope of the line is $(-7.0 \%)$, the present carbon isotopic ratio of the atmosphere. The $\delta^{13} \mathrm{C}$ notation is a standard notation used by scientists in which all analyses are compared to a standard. In this notation the more negative the value, the "lighter" or the more ${ }^{12} \mathrm{C}$ isotope is in the sample.

raised mires such as the tropical rain-forests of Indonesia. Like oceanic plants, the plants growing in lowlying mires have many sources of carbon. In addition, many of the plants are aquatic and have different carbon ratios than terrestrial plants (fig. 1). In raised mires, however, only one source of carbon exists-the atmosphere. Thus if terrestrial plant deposits of peat and coal remain chemically unaltered with respect to isotopic composition through geologic time (and no evidence has been found of such alteration), any changes in the atmospheric carbon isotopic ratio, and by extension atmospheric $\mathrm{CO}_{2}$ concentration, are recorded.

Carbon isotopic ratios from $>400$ raised mire coal and peat samples ranging from $\mathbf{3 5 0}$ million years old to modern show a steady change in isotopic composition (fig. 2). The older coal samples are enriched in ${ }^{13} \mathrm{C}$ with respect to the modern coals and peats. The trend apparent in these data is confirmed in the isotopic ratios of carbonized plant remains (Taylor and Hickey, 1991). Because individual coal-forming environments exist for a short time geologically $(\approx 1,000$ to $\approx 5,000$ years), the isotopic ratios determined from these deposits are integrated over this time span. The spread, as presented in figure 2, may represent short-term atmospheric isotopic changes on this time scale.

Applying the Farquhar model to the coal data, 350 million years ago the isotopic ratio averaged $\approx 0.6$ percent heavier than today. From that time to the present, the average ${ }^{13} \mathrm{C}:{ }^{12} \mathrm{C}$ isotopic ratio increased, with greatest rate of change occurring approximately 100 mill:on years ago. These data suggest that the average atmosphere $\mathrm{CO}_{2}$ concentration was very low $\approx 350$ million years ago and slowly increased over geologic time. Climate models based on other geologic data have suggested that the Farth has undergone many shifts from "icehouse" to "greent ouse" and back during this time. The average $\mathrm{CO}_{2}$ concentrotions, however, do not seem to reflect these changes and scigest that $\mathrm{CO}_{2}$ has played only a minor role if any in climate warming or cooling. However, the data seem to fit very well with the increasing diversity of plants, which changed approximately 100 million years ago from a gymnosperm- (such as pine) dominated vegetation to an angiosperm- (such as oak) dominated vegetation. This increase in plant diversity, which filled every environmental niche, seems tc be temporally related to the observed change of $\mathrm{CO}_{2}$ concentration in the 


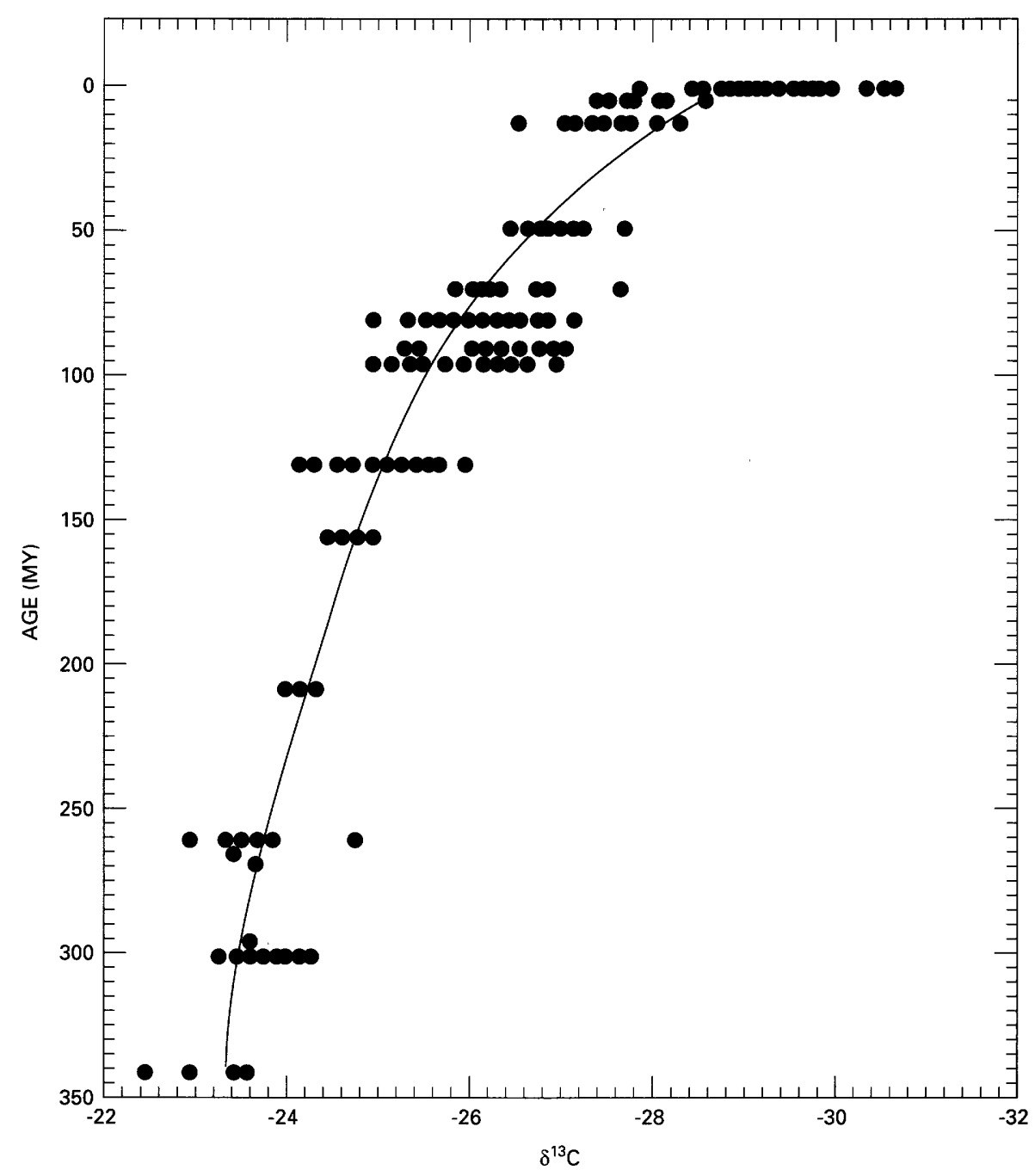

Figure 2 (Holmes). The carbon isotopic ratio of raised mire coal and peat for the last 350 million years.

ancient atmosphere. This suggests that plants have played a major role in buffering the $\mathrm{CO}_{2}$ concentration of the atmosphere.

\section{REFERENCES}

Farquhar, G.P., O'Leary, M.H., and Berry, J.A., 1982, On the relationship between carbon isotopes discrimination and the intercellular carbon dioxide concentrations in leaves: Australian Journal of Plant Physiology, v. 9, p. 121-137.

Polley, H.W., Johnson, H.B., Marine, B.D., and Mayeux, H.S., 1993, Increase in $C_{3}$ plant water-use efficiency and biomass over Glacial to present $\mathrm{CO}_{2}$ concentrations: Nature, v. 361, p. $61-64$.

Taylor, D.W., and Hickey, L.J., 1991, Carbon isotope ratios in fossil land plants: American Journal of Botany, v. 78, p. 126-127.

Van de Water, P.K., Leavitt, S.W., and Betancourt, J.L., 1994, Trends in stomatal density and ${ }^{13} \mathrm{C} /{ }^{12} \mathrm{C}$ ratios on pinus flexilis needles during last glacial-interglacial cycle: Science, v. 264, p. 239-243.

\section{Methane Budget and Global Change in Coastal Wetlands}

\author{
Joel Leventhal, U.S. Geological Survey, \\ Denver, CO 80225
}

Atmospheric methane is a greenhouse gas that $h \boldsymbol{c}^{\mathrm{s}}$ been of increasing importance during the last few decades. Prior to this century, the sources of atmospheric methane were mainly wetlands. However, in the last 100 years the sources have changed: many wetlands have been lost, and rice paddies, cattle raising, energy-related activities, and biomass burning are now much more important relative to wetlands (Cicerone and Oremland, 1988). At this point, we have probably perturbed the system about as much as pcssible, and emission increases in these new methane sources will level off or actually decrease in the future. Most of these 
methane-producing activities are only known to a factor of two; because there are more than one or two major sources, the resulting total methane source function is probably only known to a factor of four. Therefore, we need to acquire more and better measurements of major (and minor) methane sources. It is also particularly important to assemble more information about the relative changes and rate of changes possible or expected from these sources. One methane source we are studying is coastal wetlands.

Global warming will cause a rise in sea level that will result in conversion of fresh-water coastal wetlands to brackish or sea-water-salinity. For the United States, a 50 percent loss of coastal fresh-water marshes is projected to occur for a 1-meter rise in sea level (Park and others, 1989). Estuarine wetlands are presently an important contributor to the global methane flux because of the high primary productivity and the rapid turn-over of organic matter. Bacterial sulfate reduction is energetically favored (it always precedes bacterial methane production); therefore, in sulfate-rich marine settings, methane production is much less than in fresh-water environments. This results in negative feedback: methane production and emission will decrease due to sea-level rise (Leventhal, 1991). Methane production will decrease because the fresh-water marshes are restricted from migrating up-gradient due to human-constructed physical barriers such as waterways and levees. Before 1900, U.S. Gulf Coast marsh wetlands accounted for approximately 1 percent of the annual global methane flux. Extrapolating similar marsh areas and methane production to the world gives a 2 to 3 percent decrease in present total global methane flux due to loss of such wetlands as a result of sea-level rise. The estimated range of methane decrease is uncertain because of the inexactly known areal extent of and methane escape from these coastal wetlands worldwide.

Because of the rapid (annual) turn-over of organic matter in wetlands and the short lifetime of methane in the atmosphere (relative to other greenhouse gases), the effect of estuarine wetland inundation is considered "fast" feedback. Loss of coastal wetlands has been occurring during the last 90 years (inland wetlands have also been lost during the last 200 years) and the resulting methane decrease needs to be considered in contemporary-historic methane budgets, which have factored-in only increases in atmospheric methane from rice paddies and cattle. More detailed "ground truth" on the geochemical controls on methane production and emissions from marshes is also needed to quantify the changes in methane flux due to wetland changes and losses.

New results confirm earlier measurements that salt marshes emit less methane than brackish, intermediate, or fresh marshes and thus there is a negative feedback in methane emission due to sea-level rise (Leventhal and others, 1993). However, two new important points have emerged from this work: (1) the salt marsh actually emits more methane than previously thought because at depth, when sulfate is depleted, abundant organic matter remains and is available for methane production, and (2) much of the methane emission in all marsh types is by bubbling (ebullition) during the summer when the porewater is saturated with methane. These two findings give more importance to wetlands as methane sources because most workers have not considered the ebullition contribution; further, they ind " ate a need for revisions in the atmospheric methane budge..

\section{REFERENCES}

Cicerone, R., and Oremland, R., 1988, Biogeoch smical aspects of atmospheric methane: Global Geochemic 1 Cycles, v. 2, p. 299-327.

Leventhal, J., 1991, Global change-Negative feedback between sea level rise and methane production from estuarine wetlands: Eos, v. 72, p. 109.

Leventhal, J., Jackson, L., Smith, K.S., Walton-L ay, K., Balistrieri, L., Foote, A.L., and Gunterspergen, G., 1993, Biogeochemistry along an estuarine salinity gradient-A proxy for sea level rise due to global warming, in Landin, M.C., e-1., Wetlands Proceedings of the 13th annual conference, Society of Wetland Scientists, New Orleans, June 1992, SWS Scrth Central Chapter, Utica, Mississippi: p. 95-100.

Park, R.A., Trehan, M., Mausel, P., and Howe, R., 1989, Coastal wetlands in the 21 st century-Profound alteration due to rising sea level, in Fisk, D., ed., Wetlands-Concerns and successes: American Water Resources Association, SeFł. 1989, p. 71-80.

\section{South Florida Ecosystems Studies-Geochemical History of Ecosystem Conditions and Variability}

\author{
E.C. Spiker, ${ }^{1}$ A.L. Bates, ${ }^{1}$ L.P. Gough, ${ }^{2}$ \\ J.R. Herring, ${ }^{2}$ C.W. Holmes, ${ }^{2}$ R.K. Kotra, ${ }^{1}$ \\ H.E. Lerch, ${ }^{1}$ W.H. Orem, ${ }^{1}$ and \\ V.C. Weintraub, ${ }^{1}$ U.S. Geological Survey \\ (1) Reston, VA 22092; (2) Denver, CO 80225
}

The Everglades, South Florida's extensive freshwater wetland, and Florida Bay are vast natural resources. This complex ecosystem encompasses not only a large ( 2.3 billion $\mathrm{m}^{3}$ ) managed surface water reservoir (Light and Dineen, 1994), but also marine and freshwater fisheries, and the habitats of large populations of wading birds, migratory water fowl, and several threatened and endangere 1 species. It also hosts a number of parks and preserves, including the Everglades National Park, the Big Cypress Prese-ve, and the Loxahatchee Wildlife Refuge. This ecosystem is changing rapidly and may be on the verge of collapse, as a result of nearby urbanization, agricultural activity, and nearly a century of water management. This crisis has led to heightened public concern and recent court rulings mandating restoration of the Everglades and Florida Bay. 
Any restoration effort requires critical management decisions that will be costly and will have a far-reaching impact on the agriculture, urban, and recreation communities of the region, as well as on the natural ecosystem. Clearly, a much better understanding of the hydrology, ecology, and biogeochemistry of this complex Florida system is needed. Under the auspices of the U.S. Geological Survey programs for National Geologic Mapping and Critical Ecosystems Research and Assessment, biogeochemical studies of the region's soils and sediments and their relationship to water chemistry have begun. This research is coordinated with other studies to characterize water quality and ecosystem history by the U.S. Geological Survey, South Florida Water Management District, Environmental Protection Agency, U.S. Department of Agriculture, National Park Service, National Biological Survey, and U.S. Fish and Wildlife Service, all part of the Federal Task Force on Everglades Ecosystem Restoration.

In addition to being an interactive reservoir of water and nutrients, South Florida's wetland soils and sediments are a repository of historical information about the system. The peat deposits and bay sediments contain a record of changing vegetation and ecosystem biogeochemistry that reflects both natural variations and human influence over time. We must understand the natural cycles and predevelopment baseline conditions of this system in order to assess and attempt to minimize the effects of human disturbance. Analysis of the soils and sediments is helping to provide this insight.

Human activities have led to the deterioration of the productivity, biodiversity, and stability of the ecosystem (Boesch and others, 1993; Davis, 1994). Agricultural activities and intensive flood control efforts have severely altered the region's hydrology, changed water levels in the Everglades, and limited the periodic freshwater flushing of Florida Bay. Agricultural runoff also has increased levels of phosphorus and other substances in drainage canals and bordering wetlands, leading to large changes in plant communities (Davis, 1994). Also, mercury has been found in high concentrations in fish, birds, and mammals; mercury contamination is thought to have contributed to the near extinction of the Florida panther (Roelke and others, 1991), and it may pose a health hazard to local inhabitants. Major anthropogenic sources of mercury include atmospheric deposition from fossil fuel combustion and urban emissions, and, possibly, agricultural runoff (Lambou and others, 1991; Delfino and others, 1993).

Although predevelopment water quality data are not directly available, water quality is reflected in the geochemistry of peat cores from the wetlands. Previous studies have found large increases in phosphorus and mercury in the upper $30 \mathrm{~cm}$ of peat cores, reflecting increased inputs of these elements over the last century (Koch and Reddy, 1992; Craft and Richardson, 1993;
Delfino and others, 1993). However, concentrations vary locally, possibly because of variations in the accumulation rate of the peat. The rapid deposition and preservation of plant material could have a diluting effect on the concentrations of these elements. Alternatively, other changes, such as variations in local hydrology, plant types, carbonate abundance, nutrient availability, and sulfur geochemistry, may have a role in controlling the distribution of $\mathrm{p}^{\text {hospho- }}$ rus and mercury.

Our initial results from cores collected from several representative locations in the Everglades confi-m that peat accumulation rates have varied greatly over the last century, and that the variations appear to reflect differences in local hydrology and nutrient inputs. Low water levels may be responsible for low peat accumulation and the highly degraded nature of the peat in some areas. Extended periods of exposure of the peat to air during dry seasons may have led to oxidation of peat with lit'le additional accumulation. Environmentally important $\boldsymbol{c}^{\prime}$ ements may have been oxidized, leached, and remobilized from exposed peat. Areas that remained under water show greater and more continuous accumulations of peat. These results illustrate the importance of hydrologic conditions to changes in the chemistry of wetland soils. Th: extent to which inundation patterns and rates of peat accumulation may be responsible for variations in environmentally significant metals is a focus of our ongoing studies.

Variations in paleoecology are reflected in the plant remains preserved in the peat and in the organic g?ochemistry and stable isotope composition of the peat. $\mathrm{O} r \mathrm{r}$ initial results reveal differences in the chemistry and preservation of peat derived from sawgrass, water-lily, and periphyton algae and associated sediments. These differences reflect rates and degrees of decomposition which may be important factors affecting metal distributions and cycling.

These biogeochemical studies of South Floric'a's wetland soils and sediments will provide a historical perspective of ecosystem conditions and natural variability. This perspective can augment the predictive capabilities used by resource managers to make informed decisions concerning restoration efforts and to avoid costly mistakes. These studies exemplify an important role of the U.S. Geological Survey-that is, to provide impartial expert technical information that can clarify resource management issues.

\section{REFERENCES}

Boesch, D.F., Armstrong, N.E., D'Elia, C.F., Maynard, N.G., Paerl, H.W., and Williams, S.L., 1993, Deterioration of the Florida Bay Ecosystem-An evaluation of the scientific evidence: Report to the Interagency Working Group on Florida Bay, September 15, 1993, $28 \mathrm{p}$.

Craft, C.B., and Richardson, C.J., 1993, Peat accretion and phosphorus accumulation along a eutrophic gradient in th $:$ northern Everglades: Biogeochemistry, v. 22, p. 133-156.

Davis, S.M., 1994, Phosphorus inputs and vegetation sensitivity in the Everglades, in Davis, S.M., and Ogden, J.C., eds., 
Everglades-The ecosystem and its restoration: Delray Beach, Fla., St. Lucie Press, p. 357-378.

Davis, S.M., and Ogden, J.C., eds., 1994, Everglades-The ecosystem and its restoration: Delray Beach, Fla., St. Lucie Press, $826 \mathrm{p}$.

Delfino, J.J., Crisman, T.L., Gottgens, J.F., Rood, B.E., and Earle, C.D., 1993, Spatial and temporal distribution of mercury in Everglades and Okefenokee wetland sediments: Final Project Report, April 1, 1991-June 30, 1993, Department of Environmental Engineering Sciences, University of Florida, Gainesville, June 30, 1993.

Koch, M.S., and Reddy, K.R., 1992, Distribution of soil and plant nutrients along a trophic gradient in the Florida Everglades: Soil Science of America Journal, v. 59, no. 1492-1499, 140 p.

Lambou, V.W., Barkey, T., Braman, R.S., Delfino, J.J., Jansen, J.J., Nimmo, D., Parks, J.W., Porcella, D.B., Rudd, J., Schultz, D., Stober, J., Watras, C., Wiener, J.G., Gill, G., Huchabee, J., and Rood, B.E., 1991, Mercury Technical Advisory Committee Interim Report to the Florida Governor's Mercury in Fish and Wildlife Taskforce \& the Department of Environmental Regulation: Tallahassee, Fla., Center for Biomedical \& Toxicological Research and Waste Management, 60 p.

Light, S.S., and Dineen, J.W., 1994, Water control in the Everglades; a historical perspective, in Davis, S.M., and Ogden, J.C., eds., Everglades - The ecosystem and its restoration: Delray Beach, Fla., St. Lucie Press, p. 47-84.

Roelke, M.E., Scheltz, D.P., Facemire, C.F., Sandlof, S.F., and Royals, H.E., 1991, Mercury contamination in Florida panthers: Prepared by the Technical Subcommittee of the Florida Panther Interagency Committee.

\section{Springtime Emission of Methane from North Temperate Lakes}

\author{
Robert G. Striegl and \\ Catherine M. Michmerhuizen, \\ U.S. Geological Survey, Denver, CO 80225
}

\section{Introduction}

Determining the amounts of carbon gases emitted from lakes and wetlands is important not only to understanding the processes that control carbon cycling in aquatic environments, but also to understanding the influence of freshwater systems on the global carbon cycle. Emission of methane $\left(\mathrm{CH}_{4}\right)$ from lakes and wetlands is an important source of atmospheric $\mathrm{CH}_{4}$, a greenhouse gas that is increasing in concentration in the atmosphere (Raynaud and Chappellaz, 1993; Matthews, 1993). However, the seasonality of $\mathrm{CH}_{4}$ loss from lakes and the relative importance of lake physical, chemical, and biological factors on gas emissions are not well known. Because of this, it is difficult to accurately quantify $\mathrm{CH}_{4}$ emissions from areas such as the north temperate lakes region of Minnesota and Wisconsin that have many lakes and wetlands of varying size, setting, and trophic condition.
Lake $\mathrm{CH}_{4}$ production is ultimately linked to the amount of organic material that is available for decomposition. Therefore, areally averaged lake $\mathrm{CH}_{4}$ emission should be proportional to the average loading of organi : carbon to sediments, to lake biological production, and to the relative amount of littoral zone macrophyte productic $\eta$ - small, shallow, productive lakes should emit more $\mathrm{CF}_{1}$ per unit area than large, deep, less productive lakes.

\section{Purpose and Scope}

Our goal is to relate common lake and watershed characteristics to annual rates of lake $\mathrm{CH}_{4}$ emission so that regional lake emissions to the atmosphere can be more accurately estimated-a difficult task because lake gas emissions vary greatly with season and are controlled lc rally by factors such as temperature, wind, lake mixing, and gas production and consumption rates. For this study, we tracked seasonal $\mathrm{CH}_{4}$ emission at two lakes, Williams Lake and Shingobee Lake in Hubbard County, Minnesota, and surveyed potential $\mathrm{CH}_{4}$ emission at springtime ice melt at an additional 18 lakes in Minnesota and Wisconsin in 1993.

The 20 lakes span more than four orders of magnitude in lake size in four settings (table 1): carbor ate till in Hubbard and Cass Counties near Walker, Minn (CT), noncarbonate till in Vilas County near Boulder Junction, Wis. (NCT), Precambrian Shield in Lake County near Ely, Minn. (PS), and lakes in the Minneapolis metropolitan area (MMA).

\section{Methods}

Samples were kept isolated from the atmosphere by pumping lake water directly into polyprorylene syringes having three-way nylon stopcocks. Dissolve $\mathrm{CH}_{4}$ concentrations were determined by equilibrating the lake water with an equal volume of nitrogen and analying the head space with a gas chromatograph having a fame ionization detector. The ambient dissolved $\mathrm{CH}_{4}$ con entration was determined from the headspace concentration using established gas-water distribution coefficients (Yamamoto and others, 1976).

Dissolved $\mathrm{CH}_{4}$ concentrations were measured throughout the water column at the deepest locations of the lakes or lake basins sampled. Total lake storage of dissolved $\mathrm{CH}_{4}$ (moles of $\mathrm{CH}_{4}$ per lake) was calculated from the depth versus concentration profile and from depth versis lake volume values digitized from lake contour maps. Hotizontal mixing of $\mathrm{CH}_{4}$ was assumed at this time of spring turnover.

$\mathrm{CH}_{4}$ storage versus time was measure f for Williams and Shingobee Lakes from spring $1992 \mathrm{t}^{\text {through August }}$ 1993. Measurements during winter and spring showed that $\mathrm{CH}_{4}$ gradually builds up in the lakes under ire cover, and is released to the atmosphere following ice melt. The time around ice melt was thus ideal for a comparative survey of the potential for $\mathrm{CH}_{4}$ emission from severa' lakes because 

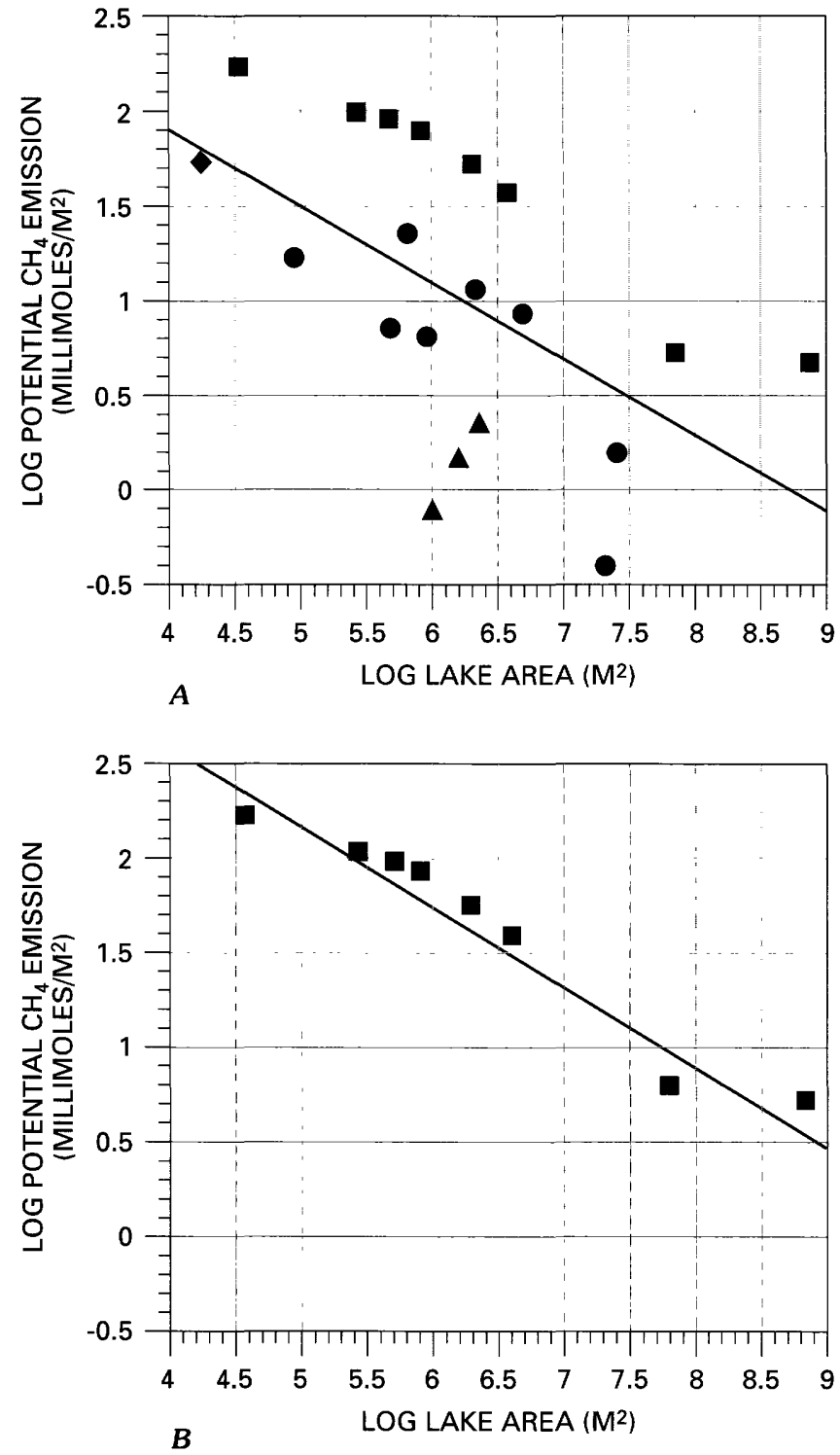

(1) all lakes experienced similar periods of ice cover at nearly identical water temperatures, (2) $\mathrm{CH}_{4}$ oxidation is slow or negligible in winter, and (3) episodic gas losses from bubbling or wind action are essentially nil when lakes are ice covered.

We measured lake $\mathrm{CH}_{4}$ storage just before and just after ice melt and used the greater of the two measured storage values to calculate potential emission to the atmosphere. Potential emission was calculated as the area averaged difference between the measured $\mathrm{CH}_{4}$ storage and the amount of $\mathrm{CH}_{4}$ that would be in the lake if the atmosphere were the only source of dissolved $\mathrm{CH}_{4}$.

\section{Results}

$\mathrm{CH}_{4}$ storage and potential emission have two cycles annually in Williams and Shingobee Lakes that can be explained in terms of competing net $\mathrm{CH}_{4}$ production in the

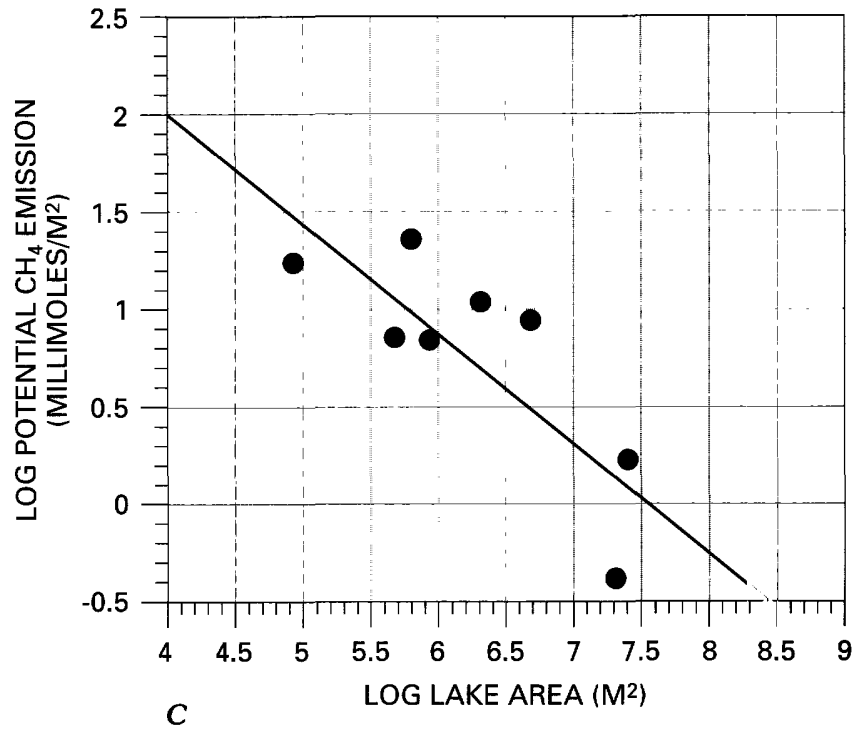

\section{EXPLANATION}

Soft sediments

Sand and rock bottom

A Urban lake

- Bog

Figure 1 (Striegl and Michmerhuizen). Log of potential $\mathrm{CH}_{4}$ emission versus log of lake area. $A$, all 20 lakes, Minnesota and Wisconsin; $B, 8$ lakes having organic-rich sediments in the $1^{1: t}$ toral zone and high macrophyte densities, Minnesota; $C, 8$ lakes baving sandy or rocky littoral zones and low macrophyte densities. Minnesota and Wisconsin.

lakes and emission from the lakes to the atmosphere. As springtime temperatures rise, net $\mathrm{CH}_{4}$ production exceeds emission, and dissolved $\mathrm{CH}_{4}$ storage increases steadily until late summer. Most of the stored $\mathrm{CH}_{4}$ is in deep lak? waters that are not in direct contact with the atmosphere. In early fall, net $\mathrm{CH}_{4}$ production slows as water and sediment temperatures cool and decomposition slows. During anc following fall overturn, the stored $\mathrm{CH}_{4}$ in deep water is bror ght into contact with the atmosphere and rapid lake degassing occurs. Degassing continues more slowly until ice forms, and $\mathrm{CH}_{4}$ emission to the atmosphere ceases when full ice cover is established. Ice cover allows for buildup of dissolved $\mathrm{CH}_{4}$ in lake water that continues until ice melt. Rapid degassing of the lake is repeated following ice melt and spring overturn. This is followed by a period of more gradual loss until temperatures increase, net $\mathrm{CH}_{4}$ production exceeds emission, and increases in summertime $\mathrm{CH}_{4}$ concentration recur.

The buildup of $\mathrm{CH}_{4}$ storage under ice cover was used to compare potential for loss of $\mathrm{CH}_{4}$ to the atmosphere for 20 lakes during spring of 1993. Potential emission ranged from 
Table 1 (Striegl and Michmerhuizen). Location, size, and potential $\mathrm{CH}_{4}$ emission of lakes sampled

[CT, carbonate till, Minnesota; NCT, noncarbonate till, Wisconsin; PS, Precambrian Shield, Minnesota; MMA, Minneapolis metropolitan area, Minnesota)]

\begin{tabular}{|c|c|c|c|c|c|}
\hline Lake & Setting & $\begin{array}{l}\text { Lat } \\
\text { N. }\end{array}$ & $\begin{array}{l}\text { Long } \\
\text { W. }\end{array}$ & $\begin{array}{l}\text { Lake area } \\
\qquad\left(\mathrm{m}^{2}\right)\end{array}$ & $\begin{array}{l}\text { Poten. emission } \\
\left.\text { (millimole } \mathrm{CH}_{4} / \mathrm{m}^{2}\right)\end{array}$ \\
\hline Little Shingobee & CT & $46^{\circ} 59^{\prime}$ & $94^{\circ} 41^{\prime}$ & 27,120 & 185.4 \\
\hline Williams & CT & $46^{\circ} 57^{\prime}$ & $94^{\circ} 40^{\prime}$ & 370,900 & 94.7 \\
\hline Shingobee & CT & $47^{\circ} 00^{\circ}$ & $94^{\circ} 41^{\prime}$ & 655,100 & 83.2 \\
\hline 11th Crow Wing & CT & $46^{\circ} 48^{\prime}$ & $94^{\circ} 44^{\prime}$ & $2,997,000$ & 38.3 \\
\hline Leech & $\mathrm{CT}$ & $47^{\circ}$ & $94^{\circ}$ & $573,400,000$ & 15.6 \\
\hline Crystal Bog & NCT & $46^{\circ} 00^{\prime}$ & $89^{\circ} 36^{\prime}$ & 14,160 & 61.3 \\
\hline Crystal & NCT & $46^{\circ} 00^{\circ}$ & $89^{\circ} 37^{\prime}$ & 378,900 & 7.2 \\
\hline Allequash & NCT & $46^{\circ} 02^{\prime}$ & $89^{\circ} 37^{\prime}$ & $1,612,000$ & 11.5 \\
\hline Big Muskellunge & NCT & $46^{\circ} 01^{\prime}$ & $89^{\circ} 37^{\prime}$ & $3,841,000$ & 9.3 \\
\hline Trout & $\mathrm{NCT}$ & $46^{\circ} 02^{\prime}$ & $89^{\circ} 40^{\prime}$ & $15,610,000$ & 0.4 \\
\hline Glacier Pond & PS & $47^{\circ} 57^{\prime}$ & $91^{\circ} 34^{\prime}$ & 72,300 & 18.6 \\
\hline Tofte & PS & $47^{\circ} 58^{\prime}$ & $91^{\circ} 35^{\prime}$ & 506,100 & 24.1 \\
\hline Jasper & PS & $47^{\circ} 58^{\prime}$ & $91^{\circ} 33^{\prime}$ & 758,400 & 6.8 \\
\hline Ojibway & PS & $47^{\circ} 57^{\prime}$ & $91^{\circ} 33^{\prime}$ & 411,300 & 54.7 \\
\hline Snowbank & PS & $48^{\circ} 00^{\circ}$ & $91^{\circ} 25^{\prime}$ & $20,040,000$ & 1.6 \\
\hline Hiawatha & MMA & $44^{\circ} 55^{\prime}$ & $93^{\circ} 14^{\prime}$ & 216,989 & 103.6 \\
\hline Nokomis & MMA & $44^{\circ} 54^{\prime}$ & $93^{\circ} 14^{\prime}$ & 805,486 & 0.88 \\
\hline Harriet & MMA & $44^{\circ} 55^{\prime}$ & $93^{\circ} 18^{\prime}$ & $1,194,762$ & 1.5 \\
\hline Calhoun & MMA & $44^{\circ} 57^{\prime}$ & $93^{\circ} 18^{\prime}$ & $1,720,011$ & 2.3 \\
\hline Minnetonka & MMA & $44^{\circ} 55^{\prime}$ & $93^{\circ} 35^{\prime}$ & $53,010,000$ & 5.3 \\
\hline
\end{tabular}

$0.4 \mathrm{mmol} / \mathrm{m}^{2}$ (millimole $\mathrm{CH}_{4}$ per meter squared) for Trout Lake, the largest lake in the NCT area, to $185.4 \mathrm{mmol} / \mathrm{m}^{2}$ at Little Shingobee Lake, the smallest lake in the CT area (table 1). In general, potential emission was inversely proportional to lake area (fig. 1A). This is consistent with our hypothesis that lakes having small areas and large littoral zone macrophyte production should have larger $\mathrm{CH}_{4}$ emissions per unit area than larger but less productive lakes. Lakes having soft organic-rich sediments and high macrophyte densities had the largest potential emission to the atmosphere, and had a very consistent relation between potential emission and total lake area (fig. $1 B, r^{2}=0.948$ ). These included Little Shingobee, Williams, Shingobee, Eleventh Crow Wing, and Leech Lakes (CT), Hiawatha and Minnetonka Lakes (MMA), and Ojibway Lake (PS). This suggests that $\mathrm{CH}_{4}$ emission is strongly linked to the sediment source and that dead macrophytes from littoral zones provide much of the substrate for $\mathrm{CH}_{4}$ production.

Crystal Bog in the NCT area had appreciably less potential $\mathrm{CH}_{4}$ flux than similar-sized lakes having soft sediments (diamond, fig. 1A). Reasons for this are not clear, but include possible inhibition of $\mathrm{CH}_{4}$ production at the low pH's encountered in bog sediments.

Lakes having predominantly sandy or rocky bottoms and small macrophyte densities (Glacier Pond, Tofte, Jasper, and Snowbank (PS), and Crystal, Allequash, Big Muskellunge, and Trout (NCT)) also exhibited a strong inverse relation between potential $\mathrm{CH}_{4}$ emission and lake area (circles and lower line, fig. $1 C, r^{2}=0.636$ ), but potentials were smaller than for lakes having soft sediments.
The lines defined in figure 1 , views $B$ and $C$, provide a range for potential $\mathrm{CH}_{4}$ emission followir? ice melt that could be expected for relatively undisturbed lakes in Minnesota and northern Wisconsin. However, the effects of cultural disturbances on these potentials are uncertain. MMA lakes Nokomis, Harriet, and Calhoun (triangles, fig. 1A) clearly have less potential emission than oth?r lakes of similar size, regardless of bottom type. These lakes have received urban runoff for decades and have harvesting programs to remove nuisance macrophytes. Removal of macrophytes from lakes must reduce gas production somewhat, but other factors, such as inhibition of $\mathrm{CH}_{4}$ production by pollutants in urban runoff and historical applications of macrophyte inhibitors such as copper sulfate, $c^{\prime}$ so need to be considered. Lakes affected by other kinds of cultural disturbances, such as agricultural runoff, were not sampled.

\section{REFERENCES}

Matthews, E., 1993, Wetlands, chapter 15 in Kl alil, M.A.K., ed., Atmospheric methane-Sources, sinks, ard role in global change: New York, Springer-Verlag, p. 314-361.

Raynaud, D., and Chappellaz, J., 1993, The reccrd of atmospheric methane, chapter 3 in Khalil, M.A.K., ed., A tmospheric methane-Sources, sinks, and role in global change: New York, Springer-Verlag, p. 38-61.

Yamamoto, S., Alcauskas, J.B., and Crozier, T.E., 1976, Solubility of methane in distilled water and seawater: Jcurnal of Chemical Engineering Data, v. 21, p. 78-80. 


\section{Environmental Effects of Energy Extraction and Utilization}

The Effects of Oil-Field Brines on

\section{Aquifers-Tracing the Movement of Brines Using Geochemical Tools}

\author{
Marvin M. Abbott, U.S. Geological Survey, 202 \\ NW 66th, Building 7, Oklahoma City, OK 73116
}

Geochemical techniques using dissolved ionic species and stable isotopes of water can be a useful tool in the identification of the source of brine that may infiltrate aquifers in areas of oil and gas production. (See also Craigg and Thamke (this volume) for studies in another region.) Our study area was in northeastern Oklahoma between Tulsa and Oklahoma City. Brine is defined as water that has TDS (total dissolved solids) of greater than $35,000 \mathrm{mg} / \mathrm{L}$ (milligrams per liter). Eleven water-quality samples were collected from four cluster wells. Each well was constructed to sample from selected single zones, grouped by depth into shallow (0-200 feet), intermediate (200-250 feet), and deep (500 feet). Seven shallow-depth samples were from fresh-water aquifers beneath which were indications of salt-water encroachment. These shallow-depth samples were assumed to represent the fresh ground water in the area. Three intermediate-depth samples were located less than a half-mile apart in areas of suspected brine encroachment. The location of the well for the deep sample, located 2 miles from the intermediate-depth sample localities, was selected because there was no indication of salt-water encroachment in the stratigraphic equivalent intermediate zones. The intermediate and deep samples were taken from sandstones immediately below what was considered the base of fresh ground water at each site. These salt-water samples were compared to brines from oil production near the localities of the intermediate-depth wells.

The oil production is from a Lower Pennsylvanian sandstone at 3,000 feet. A secondary-recovery waterflood of the oil-producing formation has been operating since 1952 near the localities of the intemediate wells. Four brine samples were collected from oil wells at the producing well head. One brine sample was collected at the pressure pump of the injection system of the waterflood. The deep sample locality is also near oil production that has been waterflooded in the same formation, since the early 1950 's. The two waterflood units are considered to be separate structurally and not in communication.

All analyses were determined by the U.S. Geological Survey National Water Quality Laboratory in Denver, Colo. Knowledge of the analytical methods used and the number of dilutions required for the analyses of brines is important in understanding the limitation of the data reported. The samples that had higher TDS required dilutions before the analyses could be made. Each dilution is allowed a small percentage tolerance of error. Likewise the analytical procedure has an error tolerance that is monitored by the Jaboratory. These errors individually are small but are cumulative in nature.

The sampling methods, the location, and the stratigraphic units sampled must be planned carefully in o-der to minimize variables and unknowns. The history of both the oil production and the waterflood operations is neeted to understand what sampling is required and where it shcild be done. Other salt-water injections and disposals in th $\bullet$ area must be known. Any completion or stimulation practice in the oil-producing formation or waterflood that mav' have affected the composition of the brine samples should $\mathrm{k}$, considered as to its potential effect.

The uses of stable isotopes in characterizing the origin of water molecules are discussed in Gat and Gonfiantini (1981), and the application to saline formation waters is described in Clayton and others (1966). Isotopic composition of ground water is influenced most strongly by rockwater interaction. Two examples of this are the membrane effects of clay minerals (Coplen and Hanshaw, 1973) and the dissolution of limestones and dolomites that releases additional oxygen into ground water. If the residence time is maintained long enough, as in the case of deeper form *tions, the ground water will approach an isotopic equilibrium with the aquifer.

Gat and Gonfiantini (1981) and Craig (1966) dis ussed the use of graphical methods for ground-water characterization that combine salinity and stable isotopes. Figure. 1 is a plot of the chloride molality versus $\delta^{18} \mathrm{O}$ (oxygen-18 measurement relative to standard mean ocean water in parmil). Chloride was selected because it reacts little with other chemical species in the ground water or with litholories of the aquifers. The molality values were calculated by WATEQF from the input program for the computer program NETPATH (Plummer and others, 1991).

Mixing two types of water, such as the shallow-depth samples and the oil brine, will produce a straight line on the plot. The five shallow-depth samples are fresh ground water and plot along zero molality in figure 1 . Since the cil-producing formation has been waterflooded, the original isotopic composition of the oil-brine water is not known. The oilbrine samples plot along a straight line in figure 1, srogesting a mixing of the original brine composition with a diluting fresher water. The specific conductance of the oil-brine samples ranged from 110,000 to $160,000 \mu \mathrm{S} / \mathrm{cm}$ (mi rosiemens per centimeter) at $25^{\circ} \mathrm{C}$. Two of the intermediatedepth samples also plot along the mixing line. Thes: samples are products of mixing the oil brine and fresh ground 


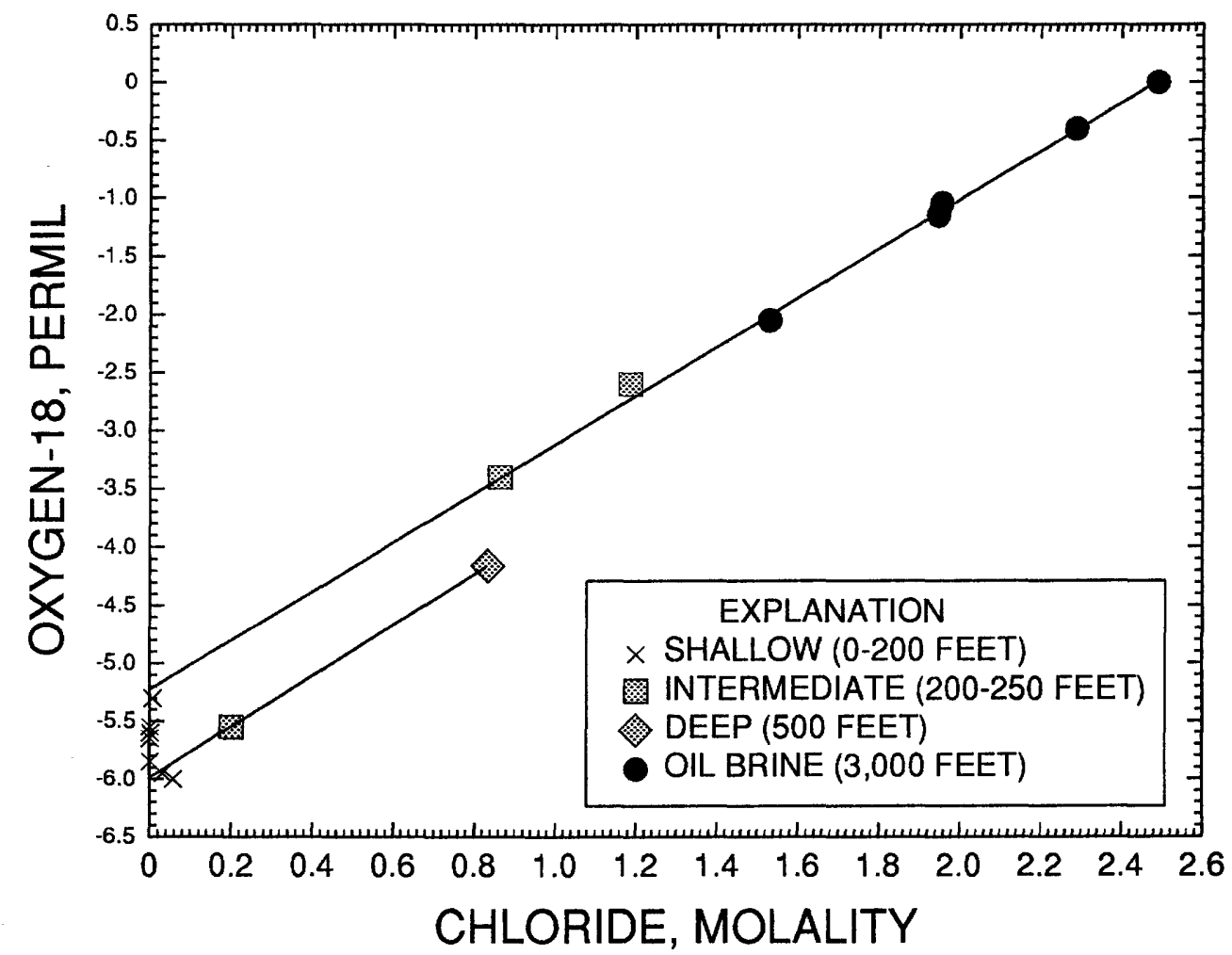

Figure 1 (Abbott). Relation between oxygen-18 and chloride molality.

water. Specific conductance of these samples was greater than 75,000 and $95,000 \mu \mathrm{S} / \mathrm{cm}$. A third intermediate-depth sample and the deep sample also had higher chloride values but did not plot on the mixing line with the oil brines. These two samples had specific conductances greater than 25,000 and $70,000 \mu \mathrm{S} / \mathrm{cm}$, respectively. These samples were slightly more depleted in the $\delta^{18} \mathrm{O}$ than the samples that plotted along the oil-brine mixing line. These samples were thought to be a mixture of fresh ground water with an unknown brine. The unknown brine would also be more depleted in the $\delta^{18} \mathrm{O}$ isotope oil-brine samples.

\section{REFERENCES}

Clayton, R.N., Friedman, I., Graf, D.L., Mayeda, T., Meents, W.F., and Shimp, N.F., 1966, The origin of saline formation waters: Journal of Geophysical Research, v. 71, p. 3869.

Coplen, T.B., and Hanshaw, B.B., 1973, Ultrafiltration by a compacted clay membrane-Oxygen and hydrogen fractionation: Geochimica et Cosmochimica Acta, v. 37, p. 2295-2310.

Craig, H., 1966, Isotopic composition and origin of the Red Sea and Salton Sea geothermal brines: Science, v. 154, p. 1544.

Gat, J.R., and Gonfiantini, R., eds., 1981, Stable isotope hydrology, deuterium and oxygen-18 in the water cycle: Vienna, Technical Reports Series No. 210, International Atomic Energy Agency, p. 339.
Plummer, L.N., Prestemon, E.C., and Parkhurst, D.L., 1991, An interactive code (NETPATH) for modeling ret geochemical reactions along a flow path: U.S. Geological Survey WaterResources Investigations Report 91-4078, p. 227.

\section{U.S. Bureau of Mines Research irto the Environmental Effects of Energy Resource Development}

T.E. Ackman, R.F. Chaiken, A.G. Kim, S.J. Schatzel, D.E. Siskind, and M.A. Trevits; all authors are U.S. Bureau of Mines, Pittsburgh Research Center, Pittsburgh, PA, exc.ept D.E. Siskind, USBM, Twin Cities Re earch Center, Minneapolis, MN

The U.S. Bureau of Mines (USBM) is actively conducting research addressing a spectrum of mining-induced environmental problems. This work incl des studies that focus not only on the extraction operatior. but also on the short- and long-term impact of the operation on the local 
environment. Some of the key research areas include fires in abandoned underground coal mines, disposal of coal combustion residues, evaluation of in-place gas content, and control of vibrations produced by blasting at surface coal mines. This paper provides short vignettes into each of these areas.

\section{Fires in Abandoned Coal Mines}

There are currently 100 fires in abandoned underground coal mines and 200 fires in abandoned coal waste banks. Surface subsidence and the emission of toxic fumes and gases are the most serious effects of such fires; the deterioration in air quality and the decline in the value of adjacent properties may affect a population that had no connection to the original mining activity. Efforts to control such fires by conventional methods are usually expensive, may be hazardous, and have a relatively low probability of success.

The USBM has developed a method to control the subsurface combustion and incorporate utilization of the heat, thus converting a source of pollution to an energy resource. The patented Burnout Control Process uses exhaust ventilation to promote the complete burning of an underground fire while allowing total management of the hot gases produced. An exhaust fan coupled to a ductwork system that is connected to the underground fire pulls a vacuum on the mine, drawing air through natural cracks and fractures or through inlet boreholes. The increased airflow intensifies the fire, and all heat and gases are drawn to a single exhaust point. The hot flue gases can pass through a heat exchanger or waste boiler to produce electricity, steam, or process heat. This process was successfully field tested for 4 months at a shallow drift mine and over a 1-year period at a burning coal waste bank.

\section{Disposal of Coal Combustion Residues in Inactive Surface Mines}

The disposal of coal combustion residues (CCR) in surface and underground coal mines provides a stable, lowmaintenance alternative to landfills, benefiting the mining and electric power industries. The material is also expected to improve water quality at acid-generating abandoned or reclaimed coal mine sites. Most combustion residues are alkaline, and their addition to the subsurface environment raises the $\mathrm{pH}$, limiting the propagation of pyrite-oxidizing bacteria, and reducing the rate of acid generation. Many of the CCR's are also capable of forming cementitious grouts that when injected into the buried spoil decrease its permeability and porosity and divert water away from the pyritic material. Both mechanisms, alkaline addition and water diversion, are expected to reduce the amount of acid produced at the disposal site.
The USBM is cooperating in a test of subsurface injections of CCR's into a reclaimed surface mine. Initially, a mixture of fly ash, lime, and AMD (acit mine drainage) sludge was injected. Lime was the source of calcium for the formation of a pozzuolanic grout. Wr en fluidized bed combustion ash produced by burning coal or coal refuse with limestone was used (instead of fly ash from conventional power plants), the addition of lime was not necessary. Changes in water quality paramete-s $(\mathrm{pH}$, acidity, anions, and cations) in water samples from wells and seeps at the field site were monitored to assess the effect of CCR injection. After injection of the fly ash grout, the total acidity decreased at the monitorin : sites. Similar trends were observed for ferrous iron, tot ${ }^{-1}$ iron, aluminum, and sulfate.

\section{The Modified Direct Method for Gas Content Evaluation}

The USBM has developed the modified direct method (MDM) of gas content determination to evaluate the methane gas emission potential in oil shale mines. The terhnique has been utilized to accomplish a variety of tasks re'ited to coalbed methane. The MDM has demonstrated applications for resource estimations, environmental issues suct as the estimation of the release of mining-related greenhouse trace gases into the atmosphere, and mine safety, by identifying gas sources and their associated gas content. One of the significant advantages of the method is the high degree of accuracy. High resolution also makes the MDM ideal for gas content determination of noncoal samples and low gas content coals (low rank or near-surface deposits). The detection of gases emitted other than methane is a valuable a set for utilization concerns where removal of carbon dioxid: or the upgrading of coalbed gas may be an important economic consideration.

\section{Control of Vibrations Produced by Blasting in Surface Coal Mines}

The USBM has had a pivotal role in determiring the environmental impacts of mine blasting, specifically ground vibration and airblast effects on structures. These include assessment procedures and the development of safe-level criteria which have been adopted by Federal and State agencies. In some cases, local regulatory bodies have used these procedures to ensure that those living near mining and construction blasting operations are provided with adequate protection. Studies have examined factors influencing $v^{\text {ihration }}$ generation, propagation, and control through design. Recent work has focused on safe blasting techniques to allow for efficient and practical coal mining near pressurized transmission pipelines. 


\section{Acid Rain}

O.P. Bricker, U.S. Geological Survey, Reston, VA 22092, and K.C. Rice, U.S. Geological Survey, Charlottesville, VA 22903

Although acid rain is fading as a political issue in the United States and funds for research in this area have largely disappeared, the acidity of rain in the Eastern United States has not changed significantly over the last decade, and it continues to be a serious environmental problem. Acid deposition (commonly called acid rain) is a term applied to all forms of atmospheric deposition of acidic substances-rain, snow, fog, acidic dry particulates, aerosols, and acid-forming gases. Water in the atmosphere reacts with certain atmospheric gases to become acidic. For example, water reacts with carbon dioxide in the atmosphere to produce a solution with a pH of about 5.6. Gases that produce acids in the presence of water in the atmosphere include carbon dioxide (which converts to carbonic acid), oxides of sulfur and nitrogen (which convert to sulfuric and nitric acids), and hydrogen chloride (which converts to hydrochloric acid). These acid-producing gases are released to the atmosphere through natural processes, such as volcanic emissions, lightning, forest fires, and decay of organic matter. Accordingly, precipitation is slightly acidic, with a $\mathrm{pH}$ of 5.0 to 5.7 even in undeveloped areas. In industrialized areas, most of the acidproducing gases are released to the atmosphere from burning fossil fuels. Major emitters of acid-producing gases include power plants, industrial operations, and motor vehicles. Acid-producing gases can be transported through the atmosphere for hundreds of miles before being converted to acids and deposited as acid rain. Because acids tend to build up in the atmosphere between storms, the most acidic rain falls at the beginning of a storm, and as the rain continues, the acids "wash out" of the atmosphere.

Acid rain can affect the quality of surface water in two ways - by chronic acidification or by episodic acidification. Chronic acidification of a body of water results from a continuous input of acid rain over a period of years. This continuous acidic input to the body of water may slowly cause changes in the water chemistry. If the acidic input continues unabated, then the lake or stream eventually will no longer be capable of neutralizing the acidity, and the water becomes acidified. A quantitative measure of the ability of a body of water to neutralize acidity is the acid-neutralizing capacity (ANC). A high ANC means that the water is capable of neutralizing large amounts of acidity, whereas a low ANC means that the water has little capacity to neutralize acidity and may become acidified. One of the major factors that determines how quickly or slowly a body of water will acidify is the type of bedrock or sediment underlying the watershed. For example, water in a stream or lake that traverses or overlies limestone, which comprises calcium carbonate, commonly has a high ANC and is said to be well buffered. In contrast, many lakes in the Adirondack Mountains of northern New York State are underlain by granite, which comprises silicate minerals, and the water has a very low ANC; in fact, many lakes in the Adirondack: are acidified.

Episodic acidification of a stream or lake can happen over a short time as a result of input from a single rainstorm or period of snowmelt. During a rainstorm, the acidic rain may be quickly routed by way of surface and shallow subsurface flow to the stream or lake, where the influx of acidic water causes the $\mathrm{pH}$ and $\mathrm{ANC}$ of the water $\mathrm{t}$ ) decrease. The decrease in $\mathrm{pH}$ and $\mathrm{ANC}$ can happen within minutes after the storm begins, and the effect can last for hours or days. The amount of decrease in $\mathrm{pH}$ and ANC in a borly of water as a result of episodic acidification depends on many factors. The type of bedrock or sediment that underlies the watershed affects the $\mathrm{pH}$ and ANC of the streamwater during nonstormflow conditions (base flow). A well-buffered watershed system, such as one underlain by limest one, will have a higher $\mathrm{pH}$ and ANC during base-flow conditions than a poorly buffered system, such as one underlain by granite. Even though the decrease in $\mathrm{pH}$ and $\mathrm{ANC}$ during a storm in a well-buffered watershed may be greater $t^{\text {than }}$ in a poorly buffered watershed, the water quality generally does not deteriorate to a level harmful to aquatic org nisms. In contrast, streams in poorly buffered watersheds can quickly lose all ANC, which causes the stream to become acidified during storms. This sudden increase in acidity can cause aquatic organisms (particularly fin fish and amphibians) to suffer "acid shock." During rainstorms, a well-buf ${ }^{c}$ ered watershed with long flow routes may be able to neutralize most of the incoming acidity before it reaches the strea $\eta$, and thus the amount of episodic acidification in the stream will not be large. A poorly buffered watershed with stort flow routes will allow large amounts of acidic water to q ickly reach the stream, thus causing a large amount of episodic acidification. In contrast to the preceding two examples, $\Sigma$ watershed that is chronically acidified will be little affected by episodic acidification because the streamwater alrearly has virtually no $\mathrm{ANC}$ and has the same $\mathrm{pH}$ as the incorring rain. Other factors that can influence the severity of episodic acidification include intensity and duration of the incoming rain, $\mathrm{pH}$ of the rain, season (summer growing season as opposed to winter dormant season), and the length of tine since the preceding rainfall, which affects the moisture cc ntent of the soil and the shallow subsurface routes for the acidic rain to reach the stream.

Despite the declining interest in acid rain in the political arena and among the public, the acidity of rain in the Eastern United States has not declined significar ly in the last decade. Acid rain continues to affect the qrality of surface and ground waters in regions underlain by bedrock and surficial deposits that have low-buffer capacity. Current mitigation techniques (for example, liming) can orly be applied to a small fraction of affected waters and, at best, are only a 
temporary "fix." The acid rain problem will not improve until adequate measures are taken to reduce sulfur and nitrogen emissions at their sources. Some progress has been made to reduce harmful emissions (such as using catalytic converters on automobiles, coal washing to remove sulfur compounds, stack scrubbers and improved burners for boilers). But there is still a long way to go to bring emissions of sulfur and nitrogen compounds to acceptable levels with regard to environmental effects. In the meantime, continuing research on acid rain, and particularly its effects on watershed systems, is necessary to track changes in the quality of waters in sensitive regions and in the health of the aquatic biota they support.

\section{Energy-Related Selenium and Vanadium Contamination in San Francisco Bay, California-Effects on Biological Resources?}

\author{
Cynthia L. Brown and Samuel N. Luoma, \\ U.S. Geological Survey, Menlo Park, CA 94025
}

\section{Introduction}

Environmental impacts must be included in determining the costs of using petroleum as an energy source. One of the impacts associated with petroleum refining and product combustion is release of potentially toxic wastes. Inorganic wastes that result from production and consumption of petroleum-derived energy include selenium and vanadium. Elevated concentrations of selenium and vanadium are found throughout much of North San Francisco Bay near where waste from refineries could affect the estuary. Although some knowledge of the environmental toxicity of selenium in the area exists, little is known about vanadium.

\section{Study Site and Methods}

North San Francisco Bay (North Bay) is a complex estuarine system located at the mouths of the Sacramento and San Joaquin Rivers. The rivers drain about 40 percent of the land area of California. Their inflows to the bay follow the highly seasonal pattern of precipitation over California and the operation of one of the world's largest man-made water-management systems (Nichols and others, 1986). North Bay is an area where complex interactions between human disturbance and natural processes affect the success of aquatic species. Suisun Bay, Carquinez Strait, and San Pablo Bay, which make up North Bay, are important nurseries for estuarine fish. More than 60 percent of the migratory water birds comprising the Pacific Flyway pass through the San Francisco Bay region during winter. The Suisun Bay/Delta may also be one of the U.S. estuaries most susceptible to pollution. Approximately 4 percent of the oil transported in the world is refined on its shores (Nichols and others, 1986). Some local refineries use Se- and V-rich petroleum from the San Joaquin Valley and their waste effluent is enriched in these elements compared to the concentrations found in natural waters (table 1).

\section{Selenium}

High selenium concentrations have been reported in the waters of Suisun Bay and Carquinez Strait as well a? in diving ducks (scoter and scaup) and in the clams that they eat (Cutter, 1989; Johns and others, 1988). Although agricultural drainage was a potential source, the highest concentrations in water and clams were found adjacent to oil refineries (fig. 1). The oxidation state of selenium in Suisun Bay. waters was also typical of that found in refinery effluent (dominated by Se (IV)). Mass balance calculations showed that refinery wastes could account for much of the selenium in these waters.

Dissolved, biologically available selenium in Suisun Bay was below the level expected to cause toxicity $\mathrm{C}^{-}$to bioaccumulate in clams. However, experimental studies showed that the Se (IV) coming from the refineries was accumulated efficiently by phytoplankton. Phytoplankton converted Se (IV) to organic selenium, which was ef iciently taken up by clams when they ate the phytoplankton (Luoma and others, 1992). Thus, the specific form of selenium in the refinery wastes led to an especially efficient transfer to clams. Experimental studies also showed that selen "um was highly toxic to birds and fish when they ingested the element in their food. The contaminated scoter and scaup in Suisun Bay eat clams. Adverse effects on reproduction in both birds and fish began when selenium in food approached 7-10 $\mu \mathrm{g} / \mathrm{g}$ (micrograms per gram). The highest concentration of selenium in clams from North Bay was $9 \mu \mathrm{g} / \mathrm{g}$; the $1 \mathrm{l} n \mathrm{~g}$ term average at the site closest to the refineries was $5.2 \mu \mathrm{g} / \mathrm{g}$. Concentrations in mussels (Mytilus edulis) in this a-ea were as high as $11.4 \mu \mathrm{g} / \mathrm{g}$ (Johns and others, 1988). Reproductive damage or other adverse effects in the local birds have been difficult to directly demonstrate, partly because the birds most threatened by selenium are migratory and nest in Canada. However, concentrations are similar to those tr at cause documented reproductive damage in several other species of birds.

\section{Vanadium}

Vanadium has not been well studied as a pollutant, but it is introduced into the environment as a contaminant in waste streams (table 1). Dissolved vanadium is toxic to aquatic organisms at high concentrations $(11.2 \mathrm{mg} / \mathrm{L}$ ) (Holdway and Sprague, 1979). The effect of transfer up the food web along with bioaccumulation, which is impotant for selenium, is unknown for vanadium. Vanadium behaves as an anion in estuaries; the most toxic form seems to be 


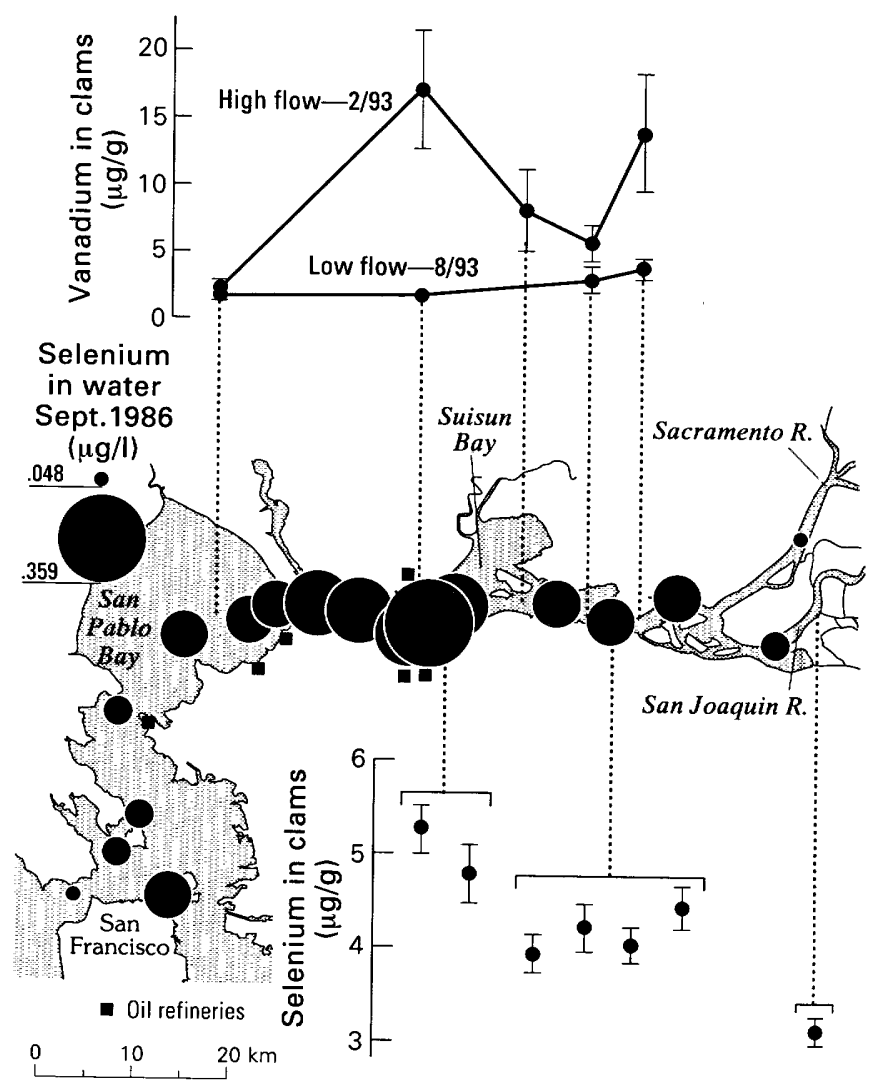

Figure 1 (Brown and Luoma). Comparison of vanadium (upper graph) and selenium (lower graph) concentrations in clams $\mu \mathrm{g} / \mathrm{g}$ dry weight), and total dissolved selenium $(\mu \mathrm{g} / \mathrm{L})$ (dark circles) in North San Francisco Bay, Calif. The vanadium concentrations in the upper graph were analyzed in the clam Potamocorbula amurensis, comparing periods of high river flow and low river flow in the bay (Brown and Luoma, unpub. data). The selenium concentrations in the lower graph were analyzed in the clam Corbicula fluminea (Johns and others, 1988). The dissolved selenium values are from Cutter (1989). Highest concentrations of selenium and vanadium in the clams and selenium in the water occur nearest the oil refineries. High vanadium values in the clams also occur near the mouth of the Sacramento and San Joaquin Rivers.

pentavalent vanadium (Holdway and Sprague, 1979). This would be a common species in oxygenated waters at the $\mathrm{pH}$ typical of San Francisco Bay (7.5-8.5). Fallout from the atmosphere would most likely be as pentavalent vanadium also (Holdway and Sprague, 1979).

Vanadium accumulates in clams in the North Bay. The highest concentrations (up to $17 \mu \mathrm{g} / \mathrm{g}$ ) occur nearest the oil refineries and upstream near the mouths of the Sacramento and San Joaquin Rivers (fig. 1). The lowest concentrations $(0.7-3 \mu \mathrm{g} / \mathrm{g})$ occur in clams away from energy-related sources. Vanadium bioaccumulation in clams will result in exposure to fish and birds.

The highest vanadium concentrations occurred during periods of high river flow (fig. 1). In addition to input from
Table 1 (Brown and Luoma). Typical selenium and vanadium concentrations $(\mu \mathrm{g} / \mathrm{L})$ in natural waters (oceans), local rivers, and San Francisco Bay, compared to average effluent from six local refineries.

[Selenium in the San Joaquin River represents local contamination from agricultural drainage. Source of vanadium in the Sacramento and San Joaquin R'vers may be natural from shales in the Central Valley and Fe-rich minerals from the Sier"a Nevadas, although oil fields occur in the San Joaquin drainage]

\begin{tabular}{lccccc}
\hline & Ocean & $\begin{array}{c}\text { Sacramento } \\
\text { River }\end{array}$ & $\begin{array}{c}\text { San Joaquin } \\
\text { River }\end{array}$ & $\begin{array}{c}\text { San Francisco } \\
\text { r } \text { *y }\end{array}$ & $\begin{array}{c}\text { Refinery } \\
\text { effluent }\end{array}$ \\
\hline $\mathrm{Se}^{2}$ & 0.10 & 0.08 & 1.17 & 0.22 & 127 \\
$\mathrm{~V}$ & ${ }^{3} 1.78$ & 43.93 & 46.87 & no data & 119 \\
\hline
\end{tabular}

\footnotetext{
${ }^{1}$ Annual waste reports 1993.

${ }^{2}$ Cutter, G.A., 1989, The estuarine behaviour of se'enium in San Francisco Bay: Estuarine, Coastal and Shelf Science, v. 28, p. 13-34.

${ }^{3}$ Collier, R.W., 1984, Particulate and dissolved vanadium in the North Pacific Ocean: Nature, v. 309, p. 441-444.

${ }^{4}$ Linstedt, K.D., and Kruger, P., 1970, Determination of vanadium in natural waters by neutron activation analysis: Analytical Chemistry, v. 42, no. 1, p. 113-115.
}

refinery wastes, global estimates require that 40 percent of the vanadium entering the environment comes from the atmosphere, primarily from the combustion of oil (Nriagu and Pacyna, 1988). Thus inputs of vanadium-enriched runoff could add to inputs from the wastes of loca' refineries. It is also possible that inputs from local rivers which drain $\mathrm{V}$ enriched shales and the San Joaquin oil fielts contribute to the increased concentrations in clams durin $\%$ the rainy season. Better understanding of vanadium dynamics in water and biota, as well as food web transfer and to ricity of the element, is necessary to determine its effects in San Francisco Bay.

\section{REFERENCES}

Cutter, G.A., 1989, The estuarine behaviour of selenium in San Francisco Bay: Estuarine, Coastal and She'f Science, v. 28, p. 13-34.

Holdway, D.A., and Sprague, J.B., 1979, Chronir toxicity of vanadium to flagfish: Water Research, v. 13, p. 975-910.

Johns, C.E., Luoma, S.N., and Elrod, V., 1988, Selenium accumulation in benthic bivalves and fine sediments of San Francisco Bay, the Sacramento-San Joaquin Delta, anc' selected tributaries: Estuarine, Coastal and Shelf Science, v. 27, p. 381-396.

Luoma, S.N., Johns, C., Fisher, N.S., Steinberg, N.A., Oremland, R.S., and Reinfelder, J.R., 1992, Determination of selenium bioavailability to a benthic bivalve from particulate and solute pathways: Environmental Science and Technology, v. 26, no. 3, p. 485-491.

Nichols, F.H., Cloern, J.E., Luoma, S.N., and Peterson, D.H., 1986, The modification of an estuary: Science, v. 231, p. 567-573.

Nriagu, J.O., and Pacyna, J.M., 1988, Quantitat"ve assessment of worldwide contamination of air, water and soils by trace metals: Nature, v. 333, p. 134-139. 


\section{Hydrogeology and Potential of Intrinsic Bioremediation at a Manufactured Gas Plant, Charleston, South Carolina}

\author{
Bruce G. Campbell, U.S. Geological Survey, \\ 1815 I'on St., Sullivan Island, SC 29482, and \\ Matthew D. Petkewich, James E. Landmeyer, \\ and Francis H. Chapelle, U.S. Geological Survey, \\ Stephenson Center, Suite 129, 720 Gracern Road, \\ Columbia, SC 29210-7651
}

\section{The Environmental Impact of Manufactured Gas Plants}

Manufactured gas plants (MGP's) have produced gas from coal or oil for residential and commercial fuel supply since the early 1800 's. Until the 1960 's, approximately 2,000 MGP's were in operation throughout the United States, when the use of pipelines was more effective to serve large areas with natural gas (Edison Electric Institute, 1984). Although not currently in operation, many of these MGP's have left behind a legacy of contaminated soil and ground water resulting from the disposal of byproduct materials generated during the gas-manufacturing process. These wastes include tar residues and sludges dominated by polynuclear aromatic hydrocarbons (PAH's), volatile organic hydrocarbons (VOC's), phenols, and inorganic heavy metals (Luthy and others, 1994). In many cases, the primary receptor for these contaminants has been the shallow water-table aquifer system beneath MGP's. Such contamination of the shallow aquifer is of concern, because these systems are either a source of potable water or they discharge to surface-water bodies. Additionally, many of the contaminants released to these aquifers are considered either known, probable, or possible human carcinogens by the U.S. Environmental Protection Agency (1994).

The possibility exists for reducing the level of concern raised by ground-water contamination beneath MGP sites by evaluating the potential of certain processes that retard the movement of contaminant hydrocarbons in shallow aquifers, namely adsorption by aquifer sediments and intrinsic bioremediation through degradation by natural subsurface microorganisms. Laboratory-derived adsorption coefficients and rates of microbial degradation, in combination with knowledge of the hydrogeology of the contaminated aquifer, can be applied in a framework recently developed by the U.S. Geological Survey (USGS) (Chapelle, Landmeyer, and P.M. Bradley, work in progress), based on solute-transport modeling using the 2-dimensional numerical model SUTRA (Voss, 1984). This approach will allow an evaluation of the effectiveness of intrinsic bioremediation at those sites where hydrocarbons have been released to the water-table aquifer.
To evaluate the effectiveness of intrinsic biormediation of shallow ground-water systems contaminat $: d$ with PAH, VOC, phenols, and heavy inorganic metals, a former MGP in Charleston, S.C., was investigated. The MGP was in operation from the 1850's to the 1950's. Management practices, which probably included on-site waste dispos?l, have created extensive soil and ground-water contamination at the former MGP site and downgradient at a 4-acre tract of land purchased by the National Park Service (NPS) in 1989 (Chester Environmental, 1994) (fig. 1). The City of Charleston plans to lease 1.5 acres of this land from the NPS to build the proposed South Carolina Aquarium.

\section{Field and Laboratory Methods of Evaluating Intrinsic Bioremediation Potential at MGP}

The most accurate method for quantifying rates of adsorption for a particular hydrocarbon contaminant is through laboratory adsorption isotherm experiments. An adsorption distribution coefficient, $\mathrm{K}_{\mathrm{ads}}$, of $4.84 \times 10^{-6}$ cubic feet per milligram $\left(\mathrm{ft}^{3} / \mathrm{mg}\right)$ was determined for naphthalene, the primary ground-water contaminant at the MGP site, for use in the solute-transport model (see next section).

A sensitive laboratory method for determining rates of microbial degradation involves radiotracer experiments with contaminated aquifer sediments. Shallow aquifer material collected near monitoring well USGS-1 (fig. 1) in ubated with ${ }^{14} \mathrm{C}$-naphthalene produced an aerobic, first-orde- degradation rate of 0.09 day $^{-1}\left(\mathrm{~d}^{-1}\right)$ and an anaerobic rate of $\leq 0.0001 \mathrm{~d}^{-1}$; and deeper aquifer material incubated $w^{\text {th }}{ }^{14} \mathrm{C}$ naphthalene produced an anaerobic, first-order rate of $\leq 0.001 \mathrm{~d}^{-1}$. Shallow aquifer material collected near monitoring well USGS-1 (fig. 1) incubated with ${ }^{14} \mathrm{C}$-tolue duced an aerobic, first-order degradation rate of $0.08 \mathrm{~d}^{-1}$ and an anaerobic rate of $\leq 0.0008 \mathrm{~d}^{-1}$; and deeper aquifer material incubated with ${ }^{14} \mathrm{C}$-toluene produced an anaerobic, firstorder rate of $\leq 0.0001 \mathrm{~d}^{-1}$. Aerobic bed sediments from the Cooper River (the ultimate shallow ground-water discharge area) incubated with ${ }^{14} \mathrm{C}$-toluene produced a first-order degradation rate of $0.08 \mathrm{~d}^{-1}$.

\section{Framework for Assessing the Potential of Intrinsic Bioremediation to Contain Contamination}

The transport of contaminants in ground w'ater is affected by hydrogeologic, geochemical, and microl inlogical processes. For hydrocarbons in ground water, these processes can be described by the following mass balance equation:

$$
\frac{\delta C}{\delta t}=D\left(\frac{\delta^{2} C}{\delta x^{2}}\right)-v \frac{\delta C}{\delta x}-k C-S C^{n}
$$




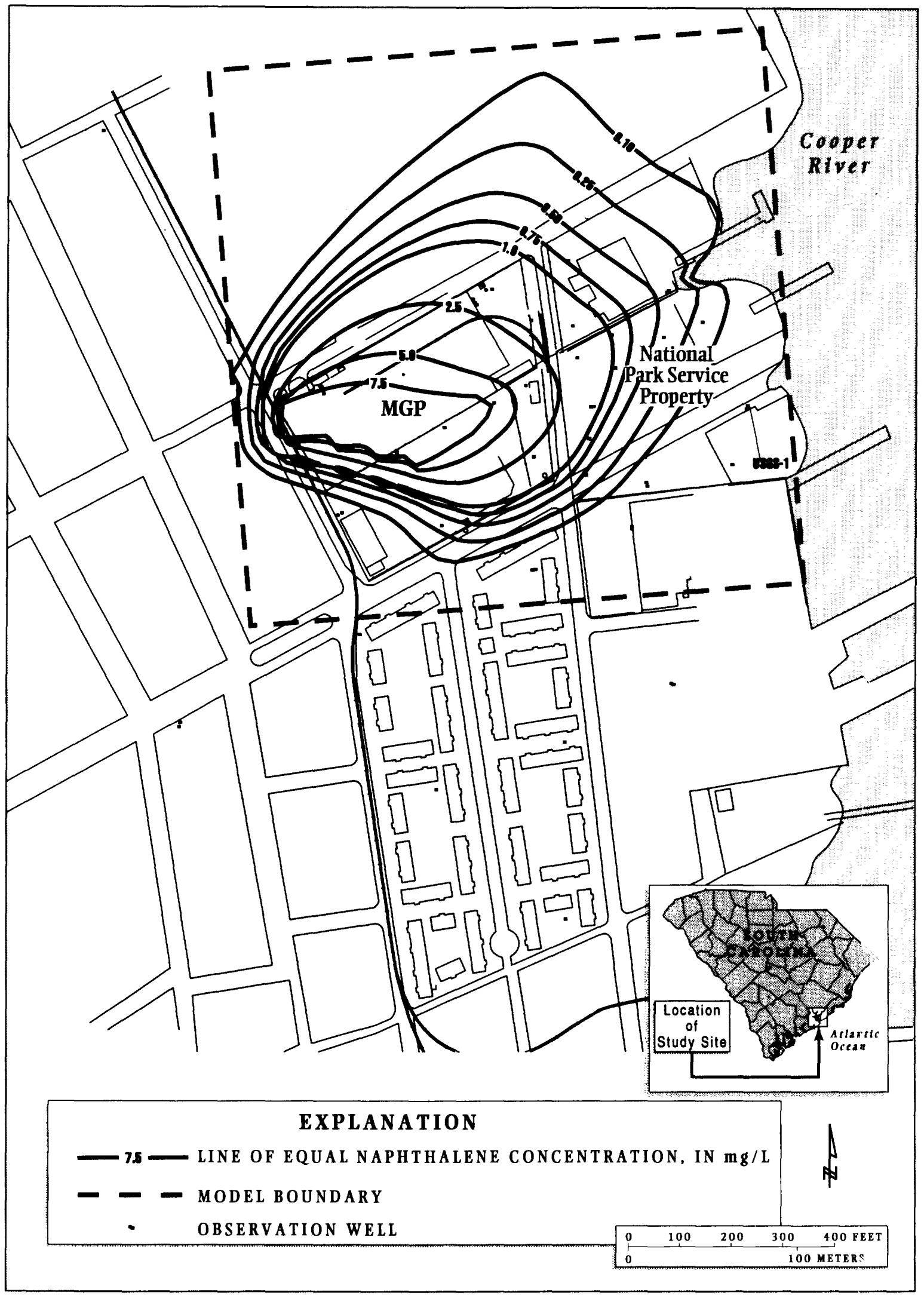

Figure 1 (Campbell and others). Simulation of the January 1994 naphthalene plume on the National Park Service property and on adjacent properties, Charleston, S.C. MGP, manufactured gas plant. 
where:

$C$ is the concentration of solute;

$t$ is the time;

$D$ is the coefficient of hydrodynamic dispersion;

$x$ is the distance;

$v$ is the velocity of ground-water flow;

$S$ and $n$ are the adsorption isotherm parameters; and,

$k$ is the first-order microbial degradation rate constant.

The primary processes that restrict the spread of hydrocarbons with moving ground water are adsorption and microbial degradation. If the rates of adsorption and degradation are fast relative to the rate of ground-water flow, then hydrocarbons will not be transported far from their source area. Conversely, if the rates of adsorption and microbial degradation are slow relative to ground-water flow, contaminants will be transported from the source area and may discharge at points of contact (POC) such as surface-water bodies. Equation 1 can be solved with finite-element numerical methods to predict concentrations of solutes at particular points in space (such as a POC) at various times.

For the MGP site in Charleston, S.C., equation 1 was solved numerically using the SUTRA code with field- and laboratory-derived rates of adsorption and microbial degradation to simulate the release of naphthalene at the site since the mid-1800's (fig. 1). The simulated plume geometry depicts the current steady-state distribution of naphthalene in the shallow aquifer system. Because the particular POC has been reached (discharge to the Cooper River), the numerical model framework can allow the range of naphthalene concentrations discharging to the Cooper River to be estimated.

\section{REFERENCES}

Chester Environmental, Inc., 1994, Preliminary site characterization summary, Calhoun Park Area Site RI/FS Charleston, South Carolina: Consulting report to South Carolina Electric and Gas Company, chapter 5.

Edison Electric Institute, 1984, Handbook on manufactured gas plant sites: ERT Project number P-D215, prepared for Utility Solid Waste Activities Group Superfund Committee, Washington, D.C.

Luthy, R.G., Dzombak, D.A., Peters, C.A., Roy, S.B., Ramaswami, A., Nakles, D.V., and Nott, B.R., 1994, Remediating tar-contaminated soils at manufactured gas plant sites: Environmental Science \& Technology, v. 28, no. 6, p. 266-275.

U.S. Environmental Protection Agency, Office of Water, 1994, Drinking water regulations and health advisory: EPA 822-R-94-001, 11 p.

Voss, C.I., 1984, A finite-element simulation model for saturatedunsaturated, fluid-density-dependent ground-water flow with energy transport or chemically-reactive single-species solute transport: U.S. Geological Survey Water-Resources Investigations Report 84-4369, 409 p.
The Effects of Oil-Field Brines on

Aquifers-Brine Disposal in the East Poplar Oil Field, Fort Peck Indian

Reservation, Northeastern Montana

Steven D. Craigg and Joanna N. Thamke,
U.S. Geological Survey, Helena, MT 59626

Introduction

The U.S. Geological Survey (USGS) currently is investigating the effects of disposal of oil-field brine on shallow ground water in Quaternary alluvial and glacial deposits in the East Poplar oil field, on the Fort Peck Indian Reservation, in northeastern Montana (fig. 1). The study, which is being conducted in cooperation with the Fort Peck Tribes Water Resources Office, began in October 1991 and is sche tuled to end in September 1994.

An earlier USGS study (Levings, 1984) documented the existence of brine contamination in shallow ground water along the Poplar River in this area. The present study not only expands on that work but also focuses on brine contamination in glacial till deposits east of the river. The general purpose of this study is to determine the extent, marnitude, and movement of brine in shallow ground water in the East Poplar oil field. Specific objectives are to (1) delineate areas of brine or saline water occurrence and its lateral and vertical extent in shallow ground water; (2) determine probable sources of the brine; (3) determine direction and, if possible, rate of brine movement; (4) determine chemical characteristics of the brine and shallow ground water; and (5) investigate possible effects of brine or saline grourd-water discharge on the quality of water in the Poplar Rive:-

\section{Location and Geographic Setting}

The East Poplar oil field study area is in the so "th-central part of the Fort Peck Indian Reservation, in northeastem Montana, a few miles north of the town of Poplar (fig. 1). The study area is traversed by the Poplar River. Land uses are dryland wheat farming, livestock grazing, and oil production. Shallow ground-water supplies are obtained both from alluvial deposits along the Poplar River and from glacial deposits in the uplands east of the river.

\section{Brief History of Oil-Production Activities}

Oil production began in 1952 from the Missirsippian Madison Group, at depths of about 5,500 to 6,000 fe t. Over the past 42 years, millions of barrels of brine (brine is defined by USGS as water containing greater thar 35,000 $\mathrm{mg} / \mathrm{L}$ (milligrams per liter) of dissolved solids) heve been produced with the oil. 
Brine disposal is by injection into shallower subsurface geologic units, mainly the Upper Cretaceous Judith River Formation, at depths of about 800 to 1,000 feet, and a Lower Cretaceous sandstone, at a depth of about 3,300 feet. Smaller quantities of brine have been directed to storage and evaporation pits. Limited attempts have been made to inject brine back into the producing zones for secondary recovery of oil, but at present (1994) no such activity is occurring.

\section{General Geology}

The study area lies along the western flank of the Williston Basin and generally consists of a broad, flat glacial bench that is dissected by the Poplar River valley. The lowermost formation that crops out is the Upper Cretaceous Bearpaw Shale, a dark-gray marine shale.

The Bearpaw Shale is overlain by Pleistocene glacial deposits (till) that generally attain a maximum thickness of about 100 to 150 feet. The glacial deposits mainly lie topographically above and to the east of the Poplar River, although less extensive exposures also are present to the west. The glacial till deposits generally consist of a heterogeneous mixture of rock particles ranging in size from clay to boulders. A Pleistocene unit, the Wiota Gravel, probably is present at the base of the till, but does not crop out.

Deposits of Quaternary (Holocene) alluvium are present in the Poplar River valley. Along the flanks of the valley, deposits of Pleistocene and Holocene fan alluvium and colluvium, along with thin deposits of dune sands, are exposed. Thickness of alluvium generally is about 50 feet. Alluvium mainly consists of silt, sand, and gravel from reworked glacial deposits.

\section{General Hydrogeology}

Shallow ground-water supplies are obtained from both the alluvial and glacial deposits. Wells completed in alluvium generally range from about 15 to 50 feet in depth. Wells completed in glacial deposits generally range from about 70 to 120 feet in depth.

In alluvium, direction of water movement generally is from north to south along the Poplar River valley, with local flow components toward the river. In glacial deposits, direction of water movement is not completely known; however, in the bench on the east side of the river, flow is generally southwest.

In some areas, handling, transport, and disposal of the brine have resulted in its movement into shallow ground water in both the Poplar River alluvium and the glacial deposits. Probable sources of the brine in the shallow ground-water systems are (1) leakage of water through breaches in disposal-well casing; (2) leakage of water through storage and evaporation pits that either were not adequately sealed initially or that have developed ruptures in the sealing material; and (3) leakage of wa+or from brinetransporting pipelines.

\section{Preliminary Results}

Field work for the project is complete. Data collection consisted of conducting electromagnetic surface-geophysical traverses; monitor-well drilling and completion; waterquality sampling of monitor wells, selected domestic wells, and brine-disposal wells; and obtaining streamflow and water-quality measurements along the Poplar River.

\section{Electromagnetic Surface Geophysirs and Monitor-Well Drilling}

Electromagnetic surface-geophysical methods were used to assist in delineating areas of brine or saline water occurrence and to assist in locating sites for drilling and completing monitor wells. Approximately 7,000 electromagnetic measurements were made during 1992 and 1993. Twenty-seven monitor wells have been completed; 19 wells are completed in alluvium and 8 in glacial deposits. For each well (with the exception of two nested $\mathbf{m}$ onitoring well sites), an attempt was made to bottom the hole in the Bearpaw Shale to obtain a total thickness for the deposit at that locality.

Two aquifer tests (one of alluvium using a pumped well and three observation wells, and one of glacial deposits using a pumped well and two observation wells) were conducted in 1993. The tests were conducted beyond salinity-plume areas to obtain data about ground-water flow directions and rates, and hydrologic characteristics of the deposits.

\section{Water-Quality Sampling of Wells}

Water-quality sampling is complete for all monitor wells, selected domestic wells, and brine-disposal wells. Wells were sampled for major and trace constituents. Dissolved-solids concentrations of the brine ate as much as $160,000 \mathrm{mg} / \mathrm{L}$, the major constituents bein $:$ chloride and sodium. In plume areas, dissolved-solids concentrations in shallow ground water are as much as $114,000 \mathrm{mg} / \mathrm{L}$, and the major constituents also are chloride and sodium. In nonplume areas, dissolved-solids concentrations in shallow ground water typically are less than $2,000 \mathrm{mg} / \mathrm{L}$, and the major constituents are bicarbonate and sodium.

\section{Streamflow and Water-Quality Measurements}

Four sets of streamflow and water-quality measurements were conducted along a 6-mile reacl of the Poplar River to determine gains or losses in flow and changes in water quality. In the first set of measurements, conducted during September 1981 (Levings, 1984), streamflow varied from $1.7 \mathrm{ft}^{3} / \mathrm{s}$ (cubic feet per second) upstream to $0.74 \mathrm{ft}^{3} / \mathrm{s}$ 

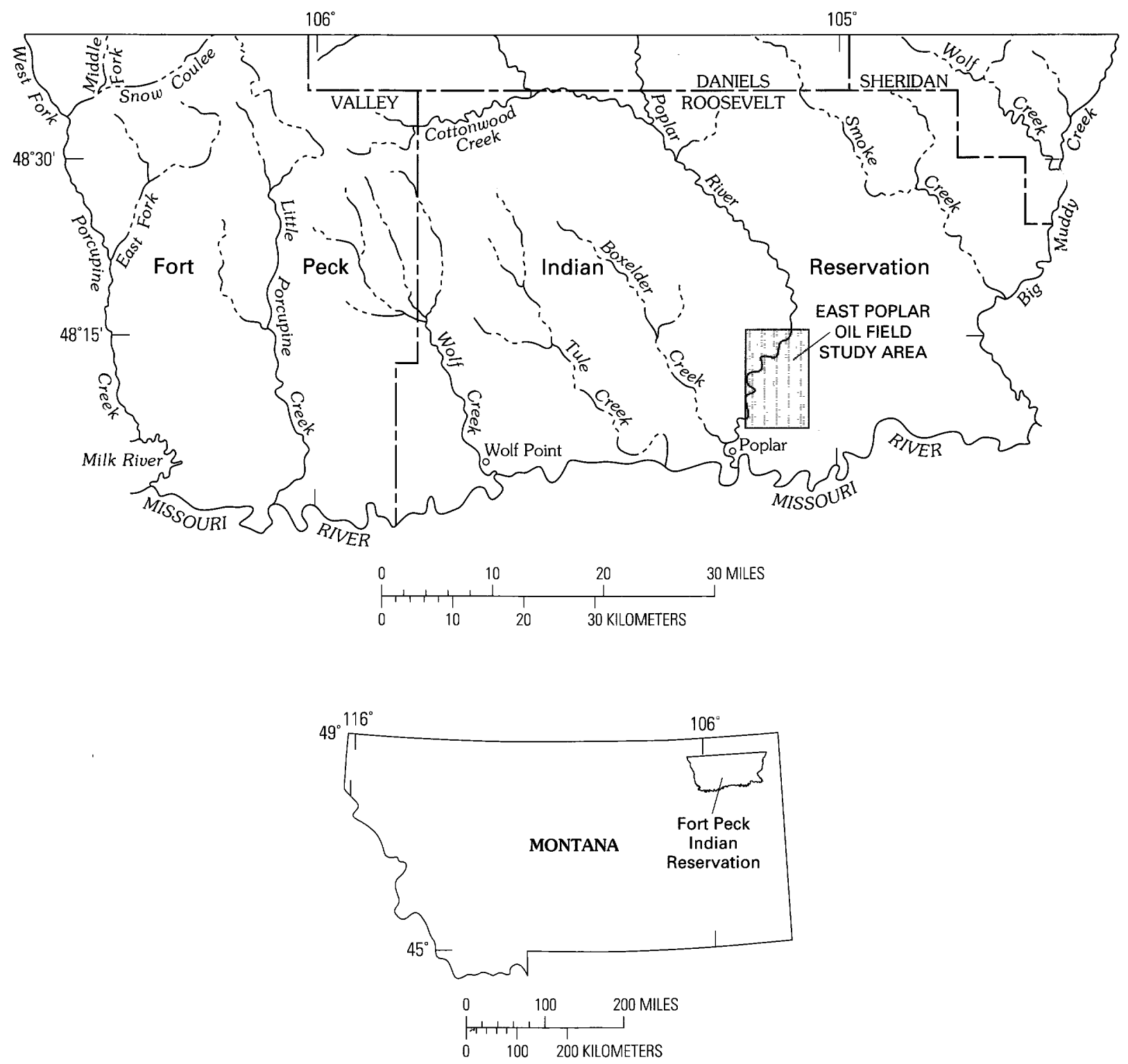

Figure 1 (Craigg and Thamke). Location of East Poplar oil field study area, northeastern Montana.

downstream; chloride concentration increased from 20 to $880 \mathrm{mg} / \mathrm{L}$. In the second set of measurements (conducted during April 1991), streamflow varied from 82 to $85 \mathrm{ft}^{3} / \mathrm{s}$; chloride concentration increased from 11 to $29 \mathrm{mg} / \mathrm{L}$. In the third set of measurements (conducted during July 1991), streamflow varied from 47 to $44 \mathrm{ft}^{3} / \mathrm{s}$; chloride concentration increased from 10 to $61 \mathrm{mg} / \mathrm{L}$. In the fourth set of measurements (conducted during September 1991), streamflow varied from 8 to $1 \mathrm{ft}^{3} / \mathrm{s}$; chloride concentration increased from 17 to $160 \mathrm{mg} / \mathrm{L}$.

\section{SELECTED REFERENCES}

Craigg, S.D., and Thamke, J.N., 1992, Overview of possible effects of brine disposal on shallow ground-water resources in the East
Poplar oil field, Fort Peck Indian Reservation, northeastern Montana [handout]: American Water Resources Ass xiation, Montana Section Meeting, Helena, Montana, September 17-18, 1992.

1993a, Hydrogeology of the Fort Peck Indian Res rvation, northeastern Montana: Geological Society of America, Cordilleran and Rocky Mountain Section Meeting, Reno, Nevada, May 19-21, 1993, Abstracts with Programs, p. A154.

1993b, Hydrogeologic aspects of brine disposal in the East Poplar oil field, Fort Peck Indian Reservation, northeastern Montana: Geological Society of America, Cordilleran and Rocky Mountain Section Meeting, Reno, Nevada, May 19-21, 1993, Abstracts with Programs, p. A25.

Levings, G.W., 1984, Reconnaissance evaluation of contamination in the alluvial aquifer in the East Poplar oil field, Roosevelt County, Montana: U.S. Geological Survey Water-Resources Investigations Report 84-4174, 29 p. 
Mendes, T.M., Thamke, J.N., and Craigg, S.D., 1992, Application of electromagnetic geophysical techniques to delineate salinewater plumes in shallow aquifers of the East Poplar oil field, Fort Peck Indian Reservation, northeastern Montana [handout]: American Water Resources Association, Montana Section Meeting, Helena, Montana, September 17-18, 1992.

Thamke, J.N., 1991, Reconnaissance of ground-water resources of the Fort Peck Indian Reservation, northeastern Montana: U.S. Geological Survey Water-Resources Investigations Report 914032, 2 sheets.

Thamke, J.N., Craigg, S.D., and Mendes, T.M., 1992, Changes in ground-water quality resulting from saline-water migration in a shallow glacial aquifer in the East Poplar oil field, Fort Peck Indian Reservation, northeastern Montana [handout]: American Water Resources Association, Montana Section Meeting, Helena, Montana, September 17-18, 1992.

1993, Use of electromagnetic geophysical techniques and auger drilling to delineate saline-water plumes in the East Poplar oil field, Fort Peck Indian Reservation, northeastern Montana [handout]: American Association of Petroleum Geologists, Rocky Mountain Section Meeting, Salt Lake City, Utah, September 12-15, 1993, Abstracts and Program, p. $67-68$.

\section{Potential Impact of Oil and Gas Drilling Operations on Carlsbad Caverns National Park, New Mexico}

\author{
Kimberley I. Cunningham and \\ G. Michael Reimer, U.S. Geological Survey, \\ Denver, CO 80225; Harvey R. DuChene, Axem \\ Resources, Inc., Denver, CO; Edward J. LaRock, \\ 4148 E. 19th Ave., Denver, CO ; and \\ Sandra L. Szarzi and Josh M. Been, \\ U.S. Geological Survey, Denver, CO
}

Studies of rock fracture and jointing trends, combined with gas geochemistry techniques, have provided some preliminary tools for evaluating the potential impact of oil and gas drilling operations on Lechuguilla Cave, Carlsbad Caverns National Park, New Mexico. Lechuguilla Cave is now widely held to be the world's finest speleological resource and is considered by many experts to be a veritable treasure-trove of underground scientific research opportunities. In addition to containing more elemental sulfur and secondary gypsum than all other known limestone caves in the world combined, Lechuguilla possesses an array of new speleothem types, curious mineralogic associations, and a unique bacterial and fungal microflora that is a focus of cancer research and of NASA-sponsored exobiological (the study of extraterrestrial organisms) research.
The question of whether or not high-permeability pathways exist between the extensive rassageways of Lechuguilla (more than $120 \mathrm{~km}$ of passage have been mapped since 1986) and prospective oil and gas drilling sites (located less than $1.25 \mathrm{~km}$ north of the cave on Bureau of Land Management property) was addressed by investigating the relationships between roc' fracture/jointing trends and cave parameters (location, amount of passage, and predominant trend of passages), and by tracergas experiments. Lineaments and curvilin saments (structurally controlled straight or curving lines visible on aerial photographs) were interpreted from satellite and high-altitude aircraft imagery and plotted with the cave data at a scale of $1: 24,000$. For most caves, and particularly for Lechuguilla, more than 90 percert of the known cave passageways spatially coincide with the trend of the photolinears. Statistically significant trends were also documented from fractures and joints mapped from outcropping rock pavements, and from microscopic examination of rock thin sections. The results indicate that preexisting structural features exerted a strong influence on sites of cave development. Every cave in the area appears to be associated with a lineament, but not every lineament can be shown to be associated with a cave, although the probability of coincidence is high. Previously drilled gas wells that occur on interpreted lineaments exl thit a uniform high frequency of lost fluid circulation within the $650-\mathrm{m}$ thick cavernous rock package (fig. $1 ;$ p. 100-101). Most of these zones of fluid loss directly correlate to discrete levels of passage development in Lechuguille. Cave. In 1990 a large passage was discovered in Lechuguilla that extends along a mapped, northwest-oriented linearent toward the area of the BLM-managed drill sites. Aprroximately 8.5 $\mathrm{m}^{3}$ of helium gas was released in the cave near the new passage and more than 401 -m-deep soil-gas probes were installed on the surface at lineament inters sctions in order to detect helium migrating out of the cave system. Approximately 90 days after the initial gas release, significant amounts of helium were recovered from a probe placed directly on the northwest-trending lineament and $150 \mathrm{~m}$ from the Sidewinder gas well. The helium had moved to the recovery site at nearly $2 \mathrm{~cm} / \mathrm{min}$, a rate slightly greater than that of normal helium diffusion. The data do not provide any information on the size of the gastransmitting cave passage but do confirm that a permeable pathway exists between the two sites. Future work should focus on refining photolineament interpretations, accumulating additional ground-truth for mapped lineaments, and monitoring the ambient cave environment in order to detect the possible introduction of drilling contaminants, and to a greater degree, the presence of common constituents in the produced gas, specifically methane and hydrogen sulfide. 
State Coal Resources and ExtractionImpacts on the Economy and Environment

American Association of State Geologists

(Prepared by Heinz H. Damberger, Illinois State Geological Survey, 615 E. Peabody Drive, Champaign, IL 61820-6964)

By providing reliable, detailed information on coal resources, the geological surveys of the coal-producing States help government and industry plan for a healthy environment and prosperous economy. The information collected and made available by the State surveys is also widely used by Federal agencies. Many projects for developing needed information are therefore co-funded by the Federal Government and the States.

The following kinds of information are generated and made available by the State geological surveys:

- Coal resources, reserves, and availability for future development. Information is provided about location, depth, thickness, degree of assurance of existence, and minability and availability (surface versus deep, geologic character of associated strata, land-use restrictions, and conflicts with development of other resources).

-Coal quality relative to the various uses of coal. Representative channel, run-of-mine, and as-shipped samples are collected and analyzed for their chemical, physical, and technological properties, permitting evaluation of a coal for its various uses, in particular combustion and conversion to coke, liquids, and gases.

-Impact of coal mining and utilization. Information on past and current coal mining and utilization is collected and analyzed to assess the impact on the State's economy and physical environment.

\section{Coal Resources and Availability Studies}

A significant portion of the country's very large coal resources may be unavailable or significantly constrained for future development because of competing uses of land for towns, cemeteries, roads, railroads, airports, power lines, pipelines, oil and gas wells, streams, lakes, reservoirs, national and State forests, parks, and other recreation areas. Future resource development could also be significantly constrained by geologic and technological factors such as coal depth and thickness, lateral and vertical proximity to abandoned mines, barrier pillars, and problems related to roof and floor characteristics and geologic structure; or by a coal composition that precludes its use due to environmental hazards created by its use. At present, most of these constraints are largely unaccounted for in the existing coal resource and reserve databases that are used for projecting the future availability of coal. Previous statewide and national coal resource assessments ignored most $c^{f}$ these factors, in part because they are difficult to evaluate regionally or because sufficient information was lacking. Assessing their impact requires detailed study of local conditions.

The coal availability program that is jointly being undertaken by the Federal and State geological surveys answers these concerns. Representative sample areas the size of 7.5-minute quadrangles (about 56 square milss each) are being studied in detail for factors that limit the availability of the coal resources for future development.

So far, 30 quadrangles have been studied in the Appalachian and Illinois Basin coal fields, and initial concerns about the availability of coal resources have proven jistified: about 50 percent of the original resources were fourd to be unavailable for future development on these quadrargles.

The U.S. Bureau of Mines has cooperated with the U.S. Geological Survey and the State surveys to assess the recoverability of the available coal resources on the studie 1 quadrangles. By the end of FY94, study of 12 quadrangles had been completed, 11 from the central Appalachian and 1 from the Illinois Basin coal fields. The study concluded that, overall, only about 7 percent of the original id ntified resources may be economically minable and saleable in today's market; for the one quadrangle in Illinois, that portion was only 4 percent.

\section{Coal Quality for Various End Uses of Coal}

The State geological surveys have accumulated large quantities of data on the coal quality of the resources of their States; these are made available to the public, gove'nment, and coal mining and utilizing industries. In the past several decades, the U.S. Geological Survey, through the I'ational Coal Resource Data System (NCRDS) program, ras supported the collection and analysis of representative coal samples by the State geological surveys and has thus helped make these databases much more comprehensive tran they otherwise would be.

Increasingly, the data are being requested ant made available in electronic form. For example, the Indiana Geological Survey recently released a new type of publication on floppy disks (Computer Database \#1) that contains a comprehensive collection of the survey's coal analyses, permitting users to conduct their own searches and evaluations of the data. In 1985, the Illinois State Geologinal Survey (ISGS) created a computer-based "Information System on Chemistry of Coal in Illinois." This database, ac essible from remote stations by modem, allowed searches simple statistical analyses, and downloading of whatever data had been selected. Users were also given the option to have the ISGS conduct customized searches and either electronically transfer the data or prepare printouts. (The syster is currently inactive, due to a switch in hardware and soft"rare.) 


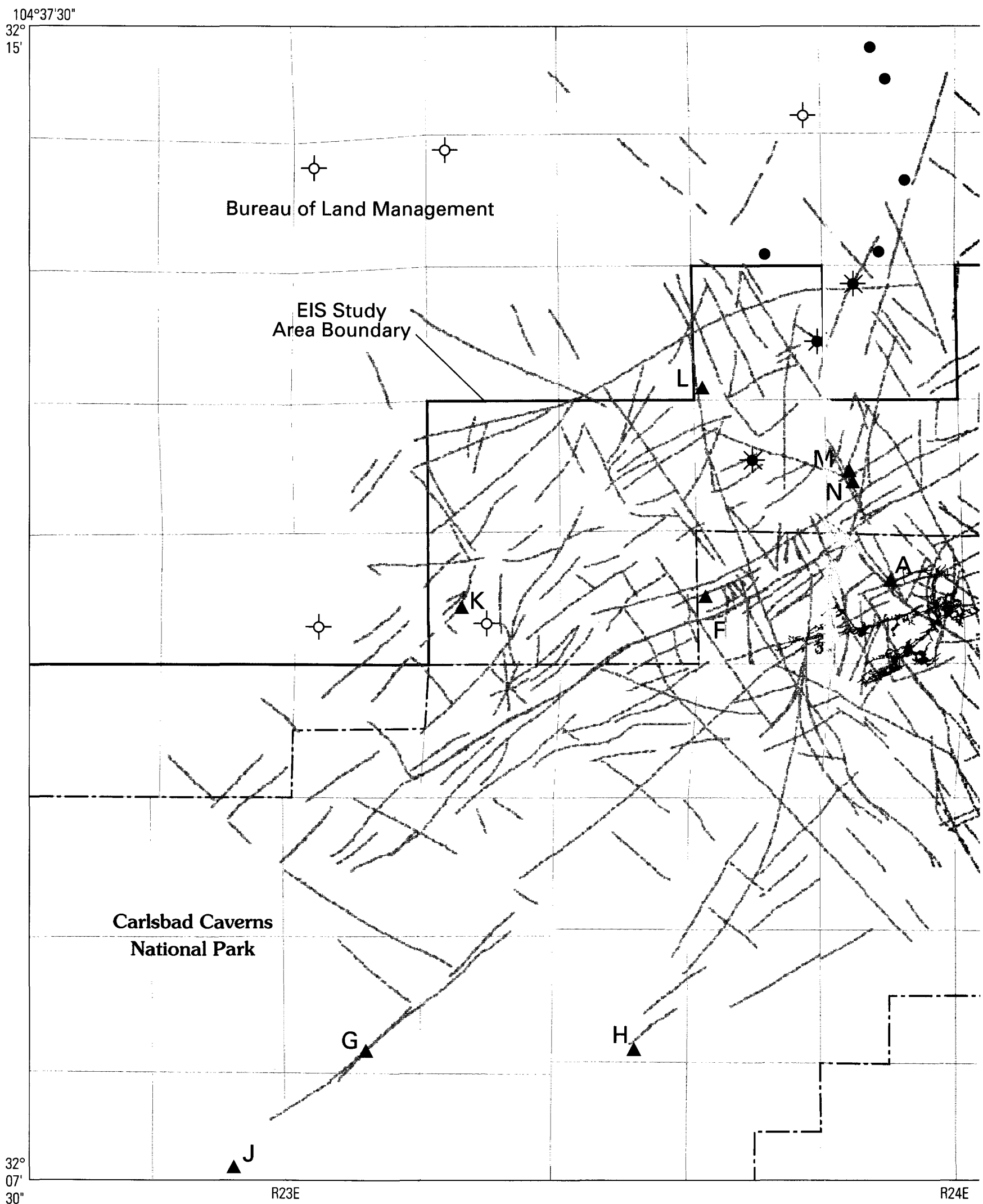

Figure 1 (Cunningham and others). Map showing relationships between interpreted photolineaments, gas wells (with and without frequent lost circulation zones), and caves in Carlsbad Caverns National Park area, New Mexico. Caves identified by small triangles: A, Lechuguilla Cave (approximately $120 \mathrm{~km}$ of passage known); B, Carlsbad Cavern; C, Spider Cave; D, unnamed cave; E, Chimney Cave; F, 


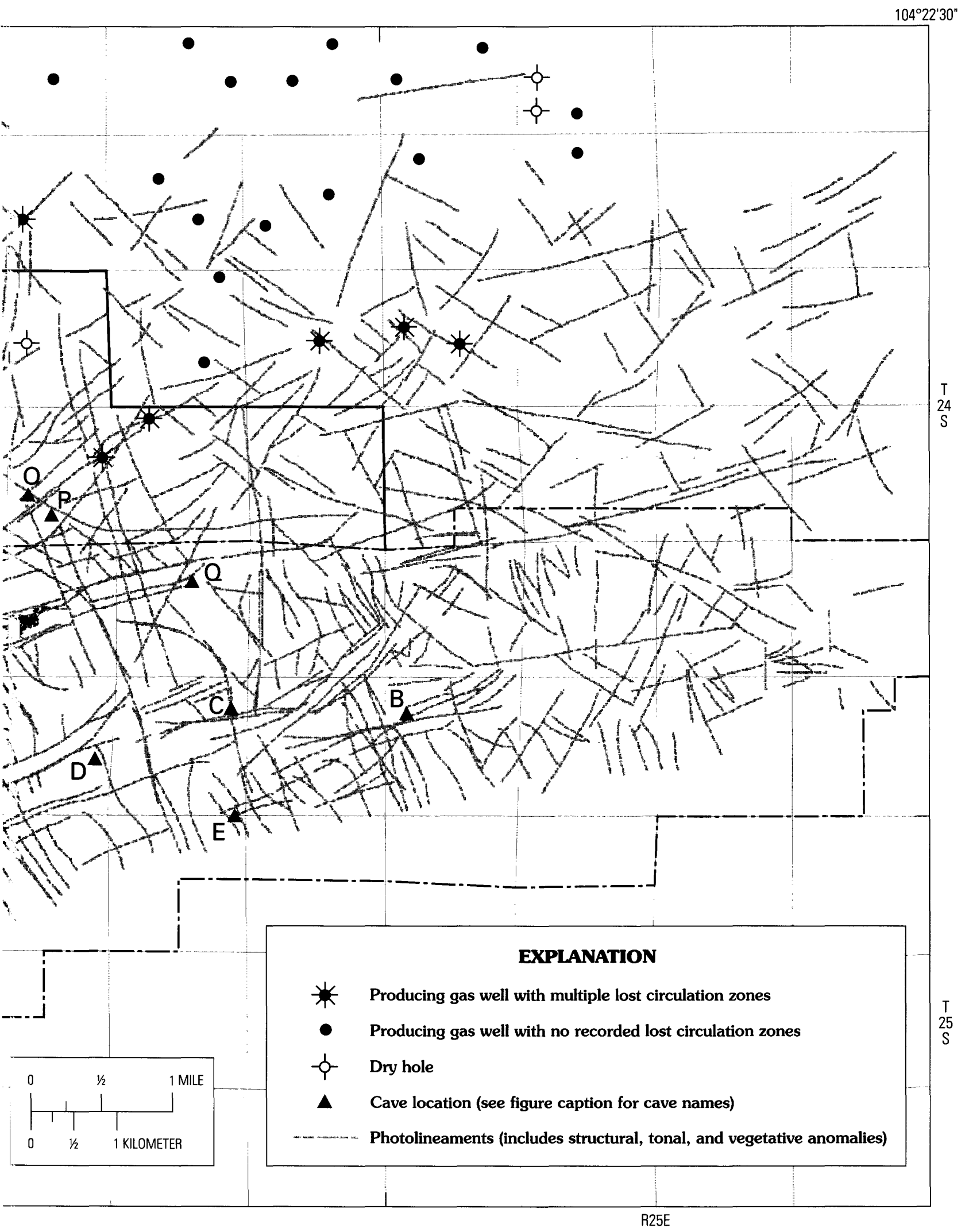

'Tarvestman Cave; G, Goat Cave; H, Wind Tunnel Cave; J, Whistling Cave; K, Serpentine Sinks Cave; L, Snake Trap Cave; M, Mudgett's ave; N, Little Mudgett's Cave; O, Little Manhole Cave; P, Big Manhole Cave; Q, Cueva de Leon. Digital line survey data for Lechuilla Cave provided by the National Park Service and the Lechuguilla Cave Project, Inc. 
The Illinois Basin Consortium, formed by the Illinois, Indiana, Kentucky, and U.S. Geological Surveys, has agreed to cooperate on the development of a comprehensive, basinwide atlas of the coal resources of the most important coal seams in the basin. The atlas will emphasize coal quality, in particular, amounts of sulfur and trace elements identified as hazardous air pollutants (HAPs) in the 1990 Amendments to the Clean Air Act. The project is attracting support by the coal mining and utilizing industries.

\section{Impact of Coal Mining and Utilization}

Many State geological surveys compile maps that show areas affected by mining. Because of the potential for mine subsidence, areas that have been undermined by underground mining are of particular interest. Planners, individual citizens, and insurance companies have great interest in such information. For example, the ISGS completed a study for the Illinois Mine Subsidence Insurance Fund of the potential of mine subsidence in urbanized areas. The ISGS also directed a multi-year, cooperative research program on mine subsidence in Illinois that was jointly supported by the State, the mining industry, and the Federal Government through the U.S. Bureau of Mines (USBM). Researchers from several universities, State agencies, and the USBM participated in the program. The program greatly increased the understanding of mine subsidence and its effects on the surface and subsurface, as well as the public's awareness of the issues associated with mine subsidence.

\section{Environmental Aspects of Carbonate Use in Energy Generation}

\author{
Jane R. Eggleston and Robert B. Finkelman, \\ U.S. Geological Survey, Reston, VA 22092
}

To meet the requirements of the Federal Clean Air Act of 1970 and the Amendments of 1977 and 1990, coal-burning power plants will use large tonnages of carbonate rock (limestone and dolomite) and lime for flue-gas desulfurization, fluidized bed combustion, and other processes designed to minimize air pollution. Environmentally compatible and cost-effective use of limestone resources depends on a good understanding of the quantity, quality, and proximity of limestone resources to coal-burning power plants. The properties of carbonates needed in coal-burning power plants vary with the type of desulfurization process used (Drehmel and Harvey, 1974). Dry-limestone-injection processes require carbonates with larger surface areas (fine grained) and a minimum of inert chemical impurities. Wet-limestone-scrubbing processes require carbonates with high dissolution rates. Chemically active fluidized beds require carbonates that are reactive with $\mathrm{SO}_{2}$ and $\mathrm{H}_{2} \mathrm{~S}$; usually dolomite is a good choice. Pilot studies are being conducted by various research facilities to further understand and define the properties that cause some limestones to be more effective in desulfurization processes.

Adequate carbonate resources must be available to meet the increased demands of new and proposed desulfurization facilities. A study is currently underr'ay at the USGS to identify limestone resources in the Easten United States that could be suitable for desulfurization in combustion systems. Carbonate resources are being identified, quantified, and characterized based on their sorbent properties and proximity to potential markets.

Another important parameter to consider in the desulfurization process is the trace-element contert. of the carbonate. Potentially hazardous trace elements in carbonates, such as arsenic, antimony, selenium, and lead, add to disposal problems for the highly alkaline wastes produced by fluidized bed combustors and in wet and dry flue gas desulfurization systems. Meij (1989), in studying a 600-megawatt coalfired power plant equipped with a wet flue-gas desulfurization (FGD) system, determined that most of the trace elements introduced into the FGD plant were atributable to the limestone.

Coal combustion is already well knowr as an important anthropogenic source of trace elements in the environment. The USGS has developed a large coal quality database, within the National Coal Resource Data Sy:tem (Bragg and others, 1994). Research on the distribution and modes of occurrence of trace elements in coal has been considerable (Swaine, 1990). Nevertheless, more informa tion is necessary to develop reliable models for predicting the behavior of these elements during coal combustion.

Data on the content and modes of ocrurrence of trace elements in both coal and limestone must $1 \cdot$ used to assess future environmental problems. The behavior of trace elements from both coal and limestone during various combustion processes will ultimately affect their potential for release into the environment either as emiss in or as leached products into ground water from waste: FGD waste (sludge) generation has increased steadily in the past 20 years and is estimated to reach 50 million tons per year by the year 2000 (fig. 1). A USGS project is aimed at identifying the trace elements present in sludge ard their behavior during combustion and scrubbing. In this roject, representative samples of limestone and coal scrubber sludge, and leached effluent from the sludge, will be collected from an active coal-fired facility. These samples will be analyzed for trace elements to trace the fate of specific elements through the process.

\section{REFERENCES}

Bragg, L.J., Oman, J.K., Tewalt, S.J., Oman, C.L., Rega, N.H., Washington, P.M., and Finkelman, F.B., 1994, U.S. 


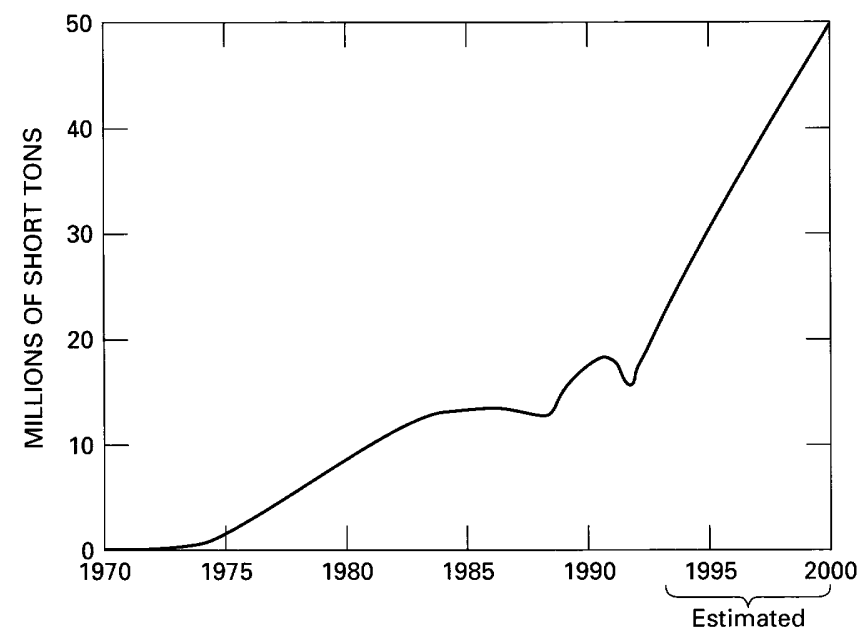

Figure 1 (Eggleston and Finkelman). Past and estimated future U.S. FGD sludge generation, 1970-2000 (modified from EPA, 1988, with 1985-1992 data from the American Coal Ash Association).

Geological Survey Coal Quality (COALQUAL) Database: Version 1.3, USGS Open-File Report 94-205, CD-ROM.

Drehmel, D.C., and Harvey, R.D., 1974, Carbonate rock properties required by desulfurization processes, in Tenth Forum on $\mathrm{Ge}$ ology of Industrial Minerals Proceedings: Ohio Division of Geological Survey Miscellaneous Report No. 1, p. 59-66.

Environmental Protection Agency, 1988, Wastes from the combustion of coal by electric utility power plants: Environmental Protection Agency Report to Congress, EPA/530-SW-88-002.

Meij, Ruud, 1989, Tracking trace elements at a coal-fired power plant equipped with a wet flue-gas desulphurisation facility: Kema Scientific and Technical Reports, The Netherlands, v. 7, no. 5, Special Issue, p. 267-355.

Swaine, D. J., 1990, Trace elements in coal: London, Butterworths, 278 p.

\section{Multi-Criterion Decision Analysis for Comparing Hydropower and Environmental Impacts from Operation of Glen Canyon Dam, Northernmost Arizona}

\author{
Dr. Marshall Flug, \\ River Systems Management Section, \\ Midcontinent Ecological Science Center, \\ National Biological Survey, 4512 McMurry \\ Avenue, Ft. Collins, CO 80525-3400
}

\section{Colorado River History}

The Colorado River provides a variety of beneficial uses that include hydroelectric power, irrigation water, flood control, lake and river recreation, and water for domestic and industrial use in seven Western States-Wyoming, Colorado, Utah, Arizona, New Mexico, Nevada, and California. In 1956 passage of the Colorado River Storage Project Act authorized construction of Glen Canyon Dam formirg Lake Powell. This Act also directed the Secretary of Intorior to plan and operate recreational facilities, to conserve scenery, archaeological objects, and wildlife, and to mitigate losses of fish and wildlife.

The "energy crisis" of the 1970's provided the impetus for a new wave of geologic and hydrologic research concerning the availability of water for uranium, tar sands, $0: 1$ shale, and synthetic fuels industries (US DOI, 1974; Hansen, 1975; Flug, 1979; Flug and others, 1979). As environmental awareness increased from the 1960 's, it was accompanied by changing societal values for resource preservation. "?his led to the Federal Government passing the Grand Canyon Protection Act in 1992, which includes the downstream resources in the Grand Canyon as primary purpose: of the Colorado River Storage Project Act of 1956. Other environmental legislation influencing river management includes the Endangered Species Act of 1973; Wild and Scenic Rivers Act of 1968; and the National Environmental Policy Act (NEPA) of 1969, which stipulates the requirements for preparing environmental impact statements (EIS).

With the completion of Glen Canyon Dam in 19<3, regulated flow releases for peak load hydropower alteret riparian conditions in the Grand Canyon forever. The cold, clear water releases helped establish a Blue Ribbon Trout Fishery (trout are non-native), in the river section below th $\%$ dam. The abundance of fish and the clear water attract eagles, which then prey on the readily accessible food source. As with any post-dam era, the clear water releases also disrupt the sediment balance, stream morphology, and sand bar formation. In 1982 the Glen Canyon Environmental Studies research effort was authorized to investigate whethe- and to what extent dam operations were damaging the Grand Canyon river corridor. Preliminary results documented the existence of damage, and in 1988 an Environmental Impact Statement was called for (BOR, 1993).

\section{Multi-Criterion Decision Analysis}

Management of water resources systems is complicated by an array of non-commensurable objectives (that is, resource values) that are advocated by diverse special interest groups. Multi-criterion decision analysis (MCDA) methods combine quantitative and qualitative objectives having different units of measure. My poster presentation ard interactive personal computer program demonstrate the application of multi-criterion decision analysis as an interactive means to enhance conflict resolution while including diverse but influential inputs. MCDA methods can enrich t $:$ management of water resources by providing a framework to help water managers identify critical issues, attach relative 
priorities to those issues, and determine the best potential compromise alternatives for consideration.

The value-based MCDA method used in this study was presented by Flug and Ahmed (1990), with a framework for general application given by Fontane and Flug (1991), and is based on the weighted average method as described in Goicoechea and others (1982). This method requires a "rating" value be determined for every specific decision criterion (attribute), in response to each flow alternative. A standard quantitative rating scale (for example, 1 to 5 ) is used for all resource criteria, with the larger value representing the more preferred condition. Generally, several related attributes are grouped together, and each contributes a fraction of the total score for a given resource value (or objective). The assignment of rating values should be based on a rating scheme provided by an expert who knows the attribute of concern and how it is impacted by the specific water resources system. The ratings for each attribute for all alternatives form an impact analysis matrix.

The values for each resource in the impact analysis matrix can be weighted by the relative importance assigned by any of several users or special interest groups. This feature provides the real framework for conflict resolution and tradeoff analysis. The relative importance (priority) of every objective is used to derive resource value weights. A most preferred resource is assigned the highest relative priority value. After scaling these priorities by dividing by the sum total of all priority values, a set of priority weights exists that will total to 1 . Then, the sum of the resource weights multiplied by the ratings for each objective for a specific alternative yields a weighted average score for that alternative. The alternative with the largest score identifies the most preferred flow alternative, based on the weights assigned by the special interest group.

\section{MCDA Application to Glen Canyon Dam}

The draft EIS identifies nine flow alternatives that are then used to evaluate the effects on an array of resource values. In brief, the nine flow alternatives include:

- two "Unrestricted Flows": the No Action, which maintains current historical dam operation; and Maximum Power Plant Capacity, which makes full use of the hydropower plant;

- four "Restricted Fluctuating Flows": including a High; Moderate; Modified Low; and Interim Low flow alternative, all of which incorporate varying reductions and restrictions in the daily fluctuations on flow releases; and

- three "Steady Flows": the Existing Monthly Volume, releasing historic flow volumes; the Seasonally Adjusted alternative designed to enhance downstream fish protection; and a Year Round steady flow which virtually eliminates any fluctuations.
A list of the seven impacted resource categories evaluated in this MCDA analysis was extracted directly from the draft EIS. Within each resource category, cne or more specific attributes (such as species or type of recreation activity) are enumerated and evaluated, and provide a fraction of the total resource value rating. From both qualitative and quantitative information provided in the EIS, a rating value system score from 1 to 5 was developed for each attribute, thereby producing the impact analysis matrix.

\section{RESOURCE OBJECTIVES:}

Fish

Vegetation

Wildlife and habitat

Endangered and special status species

Cultural resources

Recreation

Power

For each of these seven resource objectives relative priorities were identified by each of four specia' interest groups with expected conflicts over scheduled Colorado River flow releases from Glen Canyon Dam. The fou- special interest groups are: fishing enthusiasts; recreatione' rafters; proponents of hydroelectric power generation; and environmentally conscious individuals. In the final anal' 'sis a set of flow alternatives is selected that satisfies most ne :ds of all special interest groups.

\section{REFERENCES}

Bureau of Reclamation, 1993, Operation of Glen Canyon Dam-Draft Environmental Impact Statemønt: U.S. Department of the Interior, Government Printing $C$ ffice, 324 p.

Flug, Marshall, and Ahmed, Jahved, 1990, Prioritizing flow alternatives for social objectives: Journal of Water Resources Planning and Management, ASCE, v. 116, no. 5, p. 610-624.

Flug, Marshall, Walker, Wynn, and Skogerboe, G.V., 1979, Energy-water-salinity-Upper Colorado River basin: Journal of the Water Resources Planning \& Management Division, ASCE, v. 105, no. WR2, p. 305-315.

Fontane, D.G., and Flug, Marshall, 1991, Introduction to multi-criterion methods and selected software, in Anderson, J.L., ed., Proceedings of the 18th Annual Conference \& Symposium, Water Resources Planning \& Management and Urban Water Resources: American Society of Civil Engiveers, p. 449-453.

Goicoechea, Ambrose, Hansen, D.R., and Duckstein, Lucien, 1982, Multi-objective decision analysis with engineering and business applications: New York, John Wiley, 519 p.

Hansen, D.C., 1975, Water available for energy-Upper Colorado River basin: ASCE, Paper Preprint 2564, 12 p.

U.S. Department of the Interior, Water for Energy Management Team, 1974, Report on water for energy in the Upper Colorado River basin: Washington, D.C., U.S. Government Printing Office, $71 \mathrm{p}$. 


\section{Reclaiming the Scars of Energy's Past-Examples from the National Park Service}

\section{Bruce Heise, National Park Service, P.O. Box 25287, Denver, CO 80225}

European explorers and settlers were astounded by the North American continent's bounty of natural resources. The westward expansion of the young United States was driven by the desire to capitalize on these assets. The allure of mineral wealth in particular sustained a steady stream of westward movement, punctuated by periods of frenzied migration as new mineral deposits were discovered. By the end of the 19th century, the Federal Government was aggressively encouraging development of public land. By the middle of the 20th century, the United States, through its abundant energy resources, had emerged as a world leader in industrial capability and standard of living.

The extraction and consumption of the energy needed for such a rapid ascension took a toll on the Nation's environment. As coal, oil, and mineral deposits were depleted, their sites were quickly abandoned. Shafts, tipples, pits, derricks, even entire towns were deserted and forgotten. Piles of tailings, waste, and debris littered the landscape. In places, water, soil, vegetation, and wildlife habitat were seriously impacted.

Many of these sites, located in spectacularly scenic areas or having great biological, geological, or historical significance, were ultimately incorporated into the National Park system. Abandoned coal mines in the East, old gold, uranium, or lead mines in the West, and deserted oil and gas facilities along the Gulf Coast again experienced human activity, this time by a public interested in recreational or educational opportunities.

The Mining and Minerals Branch of the National Park Service, working cooperatively with individual parks, other Federal and State agencies, and the private sector, has initiated a program to rehabilitate lands disturbed by past energy development. More than 400 abandoned uranium and coal mine sites and more than 700 abandoned oil and gas wells can be found in units of the National Park system. Some energy development sites in parks have been restored as closely as possible to their native state. Some sites that remain abandoned continue to affect the surrounding area.

In determining how best to handle an abandoned site, a balance must be struck among park resource protection, visitor safety, and interpretive significance. For example, a mining site closed for public safety may yet remain accessible by a colony of endangered bats. Some sites are interpreted to explain their historical significance. Other parks use abandoned mines and wells as an opportunity to educate visitors about the importance of energy development and its impacts on our society.

\section{Oil Spills in Prince William Sound, Alarka}

\author{
Keith A. Kvenvolden and Paul R. Carlson, \\ U.S. Geological Survey, Menlo Park, CA 94025
}

On March 24, 1989, the Exxon Valdez supertanker grounded on Bligh Reef in Prince William Sound (fig. 1), spilling $\approx 11$ million gallons of North Slope crude oil. This oil spread quickly from the stricken vessel through the westem part of the sound and into the Gulf of Alaska (Galt and others, 1991). Along the southward trajectory of the spill, $\approx 16$ percent of the sandy, gravelly, and rocky shorelines of the sound were coated with oily residues. Cleanup operations and natural processes have now removed mu $h$ of the oil from the affected shorelines.

As part of a series of studies to determine the gachemical fate of the spilled oil, we have studied the hyd ocarbon distribution and carbon isotopic compositions of oil residues collected from beaches throughout the sound starting in 1990. By 1992 we had made two discoveries. First, six samples of weathered oil residues correlated, on the bas's of carbon isotopic composition and other geochemical parameters such as hopane and sterane biomarkers and polycyclic aromatic hydrocarbons, with the oil carried by the Exxon Valdez supertanker at the time of the spill. The carbon isotonic composition of this spilled oil measured $-29.2 \%$ o relati 'e to the PDB standard. Second, two additional samples of residues were chemically and isotopically distinct from the other six samples. Detailed geochemical analyses and comparisons indicated that these non-Exxon Valdez residues like'y originated from oils from the Monterey Formation (Miorene and Pliocene) of California and are residues of spilled oil products that had previously been shipped by barge to Alaska (Kvenvolden, Hostettler, and others, 1993).

The two samples of non-Exxon Valdez residues were collected from Storey Island and Elrington Island, at localities $\approx 100 \mathrm{~km}$ apart near the north and south ends of the sound (fig. 1). The geographic positions and almost identical carbon isotopic values of -23.8 and $-23.9 \%$ o suggested that we could expect to find residues of similar carbon isoto ic composition on the beaches throughout the sound. This expectation has been realized in that we have now obtained analyses for 48 samples of non-Exxon Valdez residues from many places in the sound (fig. 1) that have an average carbon isotopic composition of $-23.8 \pm 0.1 \%$. At the same time we have obtained analyses for 18 samples of Exxon Valdez residues (fig. 1) that have an average carbon isotopic compc sition of $-29.4 \pm 0.2 \%$. Thus, two distinct populations of oil residues, identified by their carbon isotopic compositions, exist in Prince William Sound.

It is easy to account for the residues with carbon isotopic compositions of $-29.3 \pm 0.1 \%$. These residues, rollected from beaches impacted by the 1989 oil spill, undoubtedly resulted from that spill. The residues with carbon isotopic compositions of $-23.8 \pm 0.1 \%$ are not as easy to explain. The 

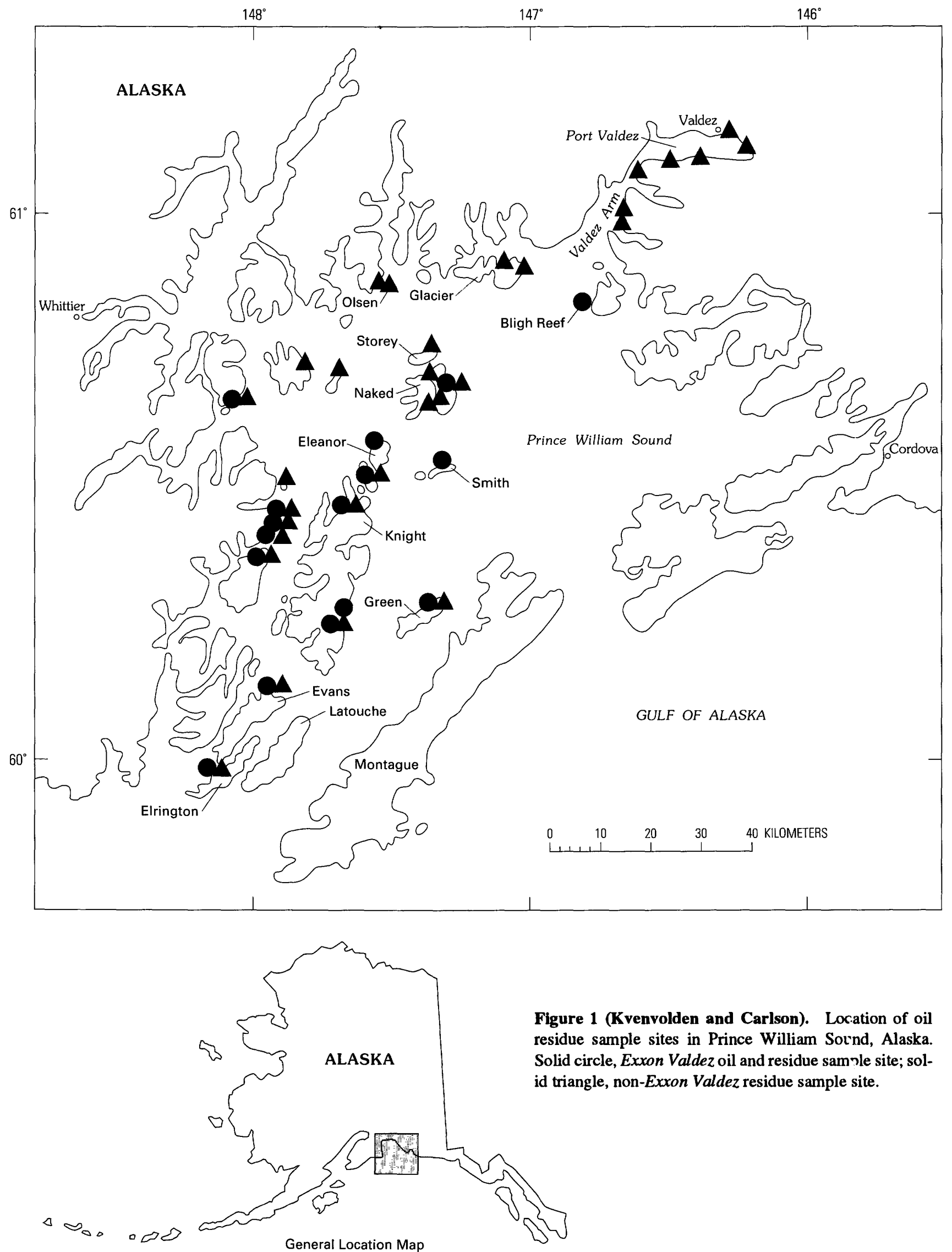
question is how residues which have geochemical signatures indicating oil produced from the Monterey Formation of California can be dispersed throughout Prince Willliam Sound. It is not unexpected to find that California oil products were used in Alaska before Alaska's internal supply of oil was available. Alaska received much of its oil and oil products by barge from southern California. Whittier, in the western part of the sound, and Valdez, at the north end, served as ports for fuel oil and asphalt storage from California for more than 50 years.

The non-Exxon Valdez residues could represent early contamination of the sound by numerous small spills of paving and roofing tar, ship discharges, and products spilled from storage facilities. However, the tight range of carbon isotopic values of the non-Exxon Valdez residues $(-23.8 \pm 0.1 \%$ o $)$ suggests that these residues not only came from products that originated in California but also came from the same batch of products; that is, these residues, at least most of them, may have resulted from a single event. We believe that the Great Alaska Earthquake, which occurred on Friday, March 27, 1964, could be that event (Kvenvolden, Carlson, and others, 1993). During this quake and subsequent tsunamis, fuel oil and asphalt storage plants in Valdez were destroyed, spilling unknown amounts of oil products into the Port Valdez fjord (fig. 1). A map (Wilson and Tørum, 1972) shows that $\approx 30$ percent of the fjord was covered with asphalt after the quake. There is no record of any asphalt cleanup, and it is likely that the asphalt progressed from the east end of the fjord through Valdez Arm and south into the sound (fig. 1). Asphalt is still present at the site of the storage facilities where the old town of Valdez was located.

Figure 1 shows that non-Exxon Valdez residue samples were found on beaches from Valdez south to the lower end of Elrington Island, whereas Exxon Valdez residues were found south of Bligh Reef where the supertanker grounded. On several beaches both Exxon Valdez and non-Exxon Valdez residues were found. Thus the beaches record two oil spills, 25 years apart, in Prince William Sound. Residues from the spill of 1989 correlate with the North Slope crude oil carried by the Exxon Valdez supertanker. The postulated spill of 1964 is less certain. Residues of California oil products are without doubt widespread on the beaches of Prince William Sound and apparently are quite refractory, but just how the residues reached the beaches is uncertain. The Great Alaska Earthquake of 1964 offers a possible trigger for a major spill of oil products that passed through the sound, as did the oil from the 1989 spill, leaving a legacy of minor residues on the beaches.

\section{Acknowledgment}

The carbon isotopic compositions, which are critical for this study, were provided by C.N. Threlkeld and A. Warden, USGS, Denver, Colorado.

\section{REFERENCES}

Galt, J.A., Lehr, W.J., and Payton, D.L., 1991, Fate and transport of the Exxon Valdez oil spill: Environmental Science and Technology, v. 25, p. 202-209.

Kvenvolden, K.A., Hostettler, F.D., Rapp, J.B., and Carlson, P.R., 1993, Hydrocarbons in oil residues on beaches of islands of Prince William Sound, Alaska: Marine Pollution B rlletin, v. 16, p. 24-29.

Kvenvolden, K.A., Carlson, P.R., Threlkeld, C.N., and Warden, A., 1993, Possible connection between two Alaskan catastrophes occurring $25 \mathrm{yr}$ apart (1964 and 1989): Geology, v. 21, p. 813-816.

Wilson, B.W., and Tørum, A., 1972, Effects of tsunamis--An engineering study, in The Great Alaska Earthquake of 1964: Washington, D.C., Oceanography and Coastal Engineering. National Research Council, National Academy of Sciences, p. 361-523.

\section{Using Geomorphology in Mapping for Oil Spill Planning}

Robert Pavia, National Oceanic and Atmosnheric Administration, Hazardous Materials Response and Assessment Division, 7600 Sand Point Way, N.E., Seattle, WA 98115-0070, and Jacqueline Michel, Research Planning, Inc., 1200 Park Street, Columbia, SC 29202

\section{Introduction}

Over the last 15 years, immeasurable effort has been expended mapping fish, wildlife, and sensitive environment components of oil spill contingency plans. Scientists in North America, Europe, and elsewhere have publisted their mapping approaches. Baker (in press) recently reviewed sensitivity mapping methods in the context of oil spill response planning.

The Hazardous Materials Response and Assessment Division of the National Oceanic and Atmospheric Administration (NOAA) is using a specific approach to sønsitive environment mapping known as the Environmenta' Sensitivity Index (NOAA, 1993). Since 1979, when the first maps were prepared days in advance of oil arriving from the IXTOC 1 well blowout in the Gulf of Mexico, Environmental Sensitivity Index (ESI) atlases have been prepred for most of the U.S. shoreline. Sensitivity mapping projects using this approach have also been conducted for coastal areas of France, Germany, Italy, Nigeria, Kuwait, Saudi Arabia, Egypt, Israel, Jordan, United Arab Emirates, Malaysia, and New Zealand.

Three general types of information are found in ESI maps: habitats ranked according to geomorphological characteristics, sensitivity to spilled oil, natural persistence of oil, and ease of cleanup; biological resources 
including oil-sensitive animals and plants, with information at the species level; and human-use resources, such as high-use amenity beaches, parks, and marine sanctuaries. The intertidal habitat ranking scheme is based on an understanding of the complete coastal environment, not just the substrate type and grain size. Key to the rankings is an understanding of the relationships between physical processes and substrate that produce specific geomorphic shoreline types and predictable patterns in oil behavior and sediment transport patterns. The habitat ranking system has been widely incorporated into spill decision-making aid including manuals, matrices, and planning documents.

\section{Creating and Updating ESI Maps}

Sensitivity mapping is a continuing and evolving activity; more than 2,200 ESI maps have been published since 1979. The Hazardous Materials Response and Assessment Division has an active program for updating existing ESI maps in areas that warrant revision because new data are available.

Because ESI maps form the basis for establishing protection priorities, it is critical that State and Federal natural resource managers are in accord with the information that ESI maps present. ESI mapping is a cooperative effort in collecting, processing, and verifying the accuracy of the final data. Cooperation comes from Federal agencies, State agencies, and private industry.

Table 1 lists the ESI project areas for 1994 and 1995, all of which have been developed as both digital and hard-copy map products. Each of these projects is a cooperative effort, receiving data, support, and funding from several sources. None of the projects would be possible as an independent activity.

\section{Electronic Publishing of ESI Data}

NOAA is undertaking a comprehensive program to provide electronic access to new ESI data and to existing data formerly available only as hard-copy maps. Through a cooperative effort with the Marine Spill Response Corporation (MSRC), NOAA is receiving digital versions of 1,400 paper ESI maps. As part of a 3-year project begun in 1994, NOAA is providing access to these data so that organizations can exploit them for response operations.

Three steps are necessary to transform ESI digital data sets into a form that has application for a broad spectrum of users.

1. Defining data dictionaries and recovering metadata for each data set. This activity provides the information necessary to ensure data quality, document data lineage, and provide a framework to document changes in the data. This work follows the national standards being defined by Federal Geographic Data Committee (1994).
Table 1 (Pavia and Michel). ESI project areas and publication date for 1994 and 1995.

\begin{tabular}{llll}
\hline Project area & Date & Project area & Date \\
\hline Cook Inlet, Alaska & 1994 & Mississippi & 1995 \\
Southeast Alaska & 1994 & Alabama & 1995 \\
Northern California & 1994 & Charleston, S. C. & 1995 \\
Central California & 1994 & Delaware Bay & 1995 \\
Southern California & 1995 & Lake Superior & 1994 \\
Northeast Texas & 1994 & Lake Michigan & 1994 \\
& & (northern shore) & \\
Central Coastal Texas & 1995 & Lake Huron & 1994 \\
\hline
\end{tabular}

2. Evaluating data quality, updating data assignments to current standards, and updating data from the MSRC data set. ESI data have been collected over 14 years. During this step, existing data are compared with potential new data sources to determine updating needs and methods. Where new digital data sources exist, such as information concerning sea bird nesting colonies, they wil be used to update older ESI data.

3. Translating the data to software-ir dependent formats for distribution. Data elements need to be combined and organized into logical units for storage, transfer, and display. This step includes publishing the dat ${ }^{\star}$ in the Spatial Data Transfer Standard defined by the Federal Geographic Data Committee (National Institute for Standards and Technology, 1992).

As these data are processed, they will be made available to users on a State-by-State basis. Work during the first year of effort concentrates on organizing and indexing the data. Key elements of this first-year effort include developing data definitions and inventorying the complete data set, including all the individual data elements. Work in the second year focuses on operational conversion, updating. and publishing data for general availability. The primary publishing mechanism will be CD-ROM, allowing low-cost distribution of large data sets. The second year's objective is to make integrated ESI data sets available for the highest priority port areas in the United States, including providing online access via the Internet for some data.

\section{REFERENCES}

Baker, Jenifer M., in press, Sensitivity mappin - for oil spill response: London, International Petroleum Industry Environmental Conservation Association.

Federal Geographic Data Committee, 1994, Cortent standards for digital spatial metadata: Washington, D.C., Foderal Geographic Data Committee, June 8, 1994, 54 p.+app»ndices.

National Institute for Standards and Technology, 1992, Federal information processing standard publication 173 (Spatial data transfer standard): U.S. Department of Cormerce.

NOAA, 1993, Guidelines for developing digital environmental sensitivity index atlases and databases: Seattl?, Wash., NOAA, Hazardous Materials Response and Assessment Division, 43 p.+appendices. 
Red Slime, Oily Films, and Black

Rocks-Sensing the Iron Bacteria That Make Neutral Streams Look Acid

Eleanora I. Robbins, ${ }^{1}$ John E. Anderson, ${ }^{2}$ Melvin H. Podwysocki, ${ }^{1}$ Harry M. Edenborn, ${ }^{3}$ Jane R. Eggleston, ${ }^{1}$ Douglas Growitz, ${ }^{4}$ Robert L. Kleinmann, ${ }^{3}$ Arnold W. Norden, ${ }^{5}$ Margaret E. Passmore, ${ }^{6}$ Byron J. Prugh, Jr., ${ }^{7}$ Mark R. Stanton, ${ }^{8}$ Palmer C. Sweet, ${ }^{9}$ Timothy M. Vandyke ${ }^{10}$ ('U.S. Geological $^{1}$ Survey, Reston, $V A ;{ }^{2}$ Army Corps of Engineers, TEC, Ft. Belvoir, VA; ${ }^{3}$ U.S. Bureau of Mines, PRC, Pittsburgh, PA; ${ }^{4}$ Office of Surface Mining, Washington, $\mathrm{DC} ;{ }^{5}$ Maryland Dept. of Natural Resources, Annapolis, MD; ${ }^{6}$ U.S. Environmental Protection Agency, Philadelphia, PA;

7 U.S. Geological Survey, Richmond, VA;

${ }^{8}$ U.S. Geological Survey, Denver, CO;

${ }^{9}$ Virginia Division of Mineral Resources, Charlottesville, VA; ${ }^{10}$ Pennsylvania Bureau of Mining and Reclamation, Knox, PA)

Acid mine drainage (AMD) is a solution of sulfuric acid, iron, and (in some instances) other heavy metals formed by the reaction of iron sulfide minerals with oxygen. AMD is one of the major problems affecting surface waters of the United States. In the East, AMD from abandoned and active coal mines severely impacts thousands of miles of streams; AMD from hard rock mining for precious and other metals similarly impacts streams in the West. The methods and information sources used to estimate AMD-impacts vary from State to State, reflecting the complex nature of the problem and a lack of national standards. A cost-effective, objective, and repeatable method is needed to provide a consistent estimate of AMD impact on streams.

The purpose of our research is to develop and refine ways of differentiating between acid and neutral streams using remote-sensing methods. To this end, we are integrating our knowledge of rock chemistry, metal availability, water flow and chemistry, bacterial precipitation, spectral reflectance properties, and remote-sensing systems to predict the general health of streams containing iron and manganese precipitates.

Streams are dynamic systems. In iron- and manganeserich provinces, evidence of iron transport is quite visual, but the red-orange precipitates in neutral streams are easily confused with the yellow-orange precipitates in acid streams. The presence of precipitates of yellow/orange/red/and brown colors is usually considered a grim signal of the failure to remove iron and manganese from the crtflow of mining operations (U.S. Bureau of Mines, 1994). However, red flocculates, oily films, and black-coated rocks are products of normal reactions and form naturally (Rohbins and Norden, in press) in healthy, near-neutral streams (pH $7 \pm 2$ units). In contrast, where streams are acid, precipitates may be so yellow that in some regions they are called "yellow-boy."

Many processes interact to combine iron an 1 manganese with oxygen; some are chemical, whereas others are biological. The colorful flocculates in streams aro biologically produced by two very different populations $\mathrm{c}^{\mathrm{f}}$ bacteria that precipitate iron and manganese. They precipitate these elements because of their metabolic processes such as detoxification, obtaining energy, and byproduct reactior ‘ that can cause iron and manganese to combine with oxyger (Ghiorse and Ehrlich, 1992). In acidic environments associated with mine runoff, iron-oxidizing bacteria within a grc $1 p$ called Thiobacillus alter pyrite to yellow-orange iron precipitates and sulfuric acid (Singer and Stumm, 1970). In contrast, another group called "iron bacteria" thrive in nerr-neutral environments, where iron- and manganese-bearing anoxic ground water discharges into streams. Bacteria surh as $\mathrm{Gal}$ lionella, Leptothrix, Siderocapsa, Siderococcus, Siderocystis, and Toxothrix thrive in near-neutral waters and fix the iron- and manganese-oxide minerals in streams (Robbins and others, 1992).

Our hypothesis is that passive spectral measurements of unique bacterial precipitates can be correlated with water quality measurements. This correlation can then form the basis for a remote water quality assessment technique for streams affected by AMD. Remote and in-place sensing techniques, which rely on differences in reflectance and absorption, have been used to prospect for spectral variations in weathering products around ore deposits (Alexander and others, 1973; Goetz and Rowan, 1981) and mining byproducts in streams (Clark ant others, 1993). Carboni and Moreau (1990) evaluated several sensors for water quality monitoring. The develonment of remote techniques that could indicate the presence of AMD in quantifiable terms could increase the efficiency of compliance monitoring by agencies such as U.S. EPA (Environmental Protection Agency). Furthermor?, such a tool could help the Office of Surface Mining to establish priorities for addressing environmental problems on abandoned mine lands.

Our research suggests that remote-sensing methods can discriminate between acid and neutral drainages tracause of absorption features of the precipitates. Ground-l ased and laboratory spectral reflectance measurements t ${ }^{\text {ken }}$ over several months have successfully separated the two different stream environments containing distinctive microlial populations (fig. 1). The acid precipitates are in gener'' brighter in color and have their reflectance maxima displaced towards shorter wavelengths. Visually, the yellow 


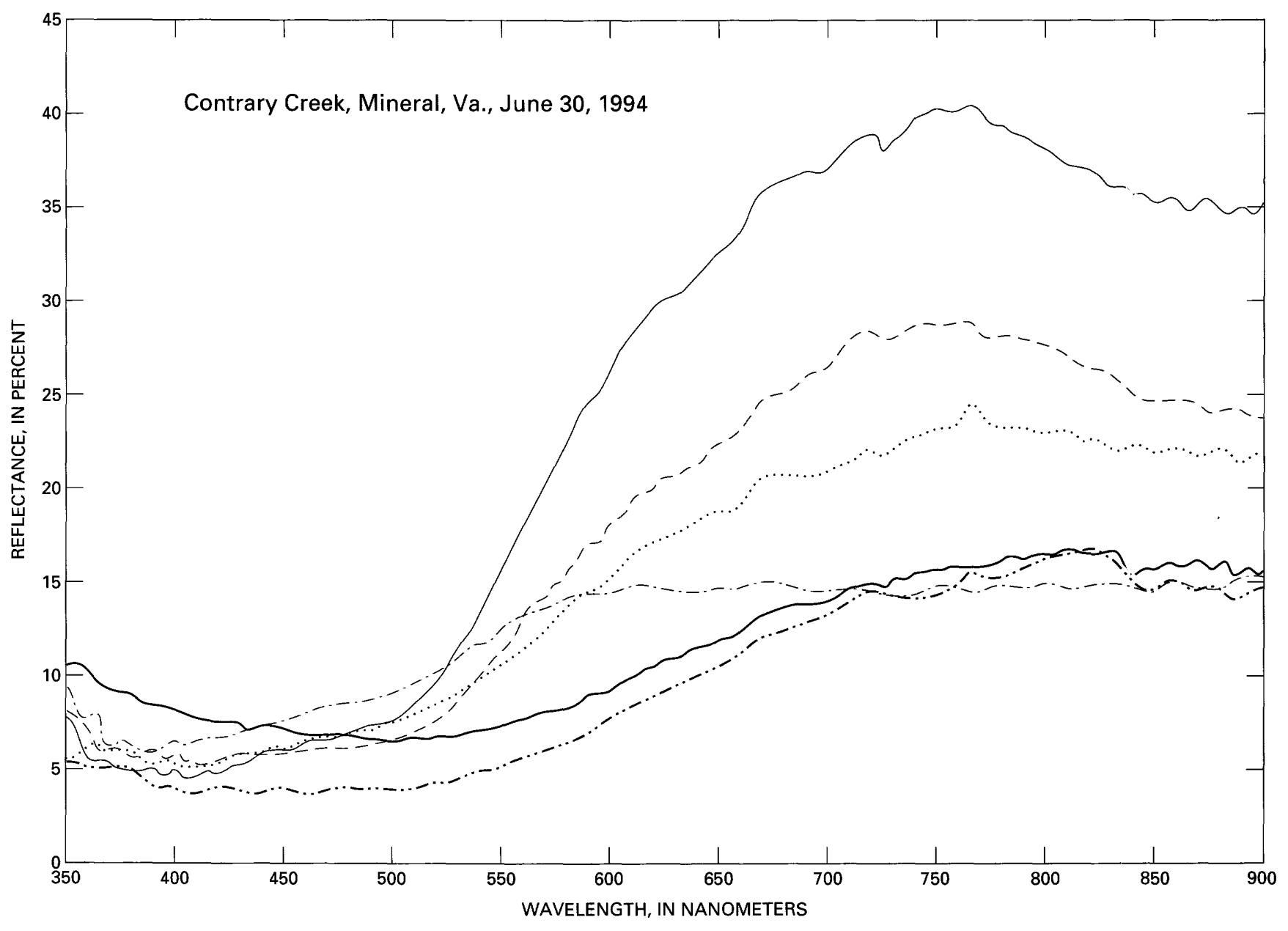

EXPLANATION

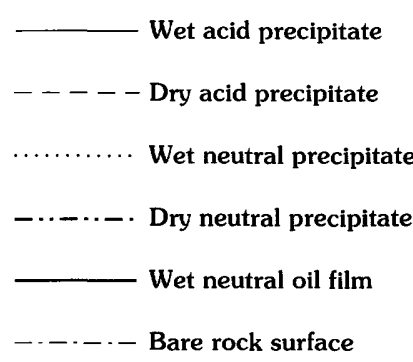

Water quality - Contrary Creek

pH 3.5

D.0. $9.1 \mathrm{ppm}$

S. Cond. $570 \mathrm{mS}$

REDOX -415 mv

Temp. $25.3^{\circ} \mathrm{C}$

Water quality - Neutral seep

pH 6.25

D.O. $2.2 \mathrm{ppm}$

S. Cond. $74 \mathrm{mS}$

REDOX -15 mv

Temp. $21.5^{\circ} \mathrm{C}$

Figure 1 (Robbins and others). Spectral measurements of microbial precipitates in acid and near-neutral water in an arid creek and neutral seep from the Contrary Creek study site in the Virginia Gold-Pyrite Belt. Average spectra for wet precipitates in acid (solid line) and near-neutral waters (dotted line) show distinct spectral reflectance peaks. Bacterial precipitates have distinct spectral prop $\times r t i e s$ in the visible and very near reflected infrared part of the spectrum which are temporally and spatially consistent. Both the acid and near-neutral bacterial precipitates have intense ferric-iron absorption features in the ultraviolet (UV) part of the spectrum, causing a diminisher reflectance in the blue and green parts of the spectrum. Both groups also have additional weaker features in the $0.8-0.9$ micrometer region. Both the UV and the $0.8-0.9 \mu \mathrm{m}$ features are due to electronic absorption bands related to the valence shell states in the ferric iron atom. However, both the amplitude of the reflectances in the two groups and the exact position of their absorption features are sufficient to distir guish and identify the two different groups of iron precipitates. (See text for additional information.) On nearby rocks, dry acid precipitater (dashed line) and neutral precipitates (long-dash-two-short-dashed line) similarly have different peak heights. Bare rock (dash-dot line) reflectance profile is shown on graph also. Minor features on the curves are related to atmospheric gases and aerosols. 
flocculates of acid creeks are much brighter than the more red hued flocculates of neutral creeks.

In the future, we will apply airborne hyperspectral imaging, as well as airborne and satellite multispectral imaging, to determine the ideal altitude and spatial and spectral resolutions that will distinguish acid from neutral drainages. We also plan to study the changes that occur in the iron precipitates as they desiccate, such as would occur as stream levels lower during the dry season, in order to determine if the precipitates have diagnostic spectral features even in their desiccated states. The ultimate application of these methods will be to focus on remotely documenting the actual extent of mine drainage contamination and perhaps even identify areas where new mining is likely to cause future problems.

\section{REFERENCES}

Alexander, S.S., Dein, J., and Gold, D.P., 1973, The use of ERTS1 MSS data for mapping strip mines and acid mine drainage in Pennsylvania, in Freden, S.C., and Mercanti, E.P., eds., Symposium of Significant Results Obtained from The Earth Resources Technology Satellite 1, Volume 1: Technical Presentations, Section A, Washington, D.C., NASA, p. 569-575.

Carboni, S., and Moreau, A., 1990, Valuation of Landsat-TM data in the identification of mine tailing zones-A case study taken from the Rouyin-Noranda area, Quebec, Canada: Proceedings of the 23rd International Symposium on Remote Sensing of the Environment, v. 11, p. 73-746.

Clark, R.N., Swayze, G.A., Boardman, J., and Kruse, F., 1993, Comparison of three methods for materials identification and mapping with imaging spectroscopy: Summaries of the 4th Annual JPL Airborne Geosciences Workshop, v. 1, AVIRIS Workshop; JPL Publication 93-26, p. 35-36.

Ghiorse, W.C., 1984, Bacterial transformations of manganese in wetland environments, in Klug, M.J., and Reddy, C.A., eds., Current perspectives in microbial ecology: American Society of Microbiology, Washington, D.C., p. 625-632.

Ghiorse, W.C., and Ehrlich, H.L., 1992, Microbial biomineralization of iron and manganese: Catena Supplement, v. 21, p. 75-99.

Goetz, A.F.H., and Rowan, L.C., 1981, Geologic remote sensing: Science, v. 211, p. 781-791.

Robbins, E.I., D' Agostino, J.P., Ostwald, J., Fanning, D.S., Carter, V., and Van Hoven, R.L., 1992, Manganese nodules and microbial oxidation of manganese in the Huntley Meadows wetland, Virginia, USA: Catena Supplement 21, p. 179-202.

Robbins, E.I., and Norden, A.W., in press, Microbial oxidation of iron and manganese in wetlands and creeks of Maryland, Virginia, Delaware, and Washington, D.C.: 11th Annual International Pittsburgh Coal Conference, Pittsburgh, Pa., Sept. 12-16, 1994, 6 p.

Singer, R.C., and Stumm, W., 1970, Acid mine drainage-The rate-determining step: Science, v. 167, p. 1121-1123.

U.S. Bureau of Mines, 1994, Proceedings of the International Land Reclamation and Mine Drainage Conference and 3rd International Conference on the Abatement of Acidic Drainage: U.S. Bureau of Mines Special Publication SP 06D-94, v. 1, 440 p.; v. 2, 433 p.; v. 3, 353 p.; v. 4, 422 p.
Radionuclides-Energy Resources and Environmental Hazards

\author{
R. Randall Schumann, Sigrid Asher-Bolinder, \\ Warren I. Finch, Linda C.S. Gundersen, \\ James K. Otton, Douglass E. Owen, \\ Charles T. Pierson, G. Michael Reimer, and \\ Robert A. Zielinski, U.S. Geological Surve"", \\ Denver, CO 80225-0046
}

Since the 1940's, the USGS has had a far-reaching, applied and basic research program dedicated to rssessing energy resources and environmental hazards from naturally occurring radioactive elements. The knowledge and experience gained by USGS scientists through some 50 years of uranium research provide detailed information on the location and extent of known and potential hazards arsociated with mined and unmined uranium concentrations $a$ ? well as quantitative data on radioactive and geochemical hazards in rock, soil, water, and air associated with uraniun and its radioactive decay products. This abstract highligl 's some recent accomplishments of this research.

Ongoing radon projects include the Geologis Radon Potential of the United States (fig. 1), compiled by USGS scientists under an interagency agreement with the U.S. Environmental Protection Agency (EPA) to answer the Congressional need for a national radon hazard assessment and provide guidance for adoption of radon-resistant building codes for new construction. This assessment integrated five factors-bedrock and surficial geology, gamma ratioactivity, soil permeability and moisture characteristics, existing indoor radon data, and house construction informetion-to give a numerical radon potential score to each of the geologic areas delineated on the map.

The identification of areas of extreme radon concentrations is also being addressed on a national scale in the High Radon Homes project, an interagency effort amon? USGS, the U.S. Department of Energy (DOE), EPA, Lawrence Berkeley Laboratory, and several State and university cooperators. In this project, the distribution of indoor raton concentrations is being quantitatively modeled using geologic and cultural parameters to locate areas of probable extreme indoor radon exposure. Regional studies in New York, Minnesota, and Washington are providing more detriled and refined data on geologic and climatic factors and processes that control radon distribution in the geologic environment. Other regional studies in the Atlantic and Gulf Coartal Plain and the glaciated upper Midwest provided baseline geologic data on the natural occurrence of radon in two broad geologic areas as well as basic research on radon behavior and transport in rocks and soils.

A quantitative radon potential map has been created for the State of Florida by a consortium of USG ${ }^{\circ}$. State, 
university, and private researchers. The map was created by merging a mathematical model of radon movement in soils with geologic, soil, and aerial radiometric data to calculate radon entry values for mapped areas across the State. The model integrates data for the radium content of the soil and underlying substrate, the radon emanating power of soil materials, the soil moisture content, seasonal water-table fluctuations, and soil permeability, density, and porosity. Maps generated using this model can portray (1) calculated values of radon entry in a standardized Florida residence; (2) actual expected indoor radon values; or (3) areas of low, moderate, and high radon potential for use in adopting radon-resistant building code standards.

County-scale studies using soil-gas radon surveys and mapping techniques, such as in Fairfax County, Va., and Montgomery, Prince Georges, and Frederick Counties, Md., illustrate the field techniques used to locate and characterize local areas of extreme radon concentrations and the use of soil-gas radon surveys to identify hidden geologic structures such as faults. Radon can be used as a natural tracer and as an indicator of geologic structures or soil chemistry. For example, in Frederick County, Md., several east-west soil-gas radon sampling traverses across the Triassic Border fault in the western portion of the county indicated a marked difference in soil-gas radon concentrations in the region of the fault trace. The abrupt change in radon concentration did not always correspond with the mapped location of the fault trace and may suggest that the actual contact zone is displaced by a few tens to a hundred meters. Information on this scale could be an important adjunct to studies dealing with the location and placement of repositories for environmentally sensitive materials, such as nuclear power plants, and radioactive or other hazardous waste disposal sites.

Mined uranium deposits, known uranium occurrences, and even yet-undiscovered deposits pose environmental concerns. Nearly all of the uranium mines occur in the Western States, particularly in sandstone formations in the Colorado Plateau region of Arizona, Utah, New Mexico, and Colorado; the Rocky Mountains and associated intermontane basins of Wyoming, Colorado, South Dakota, and Nebraska; and the coastal plain of south Texas. A few large deposits and many small ones are associated with volcanic centers in the Basin and Range province of Nevada and adjoining States. Large localized high-grade reserves of uranium occur in the Appalachians in the Northeast, and many parts of Florida, Montana, and Idaho are underlain by lowgrade uranium-bearing phosphorite, which has yielded a significant uranium byproduct in the manufacture of fertilizer. The environmental concerns consist of radioactive and chemical contamination of air, land, and surface and ground waters. Study of our digitized database of the geographic and geologic distributions of uranium deposits ard mining areas in the Western States has identified locations of most concern, especially in public lands and populated areas. The Front Range of Colorado has been chosen for an initial pilot study to delineate in detail those areas most sensitive to radionuclide hazards.

Sulfide ores and high-sulfur coals are well-known sources of acid drainage and dissolved toxic elements, but less appreciated is the potential hazard of uronium liberated from sulfide-bearing shales that are commonly associated with economic deposits of coal. Sulfide-bearing shales can produce slight acidity, sufficient to release significant amounts of uranium to throughflowing surface and ground waters. This liberated uranium can be transforted long distances, and thus potentially contaminate drinking water supplies, because it remains highly soluble in noutralized pore waters as a carbonate complex.

Uranium-bearing surface and ground waters are also commonly associated with granitic rocks containing uranium. Potentially hazardous uranium concentrations $(>20$ parts per billion) in these waters can be reduced when the water flows through wetlands. Peaty wetlard deposits can concentrate uranium by factors of 10,000 or more relative to incoming waters by adsorbing the uranium on decayed plant matter. Young $(<100,000$ years) uranium-bearing wetlands pose little radiation hazard because incoming waters supply uranium, which has relatively low radioactivity, in preference to its more radioactive decay products. However, the chemical toxicity of dissolved uranium is of concern if naturally uraniferous wetlands are drained or othe-wise disturbed and the waters interact with potable water supplies.

Produced waters in oil, gas and co'lbed methane fields commonly contain as much as 35 percent total dissolved solids. These brines, and solids precipitated from them, contain varying amounts of radium and various toxic metals. The average concentration of radium in brine solids is about 900 picocuries per gram (pCi/g). Health physicists suggest that radium concentrations in excess of 5-30 $\mathrm{pCi} / \mathrm{g}$ are of concern, derending on the exposure conditions. Elevated levels of radium in oil and gas field brine precipitates have been identified in the Gulf Coast, the eastern mid-continent, and the western mid-continent regions, but elevated radium levels are likely to occur wherever modestly to highly concentrated brines occur. EPA estimates that about 30 percert. of producing oil and gas wells in the United States may have elevated levels of radium in brines and brine solids. The USGS has initiated studies to evaluate this problem. 


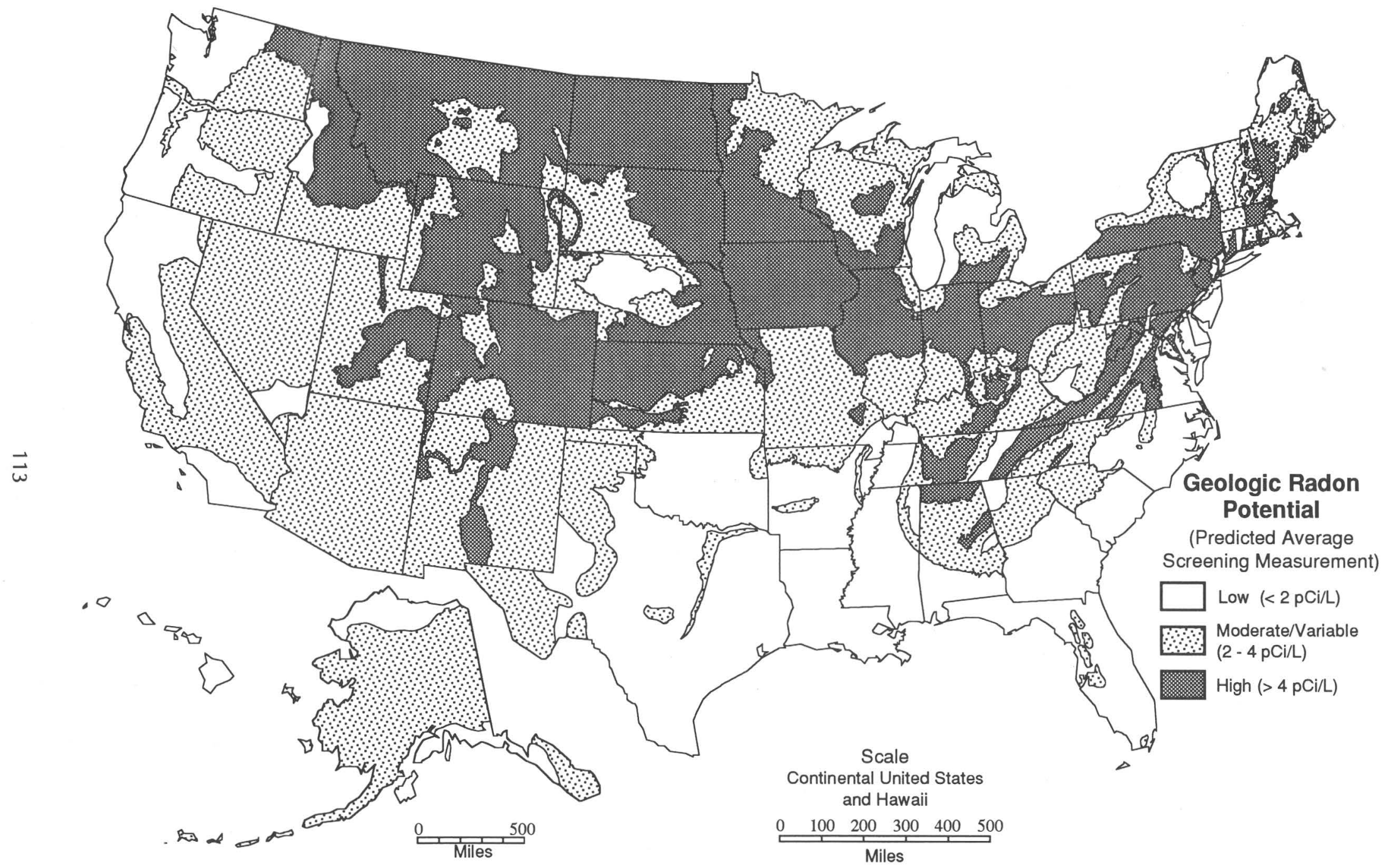

Figure 1 (Schumann and others). Generalized geologic radon potential map of the United States. 
The Effects of Oil-Field Brines on

Aquifers-Geophysical Applications in Oil Field Environmental Studies

\author{
Bruce D. Smith, U.S. Geological Survey, \\ Denver, CO 80225, and Aldo T. Mazzella, \\ U.S. Environmental Protection Agency, \\ Las Vegas, NV
}

\section{Introduction}

The U.S. Environmental Protection Agency (EPA) and the U.S. Geological Survey (USGS) have investigated the application of various geophysical methods to address ground-water contamination problems associated with oil field brine. This work was carried out in support of the EPA Underground Injection Control (UIC) program.

We present current results on the evaluation of airborne electromagnetic (EM) induction techniques to delineate subsurface brine contamination. The study was conducted at the Brookhaven oil field located just west of the city of Brookhaven, about $120 \mathrm{~km}$ south of Jackson, Mississippi. During the period from 1943 to 1986 , approximately 54 million barrels of brine were pumped to the surface from production horizons more than $1.5 \mathrm{~km}$ deep. Prior to 1978 , brine disposal followed various surface disposal methods that contaminated near-surface aquifers and streams. The current disposal practice is through deep Class II injection wells usually into the oil-bearing formations. Current practices can contaminate the near-surface aquifers through various mechanisms: failure of the integrity of the injection well, brine migration upward from nonplugged or improperly plugged idle or abandoned wells, and through vertical fractures in the confining strata overlying the injection formation.

\section{Geology and Hydrology}

Windblown sands (loess) up to $20 \mathrm{~m}$ thick cover much of the area. The Citronelle Formation (Pliocene) consists mostly of sands with basal gravel at a depth of $30-40 \mathrm{~m}$ comprising the shallowest aquifers. Deeper aquifers are sand lenses in shales of the Hattiesburg Formation (Miocene).

USGS Water Resources Division (WRD) analyses of samples from 81 water wells (Kalkhoff, 1986) have shown that the shallow ground water (less than $100 \mathrm{~m}$ deep) within the oil field has elevated dissolved solids, more than 600 $\mathrm{mg} / \mathrm{L}$ (milligrams per liter) chloride in some areas. Local background levels of chloride are less than $20 \mathrm{mg} / \mathrm{L}$. In addition, the oil field brine has a unique sodium:chloride ratio of 0.49 that allows identification of this source of contamination. A recent re-sampling and analysis of water wells in the area by WRD shows that high chloride levels still exist within the oil field (Larry Slack, written commun., 1994).

\section{Ground Electrical Geophysical Surveys}

Electrical geophysical methods can be used to map variations in subsurface resistivity. The resistivity of sediments is controlled by porosity, degree of saturation, and the resistivity (inverse conductivity) of pore fluids as well as clay content. The fluid resistivity is inversely proportional to the amount of brine or dissolved solids in ground water. Consequently, electrical methods can be used to map subsurface brine targets given a sufficient contrast in subsurface electrical properties and a sufficiently large-size target for its depth of burial.

A limited number of $D C$ resistivity soundings were carried out to determine the general nature of subsurface resistivity variations. The shales of the Hattiesburg Formation appear to have resistivities less than $100 \mathrm{ohm}-\mathrm{m}$. The basal gravel of the Citronelle Formation appears to have resistivities on the order of $200-500 \mathrm{ohm}-\mathrm{m}$. Interpretation of these soundings along a north-south profile suggests a low resistivity zone (less than $20 \mathrm{ohm}-\mathrm{m}$ ) about $500 \mathrm{~m}$ wide and extending to a depth of at least $15 \mathrm{~m}$. This and other areas of low resistivity could be due to brine and (or) clays.

A number of ground EM surveys were also conducted along roads and in cleared fields. The interpretation of the data was severely limited due to cultural noise created by buried pipelines, utilities, metal fences, power lines, and similar sources.

\section{Airborne Geophysical Surveys}

A contracted helicopter-borne geophysical survey was flown over the oil field with a flightline spacing of $1 / 8$ mile $(220 \mathrm{~m})$ and an elevation of 200 feet $(60 \mathrm{~m})$, except over populated areas. Navigation was done with a high-accuracy radar transponder with a backup photographic record of the flight path. Geophysical sensors included total field magnetic, VLF (very low frequency) passive electromagnetic (EM), and an active EM system using 900, 7,200, and 52,000 Hertz (Hz). Passive systems make use of EM signals generated by sources external to the airborne instrumentation. For the VLF measurements, $20,000 \mathrm{~Hz}$ EM signals from Navy transmission sources were used. Active EM systems use a transmitter carried with the airborne instrumentation.

USGS geophysicists flew the same area with a fixed wing STOL (short takeoff and landing) aircraft using special EM geophysical systems developed by the USGS. The flightlines duplicated the contracted helicopter survey as much as logistically possible. The processed EM data include total field magnetics and VLF.

\section{Airborne Magnetic Measurements}

In some oil fields, location of undocumented abandoned oil wells is a critical problem as they can be conduits for vertical migration of brine. Previous USGS research studies funded by the EPA have demonstrated successful 
applications of ground and airborne magnetic field measurements to locate shallow steel well casings (Frischknecht and others, 1985).

The contour map of total airborne magnetic field measurements shows many short-wave-length "bulls-eye" anomalies. These anomalies have positive amplitudes ranging from tens to hundreds of nanoteslas (nT). The larger anomalies are generally associated with steel oil storage tanks. Smaller anomalies, in some cases, are correlated with steel-cased oil wells.

\section{Passive Airborne Electromagnetic Measurements}

The helicopter VLF electromagnetic field measurements (horizontal and vertical magnetic fields) are presented by the contractor as contour maps of the total EM field. These maps mostly show anomalies associated with cultural sources (power lines and metallic structures). Consequently use of this data set to map subsurface resistivity variations is limited.

The USGS VLF airborne system measures more components of the EM field (vertical and horizontal magnetic fields, and horizontal electrical field) than the commercial system. These additional components are used to calculate apparent resistivity along each flightline. The contour map of apparent resistivity shows less influence from cultural effects than the total field VLF contour map.

\section{Active Airborne Electromagnetic Measurements}

The contractor used standard processing methods to compute apparent resistivities for each frequency along the flightlines (Smith and others, 1992). In general the highest frequency, $56,000 \mathrm{~Hz}$, has the shallowest depth of penetration (a few meters) and the lowest frequency has the greatest depth of penetration (tens of meters). Contour maps of the apparent resistivity at each frequency show minimal effects from cultural sources such as pipelines and power lines.

Additional processing of the active measurements consisted of computing an interpreted resistivity as a function of depth along each flightline (Smith and others, 1992). These calculations have been used to prepare contour maps of interpreted resistivity variations at selected depths up to $70 \mathrm{~m}$.

\section{Interpretation}

The interpreted resistivity variation at a depth of $30 \mathrm{~m}$ in the central part of the oil field is shown in figure 1 along with the location of known brine disposal pits. The location of all pits and the amount of brine disposed in them were not historically documented. Areas of high resistivities ( $>250$ $\mathrm{ohm}-\mathrm{m}$ ) probably are associated with thick loess or sands and gravel of the Citronelle Formation. Areas of low resistivities $(<25 \mathrm{ohm}-\mathrm{m})$ may be reflecting clays, shales, or saline water.
DC resistivity sounding measurements in the area of pit A (fig. 1) show a zone of interpreted shallow low resistivity. Water wells near pit A show elevated chloride levels of greater than several hundred milligrams per liter (Kalkhoff, 1986). It is very likely that the geophysical signature indicates subsurface saline waters.

The area of pit B (fig. 1) is markedly devoid of vegetation, which may indicate saline water concentration near the surface. The USGS VLF apparent resistivity map shows a distinct low in the same area, which may indicate an area of shallow saline water.

Pit C (fig. 1) is located in an area of low interpreted resistivity that extends southwest to another brine disposal pit. This area of possible subsurface brine contamination was reported to the Mississippi Oil and Gas Board, who arranged for a mechanical integrity test (MIT) of a well near the pit that had been used in the past as an injection well. The well failed the MIT test, indicating that the subsurface casing could not hold specified pressure due to casing imperfections at unknown depths. The well was properly plugged in November 1991.

Some brine disposal pits do not have either a direct or indirect association with a discrete low interpreted resistivity anomaly. One example is pit D (fig. 1). This disposal area was closed more than 30 years ago and restored by unknown methods (at that time usually by simple burial with a bulldozer). Presently this area is entirely overgrown with brush and trees that seem to be of the same character as outside the immediate area of the pit. Consequently the brine likely has been effectively dispersed in the area of pit $\mathrm{D}$. The hydraulic gradient (Kalkhoff, 1986) in the area suggests that subsurface saline waters may have migrated westward toward a creek. Any residual saline water in the immediate area of pit $D$ is not sufficiently concentrated to cause a pronounced low-resistivity anomaly.

Notice: The EPA, through its Office of Research and Development (ORD), and the USGS prepared this abstract for a poster presentation. It does not necessarily reflect the views of EPA, ORD, or the USGS. Mention of trade names or commercial products does not constitute endorsement or recommendation for use by the EPA or the USGS.

\section{REFERENCES}

Frischknecht, F.C., Grette, R., Raab, P.V., and Meredith, J., 1985, Location of abandoned wells by magnetic surveys-Acquisition and interpretation of aeromagnetic data for five test areas: U.S. Geological Survey Open-File Report 85-614A, 64 p.

Kalkhoff, S. 1986, Brine contamination of shallow ground water and streams in the Brookhaven oil field, Lincoln County, Mississippi: U.S. Geological Survey Water-Resource Investigations Report 86-4087, 57 p.

Smith, B.D., Sengpiel, K.P., Plesha, J., and Horton, R.J., 1992, Airborne electromagnetic mapping of subsurface brine, Brookhaven oil field, Mississippi, in Expanded abstracts with biographies, 1992 Technical Program: Society of Exploration Geophysicists, p. 340-343. 
BROOKHAVEN OIL FIELD

30 Meter Depth Slice

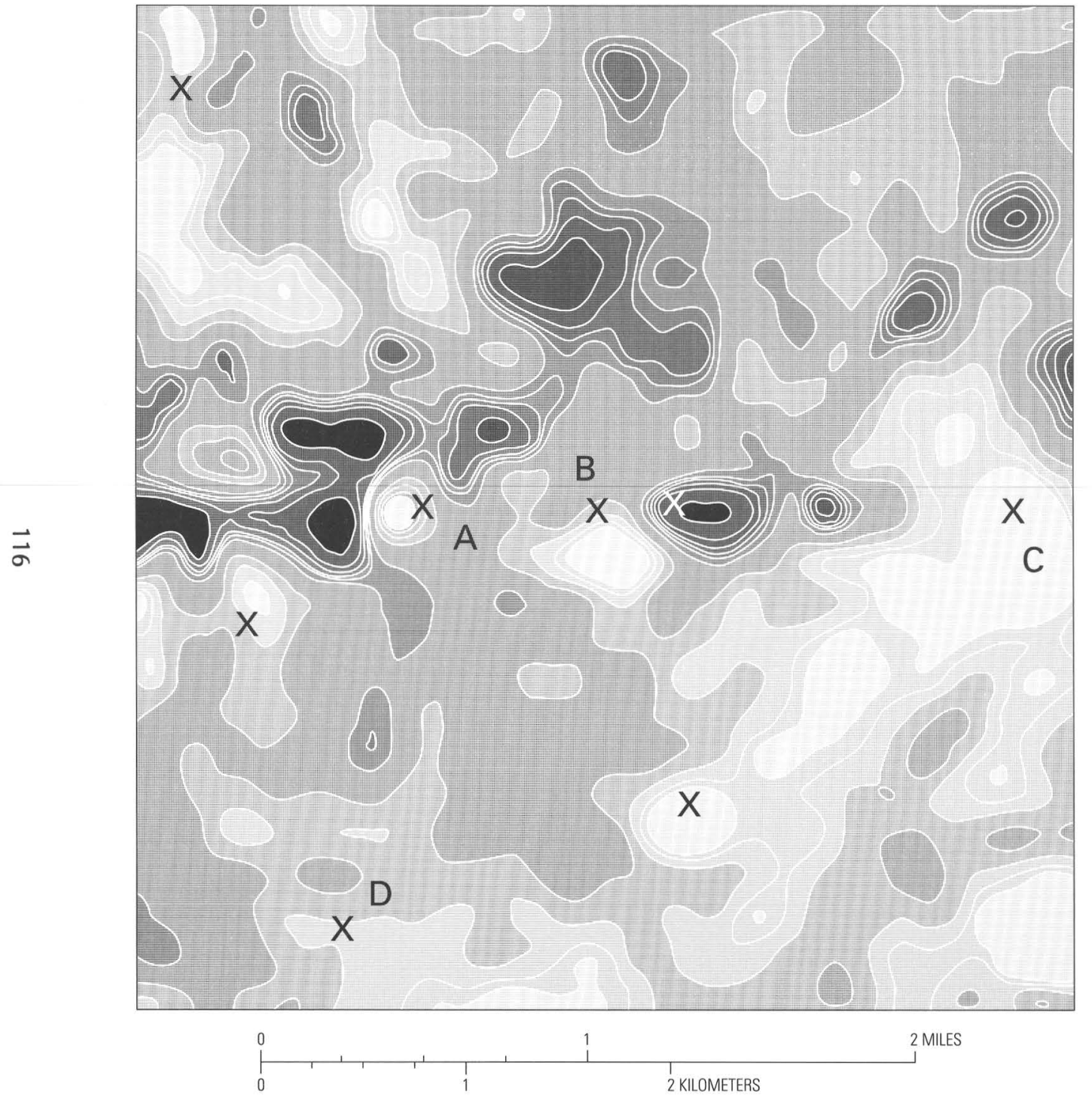

EXPLANATION

Interpreted Resistivity

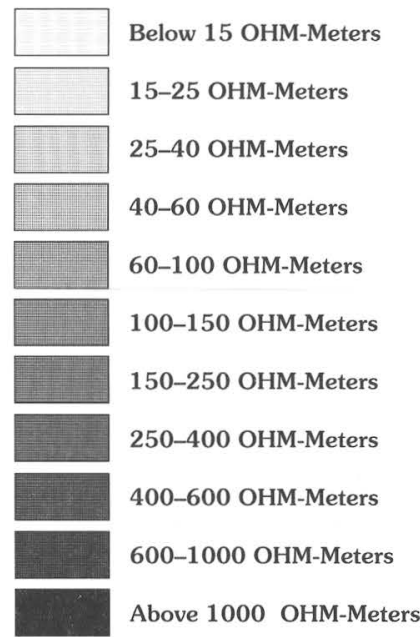

Figure 1 (Smith and Mazzella). Interpreted resistivity contour map at an estimated depth of $30 \mathrm{~m}$ for the central part of the Brookhaven oil field, Mississippi. $X$, past brine disposal pit. Letters refer to areas discussed in the text. 


\section{Environmental Impacts of Oil and Gas Pipelines}

\section{H.G. Wilshire, U.S. Geological Survey, Menlo Park, CA 94025}

Construction of oil and gas pipelines is expanding rapidly in the United States and the world. U.S. construction completions for 1992 were projected to be more than 10,500 $\mathrm{km}, 10,900 \mathrm{~km}$ for 1993 , and $6,700 \mathrm{~km}$ for 1994 . The environmental impacts of three recently built interstate pipelines (All American, from Santa Barbara County, Calif., to Upton County, Texas; Kern River, from Lincoln County, southwest Wyoming to San Bernardino County, Calif.; and Mojave, from Mohave County, Ariz. [connecting with lines from west Texas], to Kern County, Calif.) were studied in the Mojave Desert, Calif. (Wilshire, 1992). The Right-of-Way (ROW) Grants and Environmental Impact Statements (EIS) prepared by the lead Federal agency, the U.S. Bureau of Land Management (BLM), represent the anticipated area of direct construction impact as a nominal width of 21 to $23 \mathrm{~m}$.

The three pipelines were laid in graded construction zones averaging $27 \mathrm{~m}$ wide (range $21-63 \mathrm{~m}$ ) over $385 \mathrm{~km}$ of gently sloping, undissected to moderately dissected terrain, and $40 \mathrm{~m}$ wide (range $24-83 \mathrm{~m}$ ) over $85 \mathrm{~km}$ of moderately steep to steep terrain. Where corridors of two of the pipelines overlap, the combined graded width averages $44 \mathrm{~m}$ (range $30-57 \mathrm{~m}$ ) over $116 \mathrm{~km}$ of gentle terrain, and $68 \mathrm{~m}$ (range $51-118 \mathrm{~m}$ ) over $10 \mathrm{~km}$ of steep terrain. Terrain with low relief comprises medial and distal piedmont alluvial deposits, large washes, playas, and sand sheets; steep terrain comprises mountainous and deeply dissected proximal piedmont alluvial deposits.

The surveyed width and actual construction width were compared at 15 stations along $45 \mathrm{~km}$ of corridor; the results show that the width of the graded corridor exceeds the surveyed width by about 12 percent.

Current methods of pipeline installation have caused significant problems of accelerated wind and water erosion, threats to public health and safety, and long-term loss of habitat, especially in arid lands. Other impacts that may occur include visual intrusions that are enhanced because of the linear character of construction zones that cross hundreds of miles of open country, and segmentation of wildlife habitat. A moderate rainstorm of $\mathbf{4}$ hours duration in the Tehachapi Mountains eroded about 300 to 620 tha (metric tons per hectare) of soil across steep slopes of the Mojave pipeline corridor. Seven vegetation transects indicate losses of individual native perennials ranging from 11,800 to 37,900 per $\mathrm{km}$, based on the width of the construction zone in the immediate vicinity of each transect; a transect across the oldest corridor (5 years when measured) indicates a low degree of recovery.
The observed problems result from failure to implement mitigations that are stipulated in the EIS and ROW Grant, inadequacy of the environmental stipulations, and inadequate engineering oversight. The most important stipulations that were not met include (1) the requirement to trim foliage rather than blade the construction ROW (All American); (2) failure to leave roots of cleared vegetation intact (Kern River, possibly Mojave); (3) failure to remove plants of special concern (for example, Joshua trees, sensitive cacti, perennial species) and replant them on the corridor after construction (Kern River, Mojave, except for barrel cact "s); (4) failure to avoid (by route selection) disturbance to sensitive and valuable plant communities, including Joshira tree woodlands (all pipelines), desert dunes (all pipelines), and ironwood washes (All American); (5) failure to imflement visual mitigations (Kern River); and (6) failure to minimize the damage caused by grading, even in areas of level terrain (all pipelines). The best performance achieved in reducing grading is described in the habitat compensation stipr ${ }^{-}$ations as the "worst case scenario."

Inadequacies in the stipulations include (1) numerous qualifications that place unreasonable burdens on the capability of limited agency staff to oversee operations and which thereby reduce the likelihood of compliance; (2) failure to stipulate reclamation procedures for temporary storage areas; (3) inadequate stipulations for reclamation of temporary access roads; and contradictory stipulations in EIS vs Construction, Operation and Maintenance (COM) Plans, such as the blanket requirement to remove and replant after construction plants of special concern (EIS), and th ? very limited replanting (100 yuccas and 100 cacti in California) required by the Kern River Pipeline COM Plan. Since the COM Plan is reviewed only by the lead agency (BLM) after the public review period, changes in mitigations from the EIS appear to violate the National Environmental Policy Act's provision for full public disclosure of potential impacts.

A lack of rigorous engineering oversight on $a^{\prime} 1$ three pipelines resulted in substandard construction of wator bars, failure to reconstruct many drainage channels across the corridors, and failure to take special measures for the mitigation of wind erosion in sensitive areas of concern to public safety. These failures exacerbated the problems of accelerated erosion and may have created public hazards. Responsibility for implementing the mitigations belongs ultimately vith the lead Federal and State agencies.

Environmental impacts of pipeline installations could be substantially reduced by more rigorous implementation of existing mitigations. In particular, minimization of the disturbed area could be much more rigorously addressed. The environmental documents related to these pipelines provide for narrower construction ROW in numerous cases of special concern; for example, the following requirements have been stipulated for environmentally sensitive areas in EIS documents: "The pipeline project shall be limited to a 50-foot 
ROW overlapping existing ROW's***with ditch lines not more than 20 feet off of existing ditch lines. If extra construction width is necessary, it will be held to a maximum of 20 feet***." "Where the ROW follows the existing El Paso Natural Gas ROW or other existing ROW's, ${ }^{* * *}$ new disturbance will be limited to the area needed for trenching and stockpiling backfill." The damages accompanying current practices can be effectively mitigated by requiring that pipelines share construction corridors, applying the limitations in sensitive areas, as previously cited, throughout the corridors. Additional significant improvements can be effected by careful attention to restoration of all drainages, even small ones, across the corridors, proper construction of water bars, use of biodegradable netting in areas especially sensitive to wind and water erosion until the hazard is eliminated, and remediation of compaction and revegetation in temporary access roads and storage areas. A rigorous $\mathrm{F}^{\mathrm{r}}$ ogram for proactive revegetation of native plant commi nities could be developed under the aegis of various interested government agencies and industry. Such a program co"ld also aim to overcome the problems inherent in transplantation of sensitive plants, such as cacti and Joshua trees and other yucca. The damages done to especially rich vegetative communities in parts of these corridors indicate the need for critical review of presently designated routes.

\section{REFERENCE}

Wilshire, H.G., 1992, Environmental impacts of pipeline corridors in the Mojave Desert, California: U.S. Geological Survey Open-File Report 92-447, 28 p.

\section{USGS-NAVAJO COMMUNITY COLLEGE COOPERATIVE STUDY}

\section{Environmental Significance of New Mexico Coal Quality Data}

\author{
Stephanie Begay, Suzette Martin, and \\ Steven C. Semken, Navajo Community College, \\ Shiprock, Navajo Nation, N M 87420-0580
}

Pending revisions of the Federal Clean Air Act are likely to further constrain allowable releases of potentially hazardous air pollutants, principally trace elements, from coal burned for power generation or industrial heating. Selective mining or coal blending may be required for many utilities to satisfy environmental regulations. To comply with these regulations coal and utility industries will need easy access to accurate geochemical, geologic, and geographic data on coal from the U.S. Geological Survey (USGS) and State databases.

As a pilot project, we have compared coal quality data from approximately 400 samples collected and analyzed by the New Mexico Bureau of Mines and Mineral Resources to coal quality data from approximately 350 New Mexico samples from the USGS National Coal Resources Data System, to identify possible discrepancies and to suggest where further sampling and analysis may be warrante $\mathrm{d}$. We have also produced maps from the merged databases showing the lateral and stratigraphic distribution of trace elements of environmental concern within the major New Mexico coal fields. The coal quality data for coals currently mired and burned in the Colorado Plateau area, where this industry is a mainstay of the local economy, will be used to assess the potential environmental consequences of coal combustion on this fragile, semiarid ecosystem. 


\section{PAPERS REPRESENTING PANEL MEMBERS' VIEWPOINTS}

\section{Fossil Energy Technologies for the 21st Century}

\section{Thomas F. Bechtel, U.S. Department of Energy, Morgantown Energy Technology Center, 3610 Collins Ferry Road, Morgantown WV 26505}

I appreciate the opportunity to discuss my vision of the future for fossil energy. My government experience is limited, but I bring a perspective derived from 28 years as a technologist and business manager in the private sector. I have watched the commercial side of the business through the eyes of the technologist and vice versa and appreciate the difference between "market pull" and "technology push" and the tension it creates between the commercial and technology communities as they debate corporate $R \& D$ investment strategies. As we in government attempt to take on a customer focus and learn the language and culture of the private sector, the traditional competition between basic research and applied technology that clouds resource allocation in the Federal R\&D program takes on new meaning.

The National Energy Policy/Plan, which is currently in an update cycle, provides a vision for the early years of the next century. That vision provides immense challenges to the fossil energy community. But it also provides a strategic format for setting technology development goals and providing much needed focus to energy R\&D efforts. By providing technology market opportunity and timing scenarios, it allows us to plan research program phasing and investments that are more realistically aligned with the product life cycle planning of our private sector partners. It can help us avoid moving technologies toward development too rapidly and ensure that we move into expensive large development efforts with the most advanced technology feasible to meet market opportunities. Its emphasis on sustainable strategies forces environmental considerations up front in the R\&D cycle; a more balanced solution will surely evolve. The strategic perspective also forces our new ideas to compete with competitors of the future, not today's accepted product. For example, new coal-fired power generation ideas must compete with the Integrated Gasification Combined Cycle (IGCC), not today's standard pulverized coal plant.

Before going too far down the philosophical path, I'd like to briefly summarize the challenge that this future presents to the oil, gas, and coal communities.

Reducing the total consumption of petroleum products and reversing the decline curve for domestic production, that is, increasing domestic product market share in a declining market, without using taxes, tariffs, or mandates to distort market forces, is a significant marketing challenge in any case and defies all conventional marketing wisdom in the situation where the import has a significant cost advantage over the domestic product. Our challenge is to produce the "new domestic product" at a cost lower than the impoted product it is displacing. Natural gas utilization is envisicned to grow to 22-24 TCF (trillion cubic feet) annually by the year 2000 and remain at that level for an extended period. The demographic and economic forces behind that projection are already at work; the electric power industry with its growing complement of cogenerator and independent pc "wer producers already envisions at least $3 \mathrm{TCF}$ in projects already well along in development. The remainder of the demand will likely come from industrial and commercial backout of petroleum use. Small amounts of demand will accrue from residential and fleet transportation. The anrual supplier industry investment in production, transmission, distribution, and storage systems implicit in this growth projection far exceeds traditional levels for the natural gas industry. It may require the user industry, with its higher traditional investment base, to absorb both the utilization and storage investments (and possibly some of the others) via "capacity charge" approaches similar to those used with independent power producers. That is by no means an obvious solution, as many of the changes in the electric utility market have been driven by their need to reduce their investment exposure.

The role that coal is envisioned to play is critically dependent on Fossil Energy programs that are targeted to reduce capital costs and provide superior environmental performance in power generation systems. Much of this targeted market advantage comes directly from process design features, but a significant contribution comes from the dramatic improvements in energy efficiency projected for the new generation of power generation equipment-such things as gas turbines, fuel cells, MHD-all of which promise efficiencies in the 50 percent range as compared to the 30 percent range for the existing power supply system in this country. This overall increased efficiency translates irth a 33 percent reduction in the amount of fuel consumed to provide the same amount of electricity. As most environmental damage correlates with fuel use, this efficiency kicker is an automatic environmental benefit. When combined with cleaner fuels and improved pollutant removal systems. we envision dramatic gains in the environmental acceptal lity of coal-fired systems. The fossil Energy (FE) Program is addressing these challenges in both the R\&D and Clean Coal Technology (CCT) Programs.

In the Oil Program, we are working on (1) dom sstic resource characterization to reduce risk when independents acquire resources from majors, (2) field demonstrations of drilling and production stimulation technology to improve the ability of independents to employ advanced production techniques, (3) advanced production stimulation techni iues 
that will increase the ultimate yield of all fields, and (4) environmental assessment and mitigation technology that will reduce the ecological risk of oil production.

The Gas Program has broadened its perspective: it recognizes that transmission, distribution, storage, and utilization technology and regulatory improvements will play just as important a role as resource identification and production in the future role of natural gas in the U.S. energy picture. Consequently, FE activity will continue to include the resource characterization and production $R \& D$, which has already paid off in substantial reserve increases in coal bed methane, Eastern Shale, and Tight Sands and will continue to do so as we move into other basins, such as the Green River. However, it also includes advanced molten carbonate and solid oxide fuel cells for both stationary power applications, advanced gas turbines for combined cycle applications, and in-place storage systems for on-site fuel storage to alleviate daily demand peaks. These storage approaches are production in reverse. Advanced drilling and fracturing techniques are used to create new reservoirs or to expand depleted ones. They are then filled with gas from the pipeline in off-peak periods and produced during peak demand periods. By providing on-site storage, it is possible to expand gas utilization without exceeding the capacity of the natural gas delivery system.

The Coal Program has many technologies "in the pipeline" to meet the demands of the 21st century. MHD, Coal Gasification Fuel Cells, Indirectly-Fired Gas Turbines, Advanced IGCC, and Advanced PFB are all far enough along in the R\&D cycle that they were proposed for demonstration in the fifth round of CCT solicitations; all but MHD were selected and are under contract. All of these technologies are ultra-clean and highly efficient; they meet the reliable, affordable, clean energy demands of the early decades of the next century.

These technology programs have provided the U.S. energy industry and Federal energy policy leaders with the technological tools to sustain the low-cost/environmentally acceptable energy competitive edge that the U.S. economy has long enjoyed. Our productive past and the vision of a promising future should give you some level of confidence that we can sustain that advantage in the future.

\section{The Outlook for the Natural Gas Industry}

\author{
Michael I. German, Senior Vice President, \\ American Gas Association, \\ 1515 Wilson Boulevard, Arlington, VA 22209
}

\section{Introduction}

Four major factors will influence future gas markets: environmental policy; energy policy; gas industry restructuring; and technological change. In general, these factors have been and will be positives for industrial gas consumers, although Clean Air Act compliance will provide a challenge. Specifically, as regards the environment, Clean Air Act implementation, CFC phase-out, and a forus on $\mathrm{CO}_{2}$ all impact the place of natural gas in the energy mix. Implementation of previously passed energy legislation will generally help gas markets, specifically, NGV's, gas cooling, and gas in electric generation. Technology advancer will ensure gas availability at competitive prices and reduce the cost of using gas. Finally, gas industry restructuring will allow gas companies more flexibility to compete and tailor their products to meet customer needs.

\section{History}

Some of the reasons for natural gas' positive outlook are apparent. Gas consumption has jumped 25 percent from 16.7 quads (quadrillion Btu) in 1986 to 20.8 quads in 1993. 1993 gas consumption was at the highest lavel since 1979. In 1990 domestic natural gas use passed coal use for the first time since 1985-and natural gas' advantate has increased significantly since then. Gas use by industry has exceeded oil use. In 1992 new single family gas homes exceeded electric (65 percent to 29 percent) - the best percentage since 1971. Conversion of homes from electricity to natural gas reached an all-time high-nearly 100,000. Finally, natural gas pipeline and distribution construction expenditures, including storage, increased to levels not seen since the late 1960's - with 1992 and 1993 expenditures between $\$ 10$ billion and $\$ 11$ billion. These statistical indic tors all point in the same direction-up.

\section{Longer Term Gas Supply}

Whenever natural gas is discussed by customers, the question of the adequacy of gas supplies is raised. From a supply perspective, the situation for oil is often associated with natural gas-it shouldn't be. Over the last 10 years, the focus for exploration and production companies has undergone a major shift from oil to natural gas. The lower 48 States are a gas-prone geologic area. Since the early 1980's, gas producers have replaced over 93 percent of production with reserves additions. In 1993 gas well completions were up 8 percent over 1992 levels, while oil v'ell completions were down. For most of 1994, more rigs were drilling for gas than oil.

U.S. natural gas production in 1993 was about 18.4 TCF. The Nation has discovered-and has available to be produced-155 TCF of proven reserves in the lower 48 States. Proved reserves are inventory-and we have roughly 8 years. The Potential Gas Committee-the industry group that evaluates undiscovered gas resources-has estimated that an additional $753 \mathrm{TCF}$ of potential gas resources can be produced with foreseeable technology and economics. Therefore, conventional lower 48 States ga: resources total 
approximately $900 \mathrm{TCF}$. This is equivalent to 50 years supplies at the current usage level. It is important to note that the United States has had 8 to 10 years of proved reserves and 50 years of conventional resources since 1977-and will have these amounts well into the next century.

In addition to conventional gas resources, currently producing unconventional gas resources could double our gas potential. These unconventional sources include eastern Devonian shales, western tight sands, coal seam methane and enhanced gas recovery. Technology development will result in these vast supplies eventually becoming conventional: some of these resources are already being produced commercially ( $1 \mathrm{TCF} / \mathrm{yr}$ of coal seam gas is being produced today).

In addition to lower 48 States gas (both conventional and unconventional), a number of other gas supply sources will increase their contribution. These include Canadian gas (10 percent of U.S. supplies) and LNG (liquefied natural gas) (after 2000 up to 3 percent).

\section{Gas Technology and Gas Supply}

Over the last 10 years the "consensus" projections that could always be counted on as being wrong were (1) the forecast of gas reserve additions, (2) the imminent demise of the gas bubble, and (3) the coming gas price spike. In each of these instances, gas supply potential was underestimated. These incorrect forecasts were related - they failed to understand improved technologies and efficiencies occurring in the Nation's gas fields.

Technological changes influence three basic elements of gas supply: exploration, production, and new resources. These are not mutually exclusive areas-in fact some recent successes have resulted from integrating them-but characterizing new technologies in these areas can clarify their impact on gas supply and economics.

Exploration.-Significant advances have been made in geophysics, geology, and geochemistry. These advances have improved finding rates and discoveries per well drilled. After 15 years (1965-1980) of declining discoveries per well drilled (both in term of success rates and gas found per success), these ratios stabilized in the early 1980's and began to rise in the late 1980's. Exploration advances have been the product of new computer technology. Generally, a tremendous amount of geophysical/geologic data has always been available to the exploration geologist. The bottleneck has been handling and interpretation of these data. Computers are solving this problem. An example of this is three-dimensional seismology. This technology significantly helps identify drilling sites in complex geologic formationssuccesses in the Western overthrust belt and the subsalt play in the offshore Gulf of Mexico can be attributed to 3D seismology.

Gas supply models have tended to lag behind the advances already made in geologic/geophysical capabilities.
This results in less gas found per well, more dry ho'es, and thus less gas at higher costs in gas supply forecasts than can occur in the real world. This failure to incorporate new technology partially explains why gas supply potent; al was nearly always underestimated in the 1980's.

Production.-The cost of producing natural gas from a discovered field and the amount of gas recovered are dependent on production technology. Technology in this area has advanced rapidly since the mid-1970's. Successes in this area include horizontal drilling, deep-water producticn facilities, and new fracturing technology. Advances in each of these areas have lowered the cost of producing gas ir identified areas and often increased the amount of gas recoverable from identified reservoirs. For example, both hotizontal drilling and new fracturing techniques should allow more rapid and greater recovery of natural gas from tight formations. This will result in greater gas supplies at lower prices. Deep-water drilling and production technolog" also increases "forgettable" resources and lowers costs. Each of these technologies will change the shape of the rational "natural gas supply curve" favorably.

New Resources.-Certain types of natural ges have been historically excluded from the conventional reurce base. The most obvious was and is coal seam gas Until 1988 no coal seam gas was included in the conventional resource base. Today $147 \mathrm{TCF}$ of coal seam methane is included from basins evaluated in the lower 48 States and Alaska, with the potential of 600 TCF more being added over time. Other areas that fall in the "new resource" category include western tight formations, eastern Devonian shales, and enhanced gas recovery. With coal seam , these four categories could add about 100 years supply at the current consumption rate. For practical purposes, none of this potential is included in most forecasts of future gas supplies.

The two things most interesting about new gas supply technologies are (1) the diversity of advances being made, and (2) the failure of most analysts to integratie these advances into their supply models. These two pheromena are related. It is much easier to model a one-time technological "miracle," than to estimate the impact of a dozen technological advances, most of which are evolutionery and ongoing.

Although a number of the technologies previously listed apply to both oil and natural gas, their application will be increasingly gas-prone. Until the last decade, the development of the natural gas resource base (including th? application of new technology) was a stepchild of oil exploration and development activities. This has changed somewhat-it will change dramatically over the next decade. The relative size of the undiscovered resource base, as well as the economics of exploration and production, will increasingly favor natural gas. A survey of literature (such as annual reports) by major and independent oil companies confirms the view that the exploration and production indrstry is increasingly viewing gas as the fuel of the future. 


\section{Structural Changes}

An overriding economic philosophy underpins the regulatory changes at FERC (Federal Energy Regulatory Commission) and some State regulatory commissions. This ongoing philosophy involves (1) the unbundling of utility rates and services; (2) rates that reflect the market value of the level of services received; (3) accountability on the part of the purchaser for its gas purchase decisions; and (4) the development of incentives to improve operating efficiency and increase throughput. These are straightforward concepts providing gas companies the opportunity to offer a wide array of services as well as the traditional one-stop shopping. FERC's Order 636 directly addresses the first three issues. Order 636, by increasing customer choice and accountability, pushes risk downstream. LDC's (local distribution companies) and end-users (when they choose to buy their own gas and delivery capacity) will be increasingly responsible for gas reliability and price. Over time, more and smaller customers will buy their own gas and arrange for transportation and other services. The pushing of risk downstream puts additional pressure on State public service commissioners to be responsive to changing market and financial risk conditions.

The gas transportation network is market-driven today. Contractual arrangements, gas services, rates, and operational considerations are all principally determined by competitive forces. Pipeline and distribution company services are increasingly unbundled; contractual terms are increasingly innovative and flexible; rate structures are being overhauled; and operating procedures are undergoing changes in order to respond to market requirements.

\section{Gas Demand}

The significant gas demand growth over the past 7 years has occurred in two areas: (1) the industrial sector, and (2) the residential and commercial sectors. Industrial gas use jumped from 6.7 quads in 1986 to 9.2 quads in 1993. Residential and commercial demand rose from 6.8 quads in 1986 to 8.1 quads in 1993. In contrast, electric utility gas use remained flat. This electric utility performance should be contrasted with a 1-quad increase in cogeneration gas use (a use of gas primarily to generate electricity that is included in the industrial sector).

Residential demand growth occurred despite the continuing 1 percent per year efficiency gains (conservation) in this service sector.

Given the high market share for natural gas (approximately 60 percent in new residential and commercial construction), it is projected that one-third of the growth in gas demand between 1993 and 2000 will come from these sectors. In fact, the one million residential customers added per year adds $100 \mathrm{BCF}$ (billion cubic feet)/year of gas demand.
The industrial sector will supply another one-third of the gas demand growth between 1993 and $2 C^{2} 0$. The use of gas in cogeneration facilities will continue, but not at the robust growth rates of the late 1980's and early 1990's. The slowdown in growth will be the product of slow electricity demand growth.

Finally, clean air regulations will supply' the remaining one-third-with conversion of existing electric and industrial generation plants to gas for clean air purposes dominating this market in the near term and natural gas vehicles increasing in importance throughout the perixd.

\section{The Winter of $1993 / 94$}

The gas industry hoped to test itself in the post- 636 era with a normal winter. Instead it faced an ext-zordinary January (1994) in many regions of the country.

An estimated 2,543 BCF of natural gas was consumed in January 1994, which exceeds by 5 percent the previous record set in January 1979.

Questions about the Nation's natural gas network under FERC Order 636 were at least initially arswered by the strong performance of pipelines and local distribution companies during the weather-related crisis.

-Most major pipeline systems reporterl no interruptions of firm service, and, in fact, when all th? data are available, will likely report all-time peaks on several of those systems.

-Many interruptible customers were interrupted, just as the system is supposed to work. However, by the end of that week in January, many of the companies that had earlier restricted interruptible transportation and $s^{+}$rage services had restored these services to applicable customers.

-Isolated instances of service disruptions were generally traced to the failure of metering or regulating equipment, which when discovered was repaired in a short period of time.

-Service was disrupted briefly on one pipeline system because compressors powered by electricity were subjected to rolling power outages. As a result, the abil ty to move gas through the system was reduced for a period of 15 hours. Excellent communication between the pipeline and affected LDC's helped to alleviate difficulties assoriated with the temporary disruption.

-At least one pipeline system was tem orarily denied approximately $300 \mathrm{MMCFD}$ (million cubic feet per day) of supply due to a failure at a processing plant. Fifty percent of capacity was restored within 24 hours with the remainder restored with 72 hours.

When all the data are in, many LDC's in the Midwest, Mid-Atlantic, and New England regions will report a singleday record throughput sometime during the period January 17-21, 1994. LDC's reported that gas supply was not an issue. Instead, LDC design capacity was severely tested in many areas. However, instances of coope-ation between 
distribution companies to ensure reliable service to customers were the rule rather than the exception, and in all but a few isolated situations firm customers were served.

Verdict: Gas system was much more reliable than December '89 (last major test). Systems have been put in place to improve communication and cooperation. New pipelines and storage have been built. Existing system is improved. All this has made natural gas a very reliable fuel.

\section{Economics}

The wellhead price of natural gas measured in inflationfree 1994 dollars is projected to increase gradually from $\$ 1.83$ per MMBtu (\$1.88 per MCF) in 1992 to $\$ 3.06$ per MMBtu ( $\$ 3.15$ per MCF) in 2010. Compared to an anticipated crude oil price (composite average refinery acquisition) of $\$ 4.31$ per MMBtu ( $\$ 25$ per barrel) in 2010, measured in inflation-free 1994 dollars, the average in-the-field price of natural gas is projected to be 71 percent of average refinery acquisition price of crude oil, on a dollars-per-MMBtu basis.

Natural gas is projected to remain competitive, on a dollars-per-MMBtu basis, in the commercial and industrial sectors. The average price of distillate oil in 2010 , for the United States as a whole, is projected to be 20 percent higher than that of natural gas to commercial users, and 68 percent higher than that of natural gas to industrial users. The U.S. average price of electricity to commercial users is projected to 3.9 times that of natural gas, and 3.5 times that of natural gas to industrial users in 2010.

Natural gas is projected to remain competitive with residual fuel oil and coal to electric utilities. For the United States as a whole, on a dollars-per-MMBtu basis, residual fuel oil is projected to cost electric utilities 8 percent more than natural gas in 2010. Coal is projected to cost electric utilities 47 percent less than natural gas, on a dollars-perMMBtu basis, on average in 2010, but suffers from higher handling and operating costs.

\section{Conclusion}

The technology of finding and producing gas has changed. Simultaneously, the basic legal and regulatory structure under which the gas industry operates has changed. These technological and structural changes, in conjunction with the fundamental economic and environmental advantages of gas energy, will result in gas becoming the cornerstone of future U.S. energy consumption. The structural changes when completed will eventually facilitate the development of gas supplies, help in the promotion of new gas markets, and facilitate greater efficiency.

Historically, a single energy source rises to prominence and achieves a preeminent market share of total energy consumption over an extended period. In the United States and worldwide this has already occurred for wood, coal, and oil; and the beginnings of the natural gas era date from the 1950 's. Worldwide, the trend towards a gas era has moved forward steadily, with gas use in major industrial nations outside the United States tripling between 1970 and 1086. In the United States natural gas use increased at a spectrcular rate between 1950 and 1972, with natural gas satisfyiro onethird of energy demand in 1972 . This growth was inflated by very low wellhead price controls that resulted in market share growth at a faster rate than would have occurrec otherwise. The 21 percent decline in natural gas consumption from 1970 to 1986 was the inevitable result: The U.S. gas industry went through a period of rapid growth-orowth over-stimulated by price controls-and a period of contraction caused by the same controls. With wellhead controls gone, the steady movement towards a gas era in the United States should resume, mirroring market share trends occurring elsewhere in the industrialized world.

\section{REFERENCES}

American Gas Association, 1994a, Fact sheet on natural gas industry actions January 1994, American Gas Associaticn Issue Brief 1994-2, February 4, 1994.

1994b, The gas energy demand and supply outlook 1993-2010: American Gas Association, January 1994.

DOE/EIA, 1994, Monthly energy review, June 1994.

Potential Gas Agency, 1993, Potential supply of natural ges in the United States (December 31, 1992): Colorado School of Mines, Potential Gas Agency, May 1993.

\section{Application of Geosciences to Decision- Making-It's an Idea Worth Trying and Long Overdue}

\author{
Richard L. Lawson, President, \\ National Coal Association, 1130 17th St. N.W., \\ Washington, D.C. 20036-4677
}

America's 265-billion ton reserve of recoverable coal is 95 percent of our fossil-fuel reserve. It must be used if concerns about the social, economic, and natural environments are to be balanced.

Only science and technology can achieve this balance; but they can achieve it only if scientists, such as those here, determine to address the way politics uses and sometimes abuses your profession.

And so I'd like to speak to the overall conference theme-the Application of Geosciences to De-isionMaking - before discussing coal and related question

Application of science to Federal decision-making is a good idea. On recent major questions it is one that has not been "tried and found wanting"; rather it has not been wanted and gone untried. 
Think of the recent Clean Air Act. USGS and other Federal agencies participated in the half-billion dollar National Acid Precipitation Assessment Program, called NAPAP, through the 1980's. Nothing like it had ever been done before on an environmental question. Science was mobilized to find answers: solid work was done toward solid decisions.

All the while the professional environmental lobby published cut-and-paste-together studies and called it science; they featured the scare and predictions of an end to life as we know it. Some studies became the basis of news opportunities for allies in Congress. Some seemed aimed at discrediting NAPAP interim findings. Pressure grew.

Then NAPAP reported: there is no acid rain crisis and immediate action is not necessary. But NAPAP reported too late. Perceptions had outrun the science and politics responded. A cost estimated at $\$ 30$ billion a year was imposed on Americans despite the science.

Two views of science are at work. Let's examine them by pairing recent remarks on climate change with to-thepoint observations from classic thinkers.

First, climatologist Stephen Schneider, when associated with the National Center for Atmospheric Research: "****we need to $* * *$ capture the public's imagination $* * *$ offer up scary scenarios, make***dramatic statements ${ }^{* * *}$ make little mention of any doubts. ${ }^{* * *}$ Each of has to decide***the right balance***between being right and being effective ${ }^{* * *}$."

And now biologist T.H. Huxley: "The great tragedy of science-the slaying of a beautiful hypothesis by an ugly fact."

Next, Vice President Gore, on climate change, from Earth in the Balance: "If we are to succeed, we must resist being overwhelmed by the flood of information***."

And, finally, the economist Adam Smith in The Wealth of Nations: "Science is the great antidote to the poison of enthusiasm and superstition."

NAPAP also produced the term "scientific McCarthyism." It was coined by a participant scientist who said on 60 Minutes that the "problem is so small it's hard to see," and for his remark was publicly scolded by an administration official as having limited credibility even in a limited area.

"Scientific McCarthyism" seeks to discredit the scientist rather than answer the ugly facts the scientist raises: like the original political article, it wants to intimidate rather than elucidate.

Something similar is happening in debate of the climate-change postulation. On a Nightline presentation on $\mathrm{ABC}$ television last February 24th, Ted Koppel's summation was as follows: "***the issues have to be debated and settled on scientific grounds, not politics***the measure of good science is neither the politics of the scientist nor the people with whom the scientist works. It is the immerson of hypothesis into the acid of truth. works."

"That's the hard way to do it but it is the only way that
Science is not my profession, and I shall not presume to tell scientists what to do about the politicization of science. My former profession was national security and my present one concerns energy and economic security; all three are intertwined.

And I do know the following:

-That we have two kinds of science vying in policythe cut-and-paste kind that ignores "ugly" facts to achieve scares and political objectives; and the kind that seeks understanding;

-That science diligently mobilized and I mestly applied can identify and quantify problems-incluc'ng the climate postulation-and then develop the techno'ngy to deliver solutions;

-That if those who honor the traditions of science stand silent, the cut-and-paste scares will prevail every time;

-And that Mr. Koppel is right—seeking the truth is the hard way, but the only way that works.

The postulation of climate change is not politics as usual. Every domestic and international activity associated with it is aimed at taking away energy from society's use.

Too little energy at too high a cost car be a matter of war and peace; energy makes the difference between subsistence and a strong standard of living, between widespread social unrest and a country confident the fu'ire can always be better than the present.

Within this, America's 265 billion tons of recoverable coal equal the energy in all the world's prcved reserves of oil. Today coal provides 33 percent of dcmestically produced fossil energy, the largest share; and 57 percent of the Nation's electric power; and it is 95 percent $c$ f all the domestic fossil energy we have for the future.

Tomorrow coal will have to provide more if computers are to function reliably and traffic to run smoothly on the information highway. Advanced technology exists to do this in ways that resolve concerns about the environment and deliver economic strength.

But it will not happen if scares, perceptions, and politics are again allowed to outrun the science-if the "ugly" facts and findings, that even now call the climate postulation into question, are again ignored.

The application of science to decision-making is a good idea. It's one well worth trying and long ovardue.

\section{Geoscientists, Fossil Fuels, and Climate Change-A Defector's View}

\section{Dr. Jeremy Leggett, GREENPEACE, Canonbury Villas, London N1 2PN, U.K.}

I left my career as a university geoscien tist and consultant to the oil industry in the late 1980's in large part because of my growing fears about human-enhancement of the 
greenhouse effect as a result of fossil-fuel dependency. But since then, many highly placed individuals in the oil and coal businesses have assured me that my concerns are groundless. An oil company CEO has told me that I have fallen victim to "terrorising theories and accusations" (and more, that I am now guilty of perpetuating them). A Chairman of the World Coal Institute has told me that he can't see the relevance of the global warming debate to the "real world." After 5 years as an environmentalist, I can recount many other such examples of senior oil and coal industry figures dismissing the prospect of an enhanced greenhouse effect, and consequent climate change, as a non-problem.

Employees and servicers of the coal and hydrocarbon businesses, such as geoscientists, can clearly be forgiven for concluding that they need not bother themselves with the debate. The message from the top seems to be that business as usual can be the order of the day, perhaps with a few routine concessions to energy efficiency and non-greenhouse emissions. Sit tight, the message reads, and take comfort in the case of the scientific sceptics, and their regular drip of "Global Warming Disputed" stories.

Yet a look at the real world, I submit, shows there is real and growing cause for concern. For instance, it has not escaped the attention of one industry, far bigger than the coal and oil businesses, that if global warming does come to pass as so many climate scientists now expect, the years to come might involve economic ruin. The $\$ 1.4$ trillion insurance industry is waking up fast to the threat inherent in greenhouse-gas emissions. It is easy to see why. Between 1966 and 1986, no climate-related natural catastrophe, anywhere in the world, clocked up more than a billion US dollars. Between 1987 and today, no less than 15 have.

Whether a first faint signal of human-enhanced greenhouse warming is emerging in statistics like these is a matter of debate. But the world's biggest reinsurance company, Munich Re, is among the growing body of institutions which needs no further persuasion that a signal is appearing, and more importantly, that there is much worse to come. Munich Re has made the first public industry demand for action, calling on governments, businesses, and insurers alike to "take immediate action" to address the "dramatic development of natural catastrophes." "The threatened climatic changes demand urgent and drastic measures," the company has said.

In Europe, North America, and Japan, senior figures in the industry now talk of real fears for the very future of the insurance business. As the President of the Reinsurance Association of America has put it, "The insurance business is first in line to be affected by climate change ${ }^{* * *}$ it could bankrupt the industry." Without a healthy insurance industry, it is far from clear how one runs a healthy economy. At the top of the list of knock-on [domino] effects, the employment and pensions implications do not bear thinking about.

Conventional wisdom in the citadels of the fossil-fuel businesses has it that there are too many uncertainties involved in global warming to warrant action. Uncertainties there certainly are, but global warming is all about threat assessment in the face of uncertainty. And as ore looks around the world in 1995, how lucky can one feel that the stakes are not huge, and the odds are not weighted? 1990 was the hottest year since records began 140 years ago. 1991 was the third hottest, despite the significant cooling effe $t$ of the Mount Pinatubo eruption. The eight hottest years have all now been since 1980 . Incidences of coral bleaching, and mass mortality, are proliferating in reefs-frequently in waters of unusual warmth - in the Caribbean Sea and Pacific and Indian Oceans. Suspiciously intense drough ts have struck southern Africa, northern Brazil, California, s)utheast England, and other places. Huge inundations have caused ruinous flooding in the United States, Pakistan, $\mathrm{Ch}^{\text {ina, and }}$ elsewhere. Peculiar insect infestations have been reprted in a number of countries.

No one of these things could be taken as proof that the first signs of global warming are emerging. But all of them? Don't listen to me, listen to the growing number of $s$ ?ientists who are professing that the signal is already clea-most recently spokespersons from the German Buntestag's Enquette Commission, the Japanese Maritime Safety Agency, and the Russian Hydrometeorological Centre.

And what of the future? Where science is concerned, there seems to be a constant drip of bad news. Amrng the particularly depressing discoveries recently, in February 1993 we learned that the demonstrably warming Alaskan tundra has transformed from a carbon dioxide $\sin ^{2}$. into a source. Biogeochemical feedbacks such as this are mostly omitted from climate models, suggesting that the dreadful rates of warming the Intergovernmental Panel on Climate Change forecasts may in fact be underestimates. In August 1993, we learned that ice core work in Greenland suggests that when the world was last $1^{\circ}-2^{\circ}$ warmer on avera $\mathrm{Te}$, catastrophic shifts in climate took place within a matter of years. Such changes, oceanographers tell us, are most likel" driven by ocean currents turning on and off. And in Februay 1994, we learned that the Scott Polar Institute has documented a dramatic slowdown of thermohaline circulation in the Greenland Sea over the last decade.

Many people in the oil industry do in fact see the writing on the wall in discoveries like this. The averare chief executive would be amazed if he knew how many $0^{: 1}$ industry middle managers have conceded the case to me, told me how they fear for their children the way I do for mine, told me they would be quite happy to see the BP Oils and Shell Oils of today become the Total Energy companies of tomorrow, making their money in multi-million dollar markets in solar technology and energy services.

And yet, at the intergovernmental climate negctiations, I have worked opposite high-powered lobbyists from multimillion-dollar lobby groups funded by the Board" of oil, coal, and automobile companies. They are there tc try and stop governments agreeing to limit greenhouse-gas emissions, and one of their tools is the attempted discrediting of 
the science underlying the climate models run by NASA, NOAA, NCAR, and other climatic research centres around the world. I can tell tales from the front lines of this particular carbon war which would make the honest geoscientist cringe with shame at how corporate interests can so pervert a robust broad scientific consensus.

One no longer has to be an environmentalist to believe that global warming threatens economic ruin, maybe even the end of civilization as we know it. The role of fossil fuels is central in generating global warming. The role of geoscientists is central in propping up the fossil-fuel status quo. Who, in the real world, wants that status quo on their consciences unchallenged while solar power, the rest of the renewables, and demand-side management are all so severely underemployed?

\section{Ten Reasons Why Natural Gas Prices Will Not Rise}

\author{
Dale M. Nesbitt, Senior Vice President, \\ Decision Focus, Inc., 650 Castro St. Suite 300, \\ Mountain View, CA 94041-2055
}

Some industry observers, buoyed by the destructive hurricane Andrew and the concomitant runup in spot gas prices, are optimistic and have proclaimed more bullish natural gas prices. Enron CEO Kenneth Lay stated in the New York Times (Sunday, September 20, 1992) that "We are getting back very close to a balance of supply and demand in natural gas," implying that gas prices could well increase. Is the gas bubble over? Will gas prices inexorably increase? Is gas in reality the depletable resource people believed during the crisis years of the 1970's?

Recent increases in natural gas prices are temporary, and long-term price trends for natural gas are flat, at best. Here are 10 reasons that provide ample evidence to believe that the short-term phenomenon will not persist.

1. The Wall Street Journal, September 23, 1992 shows that natural gas futures prices retreat to the same low levels in September 1993 where prices have languished for several years. Any bet on prices other than these future prices is tantamount to gambling against the market. If gas markets are efficient, as they will increasingly be as FERC Order 636 and 636A foster price transparency and competition, then futures prices are an important indicator. Empirical observations of the market do not justify assertions of nominal-dollar gas price escalation, much less real (inflation-adjusted) escalation. In fact, they suggest erosion from today's spot levels in real terms. Betting against a market would require accurate insider information or blind luck. Why bet against a price we can lock in today?

2. Spot prices have increased significantly since the end of August. However, it appears from the futures price that the destruction from hurricane Andrew has simply accelerated the normal winter pattern as pec ole seek to buttress commitments and inventories earlier than they might otherwise have. The near-term runup in gas price will surely abate, just as the NYMEX futures market pries suggest.

3. There is too much natural gas in the ground to sustain today's price. The National Petroleum Council (NPC) and the Energy Information Administration (EIA) have independently estimated the existence of almos $2,000 \mathrm{TCF}$ of natural gas potential in the United States and Canada. (This amounts to 100 years consumption at present rates.) Furthermore, DFI's World Gas Trade study shows quite clearly that LNG (liquefied natural gas) is virtually limitless if domestic prices on the North American continent rise to approximately $\$ 4.00$ per MMBtu. Canada reports approximately 100 TCF of "established" natural gas resources, and the United States has some 160 TCF. (Both estimates are generally perceived to be understated.) Establish :d-field reserve growth continues to surprise many observers. Advanced seismic- and horizontal-drilling technologies have decreased finding cost and offer the potential in many areas of the North American continent to substantially expand reserves. The pipeline system is equipped to deliver in excess of 25 TCF per year, and there are still significant new pipeline projects in late stages of development. It is r ard to conceive of anything but a world of surfeit supply with concomitant low prices.

4. Parties are interested in contin"ed free trade between the United States and Canada. The I Tational Energy Board (NEB) of Canada has stated its willin ?ness to "let the market decide" regarding pipeline export capacity. Peter Miles of the NEB said in a National Petroleum Council meeting in Denver last year that the regulatory and export environment in Canada has become more $b$ nign and more economically driven. This is extremely plausible given the realization that an increasing portion of the Canadian resource base has come under the control of multinational oil companies (such as Esso, Shell, Amoco, C evron, Mobil), who assuredly do not wish to operate with higher inventories in Canada than elsewhere. The desire to shrink inventory presages substantially increased export of Crnadian gas with concomitant downward pressure on United States gas prices. To wit, more Canadian gas in the United Sta ${ }^{+}$s means lower prices in the United States.

5. There is no historical precedent for sustained, real commodity price escalation at the bullish rates suggested, for example, in either the GRI Baseline or Enron Outlook. It is impossible to find a commodity whose historically observed, real (inflation-adjusted) prices escalated over a long period of time as rapidly as the Outlook or the Baseline suggests. While there will assuredly be short-term sp: res and valleys in spot price, there will just as assuredly be intensive activities to substitute for dwindling conventional supplies of gas as prices rise. The very fact that rising price has been observed to bring myriad entrants to the market-research 
and development organizations, producers, alternative sources of supply, new supply regions, demand suppression, and so forth. Each of these entrants, individually and collectively, places downward pressure on gas price and upward pressure on gas supply. DFI's North American Natural Gas (NARG) program has repeatedly shown natural gas price increase to be modest at best over the next 10 or more years.

6. Gas and oil prices in North America are at present quite decoupled. Gas-on-gas competition is clearing markets at prices substantially below the Btu equivalent price of oil. Escalation in oil price (if it occurs) will be largely irrelevant to natural gas price. Softening in oil price might, if sufficiently severe, drag down gas price. In fact, there is a strong case to be made that oil prices will fall within the next 5 to 10 years.

7. Rates of return in financial markets (interest rates) have been dropping (in real terms) from the unprecedented highs of the 1980's to levels more consistent with long run historical average. It is not rational for the market to allow gas inventories to appreciate in value faster than interest rates. Producers will face tremendous incentives to liquidate gas resources if interest rates rise, turning their gas into money and enjoying the benefits of escalation of that money. As they do so, near-term prices will fall and rates of subsequent price escalation will increase. Conversely, if interest rates drop, producers will have incentives to hold gas inventories, thereby holding their wealth in gas rather than in cash (which is worthless if it does not escalate in value). As they hold gas inventories, near-term prices firm and rates of subsequent price escalation slow. There is an intimate coupling between the price of an elemental commodity such as natural gas and the return in financial markets, which represents the aggregate of all other industries combined. Natural gas cannot earn above-market or below-market returns for any appreciable period of time.

8. Drilling productivity has increased tremendously, and the productivity increases seen to date will not disappear. One simply does not need as many rigs to prove oil and gas reserves, just as one does not need as many fabrication facilities to produce semiconductor chips. Like semiconductors, productivity has increased at unprecedented levels in the hydrocarbon exploration industry. As productivity gains permeate heretofore under-explored areas inside and outside North America, low-cost reserves are bound to soar.

9. Industry practice has accommodated low prices. Reserves-to-production ratios have fallen. Producers and customers have realized that they do not need to warranty contracts with reserves. The market itself takes care of all necessary warranties. Gas producers are behaving more like "just-in-time" (JIT) manufacturers in other industries. Producers and customers alike can now rely on a plethora of emerging market mechanisms to elicit necessary supply (for example, San Juan royalty trust, NYMEX, third party trading). Price signals will be unequivocal in communicating to producers any need for additional supply.

10. Oil-directed drilling is bound to create additional gas reserves. Oil-directed drilling, catalyzed by today's rather attractive oil price, will add gas reserves in two ways: (i) associated gas in successful oil wells and (ii) dry gas found "by accident" in the quest for oil. Gas reserves will grow inside as well as outside North America, placing additional downward pressure on price.

In such an environment, how can gas prices es alate?

The message would seem to be clear. Purchasers of gas will strive to "sell short," avoiding locking in price for the long term. Despite efforts to "sell long," attempting to secure indexed prices at or above today's price, gas providers are unlikely to succeed. For example, fixed-price contracts at high levels (for example, $\$ 3.00 / \mathrm{MCF}$ indexed to inflation) are unlikely to be consummated. In the present and foreseeable market, purchasers simply need not consider such contracts.

\section{Global Geologic and Economic Aspects of Oil and Gas Resources}

\author{
Dr. Nahum Schneidermann, \\ Chevron Overseas Petroleum, \\ Exploration Evaluation Dept., \\ 6001 Bollinger Canyon Road, A/3080, \\ San Ramon, CA 94583
}

Oil resources of the world are distributed une venly in the Earth's crust. Almost 50 percent of the world's proven oil reserves (as published in the trade journals) are as sociated with four countries-Saudi Arabia, Iraq, Kuwait, and Iran. Of the 69 countries containing any appreciable oil reserves, only 34 have reserves larger than 1 billion barrels. The top 12 countries account for 90 percent of the world's proven reserves. The United States ranks tenth in proven oil reserves, with about 23.7 billion barrels (Oil and Gas Journal). At present rates of production ( 2.5 billion barrels a year for 1993) and without adding new reserves, the Unit?d States has a Reserve to Production Ratio (R:P) of about 9-10 years only. For comparison, Saudi Arabia has a R:P of about 90 years, Iran of 70 years, and Kuwait 138 years.

The present global oil production rates are not directly related to the reserve distribution. Overall, the Commonwealth of Independent States (CIS) has the highest daily oil production, followed by Saudi Arabia and the United States. However, this large production is delivered from about 145,000 producing wells in the CIS, more than 600,000 in the United States, and only about 1,400 in Saudi Arabia. The remaining reserves in the CIS and United States will be 
found in technically difficult and risky areas, in areas of environmental sensitivities or high operational costs. Our future dependence on imported oil increases every time another area of our country becomes closed to petroleum exploration.

Another measure of oil richness is achieved by adding volumes of oil already produced to the proven reserves. This number is referred to as DTD-discovered-to-date. A Maturity Index (expressed as percentage) is obtained by calculating the ratio of oil already produced to the entire DTD. The U.S. industry has discovered to date about 190 billion barrels, of which we have already produced about 166 billion (a Maturity Index of $>87$ percent). By comparison, Saudi Arabia, with DTD of 327 billion, has a Maturity Index of only 21 percent, Iraq of about 19 percent, Norway a DTD of about 16 billion and Maturity Index of about 41 percent.

Global gas reserves are also concentrated in very few areas of the world, mainly the Middle East, North America, and Russia. However, the economics of gas development are very different from those of oil. The gas business is market dependent, has very high development and transportation costs, and requires long-term contracts. As a result, gas resources are developed mainly as a function of distance to specific markets (North America, Northwest Europe, and Southeast Asia) or long-term favorable economics. Consequently, the very large Middle East resources are undeveloped. The largest present producers are the CIS with about $27 \mathrm{TCF} /$ year production and R:P ratio of 74 years; United States with $19 \mathrm{TCF} /$ year and only about 9 years remaining; Canada with about 5.5 TCF/year and 17 years R:P; and Netherlands at $3 \mathrm{TCF} /$ year production and 22 years R:P ratio. On the other hand, at present rates of production (1 TCF or less per year), the Middle East giants Iran, Iraq, Qatar, Abu Dhabi, and Saudi Arabia have reserves with hundreds of years of potential production. Development of these resources will require investment in pipelines and LNG (liquefied natural gas) projects of the order of hundreds of billions of dollars. Outside of a few specific markets, gas cannot compete with oil as a global energy source at present prices. For that reason, much of the world's natural gas reserves cannot be economically developed.

A compelling argument for increased use of gas is the environment. Gas combustion results in fewer of the pollutants that contribute to acid rain, smog, and other air quality problems. Sulfur dioxide emissions (a primary contributor to acid rain), are virtually zero. Particulate emissions are minimal; nitrogen oxide and carbon emissions are much lower; and with gas there is no waste disposal problem. Gas is not only cleaner but also provides a very efficient energy source. Gas is becoming a major source of electrical power generation for the growing economies of the world.

Most of the major oil and gas discoveries in the 1990's are being made in relatively mature, highly petroliferous basins. These include development of existing or similar plays in the same basin, new play discoveries, or technological breakthroughs such as deep-water-production technology and imaging beneath complete structures, for example. However, international oil company budgets for exploration have to compete with large-scale opportunities in improving recovery from producing fields which have opened up lately due to economic and political changes in many previously closed countries. These opportunities include both development of newly discovered, technically complex or marginally economic fields (for example, Vietnam, Azerbaijan, Timan Pechora, West Siberia, or Chevron's Tengis J.V. in Kazakhstan), and mature fields with declining production (for example, Venezuela, India, People's Republic of China, and Algeria). These abundant, lowgeologic-risk opportunities compete extensively with worldwide frontier exploration for diminishing fund ing. In making decisions for the investment of funds, all inter ational corporations compare the political, economic, and geologic risks of all ventures with their expected economic returns before making significant commitments. Outside of the U.S. Gulf of Mexico, attractive exploratory opportunities are rare or nonexistent in all areas of the United States still open to the industry. Overmaturity of domestic exploration and production, scarce frontier acreage, increasingly com changing regulations, taxation, and local polit $r s$ have forced our industry to seek growth opportunities internationally.

\section{The Gas and Oil Industry in the Year 2024- A Question of the Road Not Taken}

\author{
Reginal W. Spiller, U.S. Department of Energy, \\ Office of Fossil Energy, Washington, C.C. 20585
}

The energy choices that we make today will determine the energy situation 30 years from now. Natr 'al gas and oil will remain critical components of the energy' supply in our Nation for the foreseeable future. The United States, long a dominant producer of oil for domestic consumption, has become a mature producing region. As a result, the Nation is increasingly depending on imports from areas with more accessible oil. This paper will explore the expected impacts, issues, and changes in regards to the strategic role of energy in the United States up to the year 2024. The advanced research important to the gas and oil industry and the Nation will receive the main focus.

\section{Introduction}

In the 1970's, two major oil price incre'ses sparked a desire to develop alternative transportation fuels as insurance against petroleum shortages and high prices (Energy Information Administration, 1994). Subsequent lower 
petroleum prices, plentiful supplies, and higher costs of alternate fuels caused interest to wane. Now the United States is renewing its attention to transportation fuels that might replace gasoline and diesel fuel. The current effort is directed at improving air quality as well as increasing domestic energy security. Alternate fuels and the vehicles powered by them are viewed as ways to reduce harmful air pollutants and greenhouse gases (fig. 1).

The shift to importing more foreign oil has been significant for over 20 years, and costs for imported oil have amounted to more than 60 percent of our trade deficit (U.S. Department of Energy, 1993). Between 1980 and 1992 , the United States paid $\$ 742$ billion (1987 dollars) to other countries to purchase imported crude oil and petroleum products. In comparison, over the same period Americans paid $\$ 498$ billion for imported automobiles. In fact, oil import trends are rising. In 1992, imports accounted for 41 percent of U.S. consumption. The Energy Information Administration (EIA) projects that by 1995 or 1996 this figure will exceed 50 percent. The U.S. Office of Technology estimates that by the year 2000 , the preceding figure could rise to as high as 70 percent. These changes in the energy sector that will occur over the next 30 years will be addressed through three questions in this paper. The questions concern advanced research programs at the U.S. Department of Energy.

\section{Discussion}

Question 1. How different will gas and oil technologies be? Workstations and digital databases were around in 1979, a short time ago, but many of us may not have been fully utilizing them. When 1979 is compared to 1994, there are some dramatic changes from 15 years ago; however, many of the tools of our trade remain the same. Paper well logs, seismic sections, and some of the exploration and production methods are similar today to 30 years ago. Much work done today in the industry is based on information collected in the past. This fact can be verified with a visit to a conventional core storage warehouse, where a large amount of data will be found firmly fixed to the technology of that day.

Question 2. What are the drivers of technology? Where are dollars being spent today in R\&D? What "market pull" technologies are on the horizon? The U.S. Department of Energy is funding R\&D that is being demonstrated today and will be used in the year 2024. The Secondary Recovery Gas Project is cofunded with the Gas Research Institute (GRI) and is managed by the Bureau of Economic Geology in Austin, Texas. The nature of this project is drilling "smart wells" in fields. When geologic and engineering data are integrated with 3-D seismic surveys, fewer wells potentially extract more reserves. Three demonstration projects provided excellent results in 1993.

\section{Industry in a Changing E\&P Climate}

\section{Drivers:}

- Lack of access to capital;

- Natural gas and oil price volatility;

- Mature U.S. production from onshore regions;

- Expensive and time-consuming permitting procerses required for drilling in certain domestic areas; and

- Increased competition from cheap foreign oil.

\section{Results:}

- Increased business climate uncertainty and reduced industry profitability;

- Increased percentage of E\&P budgets spent overseas;

- Reduced RD\&D funding by the private sector;

- Decreased domestic oil production and increased oil imports;

- Decreased domestic natural gas completions; and

- Significant decreases in industry jobs.

Figure 1 (Spiller). Drivers of and results from a changir g exploration and production (E\&P) climate (U.S. Department of Energy, 1994).

Some "market pull" gas technologies are receiving great emphasis, including fuel cells, gas turbines, nat "ral gas cooling systems, natural gas lighting in hom?s and restaurants, solar power electrical ignition for natural gas street lights, and natural gas vehicles. These techrologies are all being cost-shared by the Department of Energy and industry to give an incentive to further develop our natural gas reserves.

Question 3. What is the effect of existing leg:slation, such as Clean Water Act, Clean Air Act, Resource Conservation and Recovery Act, and other related legislation on the petroleum industry; and how will these acts evolve or change? Legislation such as the Clean Air Act, Clean Water Act, and other legislation is having a major impact. on the future of the oil and gas business sectors such as exploration, production, transportation, and refining. The Nationel Petroleum Council (NPC) last year reported that the cost to refineries for complying with existing legislation was going to be $\$ 32$ billion by the year 2010 . In accordance with leg 'slation, changes that are being analyzed by industry concren discharges of fluids, tank storage, drilling waste and products, emergency response, and cooperation among industry, environmentalists, and regulators. Sound environmental programs must be developed in all phases of oil and gas exploration, production, and processing. The ef ${ }^{f_{e}}$ cts of 
legislation to the year 2024 will be felt in the business, but more cooperation between participants can reduce the impacts of the legislation.

\section{Conclusions}

The changes in the energy picture have been explored and will be significant to the year 2024. The changes are controlled by the choices we make today and in some cases by the past choices made. The energy security of the United States that the U.S. Department of Energy is promoting is being accomplished through advanced research, development, and demonstration programs. The future energy picture to the year 2024 will be shaped by our use of natural gas as an alternate fuel and the implementation of advanced technologies.

\section{Acknowledgments}

The author thanks Charles E. Brown, U.S. Department of Energy, Office of Fossil Energy, for review of this manuscript.

\section{REFERENCES}

Energy Information Administration, 1994, Altern ×ives to traditional transportation fuels-An overview: U.S. Department of Energy, DOE/EIA-0585/O, 148 p.

U.S. Department of Energy, 1993, The domestic natural gas and oil initiative-Energy leadership in the world eronomy: $36 \mathrm{p}$.

1994, Advanced computational technolory initiative, Draft report: $79 p$.

[Note: Panel members' papers were solicited to engender debate and to show differences of opinion on complex subjects of energy and the environment. The views are those of the panel members and do not reflect USGS or U.S. Government policy.] 


\section{AUTHOR INDEX}

DuChene, H.R. $\quad 98$

Abbott, M.M. 87

Ackman, T.E. $\quad 88$

Affolter, R.H. $\quad 44$

Ahlbrandt, T.S. 1

Anderson, J.E. 109

Asher-Bolinder, Sigrid

Attanasi, E.D. 10

Axon, A.G. $\quad 48$

Edenborn, H.M. $\quad 109$

Eggleston, J.R. $\quad 102,109$

Ellis, M.S.

50

Fedorko, N. 48

Fehlhaber, Kristen 68

Ferderer, D.A. $\quad 50$

Filipek, L.H. 36

Back, William 34

Bates, A.L. 82

Baedecker, M.J. 34

Bechtel, T.F. 119

Been, J.M. 98

Begay, Stephanie 118

Bernknopf, R.L. 33

Beyer, L.A. 56

Biewick, L.R.H. 50

Bird, K.J. $\quad 45,56$

Booth, J.S. 68

Bragg, L.J. $\quad 38$

Bricker, O.P. $\quad 90$

Brown, C.L. 91

Bryant, Karen 50

Byrer, C.W. 72

Finch, W.I. 111

Finkelman, R.B. $\quad 14,38,102$

Fitzpatrick, Joan 20

Flores, R.M. 58

Flug, Marshall 103

Fouch, T.D. 10

Frohne, K.H. $\quad \mathbf{7 0}$

Gardner, N.K. $\quad 48$

Gautier, D.L. $\quad 8,41$

German, M.I. 120

Geroyan, R.I. 48

Gluskoter, H.J. 12

Gough, L.P. $\quad 82$

Growitz, Douglas 109

Gundersen, L.C.S. $\quad 22,111$

Campbell, B.G. $\quad 93$

Carlson, P.R. 105

Carpenter, George 63

Carter, M.D. 48

Cetin, H. 48

Chaiken, R.F. $\quad 88$

Chapelle, F.H. $\quad 93$

Charpentier, R.C. 10

Chavez, P.S., Jr. 33

Clayton, J.L. 78

Cole, Frances 45

Coleman, D.F. 68

Collett, T.S. 68

Condon, S.M. 66

Craigg, S.D. 95

Cravotta, C.A. III 34

Crovelli, R.A. $\quad 70$

Cunningham, K.I. $\quad 66,98$

Damberger, H.H. 99

Dersch, J.S. 52

Dillon, W.P. $\quad 68$

Dolton, G.L. $\quad 8$

Isaacs, C.M. 56

Johnson, R.C. $\quad 58$

Hatch, J.R. 44

Heise, Bruce 105

Herring, J.R. 56, 82

Hettinger, R.D. $\quad 50$

Holm, M.R. 52

Holmes, C.W. 79, 82

Horton, G.W. $\quad 55$

Houseknecht, D.W. 3

Howell, D.G. 45

Huffman, A.C., Jr. 66

H

8

Keefer, W.R. $\quad 58$

Keller, M.A. 56

Kharaka, Y.K. 25

Kim, A.G. $\quad 88$

Kirschbaum, M.A. $\quad 50$ 
Kleinmann, R.L. 109

Kotra, R.K. 82

Kruger, D.W. 72

Kvenvolden, K.A. $17,68,105$

$\mathbf{L}$

Landmeyer, J.E. $\quad 93$

LaRock, E.J. 98

Larson, B.S. 66

Law, B.E. $\quad 70$

Lawson, R.L. 123

Lee, M.W. 68

Leggett, Jeremy 124

Lerch, H.E. $\quad 82$

Leventhal, J.S. $\quad 78,81$

Lillis, P.G. 56

Luoma, S.N. 91

M

Magoon, L.B. $\quad 45,56$

Manydeeds, S.A. $\quad 60$

Martin, Suzette 118

Masters, C.D. 7

Mazzella, A.T. 114

McCabe, P.J. 27

McGregor, B.A. 1

Merewether, E.A. 60

Michel, Jacqueline 107

Michmerhuizen, C.M. $\quad 84$

Molnia, C.L. $\quad 50$

$\mathbf{N}, \mathbf{O}$

Nesbitt, Dale 126

Norden, A.W. 109

Oman, C.L. 38

Orem, W.H. 82

Oremland, R.S. 17

Otton, J.K. 36, 111

Owen, D.E. 111

\section{$\mathbf{P}$}

Passmore, M.E. 109

Pavia, Robert 107

Petkewich, M.D. 93

Pierson, C.T. 111

Piper, D.Z. 56

Podwysocki, M.H. 109

Pollastro, R.M.

Price, L.C. 56

Prugh, B.J., Jr. 109

\section{$\mathbf{R}$}

Ray, P.K. 63

Reimer, G.M. $\quad 66,98,111$

Rice, D.D. $\quad 10,72,78$

Rice, K.C. $\quad 90$

Ridgley, J.L. 66
Robbins, E.I. 109

Roberts, L.N.R. $\quad 50$

Roberts, S.B. 50

Rohrbacher, T.J. 48

Ryder, R.T. $\quad 70$

SanFilipo, J.R. $\quad 75$

Schatzel, S.J. $\quad 88$

Schenk, C.J. 64

Schmoker, J.W. 10, 70

Schneidermann, Nahum

127

Schumann, R.R. 111

Semken, S.C. 118

Siskind, D.E. $\quad 88$

Sites, R.S. $\quad 48$

Smith, B.D. $\quad 60,114$

Soller, D.R. 33

Spencer, C.W. $\quad 70$

Spiker, E.C. $\quad 82$

Spiller, R.W. 128

Stanley, R.G. $\quad 56$

Stanton, M.R. 109

Stricker, G.D. $\quad 50$

Striegl, R.G. $\quad 84$

Sundquist, E.T. 16

Sutherland, W.M. 70

Sweet, P.C. 109

Szabo, Zoltan 22

Szarzi, S.L. 98

$\mathbf{T}$

Takahashi, Ken 41

Taylor, D.J. $\quad 42$

Teeters, D.D. 48

Tennyson, M.E. 56

Tewalt, S.J. $\quad 38$

Thamke, J.N. 95

Tosta, Nancy 6

Trevits, M.A. $\quad 88$

Treworgy, C.G. $\quad 48$

Turk, J.T. $\quad 30$

$\mathbf{V}, \mathbf{W}$

Vandyke, T.M. 109

Viger, R.J. 64

Wanty, R.B. 25, 72

Warwick, P.D. 75

Watson, W.D. $\quad 50$

Weintraub, V.C. 82

Weisenfluh, G.A. $\quad 48$

Wilshire, H.G. 117

Winters, W.J. 68

Zech, R.S. 66

Zielinski, R.A. 111

Zihlman, F.N. 42 


\section{U.S. GEOLOGICAL SURVEY}

ORGANIZATION

Director - Gordon Eaton

703-648-7411

Associate Director, Programs

Bonnie McGregor 703-648-7412

Associate Director, Operations

Barbara Ryan 703-648-7430

Water Resources Division

Chief Hydrologist

Robert Hirsch

703-648-5215

Geologic Division

Chief Geologist, John Filson,

Acting 703-648-6600

National Mapping Division

Allen Watkins, Chief 703-648-5747

Support Services

Administrative

William Gossman, Acting

703-648-7200

Information Systems

Wendy Budd, Acting

703-648-7108

Human Resources Office

Lynn Smith 703-648-7111
ISSUES

CONTACTS

\section{RESOURCES}

Energy - David Houseknecht 703-648-6470

Minerals - Will White 703-648-6100

Water - Robert Hirsch 703-648-5215

HAZARDS

Earthquakes, Volcanoes, Landslides

Robert Hamilton 703-648-6714

Floods - Verne Schneider 703-648-5229

\section{ENVIRONMENT}

Critical Ecosystems - Sarah Gerould 703-648-445C

Global Change - Michael Carr 703-648-4450

Toxic Substances Hydrology

Tim Miller 703-648-6868

Remote Sensing - Donald Lauer 605-594-6123

Ground Water - William Alley 703-648-5035

Surface Water - Verne Schneider 703-648-5229

National Water Quality Assessment

Patrick Leahy 703-648-5012

Abandoned Mine Lands

Energy - David Houseknecht 703-648-6470

Minerals - Will White 703-648-6100

Hydrology - Tim Miller 703-648-6868

Center for Environmental Geochemistry and

Geophysics - Larry Gough 303-236-3301

\section{INFORMATION/DATA MANAGEMENT}

Internet: using a World Wide Web browser, the URL is HTTP:IUNFO.ER.USGS.GOV

Maps and Publications 1-800-USA-MAPS

Mapping/GIS/Land Cover

Allen Watkins 703-648-5747

Water - James Biesecker 703-648-6858

Geologic Mapping - John Sutter 703-648-6960

Public Affairs/News Releases

Donovan Kelly 703-648-4460

Electronic Data Management

Eliot Christian 703-648-7245

Strategic Planning/Theme Coordination Gary Hill, Acting 703-648-4450 


\section{ADDRESSES}

U.S. Geological Survey

National Center

12201 Sunrise Valley Drive

Reston, VA 22092

U.S. Geological Survey

Branch of Alaskan Geology

4200 University Drive

Anchorage, AK 99508-4667

U.S. Geological Survey

Hawaiian Volcano Observatory

Hawaii National Park

HI 96718
U.S. Geological Survey

Box 25046

Denver Federal Center

Denver, CO 80225

U.S. Geological Survey 2255 North Gemini Drive Flagstaff, AZ 86001

U.S. Geological Survey

David A. Johnston Cascades

Volcano Observatory

5400 MacArthur Boulevard

Vancouver, WA 98661
U.S. Geologic 1 Survey 345 Middlefie'd Road

Menlo Park, CA 94025

U.S. Geologic ^l Survey 384 Woods Hole Road Woods Hole, MA 02543-1598

U.S. Geological Survey 600 4th Street. South

St. Petersburg. FL 33701

Manuscript approved for publication November 10, 1994

Published in the Central Region, Denver, Colorado

Photocomposition by Shelly A. Fields

Drafting by authors and by Carol A. Quesenberry

Final graphics preparation by Carol A. Quesenberry 
